UNIVERSIDADE DE SÃo PAULO

FACULDADE DE DIREITO

O Neoconstitucionalismo e O FIM do ESTAdo de DiREITo

Jorge OCtávio Lavocat Galvão

São Paulo

2012 


\section{O NEOCONSTITUCiONALISMo E O FIM DO ESTAdo DE DiREITO}

Tese de doutorado apresentada como requisito parcial para a conclusão do curso de Doutorado em Direito, Área Direito do Estado, Subárea Direito Constitucional, sob orientação do Prof. Titular Manoel Gonçalves Ferreira Filho

São Paulo - SP

Faculdade de Direito da USP 
Nome: Jorge Octávio Lavocat Galvão

Título: O Neoconstitucionalismo e o fim do Estado de Direito

Tese defendida em de de 2012, perante banca examinadora composta pelos professores:

Prof. Titular Manoel Gonçalves Ferreira Filho - Orientador

Membro

Membro

Membro

Membro 


\section{Resumo}

Na última década emergiu na academia brasileira um movimento doutrinário denominado Neoconstitucionalismo, que advoga a adoção de uma série de posturas interpretativas que conferem maior liberdade aos juízes ao decidirem os casos constitucionais no intuito de promover transformação social pelo Direito. A partir de uma reconstrução interpretativa do ideal político Estado de Direito, procura-se avaliar o impacto das teses defendidas pelo modelo decisório neoconstitucionalista, concluindo-se que nas sociedades democráticas contemporâneas, em que há profundos desacordos morais, a sua adoção é inadequada por implicar violações à dignidade humana.

Palavras-chaves: Neoconstitucionalismo, Estado de Direito, transformação social, dignidade humana. 


\begin{abstract}
In the last decade, a legal movement known as neoconstitutionalism has emerged in the Brazilian legal academy. It advocates the adoption of a series of interpretative attitudes which confer a wide margin of discretion to judges when deciding constitutional cases with the aim of achieving social transformation through law. Relying on a reconstructive interpretation of the Rule of Law political ideal, this work aims to assess the impacts of the thesis defended by the neoconstitutionalist adjudicative model. It concludes, at the end, that in contemporary democratic societies, where people deeply disagree on moral regards, the adoption of neoconstitucionalism is inadequate in virtue of the violations it infringes upon human dignity.
\end{abstract}

Key words: Neoconstitutionalism, Rule of Law, social transformation, human dignity. 
À Cris, amor da minha vida. 


\section{Agradecimentos}

"Não é preciso ter vários heróis se você os escolhe cuidadosamente" escreveu John Hart Ely ao dedicar a sua obra Democracy and Distrust ao Chief Justice Earl Warren. Se seguisse à risca o conselho de Ely e tentasse ser mais seletivo, eu não faria justiça às grandes figuras com quem tive a sorte de me relacionar durante minha vida acadêmica e que influenciaram decisivamente no meu modo de enxergar o Direito.

Logo na graduação em Direito na Universidade de Brasília (UnB), há quase uma década, tive a honra de ser aluno do Professor Gilmar Ferreira Mendes. Sua dedicação, conhecimento e preocupação com as questões de direito constitucional me sensibilizaram, nascendo daí o meu especial interesse pela pesquisa o por esse ramo do conhecimento jurídico.

Mais adiante, durante o meu mestrado na Universidade de Nova Iorque (NYU), tive a oportunidade de estudar com os Professores Jeremy Waldron e Ronald Dworkin. Se Dworkin já me era familiar dos livros, Waldron foi uma das mais gratas surpresas que tive na academia. Sua percepção aguçada e sua argumentação implacável ajudaram-me a compreender as intrincadas interfaces entre direito e moral, constitucionalismo e democracia. A influência de ambos é latente em meu trabalho.

Já no doutorado na Universidade de São Paulo (USP), encontrei nos Professores Manoel Gonçalves Ferreira Filho e José Levi Mello do Amaral Júnior a certeza de que minhas angústias quanto à jurisdição constitucional brasileira tinham fundamento. Se antes eu tinha a percepção de que as questões de direito constitucional não poderiam se resumir a problemas de interpretação constitucional, após o contato com esses mestres que tanto prezam pelo estudo dos arranjos políticos democráticos, tive a convicção de estar no caminho certo.

Complementando, tenho o orgulho de mencionar o Professor Luís Roberto Barroso, com quem tive a felicidade de ter contato mais próximo nos últimos anos. Passei a admirá-lo não apenas por ser um acadêmico de primeira linha, mas também pelo fino trato com que recebe os amigos e alunos. A forma elegante como aborda temas complexos e expõe suas ideias e ideais é inspiradora. Tenho a certeza de que compreenderá que as críticas aqui formuladas representam um reconhecimento da importância de seu trabalho e que nossas divergências são meramente teóricas. 
A todos, meu muito obrigado!

Sou grato também a outras pessoas que contribuíram de forma importante para a conclusão deste doutorado. Primeiramente à minha família, que sempre me apoiou nos projetos acadêmicos, ainda que isso tenha representado um tempo menor de convívio. Sem o incentivo irrestrito de minha mãe, nada teria sido possível. Sem o reconhecimento de meu pai, nada teria valor.

Agradeço, finalmente, à Procuradoria-Geral do Distrito Federal, que acreditou na seriedade do projeto e acatou meu pedido de afastamento para estudos, viabilizando o tempo necessário para dedicar-me à pesquisa, e à Universidade de Yale, que gentilmente me acolheu como Pesquisador Visitante e colocou toda a infraestrutura da Faculdade de Direito à minha disposição. 


\section{Sumário}

Introdução

I. A persistência de desacordos e a necessidade de coordenação em uma sociedade plural .....

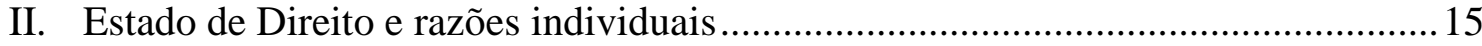

III. O Neoconstitucionalismo e o "fim" do Estado de Direito ......................................223

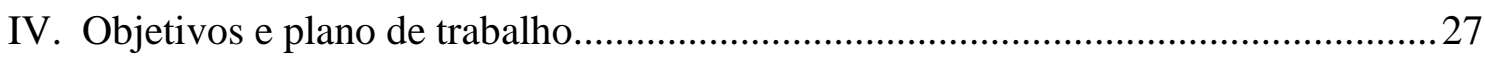

Capítulo 1 - A alma do Neoconstitucionalismo: inspiração e enquadramento no debate

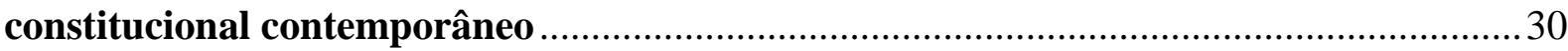

1.1 - Considerações iniciais: conceito e essência ........................................................... 30

1.1.1 - A difícil tarefa de definir Neoconstitucionalismo ......................................... 32

1.1.2 - A essência do Neoconstitucionalismo .......................................................... 35

1.2 - Transformação social e judicial review............................................................ 38

1.2.1 - O Realismo Jurídico e a construção jurídica do modelo Brown ..................... 45

1.3 - O controle de constitucionalidade e a questão da legitimidade ............................ 48

1.3.1 - O argumento da vontade popular ..................................................................50

1.3.2 - $\mathrm{O}$ argumento da competência funcional ....................................................52

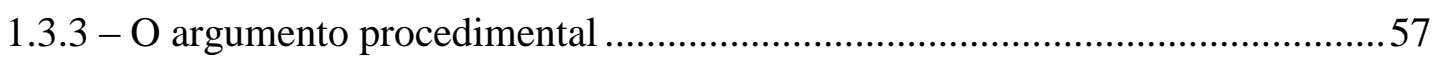

1.3.4 - O argumento da proteção de direitos............................................................. 60

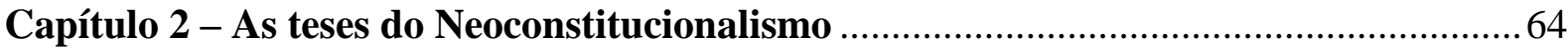

2.1 - Efeitos do Neoconstitucionalismo: a constitucionalização do Direito.................... 64

2.2 - Eduardo Ribeiro Moreira e a "Invasão da Constituição" .......................................65

2.3 - Luís Roberto Barroso e o "Triunfo Tardio do Direito Constitucional” ..................69

2.4 - Antônio Cavalcanti Maia e “As Transformações dos Sistemas Jurídicos

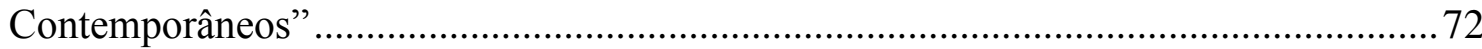

2.5 - Daniel Sarmento e a "Ubiquidade Constitucional”................................................. 74

Capítulo 3 - Neoconstitucionalismo como concepção jurídica .......................................... 80

3.1 - Neoconstitucionalismo: mera descrição de um paradigma? ................................... 80

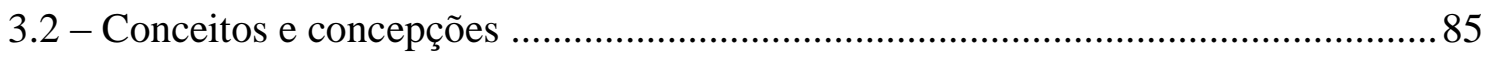

3.3 - O Direito como um conceito interpretativo .................................................... 92 


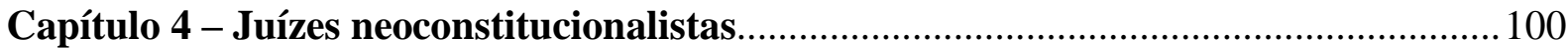

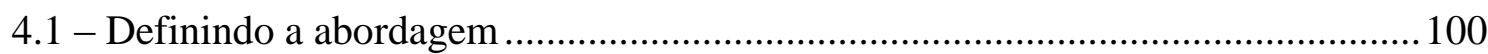

4.2 - Permanência e mudança no Neoconstitucionalismo ............................................... 101

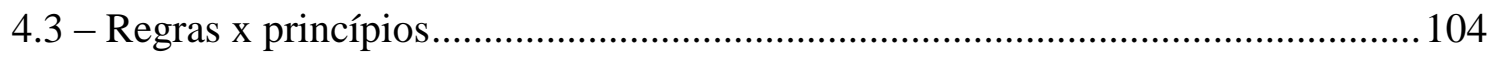

4.4 - Direitos fundamentais: argumentos de princípio e de política no

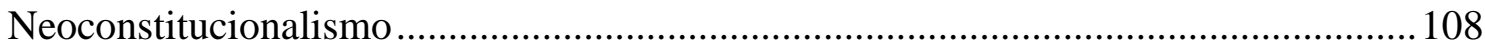

4.5 - Ponderação: o papel das razões jurídicas no Neoconstitucionalismo …………..... 115

4.6 - Neoconstitucionalismo: uma espécie de pragmatismo jurídico? ........................... 131

Capítulo 5 - Reconstruindo o Estado de Direito ………………………………………...... 135

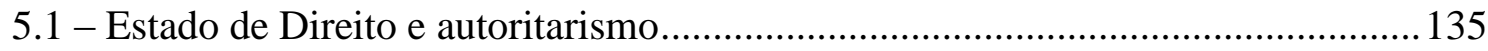

5.2 - Estado Democrático de Direito e constitucionalismo dirigente .............................. 137

5.3 - Estado de Direito e democracia.......................................................................... 141

5.4 - Desacordos, regra da maioria e Estado de Direito: a dignidade da legislação..... 143

Capítulo 6 - A dignidade do Estado de Direito ………………………………………..... 151

6.1 - Três temas associados ao Estado de Direito …………………………………...... 151

6.2 - Concepções formais e substantivas de Estado de Direito ........................................153

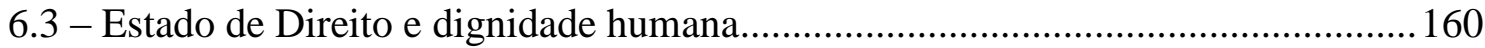

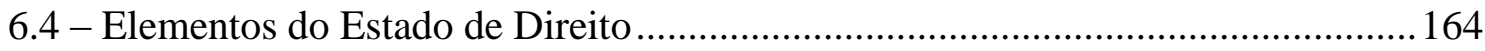

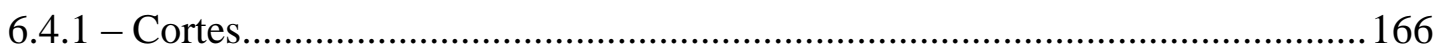

6.4.2 - Normas gerais e públicas.......................................................................... 167

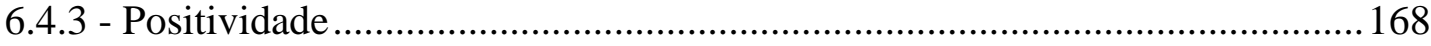

6.4.4 - Orientação para o bem comum..................................................................... 169

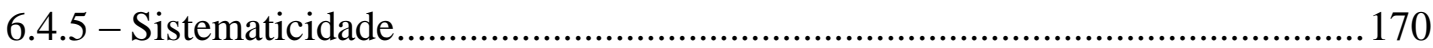

Capítulo 7 - Estado de Direito e Neoconstitucionalismo: tensões e contradições ...........173

7.1 - Diagnosticando as contradições .......................................................................... 173

7.2 - O Neoconstitucionalismo e a função das normas jurídicas.....................................175

7.3 - Neoconstitucionalismo e interpretação constitucional............................................181

7.4 - Estado de Direito e jurisdição constitucional: uma Constituição modesta ...........190

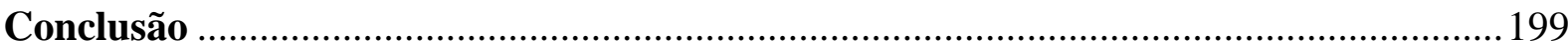

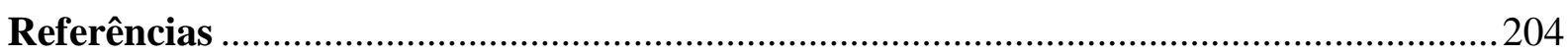




\section{Introdução}

\section{A persistência de desacordos e a necessidade de coordenação em uma sociedade plural}

O preâmbulo da Declaração Universal dos Direitos Humanos de 1948 da Assembleia Geral da Organização das Nações Unidas (ONU) enuncia: "Para que o homem não seja compelido, como último recurso, à rebelião contra a tirania e a opressão, considera-se essencial que os direitos humanos sejam protegidos pelo Estado de Direito”. A Constituição Federal de 1988 também se vincula expressamente a este ideal político ao preceituar no caput de seu primeiro artigo que: "A República Federativa do Brasil (...) constitui-se em $\underline{\text { Estado }}$

\section{democrático de direito"}

Há, atualmente, quase um consenso global da necessidade de se respeitar o Estado de Direito para que se considere um governo legítimo. Mas, afinal, o que há de especial na coordenação da vida em sociedade por meio de um ordenamento normativo previamente estabelecido? Em outras palavras, o que torna o Estado de Direito um ideal político venerado? A limitação do poder dos agentes públicos e a necessidade de previsibilidade em relação às consequências jurídicas decorrentes das condutas dos indivíduos são respostas imediatas. Uma análise conceitual um pouco mais elaborada, no entanto, parece nos indicar que o que faz do Estado de Direito um valor político atrativo nas sociedades contemporâneas é o modo digno pelo qual as instituições públicas se apresentam aos cidadãos. Para uma compreensão dessa afirmativa torna-se necessário esclarecer alguns pressupostos.

Vive-se em uma sociedade notadamente marcada pela pluralidade de visões de mundo $^{1}$. No Brasil, da mesma forma como nas demais democracias constitucionais, não há perspectiva de consenso entre os cidadãos sobre temas de grande relevância para a sociedade. Muito pelo contrário, as pessoas normalmente divergem sobre caros aspectos da experiência

\footnotetext{
${ }^{1}$ Rawls assim define essa faceta das sociedades contemporâneas: "A diversidade de doutrinas religiosas, filosóficas e morais existentes em sociedades democráticas modernas não é uma mera condição histórica que logo passará; é um aspecto permanente da cultura pública de uma democracia. Nas condições políticas e sociais garantidas pelos direitos e liberdades básicos de instituições livres, pode surgir e perdurar uma grande diversidade de doutrinas abrangentes conflitantes e irreconciliáveis, mas razoáveis, caso já não existissem. É esse fato das sociedades livres que denomino fato do pluralismo razoável". (RAWLS, 2003, p. 47).
} 
humana, discordando das soluções adotadas até mesmo em questões de menor importância. Dois tipos de desacordos são particularmente importantes para os estudiosos do direito constitucional.

Em primeiro plano, não há entendimento acerca do que deva ser considerada uma vida boa. Enquanto uns acreditam, por exemplo, que a devoção religiosa traz satisfação pessoal, outros veem na realização profissional ou na acumulação de riqueza o seu objetivo de vida. Há desacordos sobre o papel da família, a vida sexual, a importância dos estudos etc. Questões relacionadas às diversas concepções morais existentes levam invariavelmente a debates acalorados. A utilização de métodos contraceptivos, o suicídio assistido e o casamento entre pessoas do mesmo sexo, entre outros, são temas que frequentemente provocam discordância entre os membros da sociedade. Que direitos morais temos? Que significa a liberdade em contextos complexos como os que envolvem, por exemplo, a publicação de discursos preconceituosos? O aborto deve ser considerado uma opção legítima dentro da perspectiva da igualdade de controle de oportunidades entre homens e mulheres?

Em segundo plano, há profundas divergências com relação ao modo como as riquezas devam ser distribuídas numa sociedade justa e quanto ao papel do Estado nessa distribuição. Alguns acham que a alocação dos bens deveria ser realizada de acordo com os méritos de cada um, enquanto outros entendem que a igualdade material seria o principal objetivo a ser alcançado. O grau de intervenção na economia e o papel da religião no Estado também são insistentemente abordados pelas diversas correntes políticas. Em virtude dessas diferentes concepções de justiça, questões referentes às ações afirmativas, à utilização de ícones religiosos em repartições públicas e aos programas de redistribuição de renda, e.g., não encontram respostas unívocas. Uma teoria constitucional contemporânea precisa encarar o fato de que, mesmo acreditando na existência de direitos e da justiça, as pessoas discordam apaixonadamente sobre o seu significado e suas implicâncias nas situações concretas. Não há um repositório moral amplamente compartilhado que possa ser consultado para a resolução dos conflitos que permeiam a sociedade.

Não obstante as múltiplas concepções morais e políticas - que por vezes se mostram conflitantes e irreconciliáveis - a vida em sociedade se apresenta como um empreendimento coletivo que demanda a cooperação entre os indivíduos. A proteção ao meio ambiente, o funcionamento de um sistema público de saúde e a prestação de jurisdição são exemplos de atividades essenciais que somente se mostram realizáveis se as pessoas atuarem em grupo. Por mais que haja desacordos sobre a melhor forma de se preservar o ecossistema, de se tratar as diversas enfermidades ou de se aparelhar o Poder Judiciário, revela-se necessário 
estabelecer uma estrutura institucional única que possibilite o agir coletivo. Por óbvio, essa atuação em conjunto não é algo fácil, sobretudo se se considerar que a adoção de determinado ato normalmente vai de encontro às convicções de uma parcela dos cidadãos que discordam de seu conteúdo. Nesse sentido, a capacidade de agir coletivamente por si só já se apresenta como uma conquista humana. Essa necessidade de se decidir uma série de questões, a despeito de haver uma realidade social marcadamente dividida, configura o que Jeremy Waldron denomina de circunstâncias da política ${ }^{2}$.

A forma como essas decisões são tomadas em uma sociedade plural é determinante para se aferir a legitimidade do regime político em questão. O tratamento com igual respeito e consideração a todos os cidadãos conduz inexoravelmente ao estabelecimento de procedimentos decisórios que sejam substancialmente neutros com relação às diversas concepções morais e políticas existentes ${ }^{3}$. Isso porque o comprometimento a priori com qualquer resultado implicaria no reconhecimento de que um determinado ponto de vista defendido por uma pessoa ou um grupo é superior ao dos demais, o que se revela incompatível com as ideias de igualdade de participação e de capacidade de autodeterminação.

Estando as instituições públicas funcionando de maneira adequada ${ }^{4}$, o mecanismo por excelência pelo qual a sociedade define o seu agir coletivo é o processo político democrático. Nesse modelo, após a manifestação das razões que animam as diferentes visões de mundo sobre um determinado tema, decide-se a questão - diretamente ou por representantes - através da adoção da solução que a maioria entende ser a mais adequada naquelas circunstâncias. É por meio da regra da maioria, portanto, que são editados os principais atos normativos - como a Constituição e as leis ordinárias - em uma sociedade que se importa em tratar os seus cidadãos de forma legítima. Somente contando os votos de todos é possível dar tratamento igualitário aos diferentes pontos de vista.

\footnotetext{
${ }^{2}$ WALDRON, 1999, p. 101-103.

${ }^{3}$ Trata-se da virtude política denominada por Ronald Dworkin como "equidade". Segundo o autor norteamericano: "Fairness in politics is a matter of finding political procedures - methods of electing officials and making their decisions responsive to the electorate - that distribute political power in the right way. That is now generally understood, in the United States and Britain at least, to mean procedures and practices that give citizens more or less equal influence in the decisions that govern them". (DWORKIN, 1986, 164-165).

${ }^{4}$ Waldron (2010, p. 106) afirma que o processo político tradicional é o método adequado de tomada de decisão nas sociedades que possuam "(1) instituições democráticas em condições de funcionamento razoavelmente boas, incluindo um legislativo representativo, eleito por sufrágio adulto universal; (2) um conjunto de instituições judiciais, também em boas condições de funcionamento, erigidas sobre uma base não representativa para conhecer de ações individuais, resolver controvérsias e defender o Estado de direito; (3) um comprometimento da parte da maioria dos membros da sociedade e da maioria de suas autoridades com a ideia de direitos individuais de minoria e (4) discordância persistente, substancial e de boa-fé quanto a direitos (isto é, quanto ao que realmente significa o comprometimento com direitos e quais são suas implicações) entre os membros da sociedade que estão comprometidos com a ideia de direitos".
} 
Não se quer dizer, contudo, que o processo de deliberação política seja algo neutro, uma busca pela verdade absoluta. Muito pelo contrário; ele é condicionado ao seu momento histórico, fruto da experiência de seus membros, refletindo suas vitórias e seus fracassos. Não por outro motivo é possível compreender o sentido de determinadas normas legais a partir da reconstrução dos fatos que ensejaram a sua promulgação. A décima terceira, a décima quarta e a décima quinta emendas constitucionais norte-americanas - abolindo a escravidão, declarando a igualdade entre os cidadãos e concebendo o sufrágio adulto universal, respectivamente - foram editadas logo após a Guerra Civil americana ocorrida no século XIX entre os Estados do Sul escravocratas e os Estados do Norte abolicionistas, sendo o seu conteúdo - reconhecimento de direitos civis aos negros - relacionado à derrota dos sulistas 5 . No Brasil, após o bruto assassinato da atriz Daniella Perez em 1992, o Congresso Nacional, a partir de proposta de lei de iniciativa popular - em que foram colhidas mais de 1 (um) milhão de assinaturas - alterou a Lei $\mathrm{n}^{\circ}$. 8.072/90 para incluir o homicídio qualificado na lista dos crimes hediondos ${ }^{6}$. Tais atos normativos, por serem frutos de momentos políticos marcantes, evidenciam o caráter eminentemente contingencial da legislação como fonte do Direito.

Também não se está desconsiderando que determinados atores políticos possuem uma maior influência na elaboração e no refinamento das diferentes versões sobre os temas em ebulição na sociedade. As eleições presidenciais normalmente antecipam e canalizam os debates públicos vindouros, e o Poder Executivo historicamente tem sido o principal vetor de transformações sociais que, em última instância, modificam a compreensão do compromisso constitucional e acarretam novas decisões políticas ${ }^{7}$. Esse protagonismo de líderes políticos, entretanto, não significa a subversão do processo político, pois não confere maior peso ao

\footnotetext{
${ }^{5}$ Nesse sentido, Erwin Chemerinsky (2006, p. 668) explica: "After the completion of the Civil War, in 1865, Congress enacted and the states ratified the Thirteenth Amendment, which prohibits slavery and involuntary servitude. Yet, it was obvious that the Thirteenth Amendment would not only by itself secure the rights of the former slaves; Southern states systematically discriminated against blacks in every imaginable way. Congress therefore approved and States ratified the Fourteenth Amendment in 1868. Section 1 of the Fourteenth Amendment overrules the Dread Scott decision by declaring that all persons 'born or naturalized in the United States... are citizens of the United States and of the State wherein they reside'. Section 1 also guarantees that no state shall deprive any citizen of the privileges or immunities of citizenship, or deprive any person of life, liberty, or property without due process of law, or deny any person 'equal protection of the laws "'.

${ }^{6}$ Sobre o caso Daniela Perez e a trajetória da mudança na lei penal, cf. PEREZ, Glória. Daniella Perez: Arquivos de um processo. Disponível em: www.gloriafperez.net. Acesso em: 22 de maio de 2012.

${ }^{7}$ Segundo Bruce Ackerman (2007, p. 1762-1763), a todo instante há inúmeros movimentos sociais reivindicando que sua agenda ingresse no centro dos debates políticos nacionais. A maioria desses movimentos falha, mas ocasionalmente alguma instituição governamental adota a agenda política de um deles, compelindo uma maior atenção sobre o tema no espectro político. Esse sinal institucional inaugura o que Ackerman denomina de exercício de política constitucional, em que os partidários e os contrários ao movimento mobilizam a opinião pública para confrontar as suas agendas. De acordo com o Professor de Yale, nos Estados Unidos, a função de sinalização de mudança constitucional tem sido tipicamente desempenhada pelo Presidente, acompanhado em seguida por seu partido político.
} 
voto de qualquer cidadão. Ademais, em regimes democráticos sérios, normalmente são criados mecanismos para impedir a perpetuação de uma pessoa ou um grupo no poder, como, por exemplo, proibindo-se reiteradas reeleições e exigindo-se que candidatos se afastem de cargos políticos com alguma antecedência do pleito.

Um ponto, contudo, precisa ficar claro: as leis não dissipam a existência de discordância moral sobre determinado tema. $\mathrm{O}$ fato de ter-se chegado a um determinado resultado político não significa que há um consenso na sociedade sobre o assunto. As diferentes concepções continuarão povoando a mentalidade das pessoas, e os desacordos sobre temas fundamentais persistirão. Os que se saíram perdedores no processo democrático, no entanto, respeitam a decisão da maioria por estarem cientes de que há necessidade de se tomar uma posição em nome da sociedade e que a unidade de entendimento sobre o tema é um ideal absolutamente impossível. Em outras palavras, a edição de determinado ato normativo não tem a pretensão de camuflar a existência de divergências sobre o tema na sociedade, mas apenas de definir o agir coletivo em uma situação de dissenso. O jogo democrático revela-se, então, como a forma menos gravosa pela qual uma questão controvertida é decidida, na medida em que, além de permitir a expressão de todos os pontos de vista sem privilegiar a posição de qualquer um, possibilita que, no futuro, a partir de mudanças no quadro político, econômico ou social, os atuais perdedores ganhem apoio suficiente para modificar o entendimento coletivo sobre o assunto ${ }^{8}$.

\section{Estado de Direito e razões individuais}

Ao se editar uma norma jurídica em uma sociedade plural por meio de uma decisão emanada do processo democrático, estabelece-se uma relação de compromisso mútuo entre o Estado e os indivíduos. Ao mesmo tempo em que não é facultado àquele modificar seu entendimento sobre determinado tema sem submetê-lo ao trâmite político, aos indivíduos é exigido o dever de observância ao que foi decidido pela maioria, independentemente dos pontos de vista pessoais. Esse esquema, entretanto, não deve ser entendido como forma de

\footnotetext{
${ }^{8}$ Carl Schmitt (1977, p. 43-44) já enfatizava que o que garante a legitimidade de um Estado legal é a adoção de igualdade de chances para se alcançar a maioria, vedando-se qualquer tentativa de limitar o debate público ou de impedir que determinados pontos de vista sejam banidos. Segundo o autor alemão: "Sin este principio, las matemáticas de las mayorías, con su indiferencia frente al contenido del resultado, no solo serían um juego grotesco y un insolente escarnio de toda justicia, sino que, a causa del concepto de legalidad derivado de dichas matemáticas, estas acabarían también com el sistema misto, desde el instante em que se ganara la primera mayoría, pues esta primera mayoría se instituiría enseguida legalmente como poder permanente. La igualdade de chance aberta a todos no puede separarse mentalmente del Estado legislativo parlamentário. Dicha igualdad permanece como el principio de justicia y como uma condición para la autoconservación".
} 
opressão de uma minoria que saiu perdedora nas urnas, mas como possibilidade de agir coletivamente em uma situação de dissenso. A menos que uma parcela da população saia sistematicamente vencida, seja por vício do processo ou por discriminação, considera-se que a política, como forma de tomada de decisões, trata os indivíduos com dignidade. O que precisa ficar claro é que aparentemente não há alternativa: caso fosse permitido a todos agirem conforme suas próprias razões, seria impossível harmonizar as diversas condutas face ao pluralismo razoável existente. Haveria a anarquia. Por outro lado, caso alguém pudesse fazer prevalecer suas razões por outro meio que não a política majoritária haveria não a democracia, mas a ditadura.

A compreensão do que torna o Estado de Direito um ideal político atrativo exige exatamente a explicitação das virtudes inerentes à gerência da vida coletiva por meio de um ordenamento jurídico que justifique a resignação do cidadão ao deparar com normas contrárias às suas convicções ou interesses. Um saldo positivo nessa análise de custo/benefício está ligado à demonstração de que os cidadãos consideram-se respeitados ao utilizarem as normas jurídicas como medium para resolução de seus problemas cotidianos, independentemente do resultado final dos litígios. Essa conclusão demanda um avanço na construção conceitual sobre o tema, já que o mero apontamento das credenciais democráticas da legislação não encerra a discussão sobre o modo como o Direito é aplicado em uma sociedade. Isso porque o conceito de democracia, apesar de sua estreita relação, não se confunde com o de Estado de Direito ${ }^{9}$. Enquanto o primeiro relaciona-se ao processo político de tomada de decisões e criação de normas jurídicas, o segundo diz respeito à administração dessas mesmas normas por parte dos membros da sociedade.

Conforme mencionado, nas sociedades democráticas contemporâneas, uma das razões que confere autoridade às normas jurídicas - produtos do processo político - reside na possibilidade de coordenação das condutas humanas em uma realidade marcada pelo dissenso. Como cada indivíduo possui uma experiência única e um caráter distinto, suas razões em inúmeras circunstâncias diferem das dos demais sujeitos, o que, sem um mínimo de organização, inviabilizaria a vida em coletividade. O mecanismo mediante o qual as normas jurídicas realizam essa tarefa é essencial para se compreender a ideia de Estado de Direito.

\footnotetext{
${ }^{9}$ O Estado de Direito, assim como qualquer outro conceito político abstrato, não é unívoco, possuindo várias acepções a depender do viés utilizado por determinado autor. Há concepções formais e materiais, a depender de sua vinculação, ou não, à promoção de determinados fins específicos, como direitos humanos ou eficiência econômica. Pelas razões que serão apresentadas no momento apropriado, será adotada neste trabalho uma concepção formal elaborada a partir da obra de Jeremy Waldron, na qual se defende que a utilização do Direito como meio de resolução de conflitos já possui um significado moral intrínseco, independentemente dos valores protegidos pelo ordenamento.
} 
Um dos autores que melhor compreenderam e exploraram conceitualmente o funcionamento do Direito foi Joseph Raz. Em sua visão, as normas jurídicas exercem uma função diferenciada na formação da razão prática, influenciando de maneira decisiva a conduta das pessoas. Para elaborar o seu argumento, Raz (1999, p. 39-45) distingue o papel das razões de primeira ordem, que são as razões que alimentam as visões pessoais de cada um, como e.g. razões de prudência, de bem-estar e de moralidade, das razões de segunda ordem, consubstanciadas em razões que dizem respeito às próprias razões, excluindo da formação do juízo algumas das razões de primeira ordem.

De acordo com o Professor de Oxford, nas situações ordinárias, um agente, ao deparar com um problema, valora as diversas razões de primeira ordem antes de decidir como agir. Havendo um conflito entre essas razões, prevalece o argumento mais convincente, fazendo com que o sujeito tome a decisão que entenda ser a mais correta considerando todo o quadro existente. No entanto, em um cenário em que há uma razão de segunda ordem, a lógica difere. Isso porque as razões de segunda ordem possuem preferência em relação às de primeira ordem, excluindo as razões pessoais. Entenda-se, as razões de segunda ordem não competem com as de primeira ordem na formação da vontade, não sendo possível fazer-se um juízo de ponderação entre os dois tipos de razão envolvidos em uma tomada de decisão. Não há como medir forças entre as duas espécies de razão. As razões de segunda ordem sempre prevalecem por estarem em um patamar mais elevado, indicando, de antemão, a solução que deve ser adotada, evitando-se erros de cálculo por parte do agente. As razões de segunda ordem, portanto, reclamam ter autoridade.

Segundo Raz, dois são os motivos que conferem às razões de segunda ordem preferência na formação do juízo. Primeiro, a crença de que, se observadas as razões de segunda ordem, as decisões serão melhores do que se o sujeito pretendesse agir conforme suas próprias razões. Segundo, a economia de tempo e de esforço por parte do sujeito que, ao deparar com um problema que requer uma decisão sua, se utiliza da solução preestabelecida por alguém que possui autoridade ${ }^{10}$.

Os exemplos mais comuns relacionados à utilização de razões de segunda ordem dizem respeito à expertise de determinados sujeitos. No direito brasileiro, por exemplo, afirma-se que, tendo em vista o caráter eminentemente técnico das decisões das agências reguladoras, não cabe ao Poder Judiciário analisar o mérito de seus atos, mas apenas sua

10 Raz (1999, p. 59) esclarece esse ponto da seguinte forma: "The rule states what is to be done in these situations on the balance of foreseeable reasons. When a situation to which it applies actually occurs the norm subjects can rely on the rule, thus saving much time and labor and reducing the risks of a mistaken calculation which is involved in examining afresh each situation on its merits". 
legalidade ${ }^{11}$. Nesse contexto, por mais que o juiz tenha uma opinião sobre o tema tratado pela agência e esteja extremamente convencido de seu ponto de vista, ele não leva em consideração suas razões, prestando deferência ao órgão especializado. Mas também há outras hipóteses que surgem no contexto de ordem hierarquizada. Um agente militar, por exemplo, ao receber uma ordem de seu superior para levar uma autoridade diplomática à sua embaixada obedecendo a determinado trajeto, cumpre o que lhe foi designado, por mais que tenha plena convicção de que se adotasse outro percurso chegaria ao mesmo destino mais rapidamente ou com mais segurança. Nesses casos, por mais que as pessoas tenham uma opinião sobre como agir, suas razões pessoais são excluídas de seu juízo final por deferência ao superior.

Para Joseph Raz, as normas jurídicas são uma hipótese especial de razões de segunda ordem que atuam excluindo as razões de primeira ordem nas situações de sua incidência. Com a criação do aparato normativo do Direito, torna-se desnecessário rediscutir todos os aspectos políticos e morais que são pertinentes aos casos que se apresentam cotidianamente ao Judiciário, dado que as normas jurídicas já anteveem as hipóteses do mundo dos fatos e prescrevem, de antemão, seus resultados. Por esse motivo, as normas são, na verdade, motivos/razões para as ações humanas: ao guiar sua conduta, o indivíduo obedece às normas de maneira automática, sem questionar seu mérito ${ }^{12}$.

O condutor de um veículo, por exemplo, mantém-se na faixa da direita por uma questão de coordenação: possibilitar a continuidade do tráfego viário na comunidade. Ao agir dessa forma, o indivíduo não se questiona qual é a melhor opção para chegar a seu destino - se utilizando a pista da esquerda ou a da direita - mas simplesmente cumpre aquilo que está prescrito na norma legal. Tal questão (andar pela faixa da direita) foi de antemão decidida pelo Direito por meio de suas normas, não exigindo que o intérprete reflita sobre o tema novamente, todas as vezes que dirija seu veículo.

Com relação ao Direito, ao contrário dos exemplos ligados à expertise, o que lhe confere autoridade é exatamente a possibilidade de coordenação legítima das condutas em uma sociedade plural $^{13}$. As normas jurídicas, compreendidas como razões de segunda ordem,

\footnotetext{
${ }^{11}$ Nesse sentido, por exemplo, é a lição de Justen Filho (2002, p. 591), para quem: "Em grande parte dos casos, a atividade das agências refletirá conhecimentos técnico-científicos e atuação de especialistas. Os juízos e avaliações em que se fundam as decisões das agências poderão exteriorizar um conhecimento especializado dificilmente acessível ao funcionamento comum e normal do Poder Judiciário, cuja renovação via judicial seja extremamente problemática".

12 RAZ, 2009, p. 216-219.

${ }^{13}$ Waldron (1999, 129-138), no entanto, parece sugerir que, a par do aspecto relacionado à coordenação, a decisão da maioria teria autoridade também por expertise, já que a sua decisão seria sempre superior à de indivíduos isolados. O autor utiliza três argumentos para defender sua tese: i) o utilitarismo mostra que a melhor decisão é aquela que agrega a maior felicidade entre os membros, o que leva à regra da maioria; ii) o teorema de Condorcet afirma que a probabilidade de uma resposta correta é maior quando a questão é
} 
possibilitam o agir coletivo, excluindo as razões pessoais dos agentes na formação de suas vontades em se tratando de condutas relacionadas a temas em que se mostra necessária a cooperação entre os indivíduos. Jeremy Waldron resume esse ponto da seguinte maneira:

Compreendido dessa maneira, o estado de direito não é simplesmente o princípio de que os funcionários e os cidadãos devem aplicar e obedecer a lei mesmo quando ela vai contra os seus interesses. É o princípio de que um funcionário ou um cidadão deve fazer isso mesmo quando a lei - na sua opinião confiante - for injusta, moralmente incorreta, ou mal orientada como questão de política. Pois a decretação da medida em questão é indício da existência de uma opinião quanto à sua justiça, sua moralidade ou sua conveniência, que é diferente da deles; alguém deve ter sido a favor da lei ou achado que era uma boa ideia. Em outras palavras, a existência da lei, juntamente com a opinião do indivíduo, é indício de discordância moral na comunidade quanto à questão subjacente. $\mathrm{O}$ funcionário deixar de implementar a lei porque ela é injusta ou o cidadão fazer outra coisa que não aquilo que a lei exige porque isso seria mais justo equivale a abandonar a própria ideia de lei - a própria ideia de comunidade que toma posição em uma questão da qual os seus membros discordam. É um retorno à situação em que cada pessoa simplesmente age com base no próprio julgamento e faz o que lhe parece correto ${ }^{14}$.

A compreensão das normas jurídicas como razões de segunda ordem possibilita entender com maior facilidade outros aspectos relacionados à ideia de Estado de Direito. As normas, ao excluírem as razões pessoais sobre determinado assunto, diminuem o grau de discricionariedade dos intérpretes, tanto dos governantes como dos governados, trazendo previsibilidade e igualdade de tratamento. Tem-se, então, que Estado de Direito é aquele que se utiliza de normas jurídicas como pautas de conduta, cuja função é excluir as razões pessoais dos agentes na formação do juízo, diminuindo sua discricionariedade, seja limitando a atuação estatal ou demarcando a esfera de autonomia individual, com o objetivo de promover a coordenação das condutas e a eficiência no trato intersubjetivo em uma sociedade plural. Para uma melhor compreensão inicial do tema, dois aspectos merecem ser esclarecidos.

Em primeiro lugar, o ideal do Estado de Direito só se mostra plausível se as pessoas realmente conseguirem utilizar as normas como guias de conduta. Em uma sociedade que trata seus membros como sujeitos autônomos e capazes, as normas devem ser acessíveis para que eles possam organizar suas vidas da forma como melhor entenderem. Nesse contexto, a

decidida por muitos do que quando se dá individualmente; e iii) Aristóteles comprovou que uma multidão de pessoas, por meio de uma síntese deliberativa, chegará a uma resposta melhor do que o mais inteligente dos homens.

${ }^{14}$ WALDRON, 2003, p. 44-45. 
capacidade de compreender e autoaplicar os comandos normativos revela-se essencial para que se caracterize um ordenamento como justo ${ }^{15}$. Normas incompreensíveis ou misteriosas produzem vários efeitos deletérios para o Estado de Direito. Por um lado, se as pessoas não conhecerem o conteúdo das normas, elas continuarão a se valer das próprias razões, o que minaria o agir coletivo. Por outro, caso as normas sejam vagas e obscuras, aumenta-se consideravelmente a discricionariedade dos agentes públicos encarregados de aplicá-las, que, em última análise, poderão manipular as condutas dos membros da comunidade ${ }^{16}$.

Em segundo lugar, conforme Manoel Gonçalves Ferreira Filho (2009, p. 175-212) deixa claro ao identificar a justicialidade como subprincípio do Estado de Direito, a mera existência de normas jurídicas não é garantia de sua observância. Isso porque, da mesma forma como o pluralismo razoável faz com que as pessoas discordem quanto às razões que devem ser positivadas como normas, as diferentes perspectivas e experiências individuais conduzem a um desacordo com relação à interpretação dos textos legais. Reduzir o Estado de Direito a um conjunto de normas seria o mesmo que ignorar uma das facetas essenciais do fenômeno jurídico. Sabe-se que divergências quanto à interpretação de dispositivos legais podem gerar disputas tão ou mais acirradas do que questões morais e políticas ${ }^{17}$. No contexto, a forma como as instituições públicas resolvem os conflitos jurídicos também se reveste de importância para um Estado que tenha como meta tratar seus cidadãos com dignidade e respeito. Trata-se daquilo que Jeremy Waldron (2010a, p. 10-25) denominou de aspecto procedimental do Estado de Direito, relacionado ao modo pelo qual um processo judicial é instaurado, desenvolvido e decidido.

Assim, não só a possibilidade de os cidadãos se guiarem de maneira segura por meio de normas jurídicas possui uma dimensão moral para o Estado de Direito. A prerrogativa de expor sua compreensão sobre o significado da norma perante um juízo imparcial que analisará com seriedade seus argumentos também possui um valor intrínseco. Com efeito, há um

\footnotetext{
${ }^{15}$ Lon Fuller (1969), em obra seminal, enumerou oito princípios formais relacionados à autoaplicação das normas por parte dos cidadãos, que correspondem à "moralidade interna" no Direito. Eis os princípios: i) generalidade; ii) publicidade; iii) prospectividade; iv) inteligibilidade; v) consistência (ausência de graves contradições); vi) estabilidade; vii) possibilidade de cumprimento; e viii) administração da Justiça de forma congruente com o que estatui as normas.

${ }^{16}$ Esse alerta foi feito por Herbert L. A. Hart, para quem a alienação dos cidadãos frente ao ordenamento jurídico eventualmente geraria uma situação em que eles poderiam ser manipulados pelos detentores do poder, assim como as ovelhas em relação ao seu pastor, o que, obviamente, geraria o risco de serem levados ao abatedouro. Segundo o autor, o que caracterizaria esse descolamento entre o Direito e a sociedade seria a falta da percepção daquilo que ele denominou como aspecto interno do fenômeno jurídico, o que ocorreria exatamente quando as pessoas deixassem de compreender o significado das normas e o modo pelo qual elas são criadas. Cf. HART, 1997, p. 100-117.

${ }^{17}$ Cf. o artigo de Robert Post e Reva Siegel (2007) sobre o papel do chamado "backlash" em resposta a decisões judiciais nos EUA que acabam por gerar mudança na compreensão da própria Constituição.
} 
sentimento geral de que o Estado de Direito está sendo violado quando se tem notícia de que os prisioneiros da chamada guerra contra o terror, custodiados em Guantánamo, serão julgados sem assistência de advogados, com base em testemunhos obtidos mediante tortura e tendo como árbitros militares americanos ${ }^{18}$. Em sentido semelhante, a doutrina continua reticente quanto aos julgamentos realizados no âmbito administrativo, sob o fundamento de que a imparcialidade desses procedimentos está muito aquém dos patamares exigidos em um Estado de Direito ${ }^{19}$. Enfim, qualquer forma que diminua a capacidade dos cidadãos de argumentar ou de ver seus argumentos apreciados com neutralidade abala a credibilidade de um regime que se diz legítimo.

Há, pois, a necessidade da observância de alguns requisitos no que tange à faceta procedimental do Estado de Direito. A possibilidade de se ingressar em juízo caso haja dúvidas quanto à aplicação do Direito é um deles. No Brasil, a chamada doutrina do acesso à justiça, seguindo as lições de Mauro Capelletti (1988), vem se dedicando profundamente ao tema, diagnosticando os gargalos do sistema e apontando soluções para facilitar o acesso ${ }^{20}$. A instauração de procedimentos imparciais que possibilitem aos cidadãos comprovar as suas versões dos fatos é outra característica essencial. Isso envolve determinadas medidas, como: ser ouvido por um juiz imparcial, devidamente qualificado para sua função, que decida com base em provas produzidas no bojo do processo; ser representado e aconselhado por advogado em todas as fases; ter acesso às instâncias superiores; poder contestar as provas produzidas pela outra parte etc. Trata-se do que se convencionou chamar de princípio do devido processo legal processual ${ }^{21}$.

Instaurada a relação processual contraditória, as partes devem ter a chance de argumentar ante o juiz as razões pelas quais entendem ser aplicável, ou não, determinado dispositivo legal ao caso. Não obstante as inúmeras regras e princípios existentes em um ordenamento jurídico, espera-se que as partes consigam formular um argumento de maneira coerente, apresentando uma concepção de Direito que seja compatível com o material legal

\footnotetext{
${ }^{18}$ Johan Steyn (2003), ex-membro da Casa dos Lordes inglesa (antiga Suprema Corte britânica), definiu a situação de Guantánamo como um "buraco-negro" jurídico.

${ }^{19}$ Justen Filho (2002, p. 548) ressalta que "o traço distintivo fundamental entre função administrativa e função jurisdicional consiste na neutralidade do órgão julgador", concluindo que "por maior que possa configurar a 'isenção' da autoridade administrativa, nunca existirá uma imparcialidade na acepção que se configura no âmbito jurisdicional".

${ }^{20}$ Cf. CINTRA; GRINOVER; DINAMARCO, 2012, Cap. 3.

${ }^{21}$ De acordo com Chemerinsky (2006, p. 545-546), o que diferencia o princípio do devido processo legal processual do substantivo é que, no primeiro caso, estabelecem-se os ritos a que o governo deve obedecer para atingir o patrimônio, a liberdade ou a vida de qualquer pessoa. Já no segundo caso, ao se invocar a cláusula do devido processo legal, está-se questionando se o governo possui alguma razão legítima para atingir o patrimônio, a liberdade ou a vida do cidadão, ainda que observados os procedimentos legais.
} 
preexistente. Ou seja, oportuniza-se aos cidadãos, por meio do procedimento judicial, a possibilidade de expor sua visão de mundo sobre os pré-compromissos políticos firmados pela sociedade, explicando o motivo pelos quais entendem que as atitudes por eles tomadas estão de acordo com o que o ordenamento jurídico de fato preceitua. As partes adversas irão apresentar uma porção de argumentos concorrentes, alegando, por exemplo, que o resultado pretendido por uma das partes não pode ser inferido das normas ou dos precedentes, enquanto a outra, em contrapartida, alegará que uma interpretação sistemática conduz inexoravelmente ao que a parte ex adversa nega, e assim por diante.

O que se espera, em um Estado de Direito, é que o magistrado que for decidir este caso acate os argumentos daquele que, em face das normas existentes, apresente o melhor argumento. Espera-se que o juiz, ao elaborar sua própria interpretação dos fatos e do Direito, adote a concepção mais persuasiva daquilo que foi construído pela sociedade por meio de suas instituições até aquele momento, exigindo do intérprete o que Ronald Dworkin denominou o dever de integridade $e^{22}$ para com o ordenamento jurídico. Não por outro motivo considera-se equivocado que o julgador decida o caso com base, exclusivamente, em suas razões pessoais, devendo a solução encontrada guardar congruência com o material jurídico anteriormente produzido. De outro modo, caso se considerasse aceitável julgar um caso divorciado das razões legais, estaria sendo negado o caráter de razão excludente ou de razão de segunda ordem das normas jurídicas, jogando por terra toda a lógica inerente ao discurso do Estado de Direito. Assim, a aderência ou fidelidade ao texto legal é condição essencial para que se considere uma atuação estatal legítima.

No âmbito do controle de constitucionalidade, o exercício jurisdicional pode por vezes apresentar-se problemático. Isso porque as Constituições normalmente contêm uma série de normas que expressam visões de mundo contraditórias, como é o caso do direito à propriedade em contraposição ao princípio da função social da propriedade na Constituição

\footnotetext{
${ }^{22}$ Cláudio de Oliveira (2009, p. 5466) resume o modelo de integridade de Dworkin da seguinte forma: "no modelo da integridade 'inclusiva', defendido por Dworkin, os controversos princípios de moralidade que os juízes devem usar para justificar suas decisões nos casos difíceis, possuem uma dupla limitação. Em primeiro lugar, eles não podem ser uma mera expressão do desejo contingente de justiça de alguns magistrados. Na atividade de construção destes princípios o passo inicial é dado pelos demais membros da comunidade: os juízes devem apresentar princípios de justiça capazes de apresentar de um modo coerente as decisões políticas adotadas pela comunidade, articulando de modo coerente as convicções de 'justiça' fixadas, de tempos em tempos, por exemplo, por representantes eleitos. Em segundo lugar, a coerência pretendida pela integridade não se resume a oferecer a melhor concepção (a mais coerente) do conjunto de decisões sobre 'justiça' adotadas pela comunidade. Faz parte da atividade do juiz respeitar também os princípios de 'equidade' e 'devido processo'. Especialmente no caso da 'equidade', que define os procedimentos democráticos de legislação, respeitar tais princípios pode fazer com que juízes se deparem com princípios de 'justiça' que, não obstante não seja perfeitamente coerente em relação às demais decisões sobre 'justiça', ainda assim deva prevalecer em virtude dos princípios de 'equidade' que também prevalecem”.
} 
Brasileira de 1988. As possibilidades interpretativas que surgem na articulação das diversas cláusulas constitucionais podem levar o intérprete a acreditar de maneira equivocada que as suas razões devem ser as únicas ou as mais importantes na formação do juízo.

A ânsia de modificar a realidade social por meio da hermenêutica jurídica inerente ao discurso de várias doutrinas contemporâneas pode trazer sérios riscos ao Estado de Direito, transformando o argumento jurídico em um discurso empobrecido sobre a visão ideal de mundo para o intérprete. Em outras palavras, a baixa densidade normativa das cláusulas constitucionais pode ser interpretada erroneamente como um convite para fazer valer as considerações políticas e morais do hermeneuta em detrimento do que foi estabelecido no processo político majoritário. Como consequência dessa atitude, a prática jurídica, ao invés de afunilar o espectro de considerações do intérprete, serve como camuflagem para uma atuação eminentemente política. Alguns exemplos facilitarão a compreensão dessa angústia.

\section{O Neoconstitucionalismo e o "fim" do Estado de Direito}

Em 22 de setembro de 2010, o Supremo Tribunal Federal iniciou o julgamento quanto à aplicabilidade da lei complementar $\mathrm{n}^{\circ}$. 135/10, de 4 de junho de 2010 - chamada lei da ficha limpa, que criou uma série de novas condições de elegibilidade para candidatos a cargos eletivos - às eleições gerais de $2010^{23}$. Apesar de haver uma regra expressa no art. 16 da Constituição Federal com sentido claro de que "a lei que alterar o processo eleitoral entrará em vigor na data de sua publicação, não se aplicando à eleição que ocorra até um ano da data de sua vigência", a menos de um mês do pleito - que ocorreria no dia 3 de outubro - a Corte discutiu por quase 11 horas sobre a incidência (ou não) do dispositivo constitucional ao caso.

O cerne da questão jurídica foi decidir se a expressão "processo eleitoral" englobaria todas as etapas desde o fim do período de filiação partidária, que ocorre um ano antes das eleições, ou se se limitaria ao período após as convenções partidárias, ocorridas em junho de 2010. Os ministros favoráveis à aplicação imediata argumentavam que a lei que estabeleceu novas hipóteses de inelegibilidade deveria ser observada, pois regularia período anterior ao processo eleitoral, de maneira que os chamados fichas sujas não poderiam ser escolhidos como candidatos pelos partidos nas convenções, afastando-se, assim, o óbice constitucional.

\footnotetext{
${ }^{23}$ Supremo Tribunal Federal, Recurso Extraordinário no. 630.147, Min. Rel. Ayres Britto, julgado em 29/09/10, acórdão publicado no DJ-e de 05/12/11.
} 
O que chamou a atenção no debate foi o fato de que alguns ministros favoráveis à aplicação da lei fizeram um exercício de ponderação, afastando a aplicação da regra constitucional em face ao princípio da moralidade ${ }^{24}$. Ressalte-se, novamente, que a questão posta nos autos se restringia à aplicabilidade da lei ao pleito de 2010 , não se referindo à constitucionalidade material das hipóteses de inelegibilidade. Isto significa que o ingresso em uma argumentação acerca do princípio da moralidade era absolutamente desnecessário, pois, em regra, a data da entrada em vigência de determinada lei independe do conteúdo da norma. Ao que parece, para os magistrados que invocaram princípios constitucionais para justificar a aplicabilidade da novel legislação às eleições de 2010, o significado da expressão processo eleitoral seria variável a depender do resultado da interpretação, se em conformidade (ou não) com suas convicções morais. Dito de outra forma, a norma constitucional não teve o condão de excluir as razões pessoais do intérprete em seu raciocínio prático.

Se é certo que a Constituição possui várias cláusulas vagas cuja aplicação por vezes se mostra problemática, não se pode olvidar que grande parte das normas constitucionais possui alto grau de determinação que não demanda maiores reflexões interpretativas ${ }^{25}$. Em situações tais, em uma sociedade que cultua os valores inerentes ao Estado de Direito, a atitude de decidir pela não aplicação de uma regra tendo por fundamento princípios revela-se, no mínimo, questionável. No caso do art. 16 da Carta Magna, o motivo que ensejou a edição da norma constitucional foi o de proibir que, às vésperas do pleito eleitoral, se modifiquem as regras do jogo, independentemente de seu conteúdo ${ }^{26}$. Afastar a incidência da referida cláusula constitucional significa, aparentemente, substituir as razões da norma pelas do intérprete.

\footnotetext{
${ }^{24}$ Nesse sentido, confira o seguinte trecho do voto da Ministra Carmen Lúcia, para quem "as finalidades éticas do art. 16 deverão ainda ser sopesadas com o sentido teleológico concretizado pelo legislador complementar ao editar a lei de inelegibilidades (proteção da probidade administrativa, da moralidade para o exercício de mandatos, considerada a vida pregressa dos candidatos, normalidade e legitimidade das eleições contra abuso do poder político e econômico)". (RE n 630.147, p. 97).

${ }^{25}$ Humberto Ávila $(2009$, p. 189) adverte que "a opção constitucional foi, primordialmente, pela instituição de regras e, não, de princípios. Tanto que a Constituição Federal de 1988 é qualificada de 'analítica', justamente por ser detalhista e pormenorizada, característica estruturalmente vinculada à existência de regras, em vez de princípios".

${ }^{26}$ De acordo com Celso Bastos e Ives Gandra (1989, $2^{\circ}$ vol., p. 597), ao comentar o referido dispositivo: "A preocupação fundamental consiste em que a lei eleitoral deve respeitar o mais possível a igualdade entre os diversos partidos, estabelecendo regras equânimes, que não tenham por objetivo favorecer nem prejudicar qualquer candidato ou partido. Se a lei for aprovada já dentro do contexto de um pleito, com uma configuração mais ou menos delineada, é quase inevitável que ela será atraída no sentido dos diversos interesses em jogo, nessa altura já articulados em candidaturas e coligações. A lei eleitoral deixa de ser aquele conjunto de regras isentas, a partir das quais os diversos candidatos articularão as suas campanhas, mas passa ela mesma a se transformar em elemento da batalha eleitoral. É, portanto, a vacatio legis contida nesse art. 16 medida saneadora e aperfeiçoadora do nosso processo eleitoral".
} 
Há outros casos problemáticos, como os em que o Supremo Tribunal Federal declarou a inconstitucionalidade de leis utilizando unicamente como parâmetro de controle o princípio da proporcionalidade ou razoabilidade ${ }^{27}$, o que significa dizer que os juízes, diante de uma norma infralegal, consideraram que as razões jurídicas legitimamente positivadas não seriam apropriadas sob a perspectiva do intérprete. Conquanto a Constituição Federal de 1988 tenha conferido ao Poder Judiciário a prerrogativa de aferir a constitucionalidade de leis, isso não parece significar que ela tenha outorgado aos juízes o poder de julgar o legislador. Inexistindo cláusula constitucional claramente violada, não há que se falar em controle das opções legislativas.

No campo doutrinário, o que tem aparentemente justificado essas intervenções questionáveis do Supremo Tribunal Federal na esfera de conformação legislativa é o que se convencionou chamar de teoria do Neoconstitucionalismo. De fato, tanto a aplicação direta e a efetividade de princípios constitucionais como a prática da ponderação de valores são ferramentas interpretativas usualmente associadas a essa corrente de pensamento cujas principais teses foram resumidas por Luís Prieto Sanchís:

[M]ás principios que reglas; más ponderación que subsunción; omnipotencia de la Constitución em todas las áreas jurídicas y em todos conflictos minimamente relevantes, em lugar de espacios exentos em favor de la opción legislativa o regulamentaria; omnipotencial judicial em lugar de autonomia del legislador ordinário; y, por ultimo, coexistência de uma constelación plural de valores, a veces tendencialmente contradictórios, em lugar de homogeneidad ideológica ${ }^{28}$

Ocorre que, levadas ao extremo, essas teses aniquilam a ideia de Estado de Direito. Se a constitucionalidade das normas for constantemente questionada pelos intérpretes utilizando-se princípios como parâmetro e ponderação como técnica - elas perderão sua capacidade de guiar as condutas dos indivíduos, além de dar ensejo a uma atuação mais subjetiva por parte dos agentes públicos. Explica-se: ao se constatar que os princípios constitucionais irradiam por todo o ordenamento jurídico, torna-se possível argumentar, em qualquer caso, por mais ordinário que seja, a favor do resultado que se considera o mais correto, uma vez que o texto fundamental alberga uma infinidade de valores contraditórios em sua essência.

\footnotetext{
${ }^{27}$ Cf. Supremo Tribunal Federal, Ação Direta de Inconstitucionalidade no. 855, Min. Rel. Octavio Gallotti, julgada em 06/03/08, acórdão publicado no DJ-e de 27/03/09; e Supremo Tribunal Federal, Medida Cautelar em Ação Direta de Inconstitucionalidade nº 4.467, Min. Rel. Ellen Gracie. Brasília, acórdão publicado no DJe de 01/06/12.

${ }^{28}$ SANCHÍS, 2003, p. 117.
} 
Disseminadas as teses do Neoconstitucionalismo e tornada endêmica a prática de contestação das normas, os indivíduos acabarão por ter que reconstruir em todos os casos as razões que entendem ser relevantes para a solução de seus problemas, perdendo-se, assim, em eficiência e em coordenação, valores inerentes ao Estado de Direito. Nesse sentido, a utilização do ambíguo vocábulo fim no título da presente Tese foi proposital. Pretende-se abordar o fim - no sentido de finalidade - do Estado de Direito para se questionar se as teses defendidas pela doutrina do Neoconstitucionalismo estariam dando fim aniquilando/exterminando - (a) esse ideal político.

Em essência, a discussão gira em torno do modo como a Constituição deve ser interpretada. Enquanto o ideal do Estado de Direito sugere que o papel dos tribunais é o de manter os compromissos políticos assumidos pela sociedade - inclusive os constitucionais - o Neoconstitucionalismo incita o intérprete a "explorar os potenciais emancipatórios presentes no texto constitucional" 29 , vislumbrando na interpretação judicial um dos mais, senão o mais, importante mecanismo de transformação social, o que leva a uma constante revisão da compreensão do texto fundamental ${ }^{30}$.

A situação torna-se mais preocupante quando se percebe que nossa Constituição dá margem a interpretações de toda ordem. Há princípios sociais e liberais. Requer-se a elaboração de políticas para reduzir as desigualdades sociais e regionais ao mesmo tempo em que se impõe eficiência econômica no trato da coisa pública. $\mathrm{O}$ direito à propriedade é garantido desde que se respeite a sua função social. Ante tal cenário, uma interpretação constitucional progressista, dissociada do contexto político, deságua em pragmatismo jurídico $^{31}$, em que as normas jurídicas mencionadas na fundamentação da decisão, ao invés de restringir o seu juízo cognitivo, servem apenas de argumento retórico para legitimar a escolha que o intérprete entende produzir as melhores consequências.

A presente Tese pretende explorar essa tensão entre o Estado de Direito e as teses defendidas pelo Neoconstitucionalismo, apontando em que medida as práticas relacionadas a essa teoria enfraquecem e/ou debilitam a ideia de organização da vida social por meio de normas jurídicas.

\footnotetext{
${ }^{29}$ MAIA, 2009, p. 118.

${ }^{30}$ De acordo com Luís Roberto Barroso (2009a, p. 210), a mutação constitucional é a alteração informal da Constituição, que modifica o seu sentido e alcance, sem que se opere, no entanto, qualquer modificação em seu texto.

${ }^{31}$ Diego Arguelhes e Fernando Leal (2010, p. 173) definem pragmatismo jurídico "como uma concepção que atribui às consequências práticas das decisões judiciais um peso decisivo na atuação dos juízes”.
} 


\section{Objetivos e plano de trabalho}

O escopo da pesquisa é analisar criticamente as teses defendidas pelo Neoconstitucionalismo a partir da reconstrução interpretativa do ideal político Estado de Direito. Atualmente, fala-se muito em princípios, ponderação e direitos fundamentais, relegando-se a legalidade a segundo plano. O que motivou esta Tese foi elucidar conceitualmente um sentimento de perda de dignidade gerado quando juízes decidem diretamente com base em valores constitucionais em detrimento do texto legal. A possibilidade de emancipação social por meio do Direito, inerente ao discurso neoconstitucional, tem sido festejada pela doutrina e endossada por membros da magistratura, calando as vozes dos que acreditam que decisões marcadas pela flexibilização das normas e das obrigações jurídicas sejam injustas.

A linguagem utilizada pelo Neoconstitucionalismo de reabilitação da moral no discurso jurídico também tem sido uma barreira para aqueles que não concordam com as teses dessa corrente doutrinária, pois sugere que seus críticos seriam necessariamente contrários à moralização das relações intersubjetivas, sendo logo taxados pejorativamente como positivistas ultrapassados. Mas a partir de uma investigação analítica sólida, pautada por autores frequentemente reivindicados pelos próprios neoconstitucionalistas em defesa de suas teses, será possível elaborar uma crítica consistente e não-positivista, demonstrando que o respeito à legalidade também possui uma dimensão moral na medida em que vincula os conceitos de dignidade humana e Estado de Direito. Em outras palavras, a flexibilização das normas e obrigações jurídicas com fundamento no resguardo de uma moralidade difusa e casuística resvala, na verdade, em uma violação crônica do conteúdo moral que sempre está presente no conceito de legalidade no Estado de Direito.

Há, portanto, duas tarefas a serem desempenhadas na presente Tese. Uma é a reconstrução interpretativa do Estado de Direito, explicitando conceitualmente a razão pela qual esse ideal político tornou-se amplamente difundido e algo moralmente desejado nas democracias contemporâneas. A outra é diagnosticar os riscos inerentes à aceitação e à disseminação das teses do chamado Neoconstitucionalismo para o Estado de Direito. Não obstante haver inúmeros estudos sobre a possível tensão entre o controle de constitucionalidade e a democracia ${ }^{32}$, não há ainda na literatura pátria um trabalho que trate de

\footnotetext{
${ }^{32} \mathrm{Na}$ doutrina pátria, vale mencionar o excelente trabalho de Conrado Hubner Mendes (2008) que, a partir do mesmo marco teórico utilizado nessa Tese (Waldron), analisou a conveniência do aparelhamento de um sistema de controle de constitucionalidade pelo prisma da legitimidade democrática.
} 
maneira sistemática o tema aqui abordado, o que justifica o empreendimento a ser desenvolvido.

A tarefa será dividida em sete etapas. No primeiro capítulo, buscar-se-á definir Neoconstitucionalismo e enquadrá-lo no debate constitucional contemporâneo. A origem do termo, o contexto de sua formulação e o modo como foi importado para o debate acadêmico nacional serão as primeiras preocupações. Após identificar a inspiração e a essência desse movimento doutrinário, a questão da legitimidade da jurisdição constitucional será abordada com a finalidade de localizar o argumento neoconstitucional nesse debate. Já no segundo capítulo serão analisados os textos de Eduardo Ribeiro Moreira, Luís Roberto Barroso, Antônio Cavalcanti Maia e Daniel Sarmento, quatro dos principais autores neoconstitucionalistas, com o intuito de identificar as principais teses por eles compartilhadas.

No terceiro capítulo será tratada a questão do papel normativo das teorias neoconstitucionais. Será defendido, com base em Dworkin, que toda abordagem jurídica reflete uma concepção específica que, apoiada em valores, vislumbra na prática jurídica um propósito a ser promovido. No caso do Neoconstitucionalismo, o principal valor cultuado é o da transformação social, o que implica uma série de consequências que serão abordadas no capítulo quarto. A ênfase no Poder Judiciário, a preferência por princípios, a utilização de argumentos de política e a ponderação de valores - as principais teses da concepção jurídica neoconstitucional - serão criticamente apreciadas, demonstrando-se como essas ideias são articuladas por esses autores de maneira a desencadear uma perigosa fluidez interpretativa. Argumentar-se-á que, em virtude de seu esforço teórico de se livrar das amarras legais e de seu foco nos resultados interpretativos, o Neoconstitucionalismo se transforma em uma espécie de pragmatismo jurídico, gerando uma série de consequências negativas para a ideia de Estado de Direito.

Os capítulos quinto e sexto serão destinados à definição dos elementos que compõem o Estado de Direito, iniciando-se a análise a partir de uma reconstrução histórica da expressão Estado Democrático de Direito, que acabou por ser positivada em nossa Constituição. Será demonstrado que, em virtude da incorporação desastrada dessa expressão, aliada com o desprestígio das normas jurídicas em razão do longo período de ditadura militar e das teses neutras defendidas pelo positivismo jurídico, desvirtuou-se, no Brasil, o debate sobre o que seja Estado de Direito, levando a um esvaziamento de significado desse ideal político.

A partir da concepção waldroniana, tentar-se-á resgatar a essência do termo, demonstrando que o que torna o Estado de Direito um ideal político atrativo é o modo digno pelo qual os cidadãos são tratados em uma sociedade regida por normas jurídicas 
legitimamente positivadas. Com o aporte das teorias de Jeremy Waldron, Joseph Raz e Ronald Dworkin, será formulado o modelo focal de administração da vida coletiva por meio do Direito para, ao final, apontar, no sétimo capítulo, em que medida as teses neoconstitucionais representam um perigo para o Estado de Direito. 


\section{Capítulo 1 - A alma do Neoconstitucionalismo: inspiração e enquadramento no debate constitucional contemporâneo}

\section{1 - Considerações iniciais: conceito e essência}

Nos últimos anos, desde a publicação, em 2003, da coletânea de artigos organizada pelo jurista mexicano Miguel Carbonell sobre o Neoconstitucionalismo ${ }^{1}$, o tema tem sido alvo de intenso debate na academia brasileira. Não obstante inúmeros autores, como Robert Alexy e Ronald Dworkin ${ }^{2}$, já houvessem desenvolvido na década de 80 teorias constitucionais complexas, consistentes e aptas a traduzir o papel dos juízes constitucionais nas democracias contemporâneas, a mudança de postura do Supremo Tribunal Federal - que, desde o começo do século XXI, tem assumido cada vez mais o protagonismo na esfera política brasileira ${ }^{3}$ associada à criação de um rótulo de fácil memorização que expressa postura favorável a uma maior intervenção judicial ${ }^{4}$ têm atraído cada vez mais adeptos ao Neoconstitucionalismo.

A elaboração de um novo direito constitucional ${ }^{5}$, na linguagem de Luís Roberto Barroso, ou de uma nova cultura jurídica ${ }^{6}$, nos dizeres do autor espanhol Luis Prieto Sanchís, que explique, justifique e fomente a imiscuição por parte dos tribunais em questões antes adstritas à seara política, como aborto ou pesquisas com células-tronco, tem servido de mote

${ }^{1}$ CARBONELL, 2003. Mais recentemente, o mesmo autor organizou duas novas coletâneas de artigos também dedicadas ao Neoconstitucionalismo. Cf. CARBONELL, 2007; CARBONELL, JARAMILLO, 2010.

2 Trata-se das obras Teoria dos Direitos Fundamentais (2008) e Law's Empire (1986), respectivamente, ambas originariamente publicadas no ano de 1986.

${ }^{3}$ Carlos de Azevedo Campos (2011, p. 547) afirma que o Supremo Tribunal Federal vive uma nova fase de ativismo judicial e judicialização da política em que há a superação de jurisprudências autorrestritivas adotadas a partir da jurisprudência do Ministro Moreira Alves - e a aceitação de uma série de propostas ativistas - identificadas com o Ministro Gilmar Mendes. A consolidação desse novo momento teria ocorrido “com as nomeações de novos ministros feitas pelo presidente Lula entre 2003 e 2006, e com a própria aposentadoria do Ministro Moreira Alves". Independentemente da identificação das teses defendidas por determinados magistrados específicos, o que importa, para os fins da presente Tese, é a percepção de que houve uma mudança de postura por parte da Suprema Corte a partir da década passada.

4 André Ramos Tavares chega a conclusão semelhante ao afirmar que: "Sob o rótulo de 'Neoconstitucionalismo' se têm agrupado correntes e teorias ('pluralidade de pensamentos') que conclamam o Judiciário a atuar como protagonista da idéia de Estado Constitucional Social de Direito”. (texto de apresentação de MOREIRA, 2008, p. 11)

${ }^{5}$ Segundo Luís Roberto Barroso (2008, p. 47), “o novo direito constitucional brasileiro, cujo desenvolvimento coincide com o processo de redemocratização e reconstitucionalização do país, foi fruto de duas mudanças de paradigma: a) a busca da efetividade das normas constitucionais, fundada na premissa da força normativa da Constituição; b) o desenvolvimento de uma dogmática da interpretação constitucional, baseada em novos métodos hermenêuticos e na sistematização de princípios especificos de interpretação constitucional".

${ }^{6}$ SANCHÍS, 2003, p. 101. 
para a proliferação de trabalhos nacionais sobre o tema ${ }^{7}$. Até mesmo alguns Ministros do Supremo Tribunal Federal têm mencionado o termo para designar uma nova quadra do direito constitucional no Brasil. O Ministro Luiz Fux, em obra recentemente publicada, confessou-se, em certa medida, adepto dessa corrente doutrinária. Ao relatar sua experiência em seu primeiro ano na Corte Suprema, o magistrado, juiz de carreira que galgou posições de destaque em todas as instâncias, afirmou:

O Supremo Tribunal Federal impôs-me inaugurar uma nova forma de pensar o direito, porquanto a Carta Constitucional, mercê de abarcar regras, contém inúmeros princípios, exigindo, na mais das vezes, a denominada técnica de ponderação de valores, notadamente nas causas em que a ausência de regras explícitas alarga o campo interpretativo e criativo da funcão judicial.

Esse é um fenômeno mais recente, coincidente, temporalmente com o surgimento de um Neoconstitucionalismo cuja denominação também não é unívoca ${ }^{8}$.

Em sentido semelhante, o Ministro Celso de Mello, decano da Corte Constitucional, em julgamento sobre o reconhecimento da união homoafetiva como entidade familiar, referiuse ao Neoconstitucionalismo como o marco teórico apto a legitimar a interpretação judicial construtiva, baseada em princípios que, no seu sentir, têm desencadeado a proeminência cada vez maior do Poder Judiciário na vida política do país. Eis o trecho de seu voto que faz menção expressa ao Neoconstitucionalismo:

A forca normativa de que se acham impregnados os princípios constitucionais $\underline{\text { e }}$ a intervenção decisiva representada pelo fortalecimento da jurisdição constitucional exprimem aspectos $\underline{\text { de }} \underline{\text { alto }} \underline{\text { relevo }} \underline{\text { que delineiam }}$ alguns dos elementos que compõem o marco doutrinário que confere suporte teórico ao Neoconstitucionalismo, em ordem a permitir, numa perspectiva de implementação concretizadora, a plena realização, em sua dimensão global, do próprio texto normativo da Constituição?

\footnotetext{
${ }^{7}$ No Brasil, Regina Quaresmo, Maria Lúcia de Paula Oliveira e Farlei Martins de Oliveira (2009) também coordenaram uma coletânea de 41 (quarenta e um) artigos sobre o tema. Além disso, há pelo menos oito livros que utilizam o termo "Neoconstitucionalismo" em seu título. (Cf. CADERMATORI; DUARTE, 2010; CAMBI, 2010; DIMOULIS; DUARTE, 2008; DUARTE; POZZOLO, 2006; MATIAS, 2009; MOLLER, 2011; MOREIRA, 2008; SANTOS, 2011). Inúmeros artigos já foram publicados em outros veículos de divulgação, sendo difícil encontrar um periódico que não tenha um artigo sobre o assunto, destacando-se, pela sua popularidade: BARROSO, 2007; SARMENTO, 2010.

${ }^{8}$ FUX, 2012, p. 34, grifo nosso.

${ }^{9}$ Supremo Tribunal Federal. Ag. Reg. no Recurso Extraordinário no. 477.544/MG, Rel. Min. Celso de Mello, Segunda Turma, julgado em 16/08/2011, publicado no DJ-e de 26/08/2011, p. 307, grifos do autor.
} 
Essas menções explícitas ao Neoconstitucionalismo por parte de integrantes da Suprema Corte podem ser consideradas uma consequência da ampla divulgação e da adesão desse movimento acadêmico no Brasil. De fato, juristas de destaque como Luís Roberto Barroso (2007), Ingo Wolfgang Sarlet (2009), Antônio Cavalcanti Maia (2009), Daniel Sarmento (2009), Diogo de Figueiredo Moreira Neto (2009) e Lênio Luiz Streck (2009) aderiram explicitamente a essa corrente, o que tem contribuído para a difusão do tema.

\subsection{1 - A difícil tarefa de definir Neoconstitucionalismo}

Apesar da ampla aceitação do Neoconstitucionalismo no Brasil, não há uma concepção ${ }^{10}$ unívoca dessa doutrina. As diferentes correntes filosóficas daqueles que se intitulam como tal fazem com que se mostre infrutífera qualquer tentativa de se agrupar em uma definição todas as teses defendidas por essa corrente doutrinária. Não há dúvidas de que as lições de Ingo Wolfgang Sarlet, por exemplo, em vários pontos se distanciam das de Lênio Luiz Streck. Enquanto o primeiro acredita na utilização de técnicas de interpretação constitucional, o segundo se mostra contrário ao emprego de qualquer método de hermenêutica jurídica ${ }^{11}$. Da mesma forma, enquanto Antônio Cavalcanti Maia se diz adepto do procedimentalismo de Jürgen Habermas ${ }^{12}$, Luís Roberto Barroso adota um posicionamento de cunho nitidamente substantivo, bastante influenciado pelo modelo de ponderação construído por Robert Alexy ${ }^{13}$.

Há quem afirme de maneira peremptória que o Neoconstitucionalismo se apresenta como "um novo paradigma tanto na teoria quanto na prática dos tribunais", que outros defendem que "o que a doutrina tem designado de Neoconstitucionalismo, em princípio, não substancia, organicamente, em nova teoria constitucional" ${ }^{\prime 15}$. Obviamente, essa

\footnotetext{
${ }^{10}$ Segundo Ronald Dworkin (1986, p. 70-72), o que diferencia conceito de concepção é o nível de abstração interpretativa. Enquanto o conceito encontra-se em um elevado nível de abstração, permitindo que a ideia geral do objeto seja compartilhada pelos interlocutores, cada concepção busca apresentar o conceito em seu melhor ângulo, explicitando os valores substantivos que animam a versão do intérprete. As diferenças interpretativas das diversas visões do objeto consubstanciam-se em concepções alternativas do mesmo conceito. Nesse ponto, é possível dizer que, não obstante muitos autores se identificarem como neoconstitucionalistas, há, na verdade, várias concepções neoconstitucionais.

${ }_{11}^{11}$ Compare SARLET; MARIONI; MITIDIEIRO 2012, p. 207-222 com STRECK, 2007, p. 371-379.

${ }^{12}$ Cf. MAIA, 2009.

${ }^{13}$ Barroso, assim com Alexy, entende que os direitos fundamentais são expressos em princípios que, ao colidirem, devem ser ponderados com base nos princípios da razoabilidade e da proporcionalidade. Sobre o papel dos princípios constitucionais na obra do autor brasileiro, cf. BARROSO; BARCELLOS, 2008, p. 327378.

${ }^{14}$ SARMENTO, 2009, p. 113.

${ }^{15}$ SCHIER, 2005, p. 5.
} 
pluralidade de perspectivas impõe dificuldades na definição do objeto. Isso, entretanto, não constitui um empecilho insuperável para que se identifiquem alguns elementos gerais que decididamente façam parte daquilo que chamamos de Neoconstitucionalismo. A partir de uma análise das definições elaboradas por diversos autores é possível notar a existência de um padrão nas abordagens, conforme se passa a demonstrar.

Miguel Carbonell (2009, p. 198-201), ao se perguntar o que marca distintamente o Neoconstitucionalismo, elenca três elementos que caracterizariam esse fenômeno:

i) Constituições do pós-guerra que não se limitam a estabelecer as competências estatais e a separar os poderes públicos, mas também contêm normas substantivas, como os catálogos de direitos fundamentais, que condicionam a atuação do Estado por meio da ordenação de certos fins e objetivos;

ii) Práticas jurisprudenciais mais complexas a partir da construção de parâmetros interpretativos adequados para lidar com essa axiologia do texto constitucional, como as técnicas interpretativas próprias da utilização de princípios - a ponderação, a proporcionalidade, a razoabilidade, a máxima efetividade das normas constitucionais, a irradiação horizontal dos direitos fundamentais etc. o que acarreta uma explosão da atividade judicial e requer de alguma forma o ativismo judicial;

iii) Desenvolvimentos teóricos novos a partir dos textos constitucionais fortemente substantivos que não pretendem apenas explicar o fenômeno jurídico, mas também contribuir decisivamente na sua modificação.

Ao realizar um esforço semelhante de elaboração de um conceito, Daniel Sarmento (2009, p. 114-123) conclui que o reconhecimento e a defesa das mudanças operadas nos sistemas jurídicos do pós-guerra, consubstanciadas na adoção de textos constitucionais repletos de normas impregnadas de elevado teor axiológico que, por sua indeterminação semântica, demandam novos estilos hermenêuticos abertos ao debate moral, caracterizam o pensamento neoconstitucional. Outro traço característico do Neoconstitucionalismo acrescenta Sarmento - é o seu foco nos juízes, que passam a ser concebidos como guardiões das promessas civilizatórias dos textos constitucionais, apostando-se, assim, na emancipação humana pela via jurídica.

Luís Roberto Barroso (2007, p. 209-215) delineia as características do Neoconstitucionalismo a partir da reconstrução de três elementos que, a seu ver, ocasionaram 
a mudança de paradigma no direito constitucional: a) Marco histórico: constitucionalismo do pós-guerra, cujas principais características são a adoção de textos constitucionais axiológicos e a criação de tribunais constitucionais; b) Marco filosófico: pós-positivismo consubstanciado na adoção de uma postura interpretativa que busca ir além da legalidade estrita para fazer uma leitura moral do Direito por via da atribuição de normatividade aos princípios, da reabilitação da razão prática e do desenvolvimento de uma teoria dos direitos fundamentais; c) Marco teórico: o desenvolvimento de uma nova dogmática da intepretação jurídica em virtude do reconhecimento de força normativa à Constituição e da expansão da jurisdição constitucional. O autor acrescenta que todos esses elementos levam à valorização e à ampliação do papel dos juízes, notadamente da jurisdição constitucional.

Interessante a conclusão de Max Möller (2011, p. 43) que, observando a obsessão dos neoconstitucionalistas pelo Poder Judiciário, define essa doutrina “como um movimento jurídico que abarca grande parte das práticas judiciais do constitucionalismo contemporâneo e que aproxima os ordenamentos jurídicos do civil law de algumas características do direito constitucional próprio do sistema do common law”. Uma das principais facetas do common law, como se sabe, é a centralidade dos juízes na produção do Direito. A aplicação direta de princípios constitucionais - cujos conteúdos são indeterminados, permitindo o debate sobre valores morais por parte dos magistrados -, a ampliação do papel da jurisdição constitucional e a desvalorização da lei compõem o arcabouço teórico que levam o referido autor a tal conclusão.

Mostram-se relevantes também as conclusões da jurista italiana Susanna Pozzolo (2006, p. 77-79), que, ao elaborar talvez o estudo mais profundo sobre o tema, conclui que a doutrina neoconstitucional é, antes de tudo, uma política constitucional baseada em um modo específico de interpretação decorrente da adoção do modelo prescritivo de Constituição que determina certas exigências e técnicas hermenêuticas (notadamente a técnica da ponderação ou balanceamento), convertendo-se em uma prática social que redefine o objeto interpretado.

A partir dessas definições, percebe-se a existência de alguns elementos que são repetidos nos diversos trabalhos citados, permitindo a elaboração de um conceito preliminar a partir da aglutinação das ideias apresentadas. Pode-se considerar Neoconstitucionalismo como sendo uma interpretação da prática jurídica a partir da perspectiva dos juízes, em que a Constituição - editada após o restabelecimento do regime democrático - é tida como uma norma substantiva, composta primariamente por princípios, exigindo do intérprete o manuseio de técnicas especiais, notadamente a ponderação. Ou seja, o Neoconstitucionalismo é um modo específico de enxergar o Direito, no qual se valoriza o papel dos juízes na concretização 
das promessas contidas no texto constitucional, sendo inequivocamente uma teoria que busca influenciar o comportamento dos atores jurídicos. Os desdobramentos doutrinários e práticos inerentes à concepção neoconstitucional serão destrinchados mais adiante no capítulo 4.

\subsection{2 - A essência do Neoconstitucionalismo}

Não obstante inexistir uma concepção amplamente compartilhada sobre o Neoconstitucionalismo ${ }^{16}$, Susanna Pozzolo - a jurista que cunhou o termo ${ }^{17}$ - afirma que o que marca distintivamente essa corrente doutrinária é a especificidade da interpretação constitucional, que passa a ser concebida por seus adeptos como uma modalidade diferenciada da hermenêutica jurídica. De fato, conforme se percebe das definições formuladas pelos autores acima citados, um exercício mais expansivo e criativo do controle de constitucionalidade é o que possibilita essa maior interferência judicial nas demais esferas decisórias. Segundo Pozzolo, os neoconstitucionalistas compartilham a ideia de que a presença de princípios enseja uma interpretação moral da Constituição por parte dos juízes, permitindo-lhes modelar as relações sociais entre os cidadãos de modo a adequá-las aos requisitos substanciais de justiça. A partir dessa constatação, pode-se dizer que a singularidade do Neoconstitucionalismo reside na especial ênfase dada à possibilidade de modificar a sociedade por meio do Poder Judiciário ${ }^{18}$.

Tal conclusão é consequência lógica das teses defendidas pelo Neoconstitucionalismo. A decisão judicial, como bem assevera Diego Werneck Arguelhes (2005, p. 14), "é um evento que se insere na cadeia causal, na medida em que fará cessar ou permitirá a continuidade de certos comportamentos". O Poder Judiciário, portanto, tem o condão de influir e modificar o estado das coisas. Ao incentivar uma maior intervenção judicial por meio de uma interpretação mais criativa, está subentendido na doutrina neoconstitucional que se considera desejável a maior participação dos tribunais na engenharia política da sociedade. Diogo de

\footnotetext{
${ }^{16}$ A ausência de um sentido unívoco ao termo levou Miguel Carbonell a designar a sua coletânea de artigos de Neoconstitucionalismo(s) - no plural.

17 O termo "Neoconstitucionalismo" foi utilizado pela primeira vez em 1998 por Susanna Pozzolo no artigo "Neoconstitucionalimo y Especificidad de la Interpretación Constitutional" para designar uma corrente de pensamento no âmbito da filosofia do direito que adota um modelo axiológico de Constituição, compreendida por princípios que precisam ser moralmente interpretados para ganhar vida. A jurista italiana cita Ronald Dworkin, Robert Alexy, Gustavo Zagrebelsky e Carlos Santiago Nino como os precursores desse modo de pensar o direito. No Brasil, o primeiro uso da expressão deu-se em 2004 no volume nº 2 Revista do Instituto de Hermenêutica Jurídica, cujo tema era "(Neo)Constitucionalismo: ontem, os códigos, hoje, as constituições".

${ }^{18}$ Eduardo Moreira Ribeiro (2009, p. 18), um dos mais entusiasmado neoconstitucionalistas, afirma com clareza que "o Neoconstitucionalismo [...] enxerga o direito como ele pode ser: transformador".
} 
Figueiredo Moreira Neto capta bem esse espírito ao afirmar, sobre o Neoconstitucionalismo, que:

Muito concorre para essa "Constituição viva" uma nova interpretação, ao mesmo tempo integrativa, adaptativa, criativa, permanente e progressivamente dotada de característica juspolíticas, que se desenvolve nas cortes constitucionais, produzindo o que se tem denominado mutação constitucional $^{19}$.

A valorização dos princípios, a adoção de métodos mais abertos na hermenêutica jurídica, os juízos de ponderação e a constitucionalização do direito, características centrais dessa corrente doutrinária ${ }^{20}$, são os mecanismos utilizados pelos neoconstitucionalistas para interferir na realidade social. Ao contrário da maioria das regras jurídicas, que já prescrevem as suas hipóteses de incidências e consequências, as cláusulas constitucionais, em razão de sua plasticidade, permitem que a interpretação constitucional seja utilizada como instrumento privilegiado de mudança da sociedade que independe das vicissitudes do processo político. De acordo com Inocêncio Mártires Coelho, esse novo modelo de interpretação constitucional tem como inspiração o ativismo judicial da Suprema Corte norte-americana:

17. Os primórdios dessa viragem hermenêutica situam-se, a nosso ver, nas posturas e procedimentos da chamada corrente não interpretativista da práxis constitucional norte-americana, graças a cujo vitorioso desenvolvimento abandonou-se a idéia de que a Constituição é também uma lei e, assim, deve ser interpretada e aplicada com os mesmos critérios da hermenêutica jurídica geral. Por isso, pode-se afirmar que a chamada especificamente constitucional tem suas origens no ativismo judicial norteamericano, e na longevidade da Constituição dos Estados Unidos a prova da sua consistência.

18. Reconhecida, afinal, a especificidade da matéria constitucional ainda que restrita à parte dogmática das constituições -, torna-se evidente que a interpretação dita especificamente constitucional, ao fim e ao cabo, é antes de tudo uma hermenêutica de princípios, de pautas axiológicas para cuja efetividade deve-se substituir a idéia retrospectiva de interpretação pela idéia prospectiva de concretização ${ }^{21}$.

Em sentido semelhante, Luís Roberto Barroso noticia que a inspiração da prática constitucional contemporânea reside no período de ativismo da Suprema Corte estadunidense relacionado à presidência do Chief Justice Earl Warren. Durante esse período, foram julgados vários casos emblemáticos que marcaram uma guinada liberal na história do

\footnotetext{
${ }^{19}$ MOREIRA NETO, 2009, p. 213.

${ }^{20}$ A relação desses elementos foi extraída de SARMENTO, 2009, p. 109.

${ }^{21}$ COELHO, 2007, p. 116.
} 
constitucionalismo norte-americano. Sob a presidência de Warren, a Corte pôs fim à segregação racial nas escolas públicas ${ }^{22}$, assentou que o suspeito deve ser informado de seus direitos (inclusive de não produzir provas contra si mesmo) ${ }^{23}$ e determinou a redefinição de distritos eleitorais que favoreciam as oligarquias locais ${ }^{24}$, apenas para citar alguns casos. Em razão de seu valor simbólico, essas decisões deixaram um legado para as gerações futuras, que continuam a mirar esse período de ativismo para justificar os desenvolvimentos contemporâneos na teoria constitucional, conforme deixa claro Barroso:

Os dezesseis anos em que a Suprema Corte americana esteve sob a presidência de Earl Warren (1953-1969) integram, de maneira indelével, o imaginário do constitucionalismo democrático contemporâneo. Sua afirmação de igualdade entre os homens e de outros direitos individuais inspirou gerações de militantes dos direitos humanos, constitucionalistas e estadistas pelo mundo afora. Essa energia imensa, que atravessou continentes, foi gerada por uma ideia tentadora: a de que uma corte de justiça progressista pode promover a revolução humanista que o processo político majoritário não é capaz de fazer ${ }^{25}$.

O paradigma neoconstitucional, assim, baseia-se em uma tentativa de reprodução da atitude judicial bem-sucedida da Suprema Corte americana no período de ativismo liberal da Corte Warren. Todavia, vislumbrar na jurisdição constitucional um instrumento progressista gera uma série de dúvidas e questionamentos. O que tem de especial na interpretação constitucional levada a cabo nesse período que continua a inspirar constitucionalistas ao redor do mundo? Adotando-se a Corte Warren como modelo, qual a justificativa para a jurisdição constitucional? Em outras palavras, como compreender o papel dos juízes no paradigma neoconstitucional?

Para se estabelecer o pano de fundo da discussão sobre o Neoconstitucionalismo, essas perguntas serão abordadas nos próximos tópicos. Antes será reconstruído o modelo de atitude judicial que inspira essa forma de pensar. A partir de uma análise do precedente Brown, considerado o mais emblemático caso de interpretação constitucional progressista da Corte Warren, serão destrinchados os elementos que compõem essa visão transformadora da atividade jurídica (tópicos 1.2). Em segundo lugar, será discutido o significado dessa atitude progressista dentro do debate acerca da legitimidade da jurisdição constitucional (1.3). Delineados esses contornos teóricos, serão descritas, no capítulo seguinte, as principais

\footnotetext{
${ }^{22}$ Brown v. Board of Education, 347 U.S. 483 (1954)

${ }^{23}$ Miranda v. Arizona, 384 U.S. 436 (1966)

${ }^{24}$ Baker v. Carr, 369 U.S. 186 (1962)

${ }^{25}$ BARROSO, 2009, p. 324-325.
} 
características do modelo neoconstitucionalista (cap. 2), tendo por base a obra de alguns autores nacionais para, ao final, explicar porque o Neoconstitucionalismo representa uma teoria normativa - e não uma descrição - da prática jurídica (cap. 3), o que possibilitará analisar os seus impactos para o Estado de Direito.

\section{2 - Transformação social e judicial review}

De acordo com Luís Roberto Barroso (2010, p. 309), o modelo de constitucionalismo praticado nas democracias contemporâneas segue, em maior ou menor grau, o padrão estabelecido nos Estados Unidos ao longo de sua história, cujas principais características são: "(i) supremacia da Constituição, (ii) controle de constitucionalidade, (iii) supremacia judicial e (iv) ativa proteção dos direitos fundamentais".

Se historicamente essas características surgiram na ordem enumerada por Barroso ${ }^{26}$, atualmente parece não haver uma antecedência lógica dos primeiros com relação aos últimos itens. Pelo contrário, a proteção dos direitos fundamentais é normalmente apontada como uma das principais, senão a principal justificativa para a instauração de mecanismo de fiscalização jurisdicional da constitucionalidade das leis ${ }^{27}$ - notadamente para os neoconstitucionalistas o que, como consequência, pressupõe a supremacia da Constituição, que estabelece tais direitos, e do Poder Judiciário, que lhes confere efetividade, invertendo-se, portanto, a ordem lógica dos itens. A adoção de uma concepção substantiva de Constituição, portanto, é o que atualmente parece justificar os demais desdobramentos na teoria constitucional.

É curioso notar, entretanto, a partir de uma reconstrução histórica da doutrina americana do judicial review, que nem sempre a defesa de direitos foi a razão do controle de constitucionalidade. Em sua gênese, a jurisdição constitucional era tida como mecanismo de

\footnotetext{
${ }^{26}$ A supremacia da Constituição e o controle de constitucionalidade foram consequências decorrentes da decisão Marbury v. Madison, primeiro precedente em que a Suprema Corte norte-americana declarou a inconstitucionalidade de uma lei federal. Já a supremacia judicial foi declara em 1958, no julgamento do caso Cooper v. Aaron. Já a ideia de proteção ativa dos direitos fundamentais teve sua origem a partir do caso Brown v. Board of Education, de 1952, mas somente teve seus contornos consolidados nas décadas seguintes, com a decisão de outro caso emblemático - Roe $v$. Wade, em que se declarou ser constitucional o direito ao aborto - e com o desenvolvimento de teorias substantivas sobre o papel da jurisdição constitucional.

${ }^{27}$ A doutrina sobre a legitimidade do controle de constitucionalidade tem-se dividido fundamentalmente entre teorias substantivas, que entendem serem os direitos fundamentais o principal propósito da jurisdição constitucional, e teorias procedimentalistas, que defendem a intervenção judicial somente quando for para aprimorar o processo político-democrático. Para uma discussão sobre o tema, confira a crítica de Laurence $\mathrm{H}$. Tribe (1980) à concepção procedimentalista de John Hart Ely. Hans Kelsen, por outro lado, destoa dessa classificação ao conceber a jurisdição constitucional como mecanismo de manutenção de coerência e de organização das normas de sistema jurídico. Não por outro motivo, Kelsen (2003, p. 182) afirma ser "certamente no Estado federativo que a jurisdicão constitucional adquire a mais considerável importância. Não é excessivo afirmar que a idéia política do Estado federativo só é plenamente realizada com a instituição de um tribunal constitucional'. (grifo nosso) Cf. sobre o assunto o item 1.3 abaixo.
} 
manutenção da superioridade formal do texto fundamental. A Constituição, nesse sentido, era encarada, primordialmente, como norma definidora de competências e funções dos diversos órgãos governamentais $^{28}$. O caso que marca o início do controle de constitucionalidade nos Estados Unidos é um belo exemplo dessa perspectiva.

Como se sabe, o judicial review foi institucionalizado nos Estados Unidos a partir de uma construção pretoriana no caso Marbury v. Madison ${ }^{29}$, decidido em 1803. Os fatos do caso são os seguintes: William Marbury, designado pelo Presidente John Adams, em seu penúltimo dia de mandato, Juiz de Paz do Distrito de Columbia, teve sua posse negada pelo novo Secretário de Governo James Madison, indicado pelo então eleito Presidente Thomas Jefferson. Confiando em seu direito subjetivo de ver-se investido no cargo ao qual foi indicado de acordo com os requisitos legais, Marbury impetrou um writ of mandamus, com fulcro no $\$ 13^{\circ}$ do Judiciary Act de 1789, que dispunha ser da competência da Suprema Corte julgar as ações mandamentais impetradas contra autoridades federais.

O Chief Justice John Marshall, em sua decisão, após reconhecer expressamente o direito líquido e certo do impetrante ${ }^{30}$, declarou que a norma legal que concedia à Suprema Corte o poder para julgar o caso estaria em desacordo com o texto constitucional, que não previa essa jurisdição originária da Corte, extinguindo o processo sem resolução de mérito, por incompetência absoluta do juízo. A decisão em Marbury, ao declarar a inconstitucionalidade de uma regra de competência, evidencia a concepção prevalecente à época de que a Constituição serviria primordialmente para definir as funções estatais dos diversos órgãos. Nesse contexto o controle jurisdicional de constitucionalidade foi articulado pela primeira vez na história, negando-se vigência a um direito individual.

Os desenvolvimentos futuros do instituto do judicial review também não pareciam indicar que esse instrumento serviria para uma causa progressista. Nas décadas subsequentes a Marbury, nas vezes em que a Corte se arriscou a interpretar cláusulas definidoras de direitos, o resultado não foi satisfatório. Vários casos considerados desastrosos na história do

\footnotetext{
${ }^{28}$ No Federalista $\mathrm{n}^{\circ} 10$ - talvez o mais influente dentre os 85 artigos Federalistas - James Madison (1787) deixa claro que uma das principais virtudes inerente ao estabelecimento de uma Constituição é a de dividir o poder em vários níveis (federal e estadual) e em vários órgãos (Poderes Executivo, Legislativo e Judiciário) para se evitar que uma facção política tome o comando do Estado de maneira permanente, oprimindo os membros da minoria. Para Madison, a proteção das minorias adviria da divisão do poder estatal em vários núcleos da estrutura institucional, não de uma Suprema Corte encarregada de proteger direitos fundamentais.

${ }^{29}$ Marbury v. Madison, 5 U.S. 137 (1803).

${ }^{30} \mathrm{O}$ Chief Justice Marshall deixou assente que "[It] is decidedly the opinion of the court, that when a commission has been signed by the president, the appointment is made; and that the commission is complete, when the seal of the United States has been affixed to it by the [secretary of state]. [To] withhold [Marbury's] commission, therefore, is an act deemed by the court not warranted by law, but violative of a vested legal right". (grifo nosso) (apud SULLIVAN; GUNTHER, 2007, p. 2).
} 
constitucionalismo norte-americano decorreram de decisões ditas substantivas. Em Dred Scott v. Sandford ${ }^{31}$, primeiro caso em que uma lei foi declarada inconstitucional após Marbury, a Suprema Corte decidiu, em 1856, que a União não teria competência legislativa para banir a escravidão no Estado de Missouri, e que os escravos, considerados parte do patrimônio de seus senhores, não poderiam ser libertados sem a observância do devido processo legal. Sinalizou-se que o princípio constitucional do devido processo legal, interpretado de maneira substantiva, seria um empecilho à libertação dos escravos. A decisão em Dread Scott é tida como uma das razões para a eclosão da Guerra de Secessão americana ${ }^{32}$.

Igualmente catastrófico foi o caso Plessy v. Ferguson ${ }^{33}$, decidido em 1896, no qual a Corte decidiu que a décima quarta emenda constitucional norte-americana - que garante igual proteção das leis a todos os cidadãos - não proibia a segregação racial em estabelecimentos públicos, desde que houvesse instalações semelhantes para ambas as raças (doutrina do "separate, but equal"). Em seus fundamentos, a Corte concluiu que a separação entre raças não implicava reconhecimento de inferioridade da raça negra e que a adoção de medidas de segregação racial seria uma opção legítima de política pública dos Estados.

Já no início do século XX, a "Era Lochner", período de 40 anos de ativismo judicial compreendido entre os casos Allgeeyer v. Louisiania ${ }^{34}$, decidido em 1897, e West Coast Hotel Co. v. Parrish ${ }^{35}$, de 1937, também é reconhecidamente considerado um fenômeno negativo. Em vários casos, a Suprema Corte americana declarou a inconstitucionalidade de quase 200 leis que conferiam direitos sociais a trabalhadores - como o estabelecimento de salário mínimo e de jornada máxima de trabalho - sob o fundamento de que tais medidas feririam a liberdade de contratar, direito inerente ao princípio do devido processo legal. Especificamente no caso Lochner v. New York ${ }^{36}$, julgado em 1905, a Corte invalidou uma multa imposta a proprietário de uma panificadora que havia submetido seus funcionários a uma carga horária superior a 60 horas semanais, o que era proibido pela legislação estadual. Decidiu-se que o estatuto nova-iorquino interferia de maneira ilegítima no direito de contratar do patrão e de seus empregados, razão pela qual fora declarado inconstitucional.

\footnotetext{
${ }^{31}$ Dred Scott v. Sandford, 60 U.S. 393 (1856).

${ }^{32}$ Nesse sentido, Erwin Chemerinsky (2006, p. 693) afirma que: "Although the Supreme Court undoubtedly thought that it was resolving the controversy over slavery in Dread Scott v. Sandford, the decision has exactly the opposite effect. The ruling became the focal point in the debate over the slavery and, by striking down the Missouri Compromise, the decision helped to precipitate the Civil War".

${ }^{33}$ Plessy v. Ferguson, 163 U. S. 537 (1896).

${ }^{34}$ Allgeyer v. Louisiana, 165 U.S. 578 (1897).

${ }^{35}$ West Coast Hotel Co. v. Parrish, 300 U. S. 379 (1937).

${ }^{36}$ Lochner v. New York, 198 U. S. 45 (1905).
} 
Somente após o Presidente Franklin D. Roosevelt ter ameaçado, em 1937, editar uma lei para alterar a composição da Suprema Corte $^{37}$, com o claro intuito de forçar a adoção de uma orientação jurisprudencial consentânea com os princípios sociais do New Deal, o tribunal, no caso West Coast Hotel Co. v. Parrish, por 5 votos a 4, considerou constitucional uma lei do Estado de Washington que estabelecia salário mínimo para mulheres. Desde então não houve qualquer outro caso na história constitucional norte-americana em que o tribunal tenha declarado nula uma lei com base nessa faceta econômica do devido processo legal.

Percebe-se que até a década de 1940 não havia boas razões para justificar o exercício do controle de constitucionalidade com base na proteção dos direitos fundamentais. O cenário é modificado em 1954, com o julgamento do caso Brown v. Board of Education ${ }^{38}$, em que a Suprema Corte, presidida pelo Chief Justice Earl Warren, declarou inconstitucionais as políticas segregacionistas no ensino público dos Estados do Kansas, Carolina do Norte, Virgínia e Delaware, exigindo tratamento igualitário entre brancos e negros. A doutrina separate, but equal, estabelecida no caso Plessy, foi revista pela Corte, que determinou a imediata miscigenação e a integração das raças nas escolas públicas daqueles Estados. É essa decisão que serve até hoje de inspiração para o uso progressista da jurisdição constitucional mundo afora.

Em um país com graves problemas de discriminação racial, como eram os Estados Unidos na década de 1950, a decisão em Brown, ao iniciar um processo de desarticulação de valores racistas culturalmente enraizados, foi definitivamente revolucionária. É certo que o processo de mudança constitucional somente findou na década seguinte, quando o movimento dos direitos civis ganhou maciça adesão popular, o que levou à edição do Civil Rights Act, de $1964^{39}$. O papel da Suprema Corte como veículo dessa mudança ${ }^{40}$, no entanto, representou uma experiência única no constitucionalismo estadunidense por três razões.

A primeira é que, conforme salienta Bruce Ackerman (2006, p. 185-209), ao contrário das demais transformações constitucionais ocorridas até então na história americana - como, por exemplo, a Fundação, a Reconstrução e o New Deal - não havia, à época da decisão,

37 O Judicial Procedure Reform Bill, de 1937, foi um projeto de lei de iniciativa do Presidente Roosevelt que pretendia aumentar o número de Justices na mesma quantidade do número de magistrados que tivessem mais de 70 anos ainda na ativa. $\mathrm{O}$ projeto tinha o claro intuito forçar uma mudança jurisprudencial com relação a leis de cunho social que implementavam o chamado New Deal. Sobre o assunto, cf. MACKENNA, 2002.

${ }^{38}$ Brown v. Board of Education of the City of Topeka, 347 U. S. 483 (1954).

${ }^{39}$ De fato, há autores, como Michael J. Klarman (1993), que apontando que até 1964 nada de concreto havia sido efetivado para pôr fim à segregação racial nas escolas públicas, minimizam a importância da decisão judicial no caso Brown v. Board of Education.

${ }^{40} \mathrm{Na}$ ciência política, há autores que são céticos quanto à possibilidade de se promover transformação social por meio de decisão judicial. Para uma visão cética quanto ao papel do caso Brown v. Board of Education na remodelação dos valores da sociedade americana, cf. ROSENBERG, 2008, p. 39-171. 
comoção social apta a ensejar um amplo processo político de deliberação a respeito do tema. Após uma geração de intensa mobilização em virtude da crise econômica de 1929 e das duas Guerras Mundiais, os americanos retornavam a níveis normais de engajamento político. Uma mutação no entendimento dos compromissos constitucionais que levasse a sério o banimento da segregação racial não possuía apoio popular, tampouco estava no centro da agenda política. Isso se torna mais evidente quando se percebe que, mesmo após Brown, o candidato democrata à presidência dos Estados Unidos, que veio a ser eleito em 1960, John F. Kennedy, não fez da integração racial uma de suas bandeiras eleitorais ${ }^{41}$.

A segunda razão que diferencia esse momento da política constitucional americana refere-se ao fato de que, até então, somente o Poder Executivo, apoiado por um movimento partidário, havia sido o protagonista na sinalização institucional de transformações sociais paradigmáticas. Enquanto Abraham Lincoln, apoiado pelo Partido Republicano, foi a grande figura da Reconstrução Americana, Franklin D. Roosevelt, junto com o Partido Democrata, foi considerado o responsável pela implementação do New Deal. Pensar no Chief Justice Earl Warren como líder de uma revolução é algo tão inusitado quanto problemático. Inusitado por ter sido a Suprema Corte, através de uma interpretação jurídica, quem forçou a inclusão da questão política sobre a igualdade racial no centro do debate americano. Problemático pela função política desempenhada por um magistrado, de quem se espera isenção no julgamento das causas ${ }^{42}$. A ausência de um movimento partidário favorável à questão também levanta dúvidas quanto à legitimidade do encaminhamento da questão via Poder Judiciário, pois de certa forma demonstra a ausência de cidadãos engajados que abraçassem politicamente essa causa.

A terceira e derradeira distinção diz respeito ao modo peculiar como a decisão judicial foi construída. A tradição jurisprudencial americana era no sentido de que as cláusulas

\footnotetext{
${ }^{41}$ De acordo com Ackerman (2007, p. 1764-1765): “Kennedy's victory in 1960 did not to resolve the uncertainty. His public record on civil rights had been weaker than Nixon's during the 1950's, and the Democrats were traditionally the party of Jim Crow. Public opinion polls show that ordinary Americans didn't believe that the Democratic Party was more radically liberal than the Republican Party during the late 1950's and early 1960's. Only one thing was clear: if, against the odds, Kennedy chose to put power of the presidency behind the civil rights movement of Martin Luther King, Jr., he would rip apart the New Deal party that had propelled him into power".

42 Maria Lúcia Oliveira (2009, p. 41) aponta, com percuciência, as diferenças, no plano ideal, de um juízo judicial para um político. Segundo a autora: "O ponto mais relevante [...] é que a imparcialidade do julgamento político é distinta da do judicial. Isso porque a presunção da generalidade e da imparcialidade é essencial para a legitimidade das práticas políticas em sociedades igualitárias. O poder judicial tem sua imparcialidade na independência em relação ao julgamento dos atores, enquanto o julgamento político depende e tem que buscar refletir o julgamento dos cidadãos. A relação do juiz com a política deve ser indireta, não dependendo do julgamento soberano, desde que tal julgamento não tenha ainda se traduzido em direito, em leis. O juiz usa o esquema 'como se', com vistas a aceder a uma interpretação verdadeira de algo que já aconteceu, e por isso, o raciocínio judicial deve ser livre de desejos, projetos ou promessas, que são próprios do julgamento político”.
} 
constitucionais deveriam ser interpretadas com fidelidade à intenção daqueles que formularam o texto, pois à Corte era delegado o papel de guardião dos compromissos constitucionais $\operatorname{assumidos}^{43}$. No caso da décima quarta emenda, seu sentido referia-se apenas à abolição da escravidão, não à segregação racial. Além disso, havia um precedente (Plessy) válido sobre o assunto, o que impedia o avanço da Corte em direção oposta, por força da doutrina do stare decisis.

O Chief Justice Earl Warren, com o fito de esquivar-se desses empecilhos legais, após convocar uma sessão extraordinária de argumentação oral para discutir o significado original do texto constitucional, concluiu que a história da promulgação da emenda era silente quanto à educação pública e que os precedentes firmados sobre segregação racial não se referiam diretamente ao tema em questão. Em seu voto, Warren asseverou que o significado e a função da educação para o povo americano na década de 1950 era muito diferente do entendimento que se tinha sobre o assunto no século XIX, principalmente quanto ao papel essencial do Estado na formação do cidadão. Utilizando-se de resultados de pesquisas sociais aplicadas, que demonstraram que crianças negras submetidas ao regime de segregação sentiam-se inferiorizadas, Warren concluiu ser equivocado analisar o caso com as lentes do passado. Arrematou dizendo que a política de segregação racial, por trazer danos à formação individual dos negros, seria medida inconstitucional na seara da educação pública, determinando a sua imediata abolição ${ }^{44}$.

A perspectiva adotada pela Corte nesse caso foi inovadora em vários aspectos. A visão quanto ao papel da Suprema Corte é uma das mais importantes. Se tradicionalmente se acreditava que ao tribunal era confiada a função de preservação dos compromissos estabelecidos ao longo dos duzentos anos de experiência constitucional, em Brown a Corte inovou, impondo novos valores aos cidadãos americanos. Ao realizar tal empreendimento sem a existência de uma mobilização popular sobre o tema, a interpretação constitucional consubstanciou-se, nos dizeres de Ackerman (2006, p. 192), em um ato profético de

\footnotetext{
${ }^{43}$ Essa tradição encontra eco atualmente nas teorias chamadas de originalistas, cujo principal defensor é o Justice Antonin Scalia (1997, p. 3-47).

${ }^{44}$ Como bem salienta Jack M. Balkin (2004, p. 1563-1568), a decisão em Brown limitou-se à educação pública como estratégia para distingui-lo dos casos anteriores em que a Corte havia considerado legítima a segregação em espaços públicos. No entanto, o princípio estabelecido nesse caso passou por várias mutações interpretativas, sendo certo que, posteriormente, a Suprema Corte reconheceu o precedente como estabelecendo uma regra geral antidiscriminatória, como em Loving v. Virginia (388 U.S. 1), e até mesmo como impondo ao Estado a obrigação de apagar os vestígios da discriminação racial, como em Green $v$. School of New Kent County (391 U.S. 430). Mais recentemente, o entendimento da Corte é de que Brown não proíbe atos estatais neutros, mas apenas aqueles baseados em uma distinção racial, ainda que a política adotada produza de fato resultados diferenciados com relação às raças, conforme restou decidido em Washington v. Davis (426 U.S. 229).
} 
inspiração política: "Ele é profético quando sua crítica de injustiça social se inspira no senso profundo da moral; é profético, ainda, pois a Corte pôde prever o sucesso político dessa crítica moral”.

Outro aspecto importante relacionado à decisão em Brown diz respeito ao modo peculiar como os princípios constitucionais foram articulados. Ao invés de buscar o significado histórico do compromisso constitucional estabelecido no princípio da igualdade, a Corte interpretou a décima quarta emenda como um princípio abstrato, cujo conteúdo adaptou-se à necessidade moral do caso em análise. Ou seja, fez-se uma leitura moral da Constituição, a partir do princípio da igualdade, para utilizar a difundida expressão cunhada por Ronald Dworkin (1996, p. 1-38).

O fim do racismo institucionalizado nos Estados Unidos fez com que Brown v. Board of Education adquirisse a condição de superprecedente ${ }^{45}$, servindo de inspiração para as gerações futuras de advogados e juízes. A utilização progressista da jurisdição constitucional passou a fazer parte do imaginário dos juristas e da população em geral, servindo de ideia motriz para inúmeras outras decisões liberais, como Roe v. Wade ${ }^{46}$ e Lawrence v. Texas ${ }^{47}$. Desde então, a teoria constitucional nunca mais foi a mesma. Questões sobre arranjos institucionais, formas de governo e modo de aquisição e exercício do poder - que eram os principais temas abordados pelos estudiosos do direito constitucional - passaram a dividir a atenção com teorias da interpretação e de legitimidade da jurisdição constitucional.

O Neoconstitucionalismo, como não poderia deixar de ser, absorve e reverbera a maior parte dos elementos característicos da decisão em Brown. Para essa corrente de pensamento, o Poder Judiciário apresenta-se como importante veículo de transformação da sociedade, principalmente em questões que, mercê de sua importância, não são abordadas pelo processo majoritário por falta de mobilização política apta a ensejar um amplo debate nacional a respeito do tema. Essa capacidade de interferir na realidade social se dá por meio de uma interpretação progressista de princípios constitucionais - que possuem alta carga de abstração - conferindo à jurisdição constitucional a função profética de indicar o caminho mais correto a ser adotado pela sociedade. Em linhas gerais, a crítica moralista da sociedade realizada pela

\footnotetext{
${ }^{45}$ Bruce Ackerman (2007, p. 1750-1751) utiliza esse termo para designar algumas decisões judiciais que, pela sua importância no constitucionalismo americano, se incorporaram ao cânon constitucional, nivelando-se ao texto constitucional e a suas emendas.

${ }^{46}$ Roe v. Wade, 410 U.S. 113 (1973). Nesse caso, a Suprema Corte reconheceu que a prática do aborto seria constitucional em face do direito à privacidade inerente ao devido processo legal substantivo.

${ }^{47}$ Lawrence v. Texas, 539 U.S. 558 (2003). Nesse precedente declarou-se inconstitucional uma lei do Estado de Texas que considerava crime relação sexual entre pessoas do mesmo sexo.
} 
Suprema Corte americana no caso Brown é o modelo de atuação judicial que inspira as teorias neoconstitucionais.

\subsection{1 - O Realismo Jurídico e a construção jurídica do modelo Brown}

Antes de adentrar no tópico sobre as justificativas para o exercício progressista da jurisdição constitucional, revela-se oportuno mencionar outra característica relacionada ao contexto filosófico em que Brown v. Board of Education foi decidido. Na década de 1930, muito em virtude da atitude da Suprema Corte americana de invalidar inúmeras leis de cunho social, surgiu o movimento intelectual denominado Realismo Jurídico ${ }^{48}$, cujo principal escopo era o de atacar a ideia difundida de que os juízes aplicavam as regras e os princípios jurídicos de maneira mecânica e imparcial. Juristas como Oliver Wendell Holmes Jr., Karl Llewellyn e Jerome Frank denunciavam que o ato de julgar era algo muito mais subjetivo e complexo do que se imaginava e que, além do material jurídico, fatores sociais e culturais influenciavam no resultado final dos casos.

De acordo com Purcell Jr. (1969, p. 426), o alvo dessa nova corrente de pensamento era o formalismo jurídico, teoria dominante até a década de 1920 que defendia a tese de que as decisões judiciais nada mais seriam do que aplicações silogísticas de regras e precedentes historicamente determinados. Para a doutrina tradicional, a concepção de direito natural derivada dos séculos XVII e XVIII servia como fundamento moral das decisões, enquanto o trabalho de William Blackstone sobre a common law fornecia os princípios básicos da interpretação judicial. Sob essa perspectiva, os juízes teriam a função de descobrir as regras e os precedentes apropriados para aplicá-los objetivamente aos casos concretos. A projeção do formalismo jurídico no campo do direito constitucional desembocou na malfadada "Era Lochner”, já discutida, em que a Suprema Corte americana, abraçando os valores econômicos do laissez-faire, declarou a inconstitucionalidade de inúmeras leis associadas ao New Deal. É

\footnotetext{
${ }^{48}$ Edward McWhinney (1957, p. 116) afirma que a derrota final da doutrina laissez-faire na Suprema Corte, em 1937, representou a maior conquista do Realismo Jurídico. Como bem salienta Edward A. Purcell Jr. (1969, p.436-437): "Frank, Oliphant, Arnold, Douglas, and Felix Cohen were all ardente New Dealers who shared a Strong hostility to the method of juristic reasoning that struck down social welfare laws and wrought that they considered great human injustices. Most of the other realists expressed equally strong disapproval of the social and economic situation of the thirties. (...) Though the theoretical problems the realists raised left them open to bitter attack, the obtuse formalism of American constitutional interpretation throughout the first third of the twentieth century helped drive them to their extreme positions. The manifest human needs created by the depression further convinced them of the need for a more realistic and flexible legal theory to attain what they considered a truly democratic society".
} 
contra essa herança jurídica que se volta o Realismo Jurídico, que na verdade surge num contexto acadêmico mais amplo.

Nas primeiras décadas do século XX, o desenvolvimento bem-sucedido das ciências naturais gerou uma nova atitude na vida intelectual norte-americana, que passou a aplicar o método empírico também nas ciências sociais. Esse processo iniciou-se no campo da psicologia, área do conhecimento em que foram desenvolvidas influentes pesquisas acerca do comportamento humano (behaviorismo). Logo em seguida, o empirismo ingressou no campo da filosofia. William James e John Dewey, ao desenvolverem a corrente filosófica pragmática, pregavam, com bastante influência, a utilização do método científico para compreender e resolver os mais diversos problemas da sociedade. Com a difusão de tais ideias passou-se, como regra geral, a analisar empiricamente as causas e as consequências dos atos humanos, tendo como objeto de estudo a realidade social. Qualquer autoridade baseada em uma moralidade metafísica ou em uma verdade histórica, por não poder ser falseada, foi colocada em xeque. Todo argumento necessitava ser cientificamente comprovado. É no meio dessa efervescência intelectual que surge o Realismo Jurídico, questionando os métodos utilizados pelo ensino jurídico tradicional ${ }^{49}$.

Para os realistas, as decisões judiciais não poderiam ser vistas como uma mera aplicação mecânica de normas e princípios historicamente preestabelecidos. Influenciados pelo empirismo, eles também questionavam a autoridade moral e histórica que supostamente neutralizaria o discurso jurídico. Demonstrando a existência de inúmeras contradições nos precedentes e na legislação, esses autores denunciavam que a escolha de um determinado resultado jurídico representaria, inequivocamente, um ato de vontade do juiz, cuja atuação é influenciada por inúmeros aspectos sociais e culturais. Concluíam, assim, os realistas, que o Direito, longe de ser algo objetivo, é parte integrante da realidade social e que o juiz é condicionado à sua experiência pessoal ${ }^{50}$.

O Realismo Jurídico defendia que, tendo em vista sempre haver várias soluções jurídicas possíveis para um caso concreto, deveria adotar aquela que produzisse o melhor resultado social possível. Se, por exemplo, a aplicação jurídica dos princípios econômicos do laissez-faire estava causando estragos sociais, cumpriria ao cientista social elaborar nova postura interpretativa que gerasse boas consequências. É nesse contexto que as pesquisas

\footnotetext{
49 Sobre o assunto, cf. BURRUS, 1962, 37-40.

${ }^{50}$ Wayne Morrison (2006, p. 9) corrobora esse entendimento ao caracterizar Realismo Jurídico da seguinte forma: "[E]xiste uma tradição do realismo jurídico que procura estabelecer o direito como parte integrante de um mundo social inevitavelmente complexo. Nessa tradição, dizer a 'verdade do direito' é parte integrante do dizer a "verdade da realidade social'”.
} 
empíricas ganham relevância para os realistas, por permitirem ao juiz conhecer de antemão os impactos relativos aos diversos posicionamentos possíveis. Essa teoria jurídica, portanto, tira o foco das normas jurídicas e da construção histórica dos precedentes, concentrando-se, basicamente, na análise dos efeitos das decisões ${ }^{51}$.

A mensagem que os autores realistas estavam passando era a de que o Direito, antes de tudo, por ser uma construção humana voltada para a satisfação das necessidades sociais e a resolução de conflitos, é algo contingencial, fruto das escolhas pessoais dos envolvidos em sua construção. Não há nenhuma verdade metafísica ou princípio moral universal que lhe fundamente. Contrariamente ao que defendiam os formalistas, para os realistas o fenômeno jurídico não estava imune ao contexto político-econômico em que opera, devendo, na verdade, amoldar-se às circunstâncias em que os casos são decididos. É nesse sentido que Holmes afirma que " $a$ vida do Direito não tem sido a lógica, tem sido a experiência", completando que Direito "não pode ser tratado como se contivesse apenas os axiomas e as regras de um livro de matemática ${ }^{, 52}$. Em uma sociedade em constante transformação, a flexibilização das normas jurídicas tornava-se uma medida necessária para acomodar as necessidades emergentes ${ }^{53}$. Era exatamente esse aspecto que os realistas tentavam enfatizar: abandonando-se as amarras formalistas, seria possível reformar a sociedade por meio do Direito $^{54}$.

A decisão em Brown herda vários elementos da tradição realista. A utilização, como razão de decidir, de pesquisas psicológicas empíricas que demonstravam que as crianças negras em regime de segregação sentiam-se inferiores às brancas é apenas o indício mais

\footnotetext{
${ }^{51}$ Oliver Wendell Holmes Jr. (2009, p. 22) deixa claro esse seu sentimento ao expressar que: "For the rational study of the law the black-letter man may be the man of the present, but the man of the future is the man of statistics and the master of economics. (...) I look forward to a time when the part played by history in the explanation of the dogma shall be very small, and instead of ingenious research we shall spend our energy on study of the ends sought to be attained and the reasons for desiring them".

52 Tradução livre de HOLMES JR., 2005, p. 1.

${ }^{53}$ Purcell Jr. (1969, p. 428) explica este ponto da seguinte forma: "The inconsistencies between the practices of a rapidly changing industrial nation and the claims of a mechanical juristic system had grown so acute by the 1920 's that in the minds of an increasing number of individuals the old jurisprudence could no longer justify and explain contemporary practice. It had become clear, Judge Cardozo declared in 1932, that 'the agitations and the promptings of a changing civilization' demanded more flexible legal forms and demanded equally 'a jurisprudence and philosophy adequate to justify the change,".

${ }^{54}$ Brian Z. Tamanaha (2010, p. 94) afirma que o Realismo Jurídico não era um movimento apenas desconstrutivo, mas principalmente dedicado ao aprimoramento do Direito e da sociedade. Segundo o autor: "The realists believed in the law and fervently labored to improve it. Llewellyn unabashed proclaimed his 'faith about the Good in this institution of our law'; and he waxed poetically on 'the esthetics of certain legal arts I deeply love'. In defense of the realists, Eugene Roscow, the dean of Yale Law School who knew many of the key players, remarked that 'the legal realists were among our most devoted and effective reformers, both on law and of society'. Jerome Frank confessed, 'I am - I make no secret of it - a reformer'. (....) Their collective insistence that law is a powerful instrument to serve the social good, and their sustained effort to bring this about, bespeaks their abiding faith in the law".
} 
óbvio dessa ligação. A forma como a decisão foi cunhada, ignorando o passado histórico da décima quarta emenda constitucional e afastando a doutrina firmada no precedente Plessy com vistas a reformar um mal social através do Direito tem muito a ver com a forma de raciocinar dos autores realistas: não se buscou apoio no material jurídico existente para legitimar a decisão, mas nas boas consequências que seriam produzidas a partir dela. A interação Direito e realidade social é levada ao extremo em Brown: a Corte tinha consciência de que estava agindo positivamente na construção de uma nova configuração social.

O legado realista também está presente no Neoconstitucionalismo. Ao endossar o modelo Brown como o paradigma de atuação dos juízes, absorve-se uma série de propriedades que circundam essa decisão. Da mesma forma que os realistas questionam o método formalista de interpretação, os neoconstitucionalistas afirmam que os métodos hermenêuticos tradicionais não são mais úteis para interpretar a Constituição. Do mesmo modo que os realistas duvidam do conhecimento histórico dos precedentes, os neoconstitucionalistas são céticos quanto às razões positivadas nos textos legais. Ambos duvidam da possibilidade de se utilizarem as normas jurídicas como parâmetros para decidir os casos e possuem pretensões prospectivas de modificar a realidade social.

\section{3 - O controle de constitucionalidade e a questão da legitimidade}

Como se percebe, o controle de constitucionalidade é o mecanismo por excelência mediante o qual o Poder Judiciário pode interferir na realidade social. A revisão dos atos legislativos e administrativos, tendo por base cláusulas constitucionais, permite ao juiz avaliar o conteúdo das ações dos demais órgãos estatais e corrigi-las, caso entenda ser apropriado. Atualmente, nada está imune ao crivo do Poder Judiciário. Desde temas aparentemente irrelevantes - a forma de pesagem de botijões de gás ${ }^{55}$, por exemplo - até ponderações científicas complexas - como a possibilidade de uso de derivados de amianto na construção civil $^{56}$ - passando por questões eminentemente políticas e morais, tudo é apreciado em seu mérito pelos tribunais, que podem reconsiderar as decisões já tomadas pelos outros órgãos ${ }^{57}$.

\footnotetext{
55 Supremo Tribunal Federal, Ação Direta de Inconstitucionalidade nº. 855, Min. Rel. Octavio Gallotti, julgada em 06/03/08, acórdão publicado no DJ-e de 27/03/09.

${ }^{56}$ Supremo Tribunal Federal, Medida Cautelar em Ação Direta de Inconstitucionalidade no. 3.937, Min. Rel. Marco Aurélio, julgada em 04/06/08, acórdão publicado no DJ-e de 10/10/08.

${ }^{57}$ Eduardo Mendonça (2010) defende que a Corte Constitucional representa um locus deliberativo em que as decisões dos demais poderes passam por um crivo argumentativo de legitimidade. Assim, a rediscussão no Judiciário das mesmas questões que foram tratadas pelo Legislativo e pelo Executivo não representaria uma distorção do sistema, mas sim um plus de legitimidade, sendo quase uma necessidade institucional.
} 
O que justifica no plano teórico o deslocamento da esfera decisória sobre essas questões para o Judiciário em uma sociedade dita democrática, como a brasileira? Qual a razão de se conferir aos tribunais o poder de transformar a realidade social por meio da interpretação constitucional? Como visto acima, até a decisão em Brown, a ideia de que cumpre à jurisdição constitucional proteger direitos não se mostrava autoevidente. $O$ entendimento dominante era de que o tribunal constitucional deveria manter os compromissos constitucionais assumidos no âmbito político, independentemente de seus méritos ${ }^{58}$. Ao ler a décima quarta emenda de maneira abstrata para fazer uma crítica moral da sociedade estadunidense, a Suprema Corte rompe com esse pensamento e inicia uma nova prática, cujos contornos ainda não estão claramente definidos ${ }^{59}$. O tema da legitimidade da jurisdição constitucional ainda se mostra espinhoso. As respostas às questões formuladas são variadas e muitas vezes complementares.

Quatro argumentos frequentemente utilizados nesse tipo de discussão merecem uma maior atenção. O primeiro vincula-se à ideia de vontade popular, o segundo refere-se a um suposto conhecimento técnico adquirido pelos juízes, o terceiro enxerga no bom funcionamento do processo democrático o objetivo do controle de constitucionalidade, enquanto o quarto preocupa-se com a proteção de direitos fundamentais. Em todos os casos, a possibilidade de intervenção judicial transformadora mostra-se presente, o que faz com que todas as alternativas sejam potenciais candidatas à explicação do fenômeno da expansão do Poder Judiciário.

\footnotetext{
${ }^{58}$ A doutrina constitucional mais influente até Brown era um texto de James B. Thayer, publicado em 1893 na Harvard Law Review, em que o autor defendia que um ato somente poderia ser declarado inconstitucional se afrontasse de maneira inequívoca o texto constitucional. Segundo Thayer, os tribunais, ao exercerem o controle de constitucionalidade, realizariam uma atividade jurídica e não política, razão pela qual não poderiam invalidar qualquer erro legislativo, mas somente os eivados de vícios constitucionais grosseiros. Essa doutrina, com ampla disseminação acadêmica, influenciou o modo de pensar dos juristas estadunidenses durante várias gerações, contendo o ativismo judicial. Não por outro motivo, as principais obras de direito constitucional americanas somente vieram a ser publicadas após Brown v. Board of Education, quando a teoria constitucional teve que se reinventar para acomodar uma nova forma de pensar a jurisdição constitucional. Sobre a influência de Thayer no pensamento dos Justices da Suprema Corte, cf. MENDELSON, 1978.

${ }^{59}$ Jed Rubenfled (2005, p. 5-6) aponta que o problema da justificatica da jurisdição constitucional reside exatamanete na ausência de uma teoria que una de forma coerente todos os propósitos subjacentes às variadas decisões e teorias da interpretação. Nas palavras do autor, "constitutional law presentes us with a body of decisions unable to account for its own existence. In this unnacounted-for interpretative system, our justices periodically effect revolutionary doctrinal transformations. Five justices may be doing so again today. But we have no criteria by which - no framework with which - to evaluate these episodes of radical interpretation".
} 


\subsection{1 - O argumento da vontade popular}

Os adeptos ao argumento da vontade popular acreditam que os juízes fazem uma espécie de elo entre a sociedade e o ordenamento jurídico, diminuindo o abismo existente entre os anseios sociais e o Direito. De acordo com essa concepção, as normas jurídicas não conseguem refletir os valores da sociedade, seja por vícios no processo legislativo ou em virtude de uma realidade social cambiante, sendo necessária a intervenção dos tribunais por meio do controle de constitucionalidade para reaproximar a ordem fático-social da jurídica ${ }^{60}$. De um lado, cidadãos alienados e impotentes; do outro, agentes públicos egoístas impondo suas preferências sobre a sociedade; e ao centro, juízes capazes de refletir com fidelidade a vontade do povo, filtrando o resultado do processo político. Eis a essência dessa forma de pensar a relação entre a Corte Constitucional e a sociedade.

Quando o Ministro Joaquim Barbosa argumenta, por exemplo, que as alegações de inconstitucionalidade da lei da Ficha Limpa "decorrem de uma interpretação limitada da Constituição Federal, que privilegia uma minoria de ocupantes de cargos eletivos em detrimento de toda a sociedade que anseia pela moralização na política" ${ }^{\text {"61 }}$, parece estar endossando de alguma forma o argumento da vontade popular. A mensagem que ele passa é a de que as proposições jurídicas, para serem legítimas, devem guardar consonância com as aspirações do povo.

Essa posição, no entanto, encontra uma série de dificuldades. Em uma sociedade marcada pela pluralidade de perspectivas, decobrir quais são os verdadeiros valores compartilhados pela sociedade em determinado momento não é tarefa fácil. $\mathrm{O}$ fato de o intérprete discordar do conteúdo de uma norma jurídica não significa necessariamente que há um distanciamento entre o Direito e aquilo que a sociedade pensa, mas evidencia a existência de discordância entre o que magistrado entende ser correto e o que diz a norma. Incumbir aos tribunais a tarefa de atualizar o ordenamento jurídico de modo a adequá-lo ao sentimento popular gera questionamentos quanto à legitimidade democrática. Isso porque se estaria privilegiando o ponto de vista de alguns poucos membros do Judiciário em detrimento da opinião dos demais cidadãos, que dificilmente se sentem representados por juízes. Acaba-se

\footnotetext{
${ }^{60}$ Aharon Barak (2006, p. 3 e 11), ex-magistrado da Suprema Corte Israelita, parece defender ponto de vista semelhante, para quem: "The law regulates relationships between people. It reflects the values of society. The role of the judge is to understand the purpose of law in society and to help the law achieve its purpose". E completa o jurista: "The role of a judge is to help bridge the gap between the needs of society and the law without allowing the legal system to degenerate or collapse into anarchy".

${ }^{61}$ Supremo Tribunal Federal, Ação Direta de Constitucionalidade no. 29, Min. Rel. Luiz Fux, julgada em 16/02/12, decisão ainda não publicada. Voto do Ministro Joaquim Barbosa, p. 6, disponível em http://www.stf.jus.br/arquivo/cms/noticiaNoticiaStf/anexo/ADC29.pdf. Acesso em 20/06/12.
} 
substituindo um problema por outro: como, afinal, controlar se as decisões dos tribunais estão em consonância com os sentimentos compartilhados pelos membros da sociedade?

Além disso, por mais que as normas jurídicas nasçam de escolhas eminentemente políticas, espera-se que a atividade judicante seja isenta e imparcial. Há um sentimento geral de que os juízes devem decidir os casos de acordo com o direito das partes, não com base na opinião pública $^{62}$. A necessidade de aderência do julgador ao texto legal é um dos requisitos que normalmente se associa ao Estado de Direito. A ideia de reencontro entre o Direito e os anseios da sociedade por meio da interpretação constitucional exigiria, no mínimo, maior elaboração e refinamento teórico para essa postura não ser identificada como uma espécie de populismo judicial $^{63}$.

Há um derradeiro obstáculo ao argumento da vontade popular. Conforme se demonstrou, o caso Brown v. Board of Education tornou-se célebre exatamente por romper com o sentimento racista compartilhado por grande parte da população norte-americana, impondo uma nova configuração social. Trata-se daquilo que Alexander M. Bickel (1986) denominou de dificuldade contramajoritária da Suprema Corte $^{64}$, em que leis aprovadas pelas maiorias políticas são declaradas inconstitucionais juízes não eleitos em tribunais. Vencer o determinismo social parece ser um dos objetivos da jurisdição constitucional. Ao vincular o controle de constitucionalidade aos valores prevalecentes na sociedade, nega-se a possibilidade de haver decisões emancipatórias, como em Brown. Isso porque os pontos de vista insulares e minoritários acabariam não sendo representados pela vontade popular, que em última análise seria identificada com a vontade da maioria.

\footnotetext{
${ }^{62}$ Esse sentimento foi externado pelo Presidente da Central Única dos Trabalhadores (CUT), Vargas Freitas, que ameaçou convocar os sindicalistas a protestarem contra eventual "decisão política" do Supremo Tribunal Federal no caso do Mensalão. "Não pode ser um julgamento político. Se isso ocorrer, nós questionaremos, iremos para a rua", afirmou Freitas ao jornal Folha de S. Paulo. In: http://www1.folha.uol.com.br/poder/1117248-cut-diz-que-ira-as-ruas-para-defender-reus-do-mensalao.shtml (acesso em 07/08/2012)

${ }^{63} \mathrm{O}$ termo "populismo judicial" tem sido empregado pelo Ministro Gilmar Mendes em várias entrevistas para designar a atitude de magistrados que, constrangidos pela mídia, principalmente em casos criminais, julgam de acordo com a opinião pública - e não com base nas normas legais. Sobre o assunto, cf. ULHÔA; BASILE (2010). O termo populismo também é utilizado por Cass Sunstein (2009, p. 123-184) para designar uma concepção judicial que defende a aceitação e o respeito dos magistrados aos valores compartilhados pela maioria da sociedade, adotando a estratégia de humildade judicial.

${ }^{64}$ Conforme explica o referido autor, "when the Supreme Court declares unconstitutional a legislative act or the action of an elected executive, it thwarts the will of representatives of the actual people of the here and now; it exercises control, not in behalf of the prevailing majority, but against it”. (BICKEL, 1986, p. 16-17).
} 


\subsection{2 - O argumento da competência funcional}

Outra perspectiva igualmente difundida aponta as qualidades técnicas dos juízes como elementos chaves para compreender o porquê da proeminência dos tribunais nas sociedades contemporâneas. Uma versão bastante arrojada desse argumento da competência funcional fundamenta-se em uma nova configuração do princípio da separação de poderes que leva em consideração o nível de desempenho das instituições para a alocação das diversas funções estatais.

Segundo essa perspectiva, a concepção de Montesquieu seria uma concepção formalista da separação de poderes, em que as funções do Executivo, do Legislativo e do Judiciário seriam estanques e predeterminadas. Ocorre que, segue o argumento, “a separação estrita dos poderes [como proposto na doutrina clássica]... envolve um grau intencional de ineficiência" "65, o que teria levado a um novo arranjo institucional desse princípio ao longo do último século. Em virtude da necessidade de maior intervenção governamental na economia e nas relações intersubjetivas em uma sociedade cada vez mais complexa, o Estado assumiu novas funções que não se encaixavam adequadamente na rígida classificação de Montesquieu, exigindo uma releitura da separação dos poderes a partir destes parâmetros:

Em primeiro lugar, o princípio da "separação negativa" enxerga o governo como uma bomba tão potente que a nenhum órgão isolado pode ser confiada a sua fórmula. Ao contrário, a fórmula é dividida em pedaços na esperança de que, se a nenhum órgão for permitido ter a posse de mais de um pedaço da fórmula, nenhuma pessoa ou grupo irá obter o controle da bomba. A separação negativa exige que as funções governamentais sejam cuidadosamente elaboradas e divididas em órgãos distintos como uma medida profilática contra ameaças à liberdade individual.

Em segundo lugar, o princípio da "separação funcional" tem como escopo alocar as funções governamentais nos órgãos que possuem melhores condições para desempenhá-las bem. Tendo em vista que os órgãos são definidos de forma radicalmente distintas, eles normalmente apresentam diferentes qualidades e defeitos funcionais. Por exemplo, tarefas que demandam um grau de compromisso vão ser mais bem desempenhadas por um tipo de estrutura, enquanto outra pode ser mais adequada para fazer valer o compromisso, independentemente dos sacrifícios envolvidos em sua execução. A separação funcional, portanto, informa que cada função governamental deva ser concedida ao órgão melhor adaptado para o seu desempenho. Procura-se, então, promover a eficiência governamental ${ }^{66}$.

Assim, independentemente das funções originariamente designadas a cada um dos poderes pela doutrina clássica, o que realmente importa nessa nova perspectiva é a habilidade

\footnotetext{
${ }^{65}$ Tradução livre de NEUBORNE, 1982, p. 366.

${ }^{66}$ Tradução livre de NEUBORNE, 1982, p. 372.
} 
de cada órgão estatal para desempenhar a função que lhe é designada. As agências reguladoras, por exemplo, passaram a exercer poder normativo em razão do conhecimento técnico envolvido nas questões a elas submetidas e da necessidade de rapidamente responder às mudanças conjunturais. O Legislativo, por não ser institucionalmente o locus mais adequado para responder às necessidades inerentes à atividade regulada, transfere parte de sua competência a outro órgão que possui mais capacidade para exercer essas funções.

O que importa para os adeptos do argumento da competência funcional é que a atividade estatal seja dividida em várias esferas de atuação (separação negativa) e que as funções sejam designadas aos órgãos que tenham as melhores condições de cumpri-las satisfatoriamente (separação positiva). Trata-se de uma visão eminentemente pragmática da máquina estatal, focando-se mais nos resultados que cada estrutura institucional tem capacidade de produzir do que nas formas idealizadas por teóricos.

Essa linha de pensamento foi fortemente influenciada pela chamada "escola do Legal Process", desenvolvida por Henry Hart e Albert Sacks na Faculdade de Direito de Harvard durante a década de 1950. Segundo esses autores, os processos de criação e aplicação do Direito são divididos verticalmente entre os Estados e a União Federal, e horizontalmente entre os diversos órgãos estatais, sendo a interação de todos os procedimentos um mecanismo dinâmico de criação de políticas públicas. Em outras palavras, todos os agentes governamentais devem ser considerados partícipes no desenvolvimento do Direito na medida de sua competência, não sendo mais possível falar em função específica de cada um dos poderes.

Para Hart e Sacks, a forma como a sociedade dividiu o agir coletivo - e não a função designada a priori pela teoria da separação dos poderes - torna-se relevante para aferir a legitimidade da decisão tomada em nome da sociedade. Uma vez resolvida uma questão por quem é institucionalmente designado para tanto, cumpre aos demais órgãos obedecer a ela e complementá-la no limite de sua competência, ainda que discordem do resultado produzido pela instância especializada.

Com o objetivo de determinar a divisão de tarefas governamentais, Hart e Sacks elaboram, então, o princípio do ajuste institucional, segundo o qual os procedimentos de tomadas de decisão devem ser alocados nas instituições que sejam mais bem adaptadas para lidar especificamente com as questões que se pretende solucionar. A legitimidade da decisão decorre exatamente da certeza de que se obedeceu ao procedimento do órgão que é mais 
propenso a gerar conclusões satisfatórias sobre o tema em debate. Enfim, a capacidade institucional é o que define o papel de cada órgão ${ }^{67}$.

No modelo de Hart e Sacks, a delegação de competência decisória para o Poder Judiciário se dá por via dos termos linguísticos utilizados pelo legislador ao cunhar as cláusulas legais. Caso se conclua que determinada questão deva ser resolvida no momento da aplicação da norma, estabelecem-se textos mais abertos, como as cláusulas gerais ${ }^{68}$ e os conceitos jurídicos indeterminados ${ }^{69}$, que dão maior espaço de conformação aos juízes para construírem a política pública em jogo ${ }^{70}$. Por outro lado, caso se entenda que o Legislativo possui mais capacidade institucional para decidir sobre determinado tema, são estabelecidas regras jurídicas específicas que conferem margem restrita de discricionariedade aos magistrados ao interpretá-las. Para os referidos autores, o importante é que, uma vez decidida a questão pelo órgão institucionalmente designado para tanto, não haja subversão ou desobediência por parte dos demais atores. ${ }^{71}$

Ocorre que, no campo do direito constitucional, em virtude dos inúmeros e muitas vezes contraditórios princípios plasmados no texto fundamental, toda questão pode acabar sendo transferida para os tribunais por meio do controle de constitucionalidade. No caso brasileiro, a ambição do texto constitucional torna irrelevante qualquer tentativa de justificar a transferência do centro decisório de certas questões para os juízes com base no argumento da competência funcional, pois não há escrutínio razoável em nosso sistema para distinguir quais

${ }^{67}$ William Eskridge Jr. e Philip P. Frickey (1994, p. 2033) resumem a doutrina do denominado Legal Process desta forma: "The key to good government is not just figuring out the best policy, but also identifying which institutions should be making which decisions and how the different institutions can collaborate most productively".

68 Segundo Luciana Penteado (2005, p. 152), cláusula geral: "São regras, dotadas de tal grau de generalidade na sua redação, ora na fattispecie, ora na estatuição, e em certas circunstâncias em ambas, que permitem de modo mais claro a construção da norma do caso, porque, por meio delas, não estão claramente definidos os casos que serão regulados elou a forma em que se dará a regulação. A intenção normativa está ainda mais oculta no texto da cláusula geral. São autorização para produção de direito novo (normas secundárias), dentro do contexto valorativo".

${ }^{69}$ Fredie Didier Jr. (2009, p. 67) diferencia os conceitos jurídicos indeterminados das cláusulas gerais, afirmando que no primeiro caso há predefinição dos efeitos jurídicos das normas, enquanto no segundo também os efeitos devem ser elaborados pelo magistrado ao interpretar a lei. Isto é, as cláusulas gerais, por serem mais vagas, demandam uma maior atividade normativa por parte do juiz.

${ }^{70}$ Como explicam Eskridge Jr. e Flickey (1994, p. 2044): "Hart and Sacks then explored the ways in which legislative policy choices Interact with implementional discretion. One way is through the choice of rules versus standards. If the legislature decides to deal with the problem through specific rules, it expresses confidence that it has sufficient information to solve the social problem. If the legislature is unsure how to proceed, it will adopt a standard, which essentially delegates rulemaking responsibilities to courts, agencies, or private institutions.

${ }^{71}$ Hart e Sacks (1994, p. 146-147) assim expressam esta ideia: "The first responsibility of an official who is charged with the duty of resolving a controverted issue about the meaning of a general directive arrangement, it is suggested, is to make as sure as he can that the claimed uncertainty is a real one which he actually has power to resolve. Respect for the principle of institutional settlement demands this. What a legislature has duly determined ought not to be set at naught by any other agency or person. What earlier judicial decisions have duly settled ought not to come unsettle". 
questões são mais bem resolvidas por meio de um processo judicial do que pelo processo político. Dito de outra forma, não há decisão que fuja do controle do Poder Judiciário, que sempre pode revê-la com base em parâmetros constitucionais. As reflexões de Oscar Vilhena Vieira parecem captar bem o estado das coisas:

[A] Constituição transcendeu os temas propriamente constitucionais e regulamentou pormenorizada e obsessivamente um amplo campo das relações sociais, econômicas e públicas, numa espécie de compromisso maximizador. Este processo chamado por muitos colegas de constitucionalização do direito, liderado pelo Texto de 1988, criou, no entanto, uma enorme esfera de tensão constitucional e consequentemente gerou uma explosão de litigiosidade constitucional. A equação é simples: se tudo é matéria constitucional, o campo de liberdade dado ao corpo político é muito pequeno ${ }^{72}$.

No Brasil, o argumento da competência funcional normalmente é associado ao fato de que, na maior parte dos casos, os juízes investem-se no cargo por meio de concurso público de provas e títulos. Duas são as possíveis defesas dessa espécie de raciocínio. Em um primeiro plano, pode ser dito que, como os problemas constitucionais são questões jurídicas, nada mais justo que eles sejam decididos por pessoas que comprovadamente tenham conhecimento jurídico para tanto. A força desse argumento é temperada com o que já foi mencionado: em razão da abertura do texto constitucional, várias questões que não necessariamente são mais bem decididas por juízes - questões eminentemente políticas ou econômicas, por exemplo passam injustificadamente para a esfera judiciária, o que mina essa forma de articulação do argumento do conhecimento técnico.

Outra perspectiva que pode ser adotada e que encontra uma maior aceitação é aquela que afirma que as questões constitucionais devem ser decididas por agentes imparciais e não interessados, alheios aos interesses políticos primários, o que justificaria a delegação de competência aos juízes. Afinal, prossegue esse tipo de argumentação, são esses os agentes que possuem todas as garantias institucionais, como a inamovibilidade e a vitaliciedade, para julgar questões relevantes com a maior isenção. Tal perspectiva é mais justificável em momentos de grande turbulência política, em que o Poder Judiciário assume a função de frear o afoitamento político.

Conter os impulsos em momentos de crise parece ser uma concepção persuasiva sobre papel das Cortes Constitucionais. Em situações normais da engrenagem política, contudo, não há, a priori, razões que indiquem que as soluções judiciais sejam sempre mais adequadas do

\footnotetext{
${ }^{72}$ VIEIRA, 2010, p. 489
} 
que as formuladas por agentes eleitos. Por mais bem instruído que seja o magistrado, questões que envolvem preferências não homogêneas na sociedade são antes políticas que jurídicas. A comparação entre os resultados do processo político e das decisões judiciais deveria ser realizada com base em dados empíricos para se definir quais matérias devem ser delegadas para as cortes. Uma conclusão, contudo, parece ser intuitiva: nem todos os problemas da nação devem ser decididos por juízes.

A falta de critério na delegação de competências para o Poder Judiciário enfraquece o argumento da competência funcional, já que não necessariamente vão ser canalizadas aos tribunais as questões que realmente são mais bem decididas por magistrados. A isenção e a imparcialidade não são componentes essenciais para a solução de determinadas questões, como por exemplo o método de pesagem de botijões de gás ${ }^{73}$. A experiência dos envolvidos na compra e venda do produto parece ser muito mais relevante do que o que diz a Constituição sobre o tema, o que leva a crer que outros órgãos que tenham contato direto com os consumidores seriam os mais indicados para desenvolver a política pública nesse âmbito. Não obstante, questões como essa desembocam hodiernamente nos tribunais, que acabam substituindo as razões políticas por juízos de razoabilidade e proporcionalidade formulados por magistrados, muitas vezes alheios às circunstâncias fáticas da causa.

É certo que Hart e Sacks, ao elaborarem o princípio ajuste institucional, não pareciam ter em mente essa transferência total das questões ao Poder Judiciário por meio dos princípios constitucionais. Conforme salientam Eskrdge Jr. e Frickey (1994, p. 2042), havia uma proposta de inclusão de um capítulo dedicado ao direito constitucional à obra The Legal Process que nunca saiu do papel.

Além disso, os constitucionalistas discípulos dessa corrente doutrinária foram críticos ferrenhos de várias decisões substantivas da Suprema Corte americana. Hebert Wechsler (1959), por exemplo, em artigo bastante influente na academia estadunidense, criticou a decisão em Brown que, em sua visão, seria arbitrária ao extrapolar o papel institucional da Corte de decidir os casos de acordo com princípios constitucionais neutros. Segundo o referido autor, a prática do judicial review, para ser considerada legítima, deveria ser guiada por princípios que poderiam ser aplicados indistintamente a outros casos. Ao interpretar o princípio da igualdade de maneira a beneficiar os litigantes negros, princípio que não poderia ser utilizados em outras circunstâncias, Wechsler concluiu ser problemática a decisão em

\footnotetext{
${ }^{73}$ Supremo Tribunal Federal, Ação Direta de Inconstitucionalidade nº. 855, Min. Rel. Octavio Gallotti, julgada em 06/03/08, acórdão publicado no DJ-e de 27/03/09.
} 
Brown $^{74}$. Independentemente de seus méritos, essas observações demonstram as dificuldades que devem ser enfrentadas por quem endosse o argumento da competência funcional. Quais temas os juízes devem ter competência para decidir e como contrangê-los a obedecer a essa diretriz são as angústias levantadas por essa justificativa.

\subsection{3 - O argumento procedimental}

A terceira forma de defesa do controle de constitucionalidade advoga que a atuação judicial é legítima desde que seja exercida em benefício do processo político democrático. Os defensores do argumento procedimental entendem ser função da jurisdição constitucional a manutenção de um governo democrático, impedindo o bloqueio dos canais de comunicação e participação política. O Poder Judiciário, nesse sentido, deve intervir na sociedade para possibilitar que todos os pontos de vista sejam expressos e levados a sério no processo político, o que impõe o dever de declarar a inconstitucionalidade de leis e práticas que visem a restringir ou excluir o acesso de certos grupos ao poder.

Para essa corrente de pensamento, ao invés de impor uma visão substantiva sobre os valores compartilhados pela sociedade, as principais cláusulas constitucionais teriam como escopo manter a higidez dos diversos procedimentos que intermedeiam a relação entre o cidadão e o Estado, seja judicial, administrativo ou político. Devido à pluralidade de visões de mundo, prossegue o argumento, seria um equívoco transferir para a Corte a responsabilidade de definir a identidade constitucional da nação. O papel dos tribunais seria o de permitir a formação da identidade constitucional da sociedade pelo processo democrático, desobstruindo os canais de mudança política. Os direitos diretamente relacionados à participação política, como a liberdade de expressão e de associação, são as principais ferramentas utilizadas pelos procedimentalistas para intervir e modificar a realidade social.

O procedimentalismo é uma concepção desconfiada quanto aos rumos que podem ser tomados pela política majoritária, caso não haja controle externo aos parlamentares. A perspectiva adotada é a de que, em certas situações, os detentores do poder podem influenciar diretamente nos resultados políticos a partir da edição de leis que privilegiem uma parcela da população em detrimento daqueles que não estão devidamente representados. Ao se detectar

\footnotetext{
${ }^{74}$ Wechsler (1959, p. 33-34) questionava se o princípios da não-segregação também se aplicaria às intuições que só aceitavam homens e à proibição então existente em alguns Estados de proibir o casamento intrarracial, respondendo de maneira negativa. Assim, a decisão em Brown seria equivocada, pois qualquer tentativa de enunciar um princípio geral neutro se mostrava falha. Para uma crítica de Wechsler, afirmando que a neutralidade requerida pela Constituição é de procedimentos e não de valores, cf. RICHARDS, 1977, p. 16-20.
} 
um mau funcionamento do processo político que impeça a efetiva participação de determinados grupos na formação do agir coletivo, o procedimentalismo defende a intervenção judicial para remediar essa falha. O jurista americano John Hart Ely, o precursor dessa linha de pensamento, expõe da seguinte forma as situações em que o controle de constitucionalidade se mostra necessário:

O método de interpretação constitucional por mim recomendado é similar com o que pode ser chamado de orientação "antitruste" em oposição à "regulatória" na área econômica - ao invés de ditar resultados substantivos, deve-se intervir somente quando o "mercado", em nosso caso o mercado político, está sistematicamente em mau funcionamento. [...] O mau funcionamento ocorre quando o processo não transpassa confiança, quando (1) os que estão dentro bloqueiam os canais de mudança política para garantir que eles irão continuar dentro e que aqueles que estão de fora continuarão de fora, ou (2) mesmo que a ninguém seja recusada a voz ou o voto, os representantes membros de uma efetiva maioria sistematicamente colocam certa minoria em desvantagem por hostilidade ou preconceito, recusando reconhecer uma comunidade de interesses, e assim denegando a essa minoria a mesma proteção ofertada aos demais grupos pelo sistema representativo.

Obviamente que nossos representantes eleitos serão as últimas pessoas em que devemos confiar para identificar quaisquer dessas situações. Juízes indicados, no entanto, são comparativamente alheios em nosso sistema governamental e somente obliquamente devem se preocupar em perder o cargo ${ }^{75}$.

Um ponto que merece atenção nesse trecho é que, para Hart Ely, revela-se essencial que haja efetiva representação política, o que significa dizer que a mera existência formal de eleições e de sufrágio universal não impede a intervenção judicial. Caso haja situações em que parcela da população se encontra marginalizada das escolhas sociais, ainda que não lhe seja denegado diretamente o direito de votar e ser votado, os juízes devem declarar nulas as leis que impeçam ou dificultem a igual influência dos diversos grupos e cidadãos. É nessa linha que Hart Ely considera legítima a decisão em Brown, já que as políticas públicas segregacionistas, a seu ver, impunham um estigma a um grupo minoritário da sociedade, tornando desigual o papel de brancos e negros no processo político.

O argumento procedimental, ao contrário dos demais argumentos já mencionados, tem a clara intenção de limitar a atuação dos tribunais na vida política. As leis somente devem ser declaradas inconstitucionais caso os direitos essenciais ao bom funcionamento de um processo democrático aberto e efetivo forem transgredidos. Ou seja, na visão de Ely as cortes devem ser ativistas na proteção da liberdade de expressão e sensíveis com relação aos efeitos

\footnotetext{
${ }^{75}$ Tradução livre de ELY, 1980, p. 102-103.
} 
deletérios dos preconceitos, mas não podem se imiscuir em questões que envolvem ponderação substantiva de valores.

A dificuldade dessa concepção reside na definição do que seja realmente relevante para o bom funcionamento do processo democrático. Como estabelecer os requisitos de um regime democrático saudável sem indicar quais os valores substantivos que devem ser observados é a questão posta por Ronald Dworkin (1985, p. 57-69). O conceito de democracia apresenta-se tão contestado ${ }^{76}$ quanto o conteúdo dos direitos fundamentais. Ao inserir em sua concepção uma necessidade de participação substantiva/material - e não meramente formal -, Hart Ely dá azo a uma série de questionamentos problemáticos.

$\mathrm{O}$ fato de as mulheres não poderem decidir os rumos de sua vida reprodutiva - e, consequentemente, de sua vida política ativa - não gera uma desigualdade de condições de participação a justificar a prática do aborto pelo viés procedimental? A desigualdade econômica não impõe um dever constitucional de transferência de renda para que todos tenham possibilidades materiais similares de influir nos rumos políticos do país? Para a efetiva participação política, não é necessário respeitar a dignidade da pessoa humana em todos os seus aspectos?

Até mesmo questões envolvendo a liberdade de expressão tornam-se casos difíceis. Para o bom funcionamento do processo democrático, o chamado "discurso ao ódio", em que os membros de certos grupos sociais são agredidos psicologicamente pela opinião de pessoas de fora, deve ser proibido, como no Brasil ${ }^{77}$, ou permitido, como nos Estados Unidos ${ }^{7879}$ ? Adotando-se a perspectiva procedimentalista, é mais importante permitir o amplo fluxo de ideias ou desincentivar o preconceito? A resposta a todas essas perguntas encerra uma discussão acerca dos direitos que devem ser garantidos em um regime democrático. Ao

\footnotetext{
${ }^{76}$ Waldron define democracia como um conceito essencialmente contestado, utilizando a linguagem de Walter Galie. De acordo com Waldron (2002, p. 149): "By contrast, a concept such as democracy evokes disagreement not only about marginal cases (say, Kuwait or Malaysia) but also about paradigm or core cases. For some, the United States is a paradigm or a core case of democracy: if it is not democracy nothing is. For others, the U.S. is not a good paradigm, not only because of things like low voter-turnout, lack of proportional representation, and compromises with various aristocratic ideals (like judicial review), but also because it lacks important features of social democracy - the empowerment in something more than merely formal terms, of the worst-off members of society. The disagreement between those who define democracy purely in terms of formal electoral arrangements and those who insist on a social element, is disagreement about the core or essence of democracy, and thus it seems to indicate that democracy might be described as essentially contested".

77 Supremo Tribunal Federal, Habeas Corpus nº 82.424, Min. Rel. Moreira Alves, julgado em 17/09/2003, publicado no DJ-e de 19/03/2004.

${ }^{78}$ R. A. V. v. City of Saint Paul, 505 U. S. 377 (1992)

${ }^{79}$ Sobre a diferença de perspectivas adotadas pelos tribunais dos Estados Unidos e da Alemanha com relação ao chamado hate speech, cf. ROSENFELD (2003).
} 
responder a essa questão filosófica mais ampla, o procedimentalismo muita vezes desemboca em um substancialismo, o que diminui sua força persuasiva ${ }^{80}$.

Não obstante a dificuldade teórica concernente à definição dos elementos caracterizadores de uma democracia em bom funcionamento, o argumento procedimental possui várias virtudes, como reconhecer a limitação dos juízes em pronunciar os valores da sociedade e enfatizar a importância do processo político majoritário. O sua adoção como teoria constitucional no Brasil, contudo, exigiria um esforço conceitual para adaptá-la a um texto fundamental que consagra uma série de princípios substantivos, como os princípios da moralidade e da economicidade, o que não significa que ela não tenha valia.

\subsection{4 - O argumento da proteção de direitos}

A quarta e última justificativa da expansão do Poder Judiciário remete à ideia de proteção de direitos fundamentais. $\mathrm{O}$ argumento segue o seguinte raciocínio: após as atrocidades cometidas pelos nazistas na Segunda Guerra Mundial, verificou-se a necessidade de se insular um núcleo mínimo de direitos da esfera política, a fim de se evitar que novos abusos fossem cometidos ${ }^{81}$. Estabeleceu-se, então, o controle das opções legislativas a partir da constitucionalização de um catálogo de direitos que serve de parâmetro de controle utilizado por cortes constitucionais criadas especialmente para conter eventuais transgressões à dignidade da pessoa humana por parte dos órgãos públicos ${ }^{82}$. Após algumas décadas de prática, em que se formou uma cultura de proteção a direitos, a experiência bem-sucedida

\footnotetext{
${ }^{80}$ Waldron (1999, p. 285) também acredita que o procedimentalismo é falho em sua tentativa de legitimar o judicial review na proteção limitada de direitos necessários para o bom funcionamento da democracia, pois tal argumentação acaba desaguando em um substancialismo. Em sua visão, "the right-based argument for democracy cannot be separated off from others rights in this way. Based as it is on respect for persons as moral agents and moral reasoners, the premises of that argument will certainly yield substantive conclusions about what people are entitled to so far as personal freedom is concerned and it may well yield conclusions about affirmative entitlements in the realm of social and economic well-being".

${ }^{81}$ Eduardo Cambi (2010, p. 31 e 35), árduo defensor do argumento da proteção de direitos, desenvolve o seu raciocínio da seguinte forma: "Com a derrota dos regimes totalitários (nazi-fascistas), verificou-se a necessidade de criarem catálogos de direitos e garantias fundamentais para a defesa do cidadão frente aos abusos que poderiam vir a ser cometidos pelo Estado ou por quaisquer detentores do poder em suas manifestações políticas, econômicas, intelectuais etc.", concluindo que "a derrota dos regimes totalitários também evidenciou a necessidade de criação de mecanismos efetivos de controle da Constituição, por intermédio do aperfeiçoamento [...] da jurisdição constitucional”.

${ }^{82}$ Martin Borowski (2003, p. 159-61), em estudo sobre a formação da Corte Constitucional alemã, corrobora esse entendimento ao afirmar: "A fundamental reason for the striking powers of the Federal Constitutional Court lies in the experience of the collapse of the Weimer Republic. The institutions of the Weimer Republic reflected what proved to be an undue optimism about things democratic. (...) There can be no doubt, however, that the fundamental motive lay in the experience with the lawless regime of the National Socialists. Against this backdrop, the safeguard provided by the legislator's substantive commitment to the basic rights is a natural step".
} 
europeia espalhou-se mundo afora ${ }^{83}$. A adoção de cartas constitucionais substantivas e tribunais constitucionais tornou-se padrão em países que atravessaram longos períodos de autoritarismo e restabeleceram o regime democrático nas últimas décadas.

A lógica do argumento da proteção de direitos é a de que nenhum ato governamental deve quedar-se imune ao crivo dos tribunais. A submissão dos outros poderes ao Judiciário por meio do controle de constitucionalidade baseado em um texto constitucional repleto de cláusulas substantivas foi a fórmula encontrada para monitorar a atividade governamental.

Como as cláusulas definidoras de direitos são expressas em termos amplos toda lei pode ter sua constitucionalidade questionada. Para os autores substantivistas, há enorme desconfiança com relação às decisões tomadas pela esfera política, o que desencadeia um processo quase automático de rediscussão nos tribunais das razões legislativas. Nesse modelo, as cortes constitucionais transformam-se praticamente em uma terceira instância política em que se afere a consistência das razões políticas adotadas pelos agentes públicos em leis e atos administrativos. É nesse sentido que Robert Alexy afirma ser argumentativa a representação que legitima os juízes a decidirem certas questões em nome do povo em contraste com a representação democrática dos parlamentares eleitos ${ }^{84}$.

Por ser o Poder Judiciário o órgão que lida diuturnamente com direitos, a função de fiscalizar se determinados atos governamentais são contrários aos direitos fundamentais parece estar bem alocada nos tribunais, o que é o ponto positivo do argumento da proteção de direitos. O que causa certa perplexidade é que em várias questões decididas pelo Supremo Tribunal Federal - como, por exemplo, a que declarou a constitucionalidade da lei que proibia a importação de pneus usados ${ }^{85}$ - a relação do tema com um direito fundamental concreto é tão distante que gera questionamentos acerca da capacidade institucional dos tribunais para decidir o tema.

\footnotetext{
${ }^{83}$ Alec Stone Sweet (2000, p. 31) assim descreve esta tendência mundial: "After the World War II, a 'newconstitutionalism' has emerged and widely diffused. Human rights have been codified and given a privileged place in the constitutional law; and quasi-judicial organs called constitutional courts have been charged with ensuring the normative superiority of the constitution. Such courts have been established in Austria (1945), Italy (1948), the Federal Republic of Germany (1949), France (1958), Portugal (1976), Spain (1978), Belgium (1985) and, after 1989, in the post-Communist Czech Republic, Hungary, Poland, Romania, Russia, Slovakia, the Baltics, and in several states of the former Yugoslavia".

${ }^{84}$ Robert Alexy afirma que o exercício do poder estatal pelo parlamento é legítimo porque seus membros são eleitos. Já os juízes dos tribunais constitucionais também exerceriam o poder estatal legitimamente por meio de uma representação argumentativa. Para que essa representação seja realmente autêntica, Alexy (2008, p. 165) estabelece duas condições: "(1) a existência de argumentos válidos ou corretos e (2) a existência de pessoas racionais que são capazes e dispostas a aceitar argumentos válidos ou corretos porque eles são válidos e corretos. [...] Jurisdição constitucional somente então pode ser exitosa quando esses argumentos, que são alegados pelo tribunal constitucional, são válidos e quando membros, suficientemente muitos, da comunidade, são capazes e dispostos a fazer uso de suas possibilidades racionais".

${ }^{85}$ Supremo Tribunal Federal, Arguição de Descumprimento de Preceito Fundamental nº 101, Rel. Min. Cármen Lúcia, julgada em 24/06/2009, acórdão publicado no DJ-e de 01/06/2012.
} 
Ademais, a interpretação das cláusulas constitucionais atinge patamares tão abstratos que a atividade jurisdicional acaba por assemelhar-se à legislativa. Ao decidir, por exemplo, que o aborto é uma prática constitucionalmente permitida pela cláusula do devido processo legal, como o fez a Suprema Corte americana ${ }^{86}$, a conclusão é tão afastada dos termos constitucionais que dificilmente um leigo consegue entender como os juízes chegaram a tal conclusão. A ausência de limites à criação judicial acaba por enfraquecer esse argumento.

Apesar dessas fragilidades, dentre as diversas perspectivas apresentadas, o argumento da proteção de direitos tem sido amplamente aceito como principal justificativa para a jurisdição constitucional. Constitucionalistas brasileiros consagrados, como Inocêncio Mártires Coelho (2007, p. 116), enfatizam que o que distingue a interpretação constitucional, tal como ela é atualmente praticada, reside na tentativa dos juízes de conferir efetividade aos princípios decorrentes da constitucionalização dos direitos fundamentais. Na visão do referido autor, o problema hermenêutico da jurisdição constitucional consiste na tradução em realidade das promessas contidas nas cláusulas constitucionais que enunciam direitos. Em sentido semelhante, Walber de Moura Agra pontua:

Os direitos fundamentais são o principal elemento para a legitimação da atuação da jurisdição constitucional, tornando-a apta para enfrentar as demandas da sociedade. Quando o processo de expansão da atuação da jurisdição constitucional se ampara sobre os seus fundamentos, até mesmo as decisões que incidem em controversas searas políticas encontram respaldo na sociedade, desempenhando o órgão que exerce a jurisdição constitucional um papel de guardião dos direitos agasalhados pela Constituição ${ }^{87}$.

A ideia de que o papel precípuo do Supremo Tribunal Federal é o de dar efetividade aos direitos fundamentais difundiu-se de tal maneira que se tornou comum encontrarmos na mídia artigos, como o publicado no editorial da Folha de S. Paulo do dia 16/05/2009, afirmando que "[o] controle da constitucionalidade das leis é decisivo para o funcionamento do Estado de Direito, na medida em que assegura direitos e garantias fundamentais para os cidadãos e a segurança jurídica nas relações políticas, econômicas e sociais".

É no contexto do argumento da proteção de direitos que emerge a doutrina do Neoconstitucionalismo ${ }^{88}$. O que torna peculiar essa doutrina é a ampla definição dada aos direitos fundamentais e aos princípios, o que transforma toda questão jurídica em questão

\footnotetext{
${ }^{86}$ Roe v. Wade, 410 U.S. 113 (1973).

87 AGRA, 2008, p. 490.

88 Daniel Sarmento (2009, p. 128) é conclusivo ao afirmar que "não há dúvida de que a [posição] mais identificada ao Neoconstitucionalismo é a substancialista".
} 
constitucional, exigindo a ponderação entre vários direitos supostamente em confronto. A explicitação dessas teses neoconstitucionais é o tema do próximo capítulo. 


\section{Capítulo 2 - As teses do Neoconstitucionalismo}

\section{1 - Efeitos do Neoconstitucionalismo: a constitucionalização do Direito}

Até aqui restou demonstrado que o Neoconstitucionalismo está inserido no contexto da utilização progressista da jurisdição constitucional a partir de uma leitura abstrata dos princípios que possibilitam realizar mudanças estruturais na sociedade, mesmo que não haja engajamento político para tanto. Ao invés de preservar os compromissos constitucionais estabelecidos (visão retrospectiva), à Corte é designada a função de criticar moralmente a sociedade, ensejando decisões proféticas sobre o conteúdo do texto constitucional (visão prospectiva). Além disso mostrou-se que, atualmente, a justificativa para esse exercício de poder por parte de tribunais é a proteção de direitos fundamentais. A forma como todos esses elementos são encadeados pelos autores que se dizem neoconstitucionalistas, no entanto, merece análise mais detida em razão da extensão dos efeitos de suas propostas. É o que se pretende fazer neste tópico.

O Neoconstitucionalismo se apresenta como uma teoria jurídica focada em uma visão progressista do papel dos juízes, justificada pela adoção de uma concepção axiológica de Constituição que exige o manejo de técnicas interpretativas especiais aptas a lidar primordialmente com normas-princípios, notadamente o juízo de ponderação. A adoção dessa perspectiva, contudo, encerra uma série de outros desdobramentos relacionados ao chamado fenômeno da constitucionalização do direito que merecem uma atenção especial para os fins da presente Tese. Tal fenômeno nada mais é do que a caracterização de todos os casos jurídicos como casos constitucionais em virtude do efeito irradiador do texto fundamental defendido pelos neoconstitucionalistas - o que faz com que todos os processos se transformem em potenciais Brown v. Board of Education. Dito de outra forma, o Neoconstitucionalismo parece assumir o modelo Brown como o padrão judicial a ser adotado pelos juízes até mesmo nos casos judiciais mais simples.

Obviamente que isso tem sérias implicações tanto para os juízes que decidirão os casos quanto para os jurisdicionados que serão afetados pelo modo como os casos serão decididos. O pensamento neoconstitucionalista está bem exemplificado nas obras de Eduardo Ribeiro Moreira, Luís Roberto Barroso, Antônio Cavalcanti Maia e Daniel Sarmento, cujas teses serão descritas a seguir. 


\section{2 - Eduardo Ribeiro Moreira e a "Invasão da Constituição"}

Em 2008, veio a lume a obra "Neoconstitucionalismo: A Invasão da Constituição", de Eduardo Ribeiro Moreira (p. 15-16), cujos propósitos são de "apresentar de forma coesa e objetiva a estruturação do Neoconstitucionalismo, defendendo-o como uma nova teoria do direito", bem como "desenvolver o Neoconstitucionalismo de modo a demonstrar sua aplicabilidade ao contexto brasileiro". Trata-se de um verdadeiro manifesto a favor do Neoconstitucionalismo. A obra é dividida em 13 capítulos, sendo que os 4 primeiros tentam contextualizar essa corrente doutrinária dentro do contexto histórico-teórico, enquanto os capítulos de 5 a 10 visam a estruturar seus elementos práticos. Os capítulos seguintes são voltados para aplicações concretas desses elementos nas áreas do direito internacional, orçamentário, tributário e penal. O que importa para os presentes fins são os capítulos centrais da obra do autor.

Ao definir os elementos do Neoconstitucionalismo, Eduardo Moreira (2008, p. 73-80) afirma que os pressupostos do constitucionalismo tradicional, como a rigidez constitucional, o controle de constitucionalidade e a proteção dos direitos fundamentais devem ser compreendidos no novo paradigma a partir de uma atualização de seus significados. À rigidez constitucional é acoplada a ideia de vedação do retrocesso, que proíbe alterações constitucionais que remetam a um estágio antecedente e indesejável. Essa inovação requer que os juízes, ao depararem com uma legislação novel, não somente averiguem se há violações ao texto constitucional, mas também sopesem as consequências do ato legislativo com a situação anterior para decidir se há uma piora na situação dos cidadãos, o que a tornaria inconstitucional. Já o controle de constitucionalidade passa a ser subordinado à ideia de proteção dos direitos fundamentais. Como consequência, a concretização dos direitos fundamentais, que no modelo anterior era função do parlamento, passa a ser função da jurisdição constitucional. Até aqui nenhuma novidade.

Com relação ao Neoconstitucionalismo propriamente dito, Eduardo Ribeiro Moreira elenca 4 (quatro) elementos que o distinguem: a sobreinterpretação da Constituição, a ponderação dos direitos fundamentais, a eficácia direta dos direitos fundamentais nas relações privadas e a possibilidade de controle judicial das políticas públicas.

Com o prefixo "sobre" adicionado à expressão "interpretação da Constituição", Moreira (2008, p. 81-91) procura dar ênfase à força normativa do texto constitucional no processo de hermenêutica jurídica. Em sua visão, a constitucionalização do direito é produto 
da sobreinterpretação, pois toda decisão judicial é uma interpretação constitucional de alguma forma. Eis o trecho em que o jurista esclarece este seu entendimento:

A sobreinterpretação tem um significado ainda mais abrangente. Toda decisão legislativa ou judicial está pré-regulada por uma norma constitucional. A produção legislativa, como todos sabem, é aberta ao controle de constitucionalidade, em que a interpretação constitucional se manifesta. Já o fenômeno que ocorre com a interpretação nas fases de aplicação da decisão judicial revela que toda interpretação jurídica - direta ou indiretamente - é interpretação constitucional, de forma que ela não deixa espaços vazios.

A vinculação do texto constitucional, como sobreinterpretação, dá-se de forma direta quando a decisão judicial se baseia em um princípio ou qualquer norma constitucional. Aí aparece a Constituição concretizada. A sobreinterpretação é indireta em dois momentos. No primeiro, por um juízo negativo sempre presente, que significa que o dispositivo legal que fundamenta a decisão passou por um juízo negativo com sucesso; em confronto com as normas constitucionais, o dispositivo legal, base para a decisão, sobreviveu - não é com a Constituição incompatível - juízo antecedente ao próprio exame do mérito concreto. No segundo momento é indireta a interpretação constitucional, por um juízo finalístico, já que toda decisão deve cumprir a Constituição e se orientar pelos objetivos nela destacados. Em tese, toda decisão deveria orientar-se por atender a um fim constitucional. Desses três exercícios de hermenêutica - direto, indireto negativo e indireto positivo - é que se extrai a inescapável conclusão de que toda interpretação jurídica é antes de tudo uma interpretação constitucional ${ }^{\text {. }}$.

Exige-se, assim, que o intérprete faça uma interpretação constitucional, com força transformadora, em todos os casos apresentados ao Judiciário em detrimento da previsibilidade e da segurança jurídica. Isso se torna mais evidente quando o tema de interpretação conforme a Constituição é tratado pelo autor. Segundo Moreira (2008, p. 88-89), há três sentidos possíveis para essa expressão. O primeiro diz respeito à própria função judicante, pois para o Neoconstitucionalismo toda interpretação é constitucional, conforme visto acima. O segundo refere-se à decisão judicial que indica qual dentre as várias interpretações possíveis de uma norma é constitucionalmente adequada. Até então não há novidade.

É com a formulação do terceiro sentido dado à interpretação conforme a Constituição que o autor confere aos tribunais uma maior liberdade de conformação. De acordo com Moreira, o juiz, diante do caso concreto, pode excepcionalmente afastar os efeitos de uma regra em razão de uma interpretação constitucional principiológica, fenômeno por ele

\footnotetext{
${ }^{1}$ MOREIRA, 2009, p. 82.
} 
designado como derrotabilidade da norma ${ }^{2}$, ainda que essa norma não padeça de vício de inconstitucionalidade. Trata-se de um juízo de razoabilidade dos efeitos de uma norma que pode levar à sua derrota. Isso se deve à posição conferida aos princípios pelo autor, que "passaram de papel auxiliar ao de proeminência" na hermenêutica jurídica. Esse ponto remete ao segundo elemento característico do Neoconstitucionalismo: a ponderação de direitos fundamentais.

De acordo com o autor, em virtude de sua incidência projetiva e aberta à interpretação, os princípios possuem muito mais relevância do que as regras. A abstração dos princípios é considerada uma vantagem dessa espécie normativa, pois permitiria a sua concreção por meio de uma interpretação judicial criativa. No caso brasileiro, as normas programáticas também são consideradas princípios para o jurista, o que torna o papel do juiz ainda mais complexo. Tendo em vista a abertura e a quantidade de princípios, muitas vezes contraditórios, o intérprete necessariamente deverá realizar exercício de ponderação, decidindo, assim, qual valor deve prevalecer no caso concreto. Note-se, desde já, que em razão de Moreira vislumbrar ser possível a ponderação de políticas públicas (normas programáticas) com princípios, sua teoria se distancia do pensamento de Dworkin $^{3}$ e se aproxima de um pragmatismo jurídico em que leis podem ser afastadas com base em análises consequencialistas, tema que adiante será tratado com mais profundidade. No momento, basta enfatizar que o Neoconstitucionalismo proposto por Moreira possibilita, por meio da ponderação, analisar o mérito legislativo. O próprio autor deixa isso claro na seguinte passagem:

A proporcionalidade é parâmetro para o juiz adentrar em um mérito da razão da lei, para resolver o confronto entre princípios. O juiz, na verdade, pela proporcionalidade, decide aquilo que o legislador não ponderou, não criou regra que considerasse os interesses postos em jogo ${ }^{4}$.

\footnotetext{
${ }^{2}$ Nesse sentido, Eduardo Moreira (2008, p. 94-95) explica que: "A regra sofrerá efeito excepcional e não incidirá, casuisticamente, pela sua derrotabilidade factual - após a inferência do caso concreto, mas nunca abstrata. A composição do sistema constitucional e a do modelo de princípios e regras ficam mais aperfeiçoadas, permitindo que estas sofram a derrotabilidade no plano pragmático. Não se trata de ponderar regras - efeito exclusivo dos princípios -, mas de aceitar, via o terceiro sentido da interpretação conforme a Constituição, a sua derrotabilidade".

${ }^{3}$ A teoria de Ronald Dworkin baseia-se em uma noção deontológica de princípios que funcionariam como trunfos contra as decisões majoritárias. Os princípios, diretamente ligados a direitos, seriam utilizados, assim, de forma não utilitarista e independentemente da análise das consequências. As políticas públicas, por outro lado, são objetivos da comunidade, como o alcance de índices econômicos ou uma reforma política, que podem estar em confronto com os direitos fundamentais. No pensamento de Dworkin, essa diferenciação é importante por traçar a linha divisória entre uma atividade jurisdicional legítima e uma ilegítima: enquanto os juízes julgam de acordo com argumentos de princípios, e não de política, a atividade é legítima. Sobre o assunto, cf. GUEST, 1991, p. 60-64.

${ }^{4}$ MOREIRA, 2008, p. 106.
} 
Eduardo Moreira (2008, p. 111-127) também defende a invasão dos direitos fundamentais nas relações entre particulares com $\mathrm{o}$ fito de moralizar as relações intersubjetivas por meio de interpretação judicial. O autor critica o Código Civil de 2002, que teria poucas cláusulas abertas, o que dificultaria a concretização dos direitos fundamentais, pois, seu ver, a sua efetividade decorreria primordialmente das decisões judiciais ${ }^{5}$. Para remediar essa situação, Moreira defende a aplicação plena e direta das cláusulas constitucionais às relações entre particulares. A possibilidade de o juiz afastar uma norma no caso concreto com base nos efeitos advindos de sua aplicação, sem que haja qualquer vício de inconstitucionalidade, volta à cena nessa seara. Para o autor, "[a]s situações provocadas, muitas vezes se baseiam em leis constitucionais, mas é no ato privado [...] que se contraria o direito fundamental, sem que a lei correspondente seja inconstitucional"6.

Em suma, o Neoconstitucionalismo de Eduardo Moreira defende uma presença invasora da Constituição em todas as causas, o que gera uma necessidade de se avaliar em cada caso o mérito das consequências da aplicação das leis, o que por si só pode levar a sua anulação.

O último elemento do Neoconstitucionalismo descrito por Eduardo Moreira (2008, p. 129-147) é a possibilidade de controle das políticas públicas. Ao elaborar esse ponto, o autor condensa várias das ideias acima descritas. Segundo Moreira, a sobreinterpretação constitucional sugere que todo ato estatal emana de um preceito constitucional, o que desencadeia o fenômeno da constitucionalização do direito. Por outro lado, as políticas públicas previstas na Constituição têm natureza de princípio, o que significa que elas podem ser ponderadas com outras políticas públicas e com os direitos fundamentais. Como consequência dessas teses, ele conclui que cumpre ao Poder Judiciário adentrar no mérito das escolhas públicas para exigir que determinada política adotada pelo administrador seja modificada a fim de se adequar ao espírito constitucional. Nesse sentido, confira:

O critério de pretensão de correção age, concretamente, exigindo-se do administrador que adapte as opções públicas à vontade constitucional, traduzida por princípios e objetivos que são formados pelo direito e presentes na Constituição. A conclusão a que se chega, ao adotar essa percepção, é de que tanto as omissões como as ações do poder público, na execução das políticas públicas, são controláveis pelo Poder Judiciário ${ }^{7}$.

\footnotetext{
${ }^{5}$ O próprio autor (2008, p. 119) deixa esse pensamento claro ao afirmar que "em suma, o Neoconstitucionalismo aposta no Poder Judiciário e no Ministério Público com mais poderes e meios de atuação”.

${ }^{6}$ MOREIRA, 2008, p. 117.

${ }^{7}$ MOREIRA, 2008, p. 137.
} 
Com esse passo, Eduardo Moreira Ribeiro encerra o processo de elaboração de um arsenal interpretativo que possibilita aos juízes invalidarem atos dos demais poderes em razão de seu mérito, ainda que não contenham vícios de inconstitucionalidade.

\section{3 - Luís Roberto Barroso e o "Triunfo Tardio do Direito Constitucional"}

Luís Roberto Barroso, talvez o autor adepto do Neoconstitucionalismo que exerça maior influência na academia brasileira, publicou, em 2007, o artigo “Neoconstitucionalismo e constitucionalização do direito (o triunfo tardio do direito constitucional no Brasil)", no qual reuniu as principais teses que, a seu ver, compõem a essência dessa corrente doutrinária. Esse artigo embasará a presente análise.

O jurista inicia seu texto procurando reconstruir as transformações ocorridas no direito constitucional nas últimas décadas, levando-se em conta três marcos fundamentais. O marco histórico, considerado como constitucionalismo do pós-guerra, baseado principalmente nas experiências da Alemanha e da Itália, que no Brasil tomou corpo a partir da Constituição Federal de 1988. O marco filosófico, que ele considera ser o pós-positivismo, consubstanciado na confluência entre as doutrinas do positivismo e do jusnaturalismo, o que teria desencadeado um conjunto amplo e ainda inacabado de reflexões acerca da função e da interpretação do Direito. Por fim, o marco filosófico, que se refere a três transformações que supostamente teriam subvertido o conhecimento relativo à aplicação do direito constitucional: i) o reconhecimento de força normativa à Constituição; ii) a expansão da jurisdição constitucional; e iii) o desenvolvimento de uma nova dogmática da interpretação constitucional $^{8}$.

Por força normativa da Constituição, Barroso entende ser o reconhecimento do caráter vinculativo e obrigatório de suas disposições. As normas constitucionais, assim como quaisquer outras normas jurídicas, passaram a ser dotadas de imperatividade, tendo aplicabilidade direta e imediata. Já a expansão da jurisdição constitucional seria o fenômeno iniciado na década de 1950, com a criação do modelo alemão de controle concentrado que se

\footnotetext{
${ }^{8}$ Barroso (2007, p. 216) assim resume sua própria concepção: “Em suma: o Neoconstitucionalismo ou novo direito constitucional, na acepção aqui desenvolvida, identifica um conjunto de transformações ocorridas no Estado e no direito constitucional, em meio às quais podem ser assinalados, (i) como marco histórico, a formação do Estado constitucional de direito, cuja consolidação se deu ao longo das décadas finais do século $X X$; (ii) como marco filosófico, o pós-positivismo, com a centralidade dos direitos fundamentais e a reaproximação entre Direito e ética; e (iii) como marco teórico, o conjunto de mudanças que incluem a força normativa da Constituição, a expansão da jurisdição constitucional e o desenvolvimento de uma nova dogmática da interpretação constitucional que resultou um processo extenso e profundo de constitucionalização do direito".
} 
espalhou por toda a Europa continental e parte da América Latina. No Brasil, que já adota o controle de constitucionalidade difuso desde 1891, a expansão da jurisdição constitucional seria decorrente da ampliação dos legitimados para a propositura de ações diretas e da criação de novos mecanismos de controle concentrado ocorridas com a promulgação da Carta de 1988.

É no momento em que se chega à nova dogmática constitucional que o texto de Barroso torna-se mais interessante para os presentes fins. Segundo ele, como consequência do reconhecimento da força normativa da Constituição, os operadores do direito perceberam que as categorias tradicionais de interpretação jurídica não eram inteiramente ajustadas para a solução de um conjunto de questões ligadas à concretização do texto constitucional. Daí iniciou-se um intenso processo de elaboração de um arsenal teórico adequado para a nova situação, transmudando-se as funções tradicionais da norma e do juiz. A interpretação, antes ato de conhecimento, adquiriu novo status, já que a norma, no novo paradigma, não mais oferece solução aos problemas jurídicos. O juiz torna-se coautor do processo de criação do Direito, "completando o trabalho do legislador, ao fazer valorações de sentido para as cláusulas abertas e ao realizar escolhas entre soluções possíveis".

Ainda segundo Barroso, a transformação do papel do juiz deve-se principalmente às categorias com que ele trabalha na nova interpretação constitucional, nas quais se incluem as cláusulas gerais, os princípios, as colisões de normas constitucionais, a ponderação e a argumentação. A menor densidade jurídica das normas que em geral são utilizadas pelos neoconstitucionalistas faz com que o intérprete tenha que integrar o comando normativo com a sua própria avaliação. Além disso, "a existência de colisões de normas constitucionais, tanto as de princípios de direitos fundamentais, passou a ser percebida como um fenômeno natural", pois as constituições modernas consagram bens jurídicos que se contrapõem, de maneira que, para a solução dos conflitos, é necessário realizar um juízo de ponderação, cujo "conceito-chave na matéria é o princípio instrumental da razoabilidade" ${ }^{10}$. Por fim, para assegurar a legitimidade e a racionalidade de sua conclusão, o magistrado deve saber argumentar o seu ponto de vista, reconduzindo sua decisão ao sistema jurídico, utilizando-se um fundamento que possa ser generalizado aos casos equiparáveis e levar em consideração as consequências práticas de sua decisão.

Quando o autor realiza o trabalho de sintetização dos fenômenos abstratos acima referidos pode-se ter a exata dimensão das consequências do Neoconstitucionalismo na versão

\footnotetext{
9 BARROSO, 2007, p. 214.

${ }^{10}$ BARROSO, 2007, p. 215.
} 
de Barroso. O fenômeno da constitucionalização do Direito por ele narrado nos oferece uma boa oportunidade para conferir a extensão de sua proposta:

A ideia de constitucionalização do Direito [...] está associada a um efeito expansivo das normas constitucionais, cujo conteúdo material e axiológico se irradia, com força normativa, por todo o sistema jurídico. Os valores, os fins públicos e os comportamentos contemplados nos princípios e regras da Constituição passam a condicionar a validade e o sentido de todas as normas do direito infraconstitucional. Como intuitivo, a constitucionalização repercute sobre a atuação dos três poderes, inclusive e notadamente nas suas relações com os particulares. Porém, mais original ainda: repercute, também, nas relações entre particulares ${ }^{11}$.

Barroso entende que a Constituição tem o condão de influenciar as condutas dos próprios cidadãos em seu cotidiano, estabelecendo limites em domínios como a liberdade de contratar e o do uso da propriedade privada, subordinando todo o sistema jurídico às normas constitucionais, que possuem aplicabilidade imediata e direta ${ }^{12}$. Essa expansão do texto constitucional também impõe deveres de atuação à Administração Pública e fornece fundamento de validade para a prática de atos de aplicação direta e imediata da Constituição, independentemente de haver lei intermediando a ação ${ }^{13}$, pois " a Constituição passa a ser não apenas um sistema em si - com a sua ordem, unidade e harmonia - mas também um modo de olhar e interpretar os outros ramos do Direito", de maneira que "toda a ordem jurídica deve ser lida e aprendida sob a lente da Constituição". O texto constitucional "funciona, assim, não apenas como parâmetro de validade para a ordem infraconstitucional, mas também como um vetor de interpretação de todas as normas do sistema" ${ }^{14}$.

O último aspecto ressaltado pelo autor diz respeito à judicialização das relações sociais. Segundo Barroso, "uma das mais instigantes novidades no Brasil dos últimos anos foi a virtuosa ascensão institucional do Poder Judiciário" ${ }^{15}$. Os juízes, antes agentes técnicos e especializados, passaram a desempenhar um papel político, dividindo o protagonismo com o legislador e o administrador. Em razão da constitucionalização do Direito, do aumento da

\footnotetext{
11 BARROSO, 2007, p. 217-218.

12 Os critérios estabelecidos por Barroso (2007, p. 234) para restringir a autonomia do indivíduo no caso concreto em decorrência da aplicação horizontal dos direitos fundamentais são: “a) a igualdade ou desigualdade material entre as partes (...);b) a manifesta injustiça ou falta de razoabilidade do critério (...); c) preferência para valores existenciais sobre os patrimoniais; d) risco para a dignidade da pessoa humana".

${ }^{13}$ Nas palavras do autor (2007, p. 238): “O administrador pode e deve atuar tendo por fundamento direto a Constituição e independentemente, em muitos casos, de qualquer manifestação do legislador ordinário. $\underline{\boldsymbol{O}}$ princípio da legalidade transmuda-se, assim, em princípio da constitucionalidade, ou, talvez mais propriamente, em princípio da juridicidade, compreendendo sua subordinacão à Constituicão e à lei, nessa ordem". (grifo nosso).

${ }^{14}$ BARROSO, 2007, p. 227.

15 BARROSO, 2007, p. 243.
} 
demanda por Justiça após a redemocratização do Brasil e da ascensão do Judiciário, ocorreu expressiva judicialização de questões políticas e sociais, que passaram a ter nos tribunais os seus principais fóruns de debates. Decisões dos tribunais referentes a políticas públicas, relações entre poderes, direitos fundamentais e questões do dia a dia ${ }^{16}$ são vistas com bastante otimismo pelo autor, que entende que o Poder Judiciário possui melhores condições ${ }^{17}$ e maior legitimidade ${ }^{18}$ para decidi-las.

Em suma, o Neoconstitucionalismo proposto Barroso defende a tese de que a Constituição, em virtude de sua supremacia e força normativa, deve servir de norte para todos os atos da vida coletiva. Tanto os juízes quanto os cidadãos e os administradores, ao aplicarem determinada norma jurídica, devem, antes, averiguar se os fins objetivados por ela se coadunam com os valores constitucionalmente protegidos. Além disso, tendo em vista que a matéria-prima do Neoconstitucionalismo são as normas de baixa densidade normativa, como os princípios e as cláusulas gerais, as colisões de normas constitucionais tornam-se cada vez mais frequentes, exigindo do intérprete a realização de um juízo acerca da proporcionalidade e da razoabilidade das normas antes de aplicá-las ao caso concreto.

Todos esses aspectos, recebidos com otimismo por Barroso, levam inexoravelmente a uma impregnação judicial, nos termos de Miguel Carbonell ${ }^{19}$, e salientam o aspecto de criação do Direito por meio da interpretação constitucional. Esse último fato é assumido sem constrangimento pelo autor, que crê na possibilidade de se realizar uma verdadeira revolução humanista por meio de decisões judiciais proferidas por magistrados progressistas.

\section{4 - Antônio Cavalcanti Maia e “As Transformações dos Sistemas Jurídicos Contemporâneos"}

Antônio Cavalcanti Maia, Professor de Filosofia do Direito da Universidade Estadual do Rio de Janeiro, vem publicando, desde 2007, em diversas revistas e livros jurídicos, um artigo intitulado de "As Transformações dos Sistemas Jurídicos Contemporâneos:

\footnotetext{
${ }^{16} \mathrm{O}$ autor cita como exemplos de casos decididos pelo Pretório Excelso que influenciam no cotidiano dos cidadãos questionamentos quanto a legalidade de cobrança de assinaturas telefônicas, a majoração do valor das passagens de ônibus ou a fixação do valor máximo de reajuste de mensalidade de planos de saúde.

17 Assim explica Barroso (2007, p. 244): "Sem embargo de desempenhar um papel político, o Judiciário tem características diversas das dos outros Poderes. É que seus membros não são investidos por critérios eletivos nem por processos majoritários. E é bom que seja assim. (...) Idealmente preservado das paixões políticas, ao juiz cabe decidir com imparcialidade, baseado na Constituição e nas leis".

18 Neste sentido, afirma o autor (2007, p. 248): "O déficit democrático do Judiciário, decorrente da dificuldade contramajoritária, não é necessariamente maior que o do Legislativo, cuja composição pode estar afetada por difunções diversas".

19 CARBONELL, 2003a, p. 12.
} 
Apontamentos do Neoconstitucionalismo", em que procura sintetizar os elementos que configurariam um novo quadro de referência para o momento neoconstitucional. Em função de sua difusão no ambiente acadêmico, também serão descritas as principais ideias desse artigo para análise de suas consequências.

Antonio Cavalcanti Maia inicia o seu texto afirmando que a incorporação de conteúdos substantivos no ápice da estrutura legal, com a materialização da Lei Maior, implicou uma nova forma de pensar as relações entre direito e moral: os princípios constitucionais teriam aberto uma via de penetração moral no direito positivo, o que exige uma reformulação teórica para descrever, compreender e melhor operacionalizar a aplicação efetiva das normas constitucionais.

$\mathrm{O}$ autor explica que essas transformações impuseram a necessidade de elaboração de uma nova dogmática, chamada por ele de pós-positivista, cuja principal característica reside no reconhecimento da centralidade dos princípios na compreensão dos sistemas jurídicos. Maia, então, assevera que "as mais genuínas normas constitucionais carecem com frequência de determinação fática ou determinação jurídica, quando não de ambas" ${ }^{20}$, o que acarreta uma série de consequências filosóficas por ele veneradas. A utilização de vários standards nos textos constitucionais, na forma de princípios, valores e direitos fundamentais, realizariam uma plasmação jurídica de conteúdos de natureza moral.

Tais modelos normativos romperiam com o positivismo jurídico em razão da impossibilidade de aplicá-los por meio da ponderação e por demandar a utilização de elementos políticos e morais nas razões dadas aos casos difíceis que seriam inteligíveis pelas teorias tradicionais. De acordo com o autor, essa nova configuração lastreada em princípios, além propiciar uma descrição mais fidedigna de nosso sistema jurídico, mostra-se "mais adequada às possibilidades de uma utilização progressista, isto é, democrático-igualitária, marcada por um viés redistributivo" ${ }^{21}$.

Amparado em Sanchís, Antonio Cavalcanti Maia afirma que o jurista atualmente lida com mais princípios que regras; mais ponderação que subsunção; presença da Constituição em todas as áreas jurídicas e em todos os conflitos minimamente relevantes; e onipresença judicial em lugar da autonomia do legislador. Essa nova configuração teórica teria gerado o fenômeno da constitucionalização o direito assim descrito pelo autor:

\footnotetext{
${ }^{20}$ MAIA, 2008, p. 213.

${ }^{21}$ MAIA, 2008, p. 214, grifo nosso.
} 
Com as Constituições democráticas do século XX, outro aspecto assume lugar cimeiro: trata-se da circunstância de as Constituições serem erigidas à condição de norma diretiva fundamental, que se dirige aos poderes públicos e condiciona os particulares de tal maneira que assegura a realização dos valores constitucionais ${ }^{22}$.

O jurista também destaca que o Neoconstitucionalismo impõe uma rearticulação da tradicional forma de separação de poderes com o crescente protagonismo do Poder Judiciário, em especial das Cortes Constitucionais. Ao mesmo tempo em que o caráter principiológico acarreta uma invasão do texto constitucional em todos os temas relevantes, as decisões judiciais passam a depender de argumentos complexos que se utilizam da racionalidade teleológica A ponderação passa a ser o instrumento essencial para o neoconstitucionalista resolver os conflitos entre direitos fundamentais.

Conclui o autor que os direitos fundamentais e a sua capacidade de irradiação transformam-se em um mecanismo de garantia de efetivação dos impulsos emancipatórios, o que se dá por meio de uma hermenêutica progressista, tornando o Neoconstitucionalismo uma apreciação mais otimista acerca do papel do Direito nas sociedades contemporâneas.

\section{5 - Daniel Sarmento e a "Ubiquidade Constitucional"}

Daniel Sarmento elabora, em dois textos - "Ubiquidade Constitucional: Os Dois Lados da Moeda", publicado em 2007, e "O Neoconstitucionalismo no Brasil: Riscos e Possibilidades", de 2009 - uma compreensão conflituosa do Neoconstitucionalismo e do fenômeno da constitucionalização do direito. Se, por um lado, o autor endossa as teses decorrentes desse "novo paradigma tanto na teoria jurídica quanto na prática dos tribunais", por outro, reconhecendo os efeitos problemáticos dessa adoção, procura ajustar a sua teoria para evitar o que ele chama de "carnavalização da Constituição" ou "oba-oba constitucional". Ocorre que nessa tentativa de adaptação Daniel Sarmento acaba adotando pontos de vista aparentemente contraditórios ou de difícil conciliação. Tendo em vista os propósitos da presente Tese, torna-se relevante identificar, expor e analisar essas tensões na obra deste autor que se considera um neoconstitucionalista com reservas ${ }^{23}$.

\footnotetext{
22 MAIA, 2008, p. 220.

${ }^{23}$ Em virtude dessas ressalvas quanto às aplicações que considera radicais, Sarmento (2009, p. 146) afirma que somente endossaria uma teoria neoconstitucional se ela contivesse as seguintes cacterísticas: a) ao mesmo tempo em que abre espaço para os princípios e para a ponderação, não descarta a importância das regras e da subsunção; b) ao mesmo tempo em que reconhece e valoriza a irradiação dos valores constitucionais pelo ordenamento, bem como a atuação firme e construtiva do Judiciário na proteção e na promoção dos direitos fundamentais, não despreza o papel de protagonista das instâncias democráticas na definição do Direito; e c)
} 
O ponto de partida do pensamento de Daniel Sarmento é a percepção da emergência de uma nova forma de conceber o Direito, notadamente o direito constitucional, a partir da redemocratização do país. Em ambos os textos, o jurista afirma que até a promulgação da Constituição de 1988 havia uma cultura jurídica que não considerava as normas constitucionais como autênticas normas jurídicas. Assim, apesar de haver direitos consagrados nos textos constitucionais anteriores, a sua efetividade dependia da boa vontade dos governantes.

$\mathrm{Na}$ fase inaugurada com a nova Carta, "a doutrina brasileira [passou a] enfatizar o caráter normativo e a importância dos princípios constitucionais, e a estudar as peculiaridades de sua aplicação" ${ }^{\text {24 }}$, ideias que logo encontraram eco nas práticas dos tribunais, principalmente do Supremo Tribunal Federal. Outra consequência do reconhecimento da força normativa da Constituição é que, em razão da ubiquidade da Lei Fundamental, houve uma proliferação de trabalhos acadêmicos e decisões judiciais que buscam ampliar a racionalidade principiológica constitucional para diversos ramos e práticas jurídicas, o que leva Sarmento a afirmar que "hoje, além das grandes questões, a Constituição influencia também a resolução dos pequenos conflitos".

$\mathrm{Na}$ linguagem de Sarmento, esse processo de constitucionalização do direito deve-se à filtragem constitucional, mecanismo pelo qual "as normas constitucionais são irradiadas para os diversos ramos do Direito, impondo a releitura dos seus conceitos e institutos" ${ }^{25}$. Os direitos fundamentais, as normas programáticas e os princípios mais gerais - dignidade da pessoa humana, solidariedade social etc. - são considerados os parâmetros mais relevantes no trabalho hermenêutico de conferir efetividade às promessas constitucionais. É nesse contexto que o autor comemora as transformações nas áreas do direito civil e administrativo decorrentes dessa penetração constitucional. A aplicação horizontal dos direitos fundamentais e a possibilidade de revisão do mérito administrativo dos atos administrativos, por exemplo, são fenômenos vistos com entusiasmo por Sarmento.

Para o autor, o Neoconstitucionalismo surge como uma teoria que busca explicar e defender essa mudança cultural decorrente da adoção de um processo de filtragem constitucional mais efetivo a partir de 1988. Os fenômenos que compõem essa nova forma de enxergar o Direito são assim por ele catalogados:

\footnotetext{
concebe uma visão que conecte o Direito com exigências de justiça e moralidade crítica, sem enveredar por categorias metafísicas.

${ }^{24}$ SARMENTO, 2009, p. 127.

${ }^{25}$ SARMENTO, 2007, p. 134.
} 
(a) reconhecimento da força normativa dos princípios jurídicos e valorização da sua importância no processo de aplicação do Direito; (b) rejeição do formalismo e recurso mais frequente a métodos ou "estilos" mais abertos de raciocínio: ponderação, tópica, teoria da argumentação etc.; (c) a constitucionalização do Direito, com a irradiação das normas e valores constitucionais, sobretudo os relacionados aos direitos fundamentais, para todos os ramos do ordenamento; (d) reaproximação entre o Direito e a Moral, com a penetração cada vez maior da Filosofia nos debates jurídicos; e (e) judicialização da política e das relações sociais, com um significativo deslocamento de poder da esfera do Legislativo e do Executivo para o Poder Judiciário $^{26}$.

Outro ponto destacado pelo autor nos dois textos é o caráter emancipatório dessa nova teoria constitucional. Segundo Sarmento (2007, p. 125-126), a cultura jurídica anterior alimentava o sentimento de que a ordem jurídica não favorecia as causas mais nobres, mas apenas protegia o status quo. O novo discurso, iniciado a partir da década de 90 prega um projeto de transformação social a partir da transposição dos princípios e valores constitucionais para o mundo real. Não por outro motivo conclui que " $O$ Neoconstitucionalismo alenta um ideário humanista, que aposta na emancipação humana pela via jurídica, através de um uso engajado da moderna dogmática constitucional" ${ }^{, 27}$. Na linguagem do jurista, o juiz passa a ser concebido como guardião das promessas civilizatórias. É com base nessa faceta otimista que Sarmento conclui, de maneira peremptória:

É óbvio que o intérprete pode e deve aplicar diretamente a Constituição às relações sociais, independentemente de mediação legislativa. É indiscutível que ele tem de interpretar o direito infraconstitucional à luz da Lei Maior, inclusive para repudiar exegeses mais óbvias do enunciado normativo interpretado, quando estas o tornem incompatível com a Constituição. É certo, também, que ele pode deixar de aplicar normas que, conquanto em geral compatíveis com a Constituição, produziriam, no caso específico, resultados a ela ofensivos ${ }^{28}$.

Não obstante seu claro posicionamento a favor das principais teses do Neoconstitucionalismo, Sarmento (2007, p. 140-141) tem consciência de que uma panconstitucionalização pode produzir impactos negativos na democracia brasileira. Entende que a Constituição não pode ser vista como a fonte de respostas para todas as questões jurídicas, mas que deve haver espaços de liberdade para que o legislador e os cidadãos exerçam a autonomia política e a autônima privada, respectivamente. A dificuldade de

\footnotetext{
${ }^{26}$ SARMENTO, 2009, p. 113-114.

${ }^{27}$ SARMENTO, 2009, p. 123.

${ }^{28}$ SARMENTO, 2007, p. 141.
} 
conciliar essa ideia com Neoconstitucionalismo, entretanto, é reconhecida pelo próprio autor. Para ele, em razão da adoção de uma concepção de Constituição que impõe condicionamentos materiais amplos e profundos ao legislador, o intérprete deve agir com cautela para preservar margens decisórias aos poderes políticos e aos próprios indivíduos.

Sarmento também tem consciência de que a filtragem constitucional, a partir do manejo de princípios constitucionais muito abertos que se expandem para todos os ramos da ordem jurídica, pode ser bem ou mal empregada. Por isso alerta que a euforia com os princípios pode derivar para um decisionismo judicial demagógico. Para evitar esse efeito deletério do Neoconstitucionalismo, o autor procura elaborar uma metodologia que limite o exercício da jurisdição constitucional. Em um plano abstrato, o jurista traça as seguintes balizas:

(a) emprego de uma metodologia racional, intersubjetivamente controlável e transparente, não só para aperfeiçoar as decisões, como também para evitar que elas sejam vistas pela sociedade como o fruto exclusivo dos caprichos e das predileções dos seus prolatores; (b) à democratização do próprio exercício da jurisdição constitucional, com abertura de seu procedimento à participação efetiva de novos atores sociais, através de medidas como o fortalecimento do papel do amici curiae e a realização mais frequente de audiências públicas; (c) à adoção, pelos juízes, de uma postura de moderação e respeito diante das decisões adotadas pelos demais poderes, em razão de seu lastro democrático-eleitoral ${ }^{29}$.

Já na interpretação constitucional propriamente dita, Sarmento (2007, p. 145-149) destaca dois pontos. O primeiro se relaciona com a necessidade de valorização da argumentação jurídica e da racionalidade prática, o que exige que a decisão não se restrinja ao âmbito da reflexão individual do intérprete, mas que represente o resultado de uma argumentação jurídica no qual todos os participantes são tratados como livres e iguais, saindo vencedor aquele que apresenta o melhor argumento. As decisões devem, portanto, ser devidamente justificadas, mostrando-se não só às partes do litígio, mas ao público em geral, que o resultado atingido é o que mais se adéqua à ordem jurídica e às particularidades do caso.

O segundo ponto diz respeito à valorização e ao respeito das regras jurídicas. Por definirem com maior precisão tanto o seu campo de incidência como as consequências jurídicas, as regras seriam extremamente importante para salvaguardar a segurança jurídica e a eficiência do ordenamento. Para Sarmento, é equivocado considerar que o ordenamento seja

\footnotetext{
${ }^{29}$ SARMENTO, 2007, p. 138-139.
} 
composto apenas por princípios, pois tal atitude contribui para um decisionismo, razão pela qual ele entende que uma regra não pode ser afastada injustificadamente ${ }^{30}$. Conclui o autor (2007, p. 147-148) ser "perfeitamente possível postular a força expansiva dos princípios e valores constitucionais, revisitando, à sua luz, as normas e os institutos do ordenamento infraconstitucional", ao mesmo tempo em que leva as regras a sério.

As preocupações de Daniel Sarmento com relação ao Neoconstitucionalismo são louváveis e em grande maioria coincidentes com a nossa opinião. A dificuldade reside nos incentivos criados pelas teses por ele defendidas, que conferem ampla liberdade interpretativa aos juízes. Sempre haverá bons e maus magistrados. O problema que se põe refere-se exatamente aos instrumentos postos à disposição do intérprete. Por mais que Sarmento seja crítico do oba-oba constitucional, o arsenal teórico-progressista por ele produzido de uma forma ou de outra estimula os efeitos negativos por ele combatidos. A definição que elabora sobre a constitucionalização do direito é bem ilustrativa desse ponto:

Sustenta-se que a irradiação das normas constitucionais por todo o ordenamento jurídico contribui para aproximá-la dos valores emancipatórios contidos nas constituições contemporâneas. A Constituição não é mais vista como uma simples norma normarum - cuja finalidade principal é disciplinar o processo de produção de outras normas. Ela passa a ser enxergada como a encarnação dos valores superiores da comunidade política, que devem fecundar todo o ordenamento jurídico. Neste modelo, cabe não só aplicar diretamente os ditames constitucionais às relações sociais, como também reler todas as normas e institutos dos mais variados ramos do Direito à luz da Constituição, emprestando-lhes o sentido que mais promova os objetivos e a axiologia da $\mathrm{Carta}^{31}$.

A partir dessa definição pergunta-se: como exigir respeito às decisões dos demais órgãos políticos se os valores superiores encarnados na Constituição devem ser aplicados diretamente? Como dar efetividade aos valores emancipatórios expressos em princípios ao mesmo tempo em que se prega a utilização de regras infraconstitucionais? Em suma, se o importante é o conteúdo das decisões, como pedir ao intérprete que respeite compromissos institucionais que estabeleçam resultados dos quais discorda?

\footnotetext{
${ }^{30}$ Esse raciocínio é exposto da seguinte forma por Sarmento (2009, p. 141): “A tendência atual de invocação frouxa e não fundamentada de princípios colide com a lógica do Estado Democrático de Direito, pois amplia as chances do arbítrio judicial, gera insegurança jurídica e atropela a divisão funcional de poderes, que tem no ideário democrático um dos seus fundamentos - a noção básica de que as decisões sobre o que os cidadãos e o Estado podem e não podem fazer devem ser tomadas preferencialmente por quem representa o povo e seja por ele escolhido".

31 SARMENTO, 2009, p. 143.
} 
Ao incumbir aos juízes a função de promover transformações sociais e conferir-lhes instrumentos jurídicos para tanto, Daniel Sarmento - assim como os demais neoconstitucionalistas - além de demonstrar desconforto com a democracia, aceita os riscos de suas teses desaguarem em decisionismos. Ao pregar o respeito às decisões políticas e às regras, não deixa claro quando que essa postura interpretativa deve prevalecer. Deve-se obedecer às regras somente quando se concordar com o seu conteúdo? Quando a visão emancipatória do Direito deve ceder para a ideia de regulação jurídica? A nosso ver, o Neoconstitucionalismo se apresenta como uma concepção jurídica que cultiva valores e impõe propósitos que são incompatíveis com as teses de autocontenção defendidas por Sarmento. Este o tema dos próximos capítulos. 


\section{Capítulo 3 - Neoconstitucionalismo como concepção jurídica}

\section{1 - Neoconstitucionalismo: mera descrição de um paradigma?}

Muito se discute sobre a função da teoria neoconstitucional. Há autores, como André Rufino do Vale, que afirmam que o Neoconstitucionalismo é "um conjunto de posturas teóricas que adquiriram sentidos comuns ao tentar explicar o direito nos Estados constitucionais [...] a partir do pós-guerra"1, o que o caracterizaria como uma descrição de um paradigma. Susanna Pozzolo já afirma que a doutrina neoconstitucional é, sobretudo, uma política constitucional que indica não só como o Direito é, mas como ele deveria ser, a partir de certa concepção de Constituição que "determina exigências e técnicas interpretativas que convergem em uma prática social e assim contribuem para redefinir ou reconfigurar o objeto interpretado" ${ }^{2}$.

Outros autores falam em várias formas ou acepções do Neoconstitucionalismo, destacando-se a classificação elaborada por Paolo Comanducci (2003, p. 83-86) muito difundida nos meios acadêmicos. Partindo da classificação de Norberto Bobbio acerca das acepções do positivismo jurídico, distingue três formas de Neoconstitucionalismo: o Neoconstitucionalismo teórico, que aspira apenas a descrever as conquistas relacionadas com o processo de constitucionalização do Direito; o Neoconstitucionalismo ideológico, que valora positivamente as conquistas do processo de constitucionalização, propugnando sua defesa e ampliação; e o Neoconstitucionalismo metodológico, que sustenta haver necessária conexão entre o Direito e a Moral ${ }^{3}$.

Antonio Cavalcanti Maia (2007, 148-157) endossa a classificação de Mazzarese, que distingue três possíveis sentidos ao termo Neoconstitucionalismo. No primeiro sentido, o Neoconstitucionalismo seria entendido como certo tipo de Estado de Direito caracterizado por determinada forma de organização política. No segundo sentido, representaria uma teoria do direito que explica o conteúdo de determinados ordenamentos jurídicos, descrevendo um

\footnotetext{
${ }^{1}$ VALE, 2007, p. 68.

${ }^{2}$ DUARTE; POZZOLO, 2006, p. 78.

${ }^{3}$ Segundo o autor, o positivismo metodológico sustenta que é possível identificar e distinguir o que o Direito é do que ele deveria ser. Dessa tese derivam dois corolários: a tese das fontes sociais do direito e a tese da inexistência de relação necessária entre o Direito e a Moral. Ao se negar esse pressuposto positivista, Comanducci identifica o Neoconstitucionalismo como uma versão contemporânea do jusnaturalismo, que pode ser compreendido de diversas formas, seja como uma tese de identificação do direito, como uma tese relativa à argumentação jurídica ou como uma tese da razão prática em geral. Cf. COMANDUCCI, 2003, p. 93-98.
} 
modelo de conhecimento e aplicação do direito dentro de um paradigma. Por fim, indicaria um fundamento normativo-ideológico que justifica esse modelo de Estado.

A despeito dessas classificações, o que parece ser essencial no pensamento neoconstitucional é uma opção interpretativa que foca em determinados elementos do ordenamento, caracterizando-os como expressão central da prática jurídica. Com efeito, a partir da análise feita no capítulo anterior, percebe-se haver uma constância temática nos trabalhos dos autores ditos neoconstitucionalistas. A crença na emancipação social por meio da jurisdição constitucional faz com que os diversos autores festejem os instrumentos que conferem uma maior liberdade aos juízes para interferir na realidade social. A aplicação direta da Constituição, a valorização dos princípios, a constitucionalização do ordenamento jurídico, a aplicação horizontal dos direitos fundamentais e a técnica da proporcionalidade são vistos com bastante otimismo por todos eles. Obviamente, essa manifestação de preferência por tais mecanismos é uma atitude valorativa por parte desses intérpretes. Da mesma forma, a crescente produção doutrinária sobre os referidos institutos, bem como suas aplicações aos casos concretos, não podem ser vistas como um desenvolvimento natural do constitucionalismo. Não são fatos puros, mas escolhas do intérprete.

O Ministro Eros Grau, por exemplo, não compartilha do entendimento de que o princípio da proporcionalidade possa servir de parâmetro de controle de constitucionalidade, ao contrário de muitos autores neoconstitucionalistas ${ }^{4}$. No julgamento da Ação Direta de Inconstitucionalidade $\mathrm{n}^{\circ}$. 855, o Ministro Eros Grau manifestou-se contrariamente ao entendimento firmado pela maioria dos membros do Supremo Tribunal Federal que declaravam a inconstitucionalidade material por violação à proporcionalidade da lei $\mathrm{n}^{\circ}$. 10.248/93 do Estado do Paraná, que obrigava os estabelecimentos que comercializassem Gás Liquefeito de Petróleo - GLP a pesarem, à vista do consumidor, os botijões ou cilindros entregues ou recebidos para substituição, com abatimento proporcional do preço do produto ante a eventual verificação de diferença a menor entre o conteúdo e a quantidade líquida especificada no recipiente. Eis o trecho que demonstra a preocupação do magistrado com relação a esse ponto:

[O] meu temor é com relação ao princípio da proporcionalidade, porque isso significa que estamos julgando o legislador, estamos a ele imputando um desvio legislativo. Nós temos competência para apreciar a constitucionalidade da lei, não se ela é boa ou má. E, independentemente de ser boa ou má, se não viola a Constituição, a única maneira de investir contra

\footnotetext{
${ }^{4}$ Sobre o tema confira a obra monográfica de Anderson Pedra (2006), que defende arduamente essa possibilidade de uso da interpretação constitucional.
} 
ela seria nós nos candidatarmos e participar do Poder Legislativo. O Poder Judiciário não pode praticar aquilo que Canotilho chama de 'desvio de Poder Legislativo,

O Ministro Cezar Peluso também se mostrou desconfortável com a utilização da proporcionalidade e da razoabilidade como parâmetros de controle. No julgamento da Medida Cautelar na Ação Direta de Inconstitucionalidade $\mathrm{n}^{\circ}$. 4.467, em que se discutia a constitucionalidade do art. 91-A, da lei 9.504/97, acrescentado pela lei 12.034/09, que previa a necessidade de apresentação de dois documentos de identificação - o título de eleitor e outro documento com voto - para que o eleitor fosse autorizado a votar no dia das eleições, o Pretório Excelso, por maioria de votos, entendeu que a chamada "dupla titulação" não seria medida razoável, motivo pelo qual fora declarada sua inconstitucionalidade. Em seu voto vencido, o então Presidente da Casa assim se manifestou:

Eu não me sinto, e digo isso com o maior respeito, autorizado a fazêlo [declarar a inconstitucionalidade da norma] por vários motivos. [...] [A] proporcionalidade, a razoabilidade e outros critérios e postulados de que se valha a doutrina, na verdade não são normas, porque não são regra nem princípio constitucional. São apenas critérios de interpretação de normas constitucionais, em caso de colisão [...]. Não há norma constitucional da razoabilidade, nem norma constitucional da proporcionalidade que pudesse estar sendo ofendida no caso.

Há outros casos que falseiam a tese de que o Neoconstitucionalismo é uma evolução natural do nosso sistema jurídico. Em maio de 2012, o Senador da República Ricardo de Rezende Ferraco impetrou o mandado de segurança $n^{\circ} .31 .386$ perante o Supremo Tribunal Federal, visando a assegurar seu direito de votar de forma pública e aberta nos processos de cassação de mandato parlamentar. A argumentação utilizada pelo impetrante, por valorizar excessivamente um princípio constitucional com vistas a promover uma mutação constitucional, tinha feições nitidamente neoconstitucionais, o que torna o caso interessante para a presente análise. Em suas razões, o parlamentar afirmou que o $\$ 2^{\circ}$ do art. 55 da Constituição Federal - regra constitucional que impõe, nos casos de perda de mandato parlamentar, o voto secreto dos membros da Casa a qual pertença aquele parlamentar submetido a processo disciplinar - estaria em descompasso com o princípio democrático. Segundo o parlamentar, a votação secreta impossibilita que os eleitores tomem conhecimento

\footnotetext{
${ }^{5}$ Supremo Tribunal Federal, Ação Direta de Inconstitucionalidade no ${ }^{\circ}$ 855, Min. Rel. Octavio Gallotti, julgada em 06/03/08, acórdão publicado no DJ-e de 27/03/09.
} 
de como votam os seus representantes, o que inviabilizaria a prestação de contas por parte do político.

Veja que, nesse caso, o jurisdicionado requereu que a Corte Constitucional afastasse uma regra constitucional concreta em razão de um princípio abstrato. O que se pregou, implicitamente, foi um aperfeiçoamento do sistema político-representativo, abolindo uma prática que o impetrante entende ser perniciosa, por via judicial. Além disso, por se tratar de matéria do interesse dos próprios políticos, restou subentendido na petição inicial que o processo político majoritário dificilmente iria modificar essa regra, razão pela qual seria justificável a intervenção da Corte. Seria uma transformação da sociedade no que tange ao seu procedimento político-representativo por meio de interpretação constitucional.

Em decisão liminar, o Ministro Celso de Mello reconheceu que a votação ostensiva em caso de perda do mandato seria a solução mais consentânea com o princípio democrático, mas concluiu que esse entendimento estaria em conflito com a regra constitucional, que prevaleceu no caso. O magistrado, apesar de entender que uma decisão no sentido contrário àquela tomada moralizaria de certa forma um dos procedimentos mais importantes no âmbito parlamentar, conteve o seu ímpeto de reforma e obedeceu às razões da regra existente. Em razão da importância desse julgado para o tema, pede-se vênia para colacionar um longo trecho do voto:

Na realidade, a pretensão mandamental ora em análise busca impor à Mesa Diretora do Senado Federal, mediante ordem judicial, a adoção de comportamento que dissente, frontalmente, da Lei Fundamental, que se qualifica, no contexto ora em exame, como o estatuto de regência que define $\underline{a}$ ordem ritual a ser necessariamente observada no procedimento político-administrativo de perda do mandato parlamentar, em cujo âmbito a Constituição não admite o voto dado "coram populo".

Vê-se, daí, que a matéria em causa, por implicar modificação do próprio texto constitucional, reclama solução de "jure constituendo", pois, enquanto não sobrevier reforma $\underline{d a}$ cláusula de sigilo prevista no $\$ \underline{\mathbf{2}}$. do art. 55 da Constituição, esse modelo revelar-se-á de necessária observância, estendendo-se, por isso mesmo, aos Estados-membros, cujos estatutos

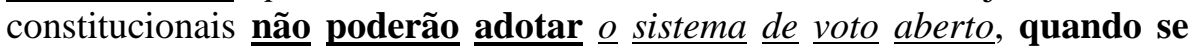
tratar de perda de mandato parlamentar, tal como decidiu o Plenário do Supremo Tribunal Federal no julgamento da ADI 2.461/RJ e da ADI 3.208/RJ, das quais foi Relator o eminente Ministro GILMAR MENDES $[\ldots]$.

Assinalo que fiquei vencido em tais argumentos na honrosa companhia do eminente Ministro MARCO AURÉLIO. Deixei consignado, então, em meu voto vencido, que a Assembleia Legislativa do Estado do Rio de Janeiro, ao consagrar $\underline{o} \underline{\text { modelo }} \underline{\text { de }} \underline{\text { votação aberta, nos }}$ procedimentos de perda de mandato parlamentar na esfera local, nada mais fez senão prestar integral reverência a dois postulados fundamentais $\underline{\text { e }}$ inerentes ao sistema político-jurídico que a Constituição da República 
consagrou: de um lado, o princípio da Federacão, que privilegia a essencial autonomia de que se acham impregnados os Estados-membros, $\underline{\mathbf{e}}$, de outro, o princípio democrático, que tem, na transparência $\underline{\text { e }} \underline{\text { na }}$ publicidade dos atos e deliberações que se formam no âmbito da comunidade estatal (inclusive no seio das corporações legislativas), um de seus mais expressivos valores ético-jurídicos.

Também entendo que a melhor solução, seja no plano federal, seja em âmbito local, sempre dependente, no entanto, de reforma do texto da Constituição da República (solução "de jure constituendo", portanto), como o revelam a PEC 50/2006 e a PEC 86/2007, traduzir-se-ia na adoção $\underline{d o}$

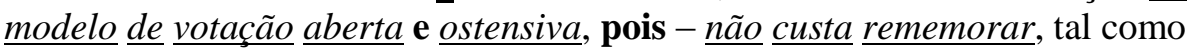
venho assinalando nesta Suprema Corte - os estatutos do poder, numa República fundada em bases democráticas, ñão podem privilegiar $\underline{o}$ mistério.

$\underline{\text { Ao }} \underline{\text { dessacralizar }} \underline{\text { o segredo, }}$ a Assembleia Constituinte restaurou velho dogma republicano e expôs o Estado, em plenitude, ao princípio democrático da publicidade, convertido, em sua expressão concreta, $\underline{\text { em }}$ fator de legitimação das decisões e dos atos governamentais.

Não posso, contudo, desconhecer o caráter impositivo da cláusula de sigilo que a Lei Fundamental da República instituiu no $\underline{\mathbf{\$} \mathbf{2}^{\mathbf{0}}}$ de seu art. $55^{6}$.

Por mais óbvio que possa parecer a conclusão do Ministro Celso de Mello, em razão da existência de uma regra constitucional a reger o assunto, o resultado poderia ter sido outro. Basta lembrar o precedente relativo à aplicação da Lei da Ficha Limpa à eleição que ocorreria no ano em que foi editada, citada na introdução deste trabalho, caso em que alguns membros do tribunal afastaram uma regra constitucional (art. 16 da Constituição Federal) face ao princípio da moralidade. Também não custa lembrar que, nos dois outros casos acima citados, a maioria dos membros do Supremo Tribunal Federal aceitou a utilização do princípio da proporcionalidade como parâmetro de controle da constitucionalidade de leis.

Enfim, como se vê, muitas das teses associadas ao Neoconstitucionalismo não são aceitas pelos magistrados, o que afasta a ideia de que essa corrente doutrinária apenas descreve um paradigma. Os juízes divergem quanto à sua função e aos métodos de interpretação constitucional da mesma forma que as pessoas discordam sobre política, moralidade ou economia. A adoção das teses neoconstitucionalistas consubstancia-se, portanto, em uma opção do intérprete, algo contingencial, que encerra uma porção de efeitos que não podem ser tratados como naturais ou logicamente necessários.

O Neoconstitucionalismo, ao se identificar com uma visão progressista da atividade jurisdicional, apresenta uma versão própria do fenômeno jurídico. Ou seja, o Neoconstitucionalismo não se restringe a descrever um modelo, mas também a prescrever

\footnotetext{
${ }^{6}$ Supremo Tribunal Federal, Medida Cautelar no Mandado de Segurança no . 31.386, Min. Rel. Celso de Mello, decisão ainda não publicada no DJ-e. (grifo do autor). Disponível em http://www.stf.jus.br/arquivo/cms/noticiaNoticiaStf/anexo/MS_31_386MCDF.pdf. Acesso em 19/07/12.
} 
uma atitude inspirada no modelo Brown que unifica o pensamento neoconstitucional em uma teoria jurídica que adota uma posição moralmente definida. Essa corrente doutrinária apresenta-se, assim, como uma interpretação da prática jurídica em que alguns elementos e valores são cuidadosamente pinçados para justificar a perspectiva emancipatória adotada. A metadistinção entre Neoconstitucionalismo teórico, ideológico e metodológico, ou qualquer outra análise que se utilize de um ponto de vista externo e neutro para analisar esse fenômeno jurídico, parece ser equivocada, devendo-se falar, na verdade, em uma concepção jurídica neoconstitucional que norteia a atuação do intérprete a partir de uma perspectiva interna. Esse ponto, a despeito de sua complexidade teórica, por ser essencial à compreensão da crítica que será feita ao Neoconstitucionalismo nos próximos capítulos, será mais bem desenvolvido nos tópicos seguintes.

\section{2 - Conceitos e concepções}

Herbert L. A. Hart, um dos mais importantes positivistas do último século, produziu várias contribuições para a nossa compreensão contemporânea sobre o Direito ${ }^{7}$. Uma delas se refere à distinção entre os pontos de vista interno e externo de um ordenamento jurídico. De acordo com Hart (1997, p. 88-91), o ponto de vista interno é aquele de um participante de uma determinada prática social que possui uma atitude crítica e reflexiva sobre os padrões de condutas adotados pelos membros da comunidade. Ele não somente consegue discernir e criticar os desvios, como também pressiona para que os demais membros ajam em conformidade com o padrão de conduta estabelecido, por considerá-lo justificado. Em se tratando da prática jurídica, o aspecto interno corresponde à atitude do cidadão que compreende e aceita as normas, utilizando-as como guias de condutas. A aceitação por parte do participante significa que ele não somente obedece ao que a norma prescreve, como também entende seu significado, considerando-a legítima, o que lhe permite emitir juízos de valor em caso de desvios ou descumprimentos do comando normativo ${ }^{8}$.

O ponto de vista externo é a perspectiva de um observador que examina a prática social de fora e que consegue, a partir da análise da regularidade de certas condutas, prever

\footnotetext{
${ }^{7}$ Para uma análise revisitada das teses de Hart, demonstrando a sua importância para o pensamento jurídico anglo-saxão, cf. GREEN, 1996.

${ }^{8}$ Hart (1997, p. 57) afirma que o que caracteriza o aspecto interno é uma atitude crítica reflexiva: "What is necessary is that there should be a critical reflexive attitude to certain patterns of behavior as a common standard, and that this should display itself in criticism (including self-criticism), demands for conformity, and in acknowledgements that such criticism and demands are justified, all of which find their characteristic expression. In the normative terminology of 'ought', 'must', and 'should', 'right' and 'wrong','.
} 
como os participantes agirão. Trata-se do ponto de vista daquele que descreve algo sem interferir no objeto: o ponto de vista de um cientista. Um membro que não aceita as normas de sua comunidade atua em conformidade com o padrão repetido pelos demais participantes em razão da ameaça de ser punido, não por utilizar as normas como guias de conduta. Essa atitude é aquilo que Hart convencionou chamar aspecto externo das normas jurídicas. Eis o trecho em que o positivista inglês procura esclarecer esses conceitos:

O seguinte contraste, de novo em termos de aspectos interno e externo das normas, pode servir para marcar o que confere a esta distinção sua grande importância para a compreensão não apenas do Direito, mas da estrutura de qualquer sociedade. Quando um grupo social possui certas regras de conduta, esse fato possibilita que muitas diferentes atitudes estreitamente relacionadas ocorram; é possível lidar com regras tanto como um mero observador que não as aceita ou como um membro do grupo que as aceita e as usa como guias de conduta. Podemos chamá-los, respectivamente, como pontos de vista externo e interno. [...] Após um período, o observador externo pode, com base nas regularidades observadas, fazer a correlação entre os desvios e reações hostis, tornando possível prever com um grau razoável de sucesso quais as chances de um desvio do padrão normal de conduta do grupo ser recebido por uma reação hostil ou por uma sanção. Esse conhecimento pode não só revelar muito sobre o grupo, como possivelmente permitirá que ele conviva com os demais sem as consequências indesejáveis sofridas por aquele que tentasse fazer a mesma coisa sem o mesmo conhecimento ${ }^{9}$.

Por essa distinção torna-se possível perceber que o positivismo jurídico é uma teoria que observa a prática jurídica a partir da perspectiva externa, buscando descrever de maneira geral os principais elementos que compõem o Direito ${ }^{10}$. Hart, por exemplo, define o Direito como um sistema formado por normas sociais primárias, que servem para direcionar e avaliar condutas, em conjunto com normas sociais secundárias, utilizadas na identificação, na modificação e na execução das normas primárias. Nessa empreitada, não se tenta justificar a existência do Direito em qualquer base moral ou política, nem se procura definir os seus objetivos ou finalidades. O positivismo jurídico, portanto, não tem a intenção de influenciar a prática jurídica, mas apenas esclarecer com neutralidade o mecanismo pelo qual o Direito opera em uma sociedade. Trata-se de projeto filosófico que não tem ambição prescritiva, mas meramente descritiva.

\footnotetext{
9 Tradução livre de HART, 1997, p. 90.

${ }^{10}$ Hart (1997, p. 239) deixa claro que sua teoria é, ao mesmo tempo, geral e descritiva: "It is general in the sense that it is not tied to any particular legal system or legal culture, but seeks to give na explanatory and clarifying account of lax as a complex social and political institution qith rule-governed (and in that sense 'normative') aspect”. Kelsen (2005, p. 1) também deixa claro que seu objetivo com a Teoria Pura é descrever o Direito: "As a theory, its exclusive purpose is to know and to describe its object. The theory attempts to answer the question what and how the law is, not how it ought to be".
} 
A ausência de uma parte normativa em seus trabalhos fez com que os principais autores positivistas não conseguissem explicar satisfatoriamente a atividade dos juízes ao decidirem os casos difíceis. Se, por um lado, Hart (1997, p. 141-147) concluiu que, nesses casos, em virtude da textura aberta das normas, os juízes possuem discricionariedade para determinar o seu sentido, por outro, Kelsen (2005, p. 352-354) afirmou que, em todos os casos, os órgãos encarregados de aplicar o Direito criam novas normas. Ocorre, entretanto, que essas explicações não conseguem apreender o modo como os juízes decidem os casos que lhes são apresentados. A atividade judicante sofre constrangimentos relacionados às razões estabelecidas em normas, princípios, doutrinas e precedentes, mesmo quando os magistrados parecem "criar" novos direitos. Afastadas as hipóteses em que se age de má-fé, é contraintuitivo imaginar que os juízes decidem quais os direitos as partes possuem de maneira discricionária e completamente desvinculada da história institucional pretérita.

Ademais, as pessoas normalmente consideram uma prática legítima a resolução de conflitos pela via judiciária. A necessidade de motivação das decisões judiciais faz com que os magistrados tornem públicas as razões pelas quais acreditam que a solução encontrada para o caso concreto é a que melhor se ajusta ao ordenamento jurídico. Essa necessidade argumentativa é aparentemente levada a sério pelos membros dos tribunais que demonstram se esforçar para decidir os casos corretamente. O positivismo parece ignorar esses dados. Ao descrever as decisões judicias como meros atos discricionários, as soluções positivistas mostram-se insatisfatórias.

O que levou os positivistas a camuflarem, em suas descrições, aspectos tão essenciais da prática jurídica? Por que a teoria positivista é tão irreal quanto à interpretação judicial? $\mathrm{O}$ âmago do problema reside na adoção de uma perspectiva externa para analisar o Direito, que impossibilitou aos positivistas esclarecerem uma ideia essencial para os participantes da prática social, que é o de normatividade jurídica. Explicar a razão pela qual devemos obedecer às normas jurídicas é uma questão que enseja discussão sobre o valor moral da legalidade, o que, evidentemente, é evitado pelos positivistas. Como consequência, sem identificar qual valor inspira a prática jurídica, não é possível definir como os juízes devem decidir os casos, dando ensejo às respostas amorfas apresentadas pelo positivismo ao problema da interpretação. Essas inconsistências nos levam a questionamentos mais gerais sobre o próprio projeto positivista. É possível se elaborar uma teoria puramente descritiva de uma prática social, como o Direito? Pode-se dizer que as teorias positivistas são, de fato, moralmente neutras? Há várias razões para se responder negativamente a essas perguntas. 
Em primeiro lugar, ao se elaborar uma teoria descritiva de uma prática social, há a necessidade de se escolher os elementos que fazem parte do seu caso central. Tal atitude, no entanto, demanda que se tenha um mínimo de compreensão sobre como funciona a prática analisada, o que exige que esses elementos sejam extraídos a partir de um ponto de vista interno, por parte de um participante. Isso porque somente quem está inserido no contexto de uma prática social possui condições de avaliar quais as características essenciais que a compõem. Hart, por exemplo, enumera uma lista de componentes que um jurista deve ser capaz de compreender a partir de uma teoria descritiva como a dele:

(i) regras proibindo certos tipos de condutas por meio de penalidades; (ii) regras impondo pessoas a compensarem aqueles a que elas causaram danos de certa forma; (iii) regras especificando o que deve ser feito para a realização de testamentos, contratos ou outros instrumentos que conferem direitos e criam obrigações; (iv) cortes que determinem quais são as regras e quando elas são violadas, além de fixar a pena e/ou a compensação a ser paga; (v) um Legislativo que faça novas leis e extinga outras velhas ${ }^{11}$.

Percebe-se que a elaboração de uma listagem como essa exige, no mínimo, uma précompreensão da prática que se pretende descrever. Assim, ao indicar quais elementos fazem parte do caso central da prática jurídica, Hart está de certa forma indicando quais são as características centrais de sua compreensão sobre o Direito. Um jurista brasileiro, por exemplo, envolvido em um projeto similar, provavelmente acrescentaria outros componentes ao caso central, como a jurisdição constitucional e as agências reguladoras. Noutro giro, os elementos identificados por Hart talvez fossem suficientes para se compreender o sistema jurídico inglês na década de 1950, mas insatisfatórios para uma análise de outro modelo, como o brasileiro. Isso significa que a análise por ele proposta não é tão geral e abstrata quanto pretende ser, mas voltada para uma prática social específica que ocorre dentro de determinado período e em certo local $^{12}$. De fato, não é possível dizer que as teorias positivistas, seja a de Kelsen ou a de Hart, sirvam para descrever o fenômeno jurídico em toda e qualquer sociedade. Os diferentes contextos históricos e culturais podem apresentar situações que não são bem representadas pelos modelos positivistas. A prática social de uma comunidade tribal, por exemplo, provavelmente não corresponde ao modelo positivista.

\footnotetext{
11 Tradução livre de HART, 1997, p.3.

${ }^{12}$ Dworkin (1986, p. 102) resume esse ponto concluindo que uma teoria do Direito como a proposta por Hart é uma interpretação de um estágio específico de uma prática historicamente desenvolvida, o que faz com que ela seja, na verdade, uma teoria a partir de um ponto de vista interno.
} 
Nesse sentido, por mais que a análise positivista tenha como foco apenas fatos, ou seja, sem perquirir as razões de moralidade política que justificam a prática social analisada, o ato de escolher quais os elementos que fazem parte do caso central a ser descrito não pode ser considerado algo neutro. O simples fato de considerar uma ou outra característica relevante em detrimento de outros aspectos torna a análise moralmente dependente ${ }^{13}$. Uma descrição de um fenômeno social, por mais fiel que seja, é sempre uma compreensão parcial do objeto, subordinado à visão subjetiva do intérprete. Não por outro motivo as descrições da prática jurídica diferem umas das outras, não havendo uma versão do positivismo jurídico que seja compartilhada por todos, mas um grande número de teorias que pretendem descrever o Direito da melhor maneira possível.

Em segundo lugar, uma análise conceitual que explique a inter-relação entre os diversos componentes referentes ao funcionamento interno de uma prática social necessariamente adota a perspectiva de um participante. Saber se uma norma jurídica é constitucional, por exemplo, é algo que somente os membros da prática social que tenham conhecimento sobre o assunto conseguem fazer. Quando Hart afirma que o ordenamento jurídico funda-se em uma regra de reconhecimento ou quando Kelsen estrutura sua teoria em uma norma fundamental hipotética, esses juristas não estão agindo passivamente, como um observador externo. Tais conceitos não derivam de um conhecimento empírico, mas de uma construção teórica que modifica o próprio objeto de estudo, isto é, uma teoria normativa. A regra de conhecimento ou a Groundnorm, antes de ser algo autoevidente, são conceitos bastante misteriosos para a maior parte dos juristas. $\mathrm{O}$ fato de esses autores tentarem elucidar o que ocorre na prática jurídica indica que eles não estão apenas descrevendo algo de fora, como bem salienta Stephen Perry:

Em primeiro lugar, o pensamento de que um debate [conceitual] pode ser necessário para estabelecer uma questão importante na teoria jurídica sugere que há algo mais aqui do que uma mera descrição de uma prática social. Em segundo lugar e relacionado, um debate como esse parece ser mais bem interpretado como sendo não entre dois observadores de fora, mas entre dois participantes que discordam, em bases filosóficas e não empíricas, sobre a natureza fundamental da prática ${ }^{14}$.

\footnotetext{
${ }^{13}$ No caso de Hart (1997, p. 91-4), a existência de juízos moralmente relevantes fica mais evidente quando ele afirma que o sistema de regras primárias é aperfeiçoado com as regras secundárias de reconhecimento, sanando os vícios de ineficiência, incerteza e imutabilidade. Nesse caso, Hart não está valorando diferentes teorias, mas a própria prática que ele está observando. Ao realizar esse tipo de julgamento, não se pode afirmar de maneira plausível que sua teoria é meramente descritiva.

${ }^{14}$ Tradução livre de PERRY, 2005, p. 335.
} 
Logo, a descrição de uma prática social, para ser realmente consistente com a adoção de um ponto de vista externo, somente poderia expor a existência de comportamentos que seguem determinado padrão, fazendo uma análise de causa e efeito. Caso haja divergências filosóficas sobre o significado de algum elemento interno da prática, como o conceito de obrigação jurídica, tal fato jamais poderia ser noticiado por uma teoria realmente positiva. No entanto, ao elucidar-se o modo como determinada prática é compreendida pelos seus participantes, tornando transparentes os elementos nela envolvidos, está-se adotando um ponto de vista interno. A metodologia empregada na ciência para descrever os fenômenos naturais, quando aplicados a uma prática social, como pretendem Hart e Kelsen, não poderiam se desdobrar em explicações conceituais. A percepção de que os juízes criam normas ou que possuem discricionariedade ao decidirem os casos legais, por exemplo, é algo que somente quem faça parte da prática social e entenda o funcionamento das normas teria condições de testemunhar. Tal constatação permite afirmar que qualquer teoria, por mais neutra que tente ser, consubstancia, de certa forma, uma versão específica sobre a prática jurídica analisada a partir de uma perspectiva interna ${ }^{15}$.

Em terceiro e último lugar vale questionar, seguindo Dworkin (2006, p. 140-186), qual a utilidade de uma teoria meramente descritiva de uma prática social ou de um conceito político, como a democracia, a justiça, a liberdade, a igualdade e o Direito. O argumento normalmente utilizado para justificar esses projetos filosóficos é o de que eles serviriam para fixar pontos de acordo sobre o que se pretende estudar. Eles forneceriam, assim, o conhecimento prévio e necessário para a elaboração de qualquer crítica sobre o assunto ${ }^{16}$. Ocorre que, em se tratando de conceitos que encarnam valores, a utilização de definições baseadas em descrições neutras torna-se bastante limitada.

Quando se discute, por exemplo, se a prática de controle de constitucionalidade é, ou não, antidemocrática, o que está em jogo é o valor inerente à democracia. Acredita-se que a

\footnotetext{
${ }^{15}$ As conclusões de Stephen Perry (2005, p. 353-354) são elucidativas a esse respeito: "The substantive difficulties faced by Hart's theory thus have methodological roots. The related philosophical goals of analyzing the concept of law and addressing the problem of the normativity of law are plausible and appropriate ones for legal theory, but they cannot be accomplished by taking an external, purely descriptive approach. Hart seems to have borrowed the idea of a purely descriptive theory from the methodology of science, which is a very different kind of theoretical enterprise from philosophy. The result, from a methodological perspective, is an unsatisfactory hybrid. Of course I do not mean to deny that it is possible to describe a social practice in a more or less neutral fashion and from an external point of view. [,,,] [T] here are indefinitely many descriptions that can be offered of any given practice, although most of them are entirely lacking in interest or theoretical significance”.

${ }^{16}$ Hart (1997, p. 240), por exemplo, em seu pós-escrito, afirma que a sua teoria descritiva cumpriria um papel diferente e serviria de base para as normativas, como a de Dworkin: "My account is descriptive in that it is morally neutral and has no justificatory aims; it does not seek to justify or commend on moral or other ground the forms and structures which appear in my general account of law, though a clear understanding of theses is, I think an important though preliminary to any useful moral criticism of law'.
} 
democracia é importante, mas há desacordos sobre qual concepção de democracia melhor expressa essa sua importância. Há concepções formais e substantivas, sendo que os defensores de cada posicionamento procuram demonstrar a razão pela qual o seu ponto de vista é o que melhor espelha o valor inerente a esse conceito político. Dentro dessa perspectiva, aqueles que adotam uma concepção substantiva provavelmente concluirão que o controle de constitucionalidade é sempre legítimo na medida em que impede que a maioria produza resultados injustos. Já os adeptos da concepção formal entenderão que a jurisdição constitucional somente se justifica se for praticada com vistas a resguardar a lisura do processo político. Uma pessoa que ignorasse esse debate e simplesmente utilizasse uma definição puramente descritiva de democracia como regra da maioria para concluir que a jurisdição constitucional é uma prática antidemocrática apresentaria um argumento pobre e inadequado sobre o assunto.

Isso porque o termo democracia, assim como os demais conceitos políticos, não é neutro, sendo utilizado para valorar certas práticas e institutos. O significado moral do termo é relevante para quem o utiliza. Dworkin (2006, p. 145-154) alerta, nesse sentido, que os filósofos devem ou deveriam estar cientes de que os conceitos por eles analisados são de uso corrente nas discussões do dia a dia e não restritos aos ambientes acadêmicos. Quando se diz que a China não é um país democrático ou que a legalidade foi restaurada no Iraque, esses termos são utilizados de forma valorativa, o que indica que eles necessariamente possuem uma dimensão normativa.

O conceito de Justiça é elucidativo a esse respeito. Como elaborar uma descrição externa sobre os elementos que fazem parte do que se considera justo sem se tomar uma posição? Como descrever o que é Justiça sem explicar o que é ser justo? Um utilitarista, por exemplo, relatará que a maximização da felicidade ou de riqueza é elemento integrante desse conceito, enquanto os partidários da deontologia responderão que o respeito à dignidade humana é o que a caracteriza. Ao fazer tais descrições, os filósofos estarão revelando as características centrais de sua visão substantiva sobre o assunto.

Quando as pessoas divergem sobre o que é justo ou democrático, não estão discordando sobre quais elementos fazem parte de um conceito de Justiça ou de democracia, mas sobre qual a versão apresentada pelos interlocutores que melhor captura ou realiza o valor essencial desses conceitos. Cada participante procura apresentar as razões pelas quais considera sua perspectiva superior às dos demais, recorrendo a argumentos valorativos. $\mathrm{Ou}$ seja, cada um procura demonstrar o que os valores subjacentes ao conceito propriamente 
compreendido requerem. Trata-se de um debate eminentemente substantivo, ao invés de descritivo.

Dworkin argumenta que essa atitude crítica e reflexiva acerca dos conceitos políticos é mais bem compreendida como uma interpretação construtiva, atividade em que os membros da comunidade expressam os seus pontos de vista por meio de diferentes concepções morais sobre o mesmo objeto. Essa atitude interpretativa, conclui Dworkin, é a metodologia de fato utilizada para "desvendar" a essência de conceitos políticos, como o Direito e a democracia, por mais que os teóricos pareçam ou almejem descrever algo. Não reconhecer essa natureza de seu projeto acadêmico seria uma falha das teorias positivistas.

\section{3 - O Direito como um conceito interpretativo}

A partir da constatação acima referida, Dworkin afirma que qualquer teoria jurídica é mais bem compreendida como um esforço interpretativo no qual se busca apresentar o Direito em sua melhor versão moral. Nesse processo, o intérprete, ao mesmo tempo em que descreve, justifica essa prática social, salientando os valores que a tornam legítima. Por esse motivo, Dworkin (2002, p. viii) conclui que "uma teoria geral do direito deve ser ao mesmo tempo normativa e conceitual'. Nessa perspectiva, o Neoconstitucionalismo deve ser visto como uma teoria que é simultaneamente normativa e conceitual, elaborada a partir do ponto de vista do participante, o que impossibilita cindi-lo em Neoconstitucionalismo teórico, ideológico e metodológico, ou classificá-lo como uma descrição de um paradigma. O Direito é um conceito interpretativo que dá ensejo a várias concepções distintas a depender dos valores a ele atribuídos, sendo o Neoconstitucionalismo uma dessas concepções.

O processo de criação de uma concepção jurídica é uma construção interpretativa complexa no pensamento dworkiano, o que exige o esclarecimento de alguns pressupostos antes de examinar especificamente a doutrina neoconstitucional. Em primeiro lugar, torna-se imperioso compreender em que consiste a atitude interpretativa levada a cabo por teóricos ao elaborarem suas concepções. Essa atitude é explicada da seguinte maneira pelo autor norteamericano:

O primeiro passo é assumir que a prática [...] não apenas existe, mas possui um valor, ou seja, que serve a algum interesse ou propósito ou enfatiza algum princípio - em resumo, que possui uma razão de ser - que pode ser declarado independentemente de somente descrever as regras que fazem parte da prática. O segundo passo é assumir que os requisitos (da prática) - o comportamento que ela enseja ou os julgamentos que ela permite 
- não são necessária ou exclusivamente da forma como eles têm sido praticados, mas, em vez disso, sensíveis à sua razão de ser, de maneira que as suas regras devem ser compreendidas ou aplicadas ou estendidas ou modificadas ou qualificadas ou limitadas pelo seu propósito. A partir do momento que se inicia a atitude interpretativa, a prática [...] deixa de ser mecânica; ela não mais se apresenta como uma deferência irrefletida a uma ordem antiquada. As pessoas passam a tentar impor um significado à instituição - a vê-la em sua melhor forma - e, então, reestruturá-la à luz desse significado ${ }^{17}$.

Assim, para Dworkin, uma prática social como a prática jurídica deve ser interpretada como voltada para um propósito, ao invés de algo meramente causal. Uma interpretação construtiva constitui na atribuição de um valor ou de um significado ao objeto pesquisado, a fim de enxergá-lo como o melhor exemplo possível de sua classe. Obviamente, o formato e a história do objeto restringem as opções possíveis, sendo a interpretação um processo delicado de interação entre o objeto e o seu propósito. Essa atitude exige que quem a faça participe efetivamente da prática que se propõe a compreender, de maneira que a sua conclusão não é um mero relato sobre como as pessoas se portam, mas uma verdadeira teoria sobre o significado do objeto investigado, versão esta que sempre se encontra em regime de concorrência com outras elaboradas pelos demais participantes.

De maneira geral, a atitude interpretativa é dividida em três estágios por Dworkin (1986, p. 65-66). Em primeiro lugar, há a fase pré-interpretativa, na qual são identificados os principais elementos que compõem o objeto a ser investigado. Os paradigmas, entendidos como os casos centrais da prática, devem necessariamente fazer parte desse material coletado. Em segundo lugar, há a fase interpretativa, em que os participantes estabelecem uma justificativa geral para os principais elementos identificados no estágio anterior, argumentando porque a prática no formato apresentado é digna de valor. Dworkin afirma que nem todos os elementos identificados na fase pré-interpretativa devem se ajustar perfeitamente à justificativa elaborada. É, no entanto, necessário que eles se adéquem de tal forma que seja possível afirmar que o que se está interpretando é aquela prática específica, e não uma nova criada pelo intérprete, o que exige que pelo menos os paradigmas sejam justificados. Em terceiro lugar, há uma fase pós-interpretativa ou construtiva, na qual o intérprete emite um juízo crítico sobre como a prática deveria evoluir para melhor se adequar à justificativa dada no estágio interpretativo, sugerindo a exclusão dos elementos que não se coadunam com os valores que embasam a conclusão.

\footnotetext{
${ }^{17}$ Tradução livre de DWORKIN, 1986, p. 47.
} 
Dworkin observa que, na prática, as interpretações elaboradas pelas pessoas em seu cotidiano não obedecem à lógica das três etapas. O participante que apresenta a sua visão sobre determinado assunto indica o propósito e as consequências pós-interpretativas desse propósito em uma só dimensão, na forma de um argumento geral. Essa divisão em diferentes estágios, elaborada por Dworkin, serve apenas para elucidar o desenvolvimento do raciocínio interpretativo. $\mathrm{O}$ autor também sugere que esse processo não evita que diferentes pessoas alcancem resultados diversos, concluindo que a interpretação construtiva não é um método. Ao elaborar suas concepções jurídicas, os membros da comunidade irão discordar sobre o significado da prática, o que gerará discordâncias conceituais sobre qual concepção apresenta o Direito em sua melhor forma.

O Direito, assim, apresenta-se como um conceito político interpretativo que convida os seus participantes a refletir e a criticar sobre o que essa prática realmente requer. Ao elaborar suas conclusões, os intérpretes atribuem valores e propósitos à prática jurídica como um todo, explicitando a justificativa moral que legitima o uso de força política por parte dos juízes. Para Dworkin, a questão principal da filosofia do Direito não é descrever quais elementos compõem o seu conceito, mas responder o que torna uma proposição jurídica válida e aceitável para os membros da comunidade. Ao contrário dos positivistas, que afirmavam que o fundamento de uma proposição jurídica é uma questão de fato (se há, ou não, alguma fonte oficial que estabeleça os direitos requeridos), Dworkin afirma que essa é uma questão eminentemente teórica: ao elaborar suas proposições jurídicas as partes interpretam a prática jurídica, resgatando os valores morais que a justificam como um todo, transplantando essa justificativa geral sobre o Direito para as questões particulares ${ }^{18}$.

Um exemplo utilizado por Dworkin (2006, p. 7-9) talvez seja elucidativo nesse ponto. Em um caso fictício, a Sra. Sorenson, após consumir durante vários anos um remédio para artrite, sofre um grave problema cardíaco em razão de um efeito colateral da droga não antevisto. Durante o período em que utilizou a medicação, a Sra. Sorenson comprou o mesmo produto de várias das dez indústrias farmacêuticas que fabricavam o mesmo fármaco. Ao

18 Gregory Keating (1987, p. 526-527) afirma que é possível compreender o projeto de teoria do Direito elaborado por Dworkin a partir da forma como são decididos os casos difíceis. Segundo o referido autor: "The shortest way to explain content of the theory is by saying that it applies Dworkin's conception of legal reasoning in hard cases to the general problems of legal theory. Hard cases arise when the law's shock of settled rules and rulings is insufficient to resolve a dispute - either because those rules conflict and so suggest competing answers, or because they are incomplete and so silent on the issue presented by the case at hand. Such cases force judges to reconstruct the fabric of moral principles which underspins the law's black-letter rules and doctrines and to fashion out that fabric a new and purer vision of what law might be. Hard cases are the law in quest of itself, the law's pursuit of self-understanding. Legal theory is this enterprise write large: it seeks not the deepest ideals of tort law or constitutional law, but the core of legal practice”. 
ingressar com ação judicial buscando recompor os danos sofridos, entretanto, ela não teve condições de apontar claramente qual empresa produziu os comprimidos que ela ingeriu: indubitavelmente consumiu o medicamento de mais de uma empresa, mas, por outro lado, há empresas a que ela jamais comprou o produto. Apesar disso, não consegue recordar exatamente de quais comprou e agora não tem mais condições de apurar esse fato. $\mathrm{O}$ advogado dela resolve, então, ingressar com uma ação indenizatória contra as dez empresas que produziam o medicamento durante o período em que ela consumiu a droga, alegando que, por não ser possível identificar quem produziu cada pílula utilizada, deve ser entendido que todas as empresas são juridicamente responsáveis pelo pagamento de danos na proporção de sua fatia no mercado em razão da negligência de todas elas em não pesquisar adequadamente os efeitos gerados pelo remédio posto à venda.

Suponha que só há uma norma jurídica geral sobre responsabilidade civil, afirmando que aqueles que causam danos são responsáveis pela recomposição do prejuízo e que em alguns precedentes tenha sido estabelecido o entendimento de que ninguém pode ser condenado por danos que não tenha diretamente causado. Os advogados das empresas farmacêuticas argumentarão que há um princípio jurídico institucionalizado em precedentes que afirma que ninguém pode ser responsabilizado por danos sem que haja comprovação do nexo de causalidade, razão pela qual a ação deve ser julgada improcedente. Os advogados da Sra. Sorenson, por outro lado, discordarão, em réplica, afirmando que a situação do caso se distingue da do precedente citado, pois o princípio mencionado não se aplica ao direito do consumidor. Para eles, a teoria do risco, que afirma que as empresas são objetivamente responsabilizadas pelos prejuízos decorrentes dos produtos lançados no mercado, é a melhor solução jurídica para o caso. Na defesa de seu argumento, a autora demonstra que esse é o princípio legal endossado pelo ordenamento jurídico em várias áreas em que há uma desigualdade material entre as partes, como na relação entre o particular e o Estado, e sustenta que, por uma questão de coerência, seria injusto não reconhecer a aplicabilidade desse princípio ao seu caso.

Nessas circunstâncias, qual proposição jurídica é a mais correta? Qual a natureza da discussão? Dworkin afirma que a decisão neste caso não poderá ser uma questão meramente de fato, como defende o positivismo, pois ambas as partes apelam para princípios de moralidade política para justificar seu argumento. Nenhuma das duas partes se restringe a alegar a existência de um fato histórico, como uma lei ou um precedente, que estabeleça definitivamente o direito de uma das partes. Os argumentos jurídicos elaborados pelas partes são muito mais complexos. O juiz, ao decidir essa causa, terá que avaliar qual dos dois 
posicionamentos se mostra mais condizente com os valores e os propósitos que, a seu ver, melhor justificam a prática jurídica de maneira global, encaixando a decisão do caso numa rede coerente de princípios. Em uma disputa jurídica, portanto, os argumentos jurídicos e morais estão sempre imbricados: busca-se identificar a melhor justificativa da prática e das normas existentes com vistas a projetá-la ao caso presente.

No exemplo apresentado, o magistrado necessariamente terá que decidir se o princípio de que ninguém pode ser responsabilizado por algo que não cometeu é a melhor justificativa para as relações de consumo ou se há uma particularidade nesse tipo de relação jurídica que impõe uma leitura a partir do princípio da solidariedade, também reconhecido pelo ordenamento, segundo o qual a empresa que provoca riscos deve arcar com os prejuízos decorrentes de sua atitude negligente. A escolha jurídica será entre seguir o precedente ou distingui-lo por ausência de identidade de fundamento. Adotando um ou outro posicionamento, o magistrado necessariamente fará uma decisão política: endossará certos valores morais que, a seu ver, melhor justificam a relação consumerista, rejeitando concepções concorrentes. Essa decisão, todavia, deverá ser coerente com o restante do material jurídico existente e, de maneira geral, com os valores subjacentes à prática jurídica como um todo, em um equilíbrio reflexivo amplo e geral ${ }^{19}$. Ao elaborar uma sentença, portanto, o juiz faz um exercício interpretativo de justificação para o caso concreto análogo ao de um filósofo do Direito que tenta dar à prática jurídica um sentido ou propósito geral. Nesse sentido, Dworkin afirma:

Teorias gerais do Direito [...] devem ser abstratas porque elas objetivam interpretar o principal ponto e estrutura da prática jurídica, não apenas uma parte específica ou um setor dela. Apesar de sua abstração, elas são interpretações construtivas: elas tentam mostrar a prática jurídica em seu melhor ângulo, para obter o equilíbrio entre a prática jurídica como ele se encontra e a melhor justificativa dessa prática. Então, não há nenhuma linha divisória que diferencie a teorização sobre o Direito e o ato de julgar ou qualquer outro aspecto da prática jurídica. Os filósofos do Direito debatem sobre a parte geral, o fundamento interpretativo que qualquer argumento jurídico deve ter. É possível olhar o outro lado da moeda. Qualquer argumento jurídico, não importa o quão detalhado ou limitado seja, assume o tipo de abstração que a teoria do Direito oferece, e quando fundamentos rivais competem, o argumento jurídico endossa um e rejeita o outro. Assim, qualquer sentença é um pouco de filosofia do Direito, mesmo quando a

\footnotetext{
${ }^{19} \mathrm{O}$ conceito de equilíbrio reflexivo foi inicialmente elaborado por John Rawls (2003, p. 42-44) para designar "uma coerência entre convicções refletidas em todos os níveis de generalidade”, desde "juízos específicos sobre as ações singulares de indivíduos a juízos sobre a justiça e injustiça de determinadas instituições e políticas sociais, terminando com juizos sobre convicções extremamente gerais”. Ronald Dworkin já confessou que a ideia de equilíbrio reflexivo permeia a sua teoria de direito como integridade. Cf. DWORKIN, 2006, p. 241-261.
} 
filosofia está escondida e o argumento visível está revestido de citações jurisprudenciais e fatos. A teoria do Direito é a parte geral da interpretação judicial, um preâmbulo silencioso de qualquer decisão jurídica ${ }^{20}$.

Nesse diapasão, todo argumento jurídico exige que o intérprete reconstrua o fundamento que, a seu ver, justifica a prática jurídica em sentido global para, então, aplicar a sua teoria à situação específica. É nesse sentido que Dworkin (2006, p. 12-18) divide todo argumento jurídico em duas etapas: teórica e doutrinária. Em um primeiro momento, há a fase teórica, em que são indicados os valores que explicam a prática jurídica como um todo. Busca-se responder a uma questão mais ampla: quais princípios justificam os arranjos de poder e de autoridade na sociedade em questão? A resposta a essa pergunta fornecerá justificativas que, por coerência, limitarão a utilização da força estatal por parte dos juízes ao decidir sobre direitos jurídicos concretos. Somente argumentos jurídicos compatíveis com os propósitos estatais considerados legítimos podem ser utilizados como fundamentos jurídicos válidos. Assim, a partir da identificação desses valores gerais, torna-se viável, em um segundo momento (fase doutrinária), construir um critério de correção das proposições jurídicas que norteará a atividade do intérprete ao analisar questões concretas.

Há, ainda, uma complexidade adicional na estrutura de um argumento jurídico no pensamento dworkiano. Uma interpretação construtiva da prática jurídica, para ser bemsucedida, deve satisfazer a duas exigências muitas vezes conflitantes: ao mesmo tempo em que a interpretação necessita ser compatível com a maior parte do material jurídico existente, deve apontar os valores que servem à prática jurídica e que devem nortear seu desenvolvimento. A função de uma concepção jurídica, portanto, é dar sentido à prática jurídica como ela se encontra, e não inventar uma nova. Mesmo restringindo o campo interpretativo dessa forma, há diversas versões possíveis a depender dos valores escolhidos pelos intérpretes $^{21}$. Quem defende que a melhor leitura é aquela em que o Direito serve à eficiência na coordenação das condutas advogará pela manutenção das normas e precedentes já estabelecidos. Já os que atribuem à prática jurídica o valor de justiça substancial defenderão

\footnotetext{
${ }^{20}$ Tradução livre de DWORKIN, 1986, p. 90.

${ }^{21}$ Dworkin (2006, p. 169) explica que cada escolha de valores inerentes à legalidade dá ensejo a concepções jurídicas distintas que, consequentemente, desembocam em proposições jurídicas concorrentes: "The value must nevertheless function, within our community, as an interpretative value - those who accept it as a value must nevertheless disagree about precisely what value it is, and must disagree, in consequence, at least to some degree, about which political arrangements satisfy it, or which satisfy it better and which worse. It must be a distinctly legal value so fundamental to legal practice that understanding the value better will help us better to understand what claims of law mean and what makes them true or false. We must be able to see, for example, how a specific conception of value would generate the sources thesis, and how other conceptions would generate the very different theories of law that are also part of the literature of jurisprudence".
} 
uma atuação judicial reformista, modificando com mais facilidade os compromissos institucionalmente firmados no passado. Todas essas condicionantes vão influenciar na elaboração final de um argumento jurídico.

Por trás dessa tensão entre manutenção e modificação do ordenamento jurídico há uma questão valorativa que deve ser equacionada pelo intérprete na fase teórica de seu raciocínio. Uma concepção jurídica satisfatória deve ser capaz de explicar o arranjo constitucional atual e os procedimentos democráticos existentes, indicando como se deve dar a interação entre esses elementos e os processos de transformação social via Judiciário. Essa questão é capturada por Dworkin por meio da elaboração as dimensões da adequação e da justificação inerentes ao argumento jurídico:

Olhamos para o Direito como um todo para propor interpretações que resolvam os casos iminentes, satisfazendo as duas dimensões [...], a dimensão da adequação e a dimensão da justificação. [...] A diferença entre adequação e justificação não é que a adequação seja algo mecânico e a justificação algo normativo. A diferença, como eu entendo, e acho que passei a entendê-la melhor ao longo dos anos, é uma distinção entre dois conjuntos de valores políticos que se encaixam naturalmente nas descrições de "valores procedimentais" e "valores substantivos". [...] O contraste entre adequação e justificação pode ser mais precisamente resumido no contraste entre valores procedimentais - como algo passou a ser um compromisso? -e o valor do próprio compromisso - quão perto esse compromisso está de uma justiça substantiva e em que sentido gostaríamos que a sociedade fosse comprometida? O julgamento global, no qual várias pessoas irão discordar, é, assim, um julgamento de moralidade política que possui particularidades e também nos chama a emitir um juízo sobre a importância dessas duas dimensões no julgamento global sobre como compreendemos a nossa sociedade $^{22}$.

Percebe-se, pois, que o modo como são dosados os valores em uma concepção jurídica vai indicar o peso dado às dimensões da adequação e da justificação pelo intérprete ${ }^{23}$. Aqueles que foquem sua perspectiva na legitimidade dos procedimentos de elaboração e aplicação das normas jurídicas elaborarão proposições jurídicas mais voltadas para a manutenção dos compromissos assumidos pela sociedade, enquanto juristas mais preocupados em discutir a substância dos compromissos naturalmente irão se mostrar mais favoráveis a argumentos que propiciem uma maior revisão judicial desses compromissos. É óbvio que há inúmeras formas de misturar esses elementos. Uma concepção jurídica será considerada bem-sucedida se

\footnotetext{
${ }^{22}$ Tradução livre de DWORKIN, 2004, p. 15-16.

${ }^{23}$ Nesse sentido, explica Dworkin (2006, p. 172): "Nevertheless different conceptions will select different connected values as more important in that mix: conceptions will differ, we might say, in the importance each assigns to different values in creating the local magnetic field in which it places legality. Schools or traditions of jurisprudence are formed by large differences in the character of those choices".
} 
conseguir encadear de maneira consistente esses valores em uma versão moralmente atrativa da prática jurídica, o que exige que nenhuma das duas dimensões seja totalmente desprezada. Dito de outra forma, não se pode renegar por completo o material jurídico existente nem impedir de maneira peremptória a evolução do sistema com base em novas interpretações.

Essa, pois, a estrutura básica de uma concepção jurídica: trata-se de uma interpretação da prática jurídica em que se impõem valores que justifiquem a utilização do poder estatal por parte dos juízes, tornando-a moralmente atraente. Estabelece-se, assim, um balanço entre as dimensões da adequação e da justificação que norteará o agir do intérprete, restringindo-se, de um lado, o espaço criativo, apontando-se, por outro, as condições e os rumos do desenvolvimento judicial do Direito. Em razão do equilíbrio reflexivo entre os diversos níveis de abstração do argumento jurídico, chamado por Dworkin de integridade, torna-se possível, a partir desse passo teórico geral, elaborar argumentos doutrinários para partes específicas do Direito, já que há a reprodução desses mesmos padrões valorativos gerais nas proposições jurídicas elaboradas para solucionar problemas específicos.

Desvendada a estrutura interpretativa por Ronald Dworkin, será feita, no capítulo seguinte, uma análise das teses defendidas pelo Neoconstitucionalismo no intuito de identificar os valores inerentes a essa concepção, bem como analisar o balanço dado por seus adeptos às dimensões da adequação e da justificação. 


\section{Capítulo 4 - Juízes neoconstitucionalistas}

\section{1 - Definindo a abordagem}

Como os juízes devem decidir os casos que lhes são apresentados? Qual a importância que deve ser dada à dimensão de adequação e à de justificação? Quando é que se mostra legítima a modificação dos compromissos assumidos pela sociedade por meio de uma interpretação judicial? Essas as principais questões respondidas por uma teoria do Direito. Entretanto, não é preciso que os juristas elaborem em alto grau de abstração seus argumentos para identificar as concepções adotadas. Como se viu no capítulo anterior, em razão da ideia de coerência e de equilíbrio reflexivo que perfazem o raciocínio jurídico, é possível inferir das proposições jurídicas específicas os valores que compõem uma concepção jurídica geral. A atitude interpretativa, ainda que limitada a uma situação isolada, exige a reconstrução dos propósitos da prática jurídica como um todo, o que permite analisar criticamente a versão desenvolvida pelos diversos participantes. É uma análise desse tipo que se propõe realizar neste capítulo, com relação ao Neoconstitucionalismo.

Pode-se dizer, em resumo, tratar-se de um esforço para responder à questão sobre como decidem os juízes neoconstitucionalistas, embora o propósito global da Tese seja exatamente analisar se essa concepção neoconstitucional é consistente e moralmente atrativa. A estratégia é identificar, a partir da análise feita nos capítulos anteriores, os valores atribuídos à prática jurídica pelos autores neoconstitucionalistas e o modo como eles ponderam as dimensões da adequação e da justificação. Com efeito, a inspiração, o enquadramento teórico e as teses defendidas por seus adeptos fornecem a matéria-prima necessária a uma análise crítica do Neoconstitucionalismo como uma teoria do Direito, como se pretende fazer neste capítulo.

Para tanto, serão abordados os seguintes itens: i) identificação do balanço entre as dimensões de adequação e justificação; ii) análise dos valores subjacentes a esse balanço a partir das espécies normativas valorizadas; iii) reflexão sobre a dimensão normativa dada às normas de direitos fundamentais, com ênfase nas normas programáticas; iv) métodos utilizados para resolução dos conflitos; v) a similitude do Neoconstitucionalismo ao pragmatismo jurídico. 


\section{2 - Permanência e mudança no Neoconstitucionalismo}

Como visto, a adequação e a justificação são denominações dadas por Dworkin para as duas dimensões distintas da interpretação jurídica que por vezes caminham em direções opostas: enquanto a adequação impõe que as novas decisões se encaixem no material jurídico existente, a justificação incita a revisão desses compromissos no afã de ajustá-los aos valores que legitimam a prática jurídica na visão do intérprete. Em casos extremos, nos quais o rompimento com o passado institucional se mostra como a única alternativa justa, há uma tensão entre permanência e mudança que deve ser equalizado por uma teoria jurídica, explicando os requisitos e as condições para que essa mutação ocorra. Nesse sentido, explica o autor norte-americano:

Identificar as proposições jurídicas verdadeiras é uma questão de interpretar de maneira construtiva o material jurídico; essa interpretação construtiva aspira a se adequar e a justificar esse material. Eu avisei que "adequação" e "justificação" eram nomes provisoriamente dados às duas dimensões da interpretação e que um refinamento posterior iria requerer uma análise mais cuidadosa de outros valores políticos que levariam a uma melhor compreensão dessas dimensões, de maneira que seria possível visualizar, por exemplo, como integrar ambas as dimensões em um juízo global de superioridade interpretativa quando elas puxam em direções opostas. Os conceitos políticos chaves que devem ser explorados dessa maneira parecem-me ser o da equidade procedimental, que é o nervo da dimensão da adequação, e o da justiça substantiva, que é o nervo da justificação política ${ }^{1}$.

A dimensão da adequação, portanto, indica o grau de respeito por parte do intérprete para com os compromissos institucionais assumidos pelos membros da comunidade no passado. Trata-se de uma avaliação sobre a legitimidade dos procedimentos utilizados para o estabelecimento das normas jurídicas em vigor. Essa análise envolve uma apreciação de duas facetas do princípio da igualdade. A primeira refere-se à igualdade de participação na formação da vontade política: quanto maior for o apreço do intérprete pelo procedimento democrático, mais complicado será para ele declarar a inconstitucionalidade de uma lei ou afastar a sua aplicação no caso concreto. Se o magistrado tiver consciência de que sua discordância com as razões adotadas em determinada cláusula legal significa que há um desacordo na sociedade sobre o tema e que a norma apenas reflete o posicionamento adotado pela maioria política em um procedimento considerado legítimo, então, por uma questão de

\footnotetext{
${ }^{1}$ Tradução livre de DWORKIN, 2006, p. 171.
} 
igualdade política, ele tenderá a aplicar tal dispositivo ${ }^{2}$. Se, noutro giro, o juiz sentir-se desconfortável com os resultados do processo político - entendendo-os como ilegítimos logo terá maior facilidade de adotar as suas próprias razões, afastando as da norma.

A segunda faceta do princípio da igualdade diz respeito à autoridade dos precedentes. A observância dos compromissos estabelecidos pelas decisões judiciais passadas possui um significado moral: implica tratamento isonômico entre os jurisdicionados, que poderão guiar suas condutas com base nos precedentes. O tratamento igualitário aos casos idênticos é um princípio moral que exerce força atrativa para a dimensão da adequação ${ }^{3}$. Assim, uma mudança de orientação jurisprudencial também envolve uma análise entre as dimensões de adequação e de justificação, em que o intérprete deverá sopesar os valores da segurança jurídica, da eficiência e da igualdade de tratamento com os valores substantivos perseguidos na decisão propriamente dita. Obviamente, o peso dado a cada uma das dimensões desencadeará soluções distintas.

Já a dimensão da justificação reflete os valores que justificam a prática jurídica como um todo. O que legitima o uso da força estatal por parte dos juízes? O que torna a organização da vida em sociedade por meio de um ordenamento normativo um ideal atraente? A resposta a essas perguntas acaba determinando a concepção de cada intérprete. Um utilitarista, por exemplo, vai concluir que o que justifica a prática jurídica é a maximização da felicidade ou da riqueza, o que significa dizer que os juízes estariam autorizados a dar um maior peso à dimensão da justificação do que à da adequação, sempre que a nova decisão aumente o nível geral de satisfação ou de riqueza. Um positivista, por outro lado, enfatiza os valores da segurança e da previsibilidade ao extremo, de maneira que somente nos casos em que a nova orientação promova mais segurança que a reafirmação da orientação antiga é que será possível romper com o passado institucional ${ }^{4}$. A versão jurídica atualmente mais difundida

\footnotetext{
${ }^{2}$ Em uma decisão bastante polêmica tomada pelo Tribunal de Recursos de São Francisco - Califórnia/EUA, a juíza Margaret McKeown concluiu que o governo norte-americano pode realizar escutas telefônicas independentemente de autorização judicial. Ao justificar sua decisão, a magistrada deixou claro, em seu voto, que estava adotando uma postura embasada no tipo de raciocínio até aqui desenvolvido: "De acordo com a estrutura jurídica, pode-se mover uma ação judicial por danos contra os Estados Unidos, pelo uso das informações coletadas, mas não processar o governo pela coleta das informações. Apesar de tal estrutura parecer anômala e mesmo injusta, o julgamento da política cabe ao Congresso e não aos tribunais". (MELO, 2012)

${ }^{3}$ Dworkin (2004, p. 15-16) explica esse ponto da seguinte forma: "Another process value, or another value that at least belongs under the general category of it rather than substantive justification, is the old idea of treating like cases alike. The idea is central to the question, 'When does a particular principle or proposal sufficiently fit with other principles so as to allow us to say the community has remained true to what it has done to some people in the past, has committed itself to a principle in virtue of the general equitable idea of treating like cases alike?"

${ }^{4}$ O positivismo é identificado com o valor da eficiência por Dworkin. Já a sua teoria é identificada com o valor da integridade, cujo conteúdo é formado por uma rede coerente princípios morais que justifica as instituições
} 
justifica a prática jurídica na proteção da dignidade humana. Nesse contexto, os juízes poderão superar os compromissos anteriormente firmados sempre quando houver violação a um direito fundamental. A extensão que se dá ao conceito de direito fundamental, entretanto, é o que dita as diferentes concepções jurídicas ${ }^{5}$.

Qual o balanço dado às duas dimensões pelos neoconstitucionalistas? Como se viu no capítulo 1, o modelo de atuação judicial que serve de inspiração aos adeptos dessa corrente doutrinária é aquele estabelecido no caso Brown v. Board of Education, em que houve o rompimento de uma estrutura social racista por meio de uma decisão judicial que modificou a própria compreensão do compromisso constitucional norte-americano. Fez-se, pela via judicial, uma revolução que provavelmente não seria levada a cabo pelo processo político ordinário. O Neoconstitucionalismo, assim, nasce de uma postura essencialmente cética quanto ao processo democrático. Há um inequívoco desconforto com relação à capacidade emancipatória do Poder Legislativo por parte dessa concepção jurídica. Não por outro motivo Barroso (2007a, p. 248) afirma que "o déficit democrático do Judiciário, decorrente da dificuldade contramajoritária, não é necessariamente maior que o do Legislativo, cuja composição pode estar afetada por disfunções diversas, dentre as quais o uso da máquina administrativa, o abuso do poder econômico, a manipulação dos meios de comunicação". É nessa mesma direção que Eduardo Moreira entende que, no Neoconstitucionalismo, ao contrário do constitucionalismo tradicional, a proteção dos direitos fundamentais é transferida do Legislativo para o Judiciário. A tese da vedação ao retrocesso por ele defendida também deixa subentendida a desconfiança com relação aos resultados do processo político.

Além disso, todos os neoconstitucionalistas acreditam na transformação da sociedade por meio da interpretação constitucional, o que significa dizer que eles apostam suas fichas na reforma das injustiças existentes no material jurídico, seja declarando a inconstitucionalidade das normas ou na revogação de precedentes, focando suas atenções especialmente para a dimensão da justificação. De fato, todos os temas abordados pelo Neoconstitucionalismo apontam no sentido de expandir as competências do Poder Judiciários e de conferir maior

políticas como um todo. Trata-se, portanto, de uma teoria holística. Ou seja, o Direito está inserido dentro de um contexto maior da moralidade política, baseada na ideia de igual consideração e respeito entre os membros da comunidade. Sua tentativa de unificação de todas as suas teses em um único pensamento foi traduzido em seu último livro Justice for Hedgehogs. (DWORKIN, 2011)

5 A fórmula de Radbruch, muito difundida nos meios acadêmicos nacionais, é um exemplo claro em que há uma ponderação entre as duas dimensões, em que a dignidade humana, em casos extremos, reclama ignorar a adequação. Segundo o autor, "o conflito entre justiça e certeza jurídica pode ser bem resolvido do seguinte modo: o direito positivo, assegurado pela legislação e pelo poder, tem prioridade mesmo quando o seu conteúdo é injusto e não beneficiar as pessoas, a menos que o conflito entre a lei e a justiça chegue a um grau intolerável em que a lei, como uma "lei defeituosa", deva clamar por justiça". (tradução livre de RADBRUCH, 2006, p. 7) 
criatividade para os juízes decidirem os casos. As teses da sobreinterpretação da Constituição e da derrotabilidade das regras, defendidas por Eduardo Ribeiro Moreira, do efeito expansivo das normas constitucionais e da nova interpretação constitucional, apoiada por Luís Roberto Barroso, da irradiação dos direitos fundamentais como impulsos emancipatórios, na linguagem de Antônio Cavalcanti Maia, caminham no sentido de dar aos juízes o status de guardiães das promessas civilizatórias, nos dizeres de Daniel Sarmento.

Os elementos que o Neoconstitucionalismo compartilha do realismo jurídico (capítulo 1) também apontam para uma desvalorização da dimensão da adequação. $O$ ceticismo com relação à racionalidade firmada nos precedentes e nas leis, aliado à ideia de reforma da sociedade por meio do Direito a partir de uma interpretação focada basicamente nos resultados, levam inexoravelmente a uma interpretação da prática jurídica em que se ignora a força dos compromissos institucionais estabelecidos no passado. Busca-se estabelecer novos paradigmas a cada decisão judicial. No caso do Neoconstitucionalismo, isso parece evidente quando os autores afirmam que todos os casos são, na verdade, casos constitucionais, aplicando os princípios constitucionais diretamente, inclusive nas relações entre particulares, o que exige um esforço hermenêutico gigantesco por parte dos juízes ao decidirem os casos concretos. Em outras palavras, a validade das normas jurídicas está em constante questionamento em face da Constituição.

O Neoconstitucionalismo, portanto, apresenta uma visão eminentemente prospectiva do fenômeno jurídico: a interpretação legal se revela como o instrumento de transformação social. O balanço entre as duas dimensões da interpretação jurídica nessa concepção jurídica parece pender em muito para o lado da justificação, visto que a adequação sugere um olhar retrospectivo, em que as razões do passado limitam as opções do presente, o que praticamente não ocorre para essa doutrina. Essa conclusão é corroborada pela fixação de seus membros por princípios em detrimento das regras, conforme se verifica a seguir.

\section{3 - Regras $x$ princípios}

Os neoconstitucionalistas possuem clara preferência por uma espécie normativa específica: os princípios. De fato, Eduardo Ribeiro Moreira (2008, p. 38) resume essa doutrina como "ênfase nos princípios e nos direitos fundamentais, diminuindo a força do tudo ou nada das regras $"$. Luís Roberto Barroso (2007, p. 214), ao discorrer sobre a nova interpretação

\footnotetext{
${ }^{6}$ Eduardo Ribeiro Moreira (2007, p. 94) afirma expressamente que as regras passam a ter menos importância no Neoconstitucionalismo, já que "agora normatizados, axiológicos e positivados, os princípios são o coração
} 
constitucional, também afirma que "o reconhecimento de normatividade aos princípios e sua distinção qualitativa em relação às regras é um dos símbolos do pós-positivismo". No mesmo sentido é a lição de Daniel Sarmento (2009, p. 127), para quem "nessa nova fase, a doutrina brasileira passa a enfatizar o caráter normativo e a importância dos princípios constitucionais, e a estudar as peculiaridades da sua aplicação". Por fim, Antônio Cavalcanti Maia (2008, p. 215) afirma que o Neoconstitucionalismo nasce da "necessidade do desenvolvimento de um sistema de categorias identificatório da nova realidade, (...) dado o fenômeno da principialização dos sistemas jurídicos e da correlata constitucionalização do direito".

Essa ênfase dada aos princípios tem a ver com o modelo Brown endossado como padrão judicial pelo Neoconstitucionalismo. Como se viu, no caso Brown v. Board of Education, que pôs fim à segregação racial nos Estados Unidos, a Corte Warren afastou o entendimento de que as cláusulas constitucionais deveriam ser compreendidas de acordo com o compromisso firmado em sua ratificação, interpretando a décima quarta emenda constitucional como um princípio abstrato à igualdade, o que possibilitou uma leitura moral da Carta Magna e resultou em uma decisão profética, nos dizeres de Bruce Ackerman. A décima quarta emenda, portanto, foi interpretada como um princípio de moralidade política que estabelece um parâmetro normativo geral, autorizando a reforma das normas jurídicas contrárias aos valores nele identificados. Essa concepção abstrata dos princípios que inspira o Neoconstitucionalismo.

A preferência por princípios em detrimento das regras revela outro indício de que a dimensão da adequação é colocada em segundo plano pelo Neoconstitucionalismo. Partindo da classificação elaborada por Humberto Ávila, é fácil perceber que essa escolha normativa tem como efeito realçar os elementos substantivos da decisão, ao mesmo tempo em que diminui a importância do passado institucional para a solução dos casos presentes. Eis a definição de regra para Humberto Ávila:

As regras são normas imediatamente descritivas, primariamente retrospectivas e com pretensão de decidibilidade e abrangência, para cuja aplicação se exige a avaliação de correspondência, sempre centrada na finalidade que lhes dá suporte e nos princípios que lhe são axiologicamente sobrejacentes, entre a construção conceitual da descrição normativa e a construção conceitual dos fatos ${ }^{7}$.

das Constituições contemporâneas". Nesse sentido, ele (2007, p. 96) afirma: "Os princípios têm incidência projetiva e aberta à interpretação. Seu peso, sua importância, é muito maior do que da regra".

7 ÁVILA, 2008, p. 78. 
De acordo com o referido autor, as regras, além de descreverem com antecedência os fatos que são relevantes, possuem pretensão de decidibilidade, o que significa que o legislador ponderou as razões para a solução dos dilemas apresentados nas situações antevistas pela norma e decidiu os efeitos jurídicos para aqueles fatos. A forma concreta como as pessoas devem agir para produzir ou evitar tais efeitos fica previamente estipulada pela regra, forçando o agente a levar em consideração as razões normativas na definição de seu agir prático.

A obediência aos precedentes assume a mesma feição. Ocorrida situação análoga àquela já decidida pelas cortes, deve-se seguir o mesmo padrão de conduta nos casos futuros. O que está por trás do estabelecimento de regras a serem seguidas é a busca pela realização de determinada finalidade que o legislador ou os juízes, depois de ponderadas as razões, consideraram importantes. Como as regras já prescrevem as consequências jurídicas que devem ser imputadas caso os eventos descritos no comando normativo ocorram no mundo dos fatos, o intérprete não precisa escolher quais comportamentos são exigidos, bastando obedecer à norma, desonerando-o de um maior esforço hermenêutico para justificar a decisão tomada.

Os princípios, por outro lado, são assim conceituados:

Os princípios são normas imediatamente finalísticas, primariamente prospectivas e com pretensão de complementariedade e de parcialidade, para cuja aplicação demandam uma avaliação da correlação entre o estado de coisas a ser promovido e os efeitos decorrentes da conduta havida como necessária à sua promoção ${ }^{8}$.

Ao contrário das regras, que estabelecem de antemão o que deve ser feito, os princípios exigem que o intérprete faça uma análise de correlação entre os efeitos das condutas a serem adotadas e a realização do estado de coisas exigido. Ou seja, cabe ao intérprete decidir como as pessoas devem agir para promover os valores subjacentes aos princípios. Não há consequências imediatas. Elas são construídas pelo intérprete. Por esse motivo Humberto Ávila (2008, p. 76) afirma que "as regras assumem caráter retrospectivo (past-regarding), na medida em que descrevem uma situação de fato conhecida pelo legislador; ao contrário dos princípios, que possuem caráter prospectivo (future-regarding), já que determinam um estado de coisas a ser construído".

Enquanto as regras têm a pretensão de gerar uma solução específica para o conflito entre razões no caso concreto, os princípios visam a contribuir, ao lado de outras razões, para

\footnotetext{
${ }^{8}$ ÁVILA, 2008, p. 180.
} 
a tomada de decisão. Percebe-se que o intérprete, ao se basear exclusivamente em princípios para decidir um caso, terá muito mais liberdade de escolha, já que não estará adstrito às condutas previamente descritas nem vinculado à adoção de determinado resultado. Sua função é essencialmente reconduzir sua conclusão ao ordenamento jurídico, o que já torna legítima sua atuação. Em ordenamentos jurídicos como o nosso, em que há inúmeros princípios constitucionais imbuídos de valores aparentemente contraditórios, ou seja, que visam a fins conflitantes, a concretização da Carta Magna fica eminentemente a cargo dos magistrados. Isso se torna mais dramático quando se percebe que "a constitucionalização louvada $e$ defendida pelo Neoconstitucionalismo é aquela que parte de uma interpretação extensiva e irradiante dos direitos fundamentais e dos princípios mais importantes da ordem constitucional" 9 . As doutrinas da força normativa da Constituição, da eficácia horizontal dos direitos fundamentais e da constitucionalização do Direito induzem o intérprete a utilizar os princípios constitucionais em todos os casos jurídicos, o que consequentemente leva a uma atuação mais criativa e livre por parte dos juízes.

Outro ponto intimamente relacionado à preferência por princípios é a valorização das denominadas cláusulas gerais e dos conceitos jurídicos indeterminados por parte dos neoconstitucionalistas. Eduardo Moreira, ao criticar o novo Código Civil, afirma que se trata de um documento já antigo por possuir poucas normas abertas. Antonio Cavalcanti Maia também afirma que a nova dogmática trabalha essencialmente com standards ${ }^{10}$. Essas espécies de normas também fornecem espaços livres para a construção judicial do significado normativo por parte do intérprete, seja na descrição de sua hipótese de incidência ou na prescrição de suas consequências, o que o aproxima dos princípios. Em todos esses casos, deixam-se aspectos não resolvidos para que se faça um juízo a posteriori sobre qual atitude é a mais apropriada para os fins almejados pela norma. Ou seja, na escolha de um modelo de norma, pondera-se se o mais importante é que haja previsibilidade, resolvendo-se o conflito entre as razões de maneira prévia, como normalmente ocorre no direito penal e no tributário,

\footnotetext{
9 SARMENTO, 2009, p. 143.

${ }^{10}$ Cass Sunstein (1995, p. 964-965) afirma que, em se tratando de espécies de normas jurídicas, os standards se contrapõem às regras, sendo espécies de cláusulas legais que não estão completamente especificadas. Assim, o conteúdo dos standards depende de seu aplicação por parte dos intérpretes, que analisarão as circunstâncias do caso concreto para definir sobre a sua incidência nos fatos ocorridos. Um exemplo de regra em contraposição a um standard seria uma regra que estabelece a velocidade máxima de uma via em $80 \mathrm{~km}$ e um standard que afirma que as pessoas não podem dirigir em velocidade acima do razoável. Para uma discussão sobre a possibilidade de uma pessoa efetivamente se guiar por normas vagas, cf. WALDRON, 2010b (afirmando que pessoas racionais têm plena capacidade de se guiarem por standards, mas que o problema se verifica na aplicação futura da norma, já que nem todo mundo chegará a conclusões semelhantes sobre o que significa dirigir sem exceder o limite razoável, por exemplo).
} 
ou se é mais adequado deixar para se decidir quais razões devem prevalecer no momento da interpretação judicial.

O Neoconstitucionalismo, ao identificar princípios e regras abertas como casos centrais da prática jurídica, faz uma opção inequívoca pela dimensão da justificação. Os autores dessa doutrina jurídica buscam se esquivar de constrangimentos institucionais para adotar um modelo voltado para a substância das decisões judiciais, seja por uma atuação mais agressiva da jurisdição constitucional ou pela positivação de normas que exigem uma maior participação do intérprete em sua aplicação. Não se está defendendo que as regras sejam opções superiores aos princípios: todo ordenamento jurídico é essencialmente híbrido e toda norma deve ser cuidadosamente cunhada para melhor servir à sua finalidade subjacente. $\mathrm{O}$ Neoconstitucionalismo, entretanto, parece defender que as questões sejam preferencialmente decididas pela via judicial, minimizando a importância dos procedimentos políticos de tomada de decisão. Essa característica ficará mais evidente na abordagem do próximo item.

\section{4 - Direitos fundamentais: argumentos de princípio e de política no Neoconstitucionalismo}

Como já visto no capítulo 1 , o controle de constitucionalidade é o mecanismo por excelência pelo qual se torna possível uma mudança estrutural da sociedade pelo Direito. De fato, a interpretação constitucional transfigura-se num potente instrumento de revisão dos compromissos anteriormente firmados pela sociedade, independentemente da existência de engajamento político de seus membros para tanto. Nesse ponto, revela-se importante verificar que o judicial review apresenta-se como uma das pontes da dimensão da adequação para a da justificação, permitindo a reforma do material jurídico existente a fim de adequá-lo aos requisitos de justiça substantiva. Dentre as várias justificativas que autorizam essa intervenção judicial, a proteção aos direitos fundamentais é a que melhor expressa a teoria neoconstitucional e a maioria das concepções jurídicas atualmente difundidas.

Ocorre que o conceito alargado do que seja direito fundamental e, consequentemente, do parâmetro de controle para o Neoconstitucionalismo, é o que marca distintivamente essa corrente doutrinária. Todas as normas constitucionais, inclusive aquelas que apenas proclamam objetivos políticos a serem alcançados - e não direitos propriamente ditos passam a irradiar efeitos para fins de concretização judicial das promessas civilizatórias contidas na Carta Magna. Veja, a esse propósito, o alcance conferido ao tema por Eduardo Ribeiro Moreira: 
Os direitos fundamentais são as diretrizes da ingerência judicial nas intensidades aqui classificadas como médias e fortes - estas envolvem não somente onde gastar, mas em que, quanto e como gastar. Por tudo isso, o controle judicial das políticas públicas fica bem adaptado ao Neoconstitucionalismo, já que se baseia em duas espécies de normas constitucionais - políticas e direitos fundamentais - e dirige as metas políticas dos governantes, corrige as escolhas e salvaguarda a Constituição ${ }^{11}$.

Luís Roberto Barroso comunga de entendimento semelhante ao afirmar que "os valores, os fins públicos e os comportamentos contemplados nos princípios e regras da Constituição passam a condicionar a validade e o sentido de todas as normas do direito infraconstitucional" 12 . Também Daniel Sarmento deixa claro que, no seu entender, as "metas e diretrizes, estabelecidas em regra através de normas programáticas, não devem ser vistas como meras proclamações retóricas. Elas são normas jurídicas, que de alguma maneira vinculam os poderes políticos" ${ }^{13}$. A utilização de objetivos políticos como parâmetro de controle é justificada, nos dizeres de Antônio Cavalcanti Maia, por ser "mais adequada às possibilidades de uma utilização progressista, isto é, democrático-igualitária, marcada por um viés redistributivo, já que busca mecanismos capazes de efetivar os direitos fundamentais $" 14$. Em síntese, para a doutrina neoconstitucional, a atividade jurisdicional também deve se imiscuir na análise do mérito das políticas públicas adotadas tendo como fito a melhor forma de redistribuição de renda como meio de concretização dos direitos fundamentais, utilizando-se, para tanto, das normas programáticas que ganham eficácia normativa plena nesse "novo paradigma do Direito".

Contudo, ao adotar uma concepção em que os objetivos e fins públicos também são levados em consideração pelos juízes para superar a dimensão da adequação, fornece-se uma gama muito variada de argumentos que podem ser invocados para ignorar os constrangimentos institucionais existentes. Na perspectiva neoconstitucional, o Poder Judiciário fica autorizado a discutir o mérito das escolhas dos outros poderes tendo como parâmetro normas que estabelecem objetivos políticos a serem alcançados em longo prazo pelo Estado, e não direitos fundamentais propriamente ditos. Os juízes passam a analisar quais escolhas são mais adequadas para se atingir determinadas metas, optando por uma dentre as diversas estratégias existentes. Assim, ao invés de se verem constrangidos pelos

\footnotetext{
${ }^{11}$ MOREIRA, 2009, p. 144.

12 BARROSO, 2007, p. 217-218.

13 SARMENTO, 2007, p. 124. Ainda, segundo o autor, a Constituição estabeleceu "objetivos e diretrizes para a comunidade política, correlacionados a um amplo e generoso projeto de transformação da sociedade brasileira, no sentido da promoção da justiça social, da liberdade real e da igualdade substantiva (...) que vinculam [juridicamente] os poderes políticos".

14 MAIA, 2009, p. 214.
} 
compromissos políticos anteriormente firmados, os magistrados passam a eleger os próprios compromissos, orientando-se não por um juízo deontológico, mas teleológico ${ }^{15}$. Uma comparação entre o alcance das propostas do Neoconstitucionalismo e da teoria de Ronald Dworkin é elucidativa com relação aos efeitos dessa adoção de postura.

Como dito no tópico anterior, Dworkin considera que todas as proposições jurídicas são interpretações construtivas do material jurídico, atividade em que o intérprete impõe valores à prática social existente - justificando-a do ponto de vista da moralidade política que deverão ser observados na solução dos casos futuros. Essa intepretação impõe a adoção de determinados padrões de conduta para a concretização desses valores, que são os princípios jurídicos resgatados na história institucional da comunidade. O filósofo americano, então, lança mão da ideia de três ideias fundamentais para a compreensão de sua teoria: a comunidade de princípios, o romance em cadeias e o juiz Hércules.

A comunidade de princípios (1986, p. 211-216) pressupõe que, em uma sociedade justa, seus membros entendem que as regras explícitas criadas nas decisões políticas do passado pressupõem a adoção de princípios morais implícitos que se amoldam a novas circunstâncias. É isso que Dworkin denomina de integridade: a comunidade deve ser vista como um ente personificado que age com retidão e coerência. Assim, as normas jurídicas reconhecidas fornecem razões para a resolução de outros casos para além de suas hipóteses expressas, sem a necessidade de um detalhamento da legislação ou da jurisprudência para cada um dos pontos de conflito. A prática política transforma-se em uma arena em que os membros da sociedade travam um debate moral sobre quais princípios devem ser adotados em

\footnotetext{
${ }^{15}$ Habermas (2003, p. 316) explica que "princípios ou normas mais elevadas, em cuja luz outras normas podem ser justificadas, possuem um sentido deontológico, ao passo que os valores têm um sentido teleológico. Normas válidas obrigam os destinatários, sem exceção e em igual medida, a um comportamento que preenche expectativas generalizadas, ao passo que valores devem ser entendidos como preferências compartilhadas intersubjetivamente. Valores expressam preferências tidas como dignas de serem desejadas em determinadas coletividades, podendo ser adquiridas ou realizadas através de um agir direcionado a um fim. Normas surgem com uma pretensão de validade binária, podendo ser válidas ou inválidas; em relação a proposições normativas, como no caso de proposições assertóricas, nós só podemos tomar posição dizendo 'sim' ou 'não', ou abster-se do juízo. Os valores, ao contrário, determinam relações de preferência, as quais significam que determinados bens são mais atrativos do que outros, por isso, nosso assentimento a proposições valorativas podem ser maior ou menor. A validade deontológica de normas tem o sentido absoluto de uma obrigação incondicional e universal: ao que deve ser pretende ser igualmente bom para todos. Ao passo que a atratividade de valores tem o sentido relativo de uma apreciação de bens, adotada e exercitada no âmbito de formas de vida ou de uma cultura: decisões valorativas mais graves ou preferências de uma ordem superior exprimem aquilo que, visto no todo, é bom para nós (ou para mim). Normas diferentes não podem contradizer umas às outras, caso pretendam validade no mesmo círculo de destinatários; devem estar inseridas num contexto coerente, isto é, formar um sistema. Enquanto valores distintos concorrem para obter a primazia; na medida em que encontram reconhecimento intersubjetivo no âmbito de uma cultura ou forma de vida, eles formam configurações flexíveis e repletas de tensões".
} 
nome da coletividade. As decisões institucionais são vistas como compromissos de princípios que não se esgotam em seus termos canonizados.

O romance em cadeia (1986, p. 228-232) pressupõe que os juízes, ao decidirem os casos judiciais, falam em nome da comunidade personificada, de maneira que eles devem agir de maneira coerente com o passado institucional da comunidade, honrando os compromissos anteriormente firmados. Na metáfora do romance em cadeia, os juízes escrevem a cada decisão um novo capítulo de uma história que tem a pretensão de ser atraente. Assim, o intérprete se encontra constrangido pelo que foi escrito nos capítulos anteriores, ao passo em que deve desenvolver o romance de maneira a torná-lo digno de valor. Há, portanto, a necessidade de manutenção de coerência com o passado institucional e o dever de construção de uma decisão que seja a que melhor exprima os compromissos morais assumidos pela comunidade, o que, no campo do Direito, representa o reconhecimento e o respeito aos direitos.

Essa necessidade de integridade nas decisões judiciais exige do magistrado uma análise aprofundada da história institucional da comunidade e uma interpretação moral aguçada para estabelecer uma rede coerente de princípios que exprimam os valores que tornam a prática jurídica justificada. Para a realização de tal tarefa, Dworkin (1986, p. 239250) cria a figura do juiz Hércules, que, por possuir capacidade e paciência sobre-humanas, consegue, a partir dos princípios compartilhados pela comunidade, escrever capítulos coerentes e justificados a cada decisão judicial. Essa atitude hercúlea é assim descrita por Flávio Quinaud Pedron:

Dworkin imagina um magistrado com capacidades e paciência sobre-humanas, competente para, de maneira criteriosa e metódica, selecionar as hipóteses de interpretação dos casos concretos a partir do filtro da integridade. Assim, em diálogos com as partes daqueles processos, ele deverá interpretar a história institucional como um movimento constante e partindo de uma análise completa e criteriosa da Constituição, da legislação e dos precedentes, para identificar nestes a leitura feita pela própria sociedade dos princípios jurídicos aplicáveis aos casos ${ }^{16}$.

Somente nas hipóteses em que a continuação do mesmo padrão institucional contraria frontalmente os requisitos de justiça substantiva é que os magistrados estão autorizados a modificar o enredo ${ }^{17}$. Nessas ocasiões excepcionais, a dimensão da justificação se sobrepõe à

\footnotetext{
${ }^{16}$ PEDRON, 2005, p. 74.

${ }^{17}$ Nesse sentido, explica Dworkin (1986, p. 248): “But [Hercules] must set these reasons against his more substantive political convictions about the relative moral value of the two interpretations, and if he believes
} 
da adequação reformando parte da prática jurídica, a fim de que ela se adapte aos valores que apresentam o Direito em sua melhor versão. Para Dworkin, portanto, a transição entre as dimensões da adequação e da justificação se dá por meio dos princípios jurídicos. Verificando que uma série de precedentes ou que um determinado ato normativo encontra-se em conflito com os princípios assumidos pela comunidade personificada, o magistrado deve corrigi-lo para manter a coerência do sistema. Ou seja, uma guinada jurisprudencial que altere a interpretação sobre determinado tema somente se mostra legítima se os princípios que a subsidiam melhor justificam a prática jurídica do que as justificativas subjacentes ao posicionamento superado. Mas esse trabalho construtivo de Dworkin de inserir o debate jurídico dentro de um contexto concreto faz com que os princípios por ele reconhecidos sejam históricos e morais.

Cumpre salientar que, para Dworkin (2002, p. 129), “os argumentos de princípio justificam uma decisão política, mostrando que a decisão respeita ou garante um direito a um indivíduo ou de um grupo". Os princípios, portanto, apresentam-se como as justificativas morais dos direitos fundamentais, servindo como trunfos contra a decisão da maioria. Nesse sentido, Dworkin entende que as cláusulas constitucionais mais relevantes estabelecem princípios que impõem limites à atividade governamental, fazendo com que o intérprete realize uma leitura moral da Constituição para identificar os direitos dos cidadãos. Na visão do autor, para que haja a declaração de inconstitucionalidade de uma lei, a revogação de um precedente ou a anulação de um ato governamental torna-se necessária a violação de um princípio, pois não é permitido a qualquer órgão ignorar os direitos dos membros da comunidade.

Se, por um lado, Dworkin entende justificado um rompimento factual dos compromissos estabelecidos caso haja uma unidade de princípio moralmente atrativa por trás dessa mudança, por outro considera ilegítima a atitude do intérprete de abandonar o histórico institucional com base em argumentos de política. De acordo com o autor, "os argumentos de política justificam uma decisão política, mostrando que a decisão fomenta ou protege algum objetivo da comunidade como um todo" ${ }^{18}$. Para ele, as decisões que envolvem a consideração de diferentes interesses na promoção de determinados fins, fazendo opções estratégicas entre as alternativas políticas existentes, devem ser tomadas por meio do processo político majoritário. Isso porque, ao se eleger determinadas finalidades e objetivos como prioritárias

\footnotetext{
that [a new] interpretation is much superior from that perspective, he will think he makes the legal record better overall by selecting it even at the cost of the more procedural values".

18 DWORKIN, 2002, p. 129.
} 
no campo político, faz-se uma escolha que desagrada pessoas ou grupos que não se veem representados pela medida. Enquanto os princípios têm pretensão de universalidade, as políticas são sempre parciais, simbolizando uma compreensão particular sobre o que seja uma vida boa.

Em uma sociedade notadamente marcada pela pluralidade de pontos de vista, a adoção de uma opção política específica por parte de juízes em nome da sociedade implica necessariamente violação ao princípio da igualdade de participação. Não por outro motivo, na visão de Dworkin os juízes somente podem invocar princípios que moralmente justifiquem os compromissos já estabelecidos pela sociedade para decidir os casos judiciais ${ }^{19}$. Qualquer outra razão não jurídica que motive uma decisão judicial torna-a ilegítima. Além disso, as escolhas realizadas a partir de argumento de política muitas vezes violam direitos propriamente ditos, o que, como visto acima, autoriza a intervenção judicial para bloquear o agir governamental. Seria um contrassenso autorizar que o órgão incumbido de proteger tais direitos realizasse juízo político ao tomar suas decisões. A promoção do bem-estar da comunidade é um problema que deve ser resolvido pelos agentes políticos eleitos para tanto que a definem de maneira geral, não por juízes que decidem casos particulares.

Percebe-se, pois, que, para Dworkin, argumentos de princípio não se confundem com argumentos que simplesmente invocam um dos princípios estabelecidos na nossa Constituição. Pelo contrário, nossa Carta Magna positivou várias cláusulas que não obstante serem denominadas como princípio pela doutrina em razão de sua abstração, na verdade desencadeiam argumentos de política. O simples fato de o art. 37 da lei fundamental preceituar que a Administração Pública obedecerá ao princípio da eficiência não tem o condão de transformar um argumento de política que o mencione em um argumento de princípio ${ }^{20}$. Essa confusão terminológica talvez explique o motivo pelo qual a teoria de Dworkin é tantas vezes mencionada em nossa doutrina em contextos equivocados. Os princípios, no pensamento dworkiano, são extraídos a partir de uma reconstrução dos valores morais que animam a prática jurídica, não sendo possível transformar uma razão teleológica em princípio apenas por designá-la como tal.

\footnotetext{
${ }^{19}$ Flávio Quinaud Pedron distingue princípio de política no pensamento de Dworkin da seguinte forma: “o princípio é aquele padrão que contém uma exigência de justiça, equidade, devido processo legal ou qualquer outra dimensão de moralidade. Por sua vez, o padrão denominado 'política' busca estabelecer um objetivo a ser alcançado, que, geralmente, consiste na melhoria de algum aspecto econômico, político ou social de uma dada comunidade, buscando promover ou assegurar uma situação considerada desejada”.

${ }^{20}$ Brasil. Constituição Federal de1988. O art. 37, caput, assim preceitua: "A administração pública direta $e$ indireta de qualquer dos Poderes da União, dos Estados, do Distrito Federal e dos Municípios obedecerá aos princípios de legalidade, impessoalidade, moralidade, publicidade e eficiência e, também, ao seguinte".
} 
Partindo dessa distinção entre argumentos de princípio e argumentos de política, Dworkin faz uma classificação entre direitos jurídicos, que podem ser exigidos em um tribunal, e direitos políticos, que devem ser implementados pelos demais órgãos estatais ${ }^{21}$. Segundo o referido autor, uma interpretação construtiva da prática jurídica também inclui uma análise sobre princípios de alocação do poder político em um Estado coercitivo: decisões que envolvam uma análise de oportunidade estratégica sobre investimentos de recursos públicos e escolhas de metas e objetivos devem ser tomadas pelos órgãos destinados à administração da vida em coletividade. O Poder Judiciário somente deve entrar em ação quando os direitos políticos são transformados em direitos jurídicos através da edição de atos normativos que concretize determinado esquema de saúde ou ensino público, por exemplo, tornando exigíveis os compromissos assumidos pela comunidade personificada. Ou seja, deve-se esperar que a política pública seja determinada pelos órgãos políticos para que as promessas constitucionais que necessitem de escolhas políticas sejam exigíveis em tribunais:

Podemos dizer que nem todos os direitos que uma Constituição declara são direitos legais. Alguns, como aqueles referentes à política externa, ou aqueles concretizados de maneira muito mais eficiente por outros órgãos do governo, são mais bem tratados como direitos políticos, mas não jurídicos - isso é, como direitos não exigíveis por pessoas em ações jurídicas privadas. Outros, como o direito ao tratamento igualitário em um esquema de saúde pública já implementado pelo governo, são de fato direitos jurídicos ${ }^{22}$.

Nesse diapasão, para Dworkin, ao contrário do que defendem os neoconstitucionalistas, as normas programáticas e as políticas públicas estatuídas no texto constitucional não são exigíveis sem intermediação legislativa. Como consequência, não é possível transitar entre as dimensões da adequação e da justificação tendo por base fins políticos a serem alcançados. Somente princípios que reflitam direitos fundamentais exigíveis juridicamente exercem essa função. Argumentos de política, portanto, quedam-se excluídos do discurso jurídico, impedindo a reforma do material jurídico existente com base em considerações estratégicas.

\footnotetext{
${ }^{21}$ Dworkin (2011, p. 405-406) explica esse ponto da seguinte maneira: "Legal rights can sensibly be distinguished from other political rights only if that community has at least na embryonic version of the separation of powers Montesquieu described. It is then necessary to distinguish two classes of political rights and duties. Legislative rights are rights that the community's lawmaking powers be exercised in certain way: to create and administer a system of public education, for instance, and not to censor political speech. Legal rights are those that people are entitled to enforce on demand, without further legislative intervention, in adjudicative institutions that direct the executive power of sheriff or police".

${ }^{22}$ Tradução livre de DWORKIN, 2011, p. 412-413.
} 
O Neoconstitucionalismo propõe que os juízes adotem um viés redistributivo, nos dizeres de Antônio Cavalcanti Maia, favorecendo a utilização de argumentos políticos por parte do intérprete para modificação do status quo. Essa ênfase na transformação da sociedade por meio do Direito acaba por desfigurar a atividade judicial. Enquanto no esquema desenvolvido por Dworkin a modificação da história institucional se dá por meio de uma interpretação mais virtuosa dos princípios que embasam os compromissos institucionais já assumidos pela comunidade, o Neoconstitucionalismo permite que argumentos de política propulsionem uma remodelação das relações sociais, econômicas e políticas.

Essa concepção jurídica, entretanto, não se mostra moralmente atrativa. Em primeiro lugar, por desrespeitar os acordos intersubjetivamente firmados pela sociedade personificada por meio de decisões judiciais que carecem de legitimidade democrática. Como se verá nos capítulos seguintes, há uma moralidade intrínseca na dimensão da adequação consubstanciada no ideal político do Estado de Direito que é enfraquecido com esse uso instrumental da jurisdição constitucional. Em segundo lugar, por transformar o Poder Judiciário em potencial violador de direitos, ao invés de guardião destes. Explica-se: ao se adotar uma política pública de redistribuição de renda pela via judicial, está-se admitindo a relativização dos direitos de alguns membros da sociedade em favor de outros. A ponderação de valores, técnica interpretativa venerada pelos neoconstitucionalistas, revela bem as inconsistências do Neoconstitucionalismo.

\section{5 - Ponderação: o papel das razões jurídicas no Neoconstitucionalismo}

Tornou-se lugar-comum no discurso neoconstitucional afirmar que, em razão do caráter principiológico das constituições do pós-guerra, a ponderação passou a ser o método hermenêutico mais utilizado pelos intérpretes. Eduardo Moreira (2008, p. 95), por exemplo, afirma que "os princípios no Neoconstitucionalismo [...] têm fundamentação orientada pela pretensão de correção e a sua aplicação [...] dá-se mediante ponderação". No mesmo sentido, Antônio Cavalcanti Maia leciona:

Os métodos tradicionais de resolução de conflitos normativos não são mais suficientes. As decisões judiciais dependem de argumentos complexos, exigem decisões envolvendo princípios que vão além do uso do esquema lógico-dedutivo, e requerem, também, por parte do juiz, o uso da racionalidade teleológica. Assim, o constitucionalismo alicerçado em princípios e direitos parece exigir que os juízes, ao se depararem cada vez 
mais com "casos difíceis", se tornem filósofos (Dworkin) e, além disso, dominem complexas técnicas de ponderação de bens e valores ${ }^{23}$.

Daniel Sarmento (2009, p. 129) menciona a "valorização dos princípios, adoção de métodos ou estilos mais abertos e flexíveis da hermenêutica jurídica, com destaque para a ponderação" como características essenciais do Neoconstitucionalismo. Também Luís Roberto Barroso (2007, p. 215) afirma que, no Neoconstitucionalismo, "a existência de colisões de normas constitucionais, tanto as de princípios como as de direitos fundamentais, (...) leva à necessidade de ponderação" "24. Ademais, como visto acima, os neoconstitucionalistas, em virtude do princípio da força normativa da Constituição, entendem que, ao lado dos princípios que exprimem direitos, as normas programáticas, os bens e os valores expressos no texto constitucional também devem ser ponderados na solução de um litígio.

Para equacionar os conflitos entre razões antagônicas que animam as diversas normas constitucionais, a doutrina neoconstitucional apela para os princípios ${ }^{25}$ da razoabilidade ${ }^{26}$ e da proporcionalidade como critérios interpretativos. O raciocínio entabulado é que, em razão da inexistência de consequências jurídicas definidas nessas espécies normativas, a decisão judicial deve levar em consideração essas razões, por vezes contraditórias, para resolver a

${ }^{23}$ MAIA, 2008, p. 221.

${ }^{24}$ Barroso (2007, p. 215) completa o seu raciocínio: “Neste cenário, a ponderação de normas, bens ou valores é a técnica a ser utilizada pelo intérprete, por via da qual ele (i) fará concessóes recíprocas, procurando preservar o máximo possível de cada um dos interesses em disputa ou, no limite, (ii) procederá à escolha do direito que irá prevalecer, em concreto, por realizar mais adequadamente a vontade constitucional".

${ }^{25}$ A classificação da razoabilidade e da proporcionalidade como princípios não é compartilhada por todos. Virgílio Afonso da Silva (2002) defende que a proporcionalidade é uma regra. Humberto Ávila (2008), por outro lado, diferencia regras e princípios, que seriam normas aplicáveis, dos postulados normativos, que seriam normas que instituem os critérios de aplicação de outras normas situadas no plano do objeto da aplicação. Para Ávila, a ponderação, a razoabilidade e a proporcionalidade seriam postulados normativos não coincidentes. Na presente Tese, conforme se verá a seguir, a proporcionalidade será tratada como princípio, pois na doutrina neoconstitucional, em razão da amplitude dada às normas constitucionais conflitantes, tudo passa a ser questionável e a ser resolvido pelo balanceamento, de maneira que a razoabilidade e a proporcionalidade passam a ser os próprios parâmetros de controle.

${ }^{26} \mathrm{Na}$ doutrina, há autores que afirmam que os princípios da razoabilidade e da proporcionalidade seriam conceitos similares. Luís Roberto Barroso (2007, p. 15), por exemplo, afirma que "razoabilidade e proporcionalidade são conceitos próximos o suficiente para serem intercambiáveis, não havendo maior proveito metodológico ou prático na distinção". Outros, como Virgílio Afonso da Silva (2002, p. 45), negam veementemente tal semelhança: "Proporcionalidade e razoabilidade não são sinônimos. Enquanto aquela tem uma estrutura racionalmente definida, que traduz na análise de suas três sub-regras (adequação, necessidade e proporcionalidade em sentido estrito), esta ou é um dos vários topoi dos quais o STF se serve, ou simples análise de compatibilidade entre meios e fins". Para os fins dessa Tese a distinção é irrelevante, bastando enfatizar que ambas as metodologias visam balancear as normas de direitos fundamentais. 
questão constitucional posta nos autos. A ponderação, nessa linha, apresenta-se como uma consequência lógica de nosso sistema constitucional ${ }^{27}$.

Não é difícil notar que a ponderação se revela como um mecanismo normativo que fornece maior liberdade ao intérprete para reformar o material jurídico existente, pois com base na força normativa da Constituição é possível reler os compromissos estabelecidos tendo como parâmetro o peso maior dado a determinada norma constitucional por parte do intérprete. Como bem enfatiza Paulo Gonet Branco (2009, p. 7), "quanto mais abertura a textura normativa do ramo jurídico considerado, maior haverá o espaço para o confronto de teses igualmente razoáveis". Ao visualizar o texto constitucional como composto essencialmente por princípios, o Neoconstitucionalismo abre espaço para que haja cada vez mais soluções concorrentes para decidir os casos jurídicos. Assim, a ênfase na ponderação é outro indício de que essa corrente doutrinária se revela uma concepção jurídica basicamente voltada para a dimensão da justificação da prática jurídica. A defesa utilizada para defender esse novo modelo de decisão judicial é que a ponderação seria necessária para a correção dos argumentos e a concretização da justiça substantiva. Esse exercício de balanceamento de razões contidas em normas constitucionais, no entanto, não é aceito sem maiores críticas.

Um primeiro ponto que salta aos olhos é que, no caso Brown v. Board of Education, utilizado como inspiração da teoria neoconstitucional, não houve explicitamente qualquer ponderação. Em sua fundamentação, o Chief Justice Earl Warren interpretou a décima quarta emenda constitucional norte-americana como enunciadora de um princípio geral à igualdade que revogou a doutrina do "separate, but equal" estabelecida no caso Plessy. Caso outros bens ou valores fossem ponderados, como a violência que tal medida traria nos Estados segregacionistas do Sul, o resultado do caso talvez não tivesse sido o mesmo. Isso demonstra que a exigência de ponderação de valores para se chegar a um resultado emancipatório com base em interpretação de princípios não é necessário ou algo autoevidente. Com efeito, até hoje a doutrina do balancing encontra muita resistência na academia e na prática estadunidense ${ }^{28}$.

Na concepção de direito como integridade de Dworkin também não há uma etapa de balanceamento para se chegar a um resultado moralmente correto. Como visto, para o referido

\footnotetext{
${ }^{27}$ Virgílio Afonso da Silva (2002, p. 43) afirma que "a exigibilidade da regra da proporcionalidade para a solução entre direitos fundamentais não decorre deste ou daquele dispositivo constitucional, mas da própria estrutura dos direitos fundamentais",

${ }^{28}$ Cohen-Elya e Porat $(2010,265)$ constatam esse fato da seguinte maneira: "However, balancing has never attained the status of an established doctrine in U.S. constitutional law in the same way that proportionality has in European constitutional law. Moreover, balancing has always been the subject of fierce criticism and is very much a controversial concept in the U.S. constitutional law".
} 
autor o intérprete deve extrair dos compromissos políticos assumidos pela comunidade uma rede coerente de princípios que refletem a justificativa moral dada à prática jurídica como um todo. Assim, o juiz, ao julgar um processo, deve fazer uma reconstrução do material jurídico com a finalidade de identificar o princípio que informa a única resposta correta para o caso concreto. Por representarem direitos, os princípios possuem natureza deontológica, não se sujeitando a um regime de concorrência com outros bens ou valores. Como só há uma resposta correta até para os casos difíceis, só há, portanto, um princípio aplicável ao caso, que, por representar um trunfo, não pode ser negociado/balanceado. A ponderação seria considerada, na verdade, como um ato contrário à realização da justiça substantiva ${ }^{29}$.

Assim, nem a prática nem a teoria levam inexoravelmente à conclusão de que uma jurisdição constitucional transformadora deva necessariamente realizar um juízo de ponderação para alcançar resultados justos. Também não é possível dizer que o balanceamento é algo lógico-intuitivo em razão de uma suposta dimensão de peso que caracterizariam os princípios. Isso porque o que se percebe é que a aplicação de um princípio, assim como a de uma regra, impede a eficácia de outra norma jurídica na base do tudo ou $n a d a$, sem que isso represente a retirada de qualquer uma das duas espécies normativas do ordenamento jurídico.

Um exemplo pode ser didático nesse ponto: o Tribunal de Justiça do Distrito Federal e dos Territórios, ao analisar a legalidade da divulgação na internet de lista nominal com os salários dos auditores fiscais, decidiu que, no confronto entre o princípio da intimidade e o do direito a informação, o primeiro deveria prevalecer, ordenando a imediata retirada dos referidos contracheques do sítio eletrônico distrital ${ }^{30}$. Na prática, o princípio da intimidade foi aplicado com toda intensidade, retirando, no caso concreto, a eficácia normativa da outra norma. Da mesma forma ocorre quando há duas regras aparentemente aplicáveis a uma determinada situação: uma prevalece em detrimento da outra, sem que isso imponha a exclusão imediata de qualquer uma das duas do ordenamento ${ }^{31}$. Ou seja, o funcionamento de

\footnotetext{
${ }^{29}$ Dworkin (2001, p. 259) entende que os valores não entram em conflito quando eles são devidamente teorizados: "My main concern has been to warn against any lazy conclusion that political values just must conflict. We must do the work, against the background of an understanding about what it is to understand a value. So far as I have been able to carry the argument, the supposed conflict is an illusion, drawing one another, not in conflict."

${ }^{30}$ Tribunal de Justiça do Distrito Federal e Territórios, Mandado de Segurança nº 2012.00.2.015310-0, Des. Rel. Mário Machado, decisão liminar publicada no DJ-e de 18/07/2012.

${ }^{31}$ Em sentido semelhante, Humberto Ávila (2008, p. 55) afirma: "quando o aplicador atribui uma dimensão de peso maior a um dos princípios, ele se decide pela existência de razões maiores para a aplicação de um princípio em detrimento do outro, que, então, pode deixar de irradiar efeitos sobre o caso objeto da decisão. $O$ mesmo ocorre no caso da exceção à regra: o aplicador decide haver maiores razões para a aplicação da
} 
ambas as espécies normativas, quando há um aparente choque entre razões embutidas na norma, parece ser o mesmo.

Pode-se dizer, assim, que a ponderação, do mesmo como os demais elementos do Neoconstitucionalismo, é uma opção do intérprete ${ }^{32}$. Cumpre analisar, então, se sua utilização produz resultados mais satisfatórios no campo da concretização dos direitos fundamentais, já que esta é justificativa última do Neoconstitucionalismo.

Sobre esse tema, é importante notar que há duas tradições distintas quanto à ponderação: a proporcionalidade do direito alemão, desenvolvida com o claro intuito de proteger direitos contra a atividade estatal, e o balancing norte-americano, cuja construção foi voltada para a relativização do status conferido pela Suprema Corte a certos direitos ${ }^{33}$. Uma reconstrução histórica dessas duas tradições parece demonstrar que o Neoconstitucionalismo se aproxima mais da segunda opção, o que representaria uma forte crítica à adoção desse método interpretativo. Vale a pena, por esse motivo, um maior aprofundamento do tema.

A doutrina da proporcionalidade desenvolveu-se na Alemanha, desde a segunda metade do século XVIII, como um importante instrumento de proteção de direitos fundamentais $^{34}$ em um sistema jurídico que não conferia textualmente base legal para tais direitos. Sob a influência das teorias do contrato social, os próprios governantes da Prússia adotaram o entendimento de que seus poderes não eram ilimitados, mas subservientes aos objetivos de seu Estado. Imbuído desse espírito racionalista, o rei Friedrich Wilhelm III codificou o direito prussiano, albergando o embrião do princípio da proporcionalidade no art. 10(2) da Allgemeines Landrech de 1794, que preceituava que "o Estado deve utilizar os meios necessários para a manutenção da paz, segurança e ordem"35. Adotou-se, então, com base nessa cláusula legal, o entendimento de que o Estado somente poderia intervir na esfera de autonomia de seus cidadãos caso escolhesse os meios menos gravosos, estabelecendo-se uma limitação formal ao exercício do poder de polícia.

exceção em detrimento da regra. Isso indica que, no caso de conflito entre princípios, o princípio ao qual se atribui um peso menor pode deixar, na verdade, de ser aplicado".

32 No mesmo sentido, Alec Stone Sweet e Jud Matthews (2008, p. 75) concluem que: “[Proportionality Analysis]is a doctrinal construction: it emerged and then diffused as an unwritten, general principle of law through judicial recognition and choice".

${ }^{33}$ Grande parcela da doutrina pátria contrasta a proporcionalidade alemã com a razoabilidade norte-americana, afirmando que essa última ideia (reasonableness) surgiu integrada à noção de devido processo legal substantivo. Cf. PEREIRA, 2007, p. 155-156. Contudo, a nosso ver, a doutrina do balancing, por tratar exatamente de ponderação de direitos, se aproxima mais da corrente alemã da proporcionalidade do que os testes (scrutinies) empregados pela Suprema Corte americana para aferir a constitucionalidade das leis.

34 Sarlet, Marioni e Mitidiero (2012, p. 212) explicam que: “Originário do direito administrativo prussiano, o princípio da proporcionalidade, na sua forma inicial e até hoje reconhecida (embora reconstruída ao longo do tempo), guarda íntima vinculação com a ideia de controle dos atos do Poder Público, buscando precisamente coibir excessos de intervenção na esfera dos direitos dos cidadãos".

35 Tradução livre de SWEET;MATHEWS, 2008, p. 101. 
Durante o século XIX, a proporcionalidade foi empregada com bastante frequência pelos tribunais administrativos germânicos, notadamente pela Corte Administrativa Superior da Prússia que, durante a sua existência, declarou a nulidade de inúmeras políticas governamentais, tendo por base esse princípio. Nas décadas subsequentes, seu uso continuou intenso e a proporcionalidade ganhou cada vez mais prestígio, a ponto de Alec Stone Sweet e Jud Mathews afirmarem que "durante o período de 1875-1918 a revisão administrativa tornou-se de certa forma um 'substituto funcional para a ausência de controle de constitucionalidade' e os árbitros administrativos rotineiramente invocavam direitos na forma de princípios vinculantes ao Poder Executivo" ${ }^{\# 6}$. Dessa forma, antes das duas Grandes Guerras Mundiais, a proporcionalidade serviu, na Alemanha, como um efetivo mecanismo de reconhecimento de direitos em um sistema judicial que não possuía um catálogo constitucional que estabelecesse essas garantias fundamentais.

Logo após o fim do nazismo, a Lei Fundamental Alemã de 1949 estabeleceu a República Federal como uma nova ordem constitucional fundamentada no comprometimento com os direitos humanos, que passaram a integrar explicitamente o texto constitucional. Criou-se, então, a Corte Constitucional alemã, permitindo que os cidadãos reclamassem diretamente violações a seus direitos em um órgão jurisdicional designado para tanto. Como resultado de sua bem-sucedida trajetória na esfera administrativa, a proporcionalidade foi logo elevada a princípio de estatura constitucional. Em decisão datada de 1956, a Corte germânica reconheceu que esse princípio estaria implícito pela natureza dos direitos garantidos na Carta Magna combinado com o princípio do Rechsstaat ${ }^{37}$.

Nos anos subsequentes, a jurisprudência do tribunal constitucional alemão refinou seus requisitos do princípio da proporcionalidade. Inicialmente, na prática dos tribunais administrativos, analisava-se apenas se a política governamental implantada era apropriada para se alcançar ou fomentar os fins estatais a que se visava (requisito da adequação) e se o objetivo perseguido não poderia ser promovido por outro meio que limitasse em menor medida o direito fundamental atingido (requisito da necessidade) ${ }^{38}$. No caso Apothekenurteil, contudo, de 1958, a Corte Constitucional alemã foi mais adiante, formulando o teste da proporcionalidade em sentido estrito, que consistiu no balanceamento entre a intensidade da restrição a determinado direito fundamental e a importância da realização do interesse que

\footnotetext{
36 Tradução livre de SWEET; MATHEWS, 2008, p. 101.

37 Trata-se do caso 9 II VerfGH Bayern 158 (177), decidido em 28 de dezembro de 1956, citado por Stone Sweet e Jud Mathews (2008, p. 107).

38 Para uma análise mais minuciosa sobre os elementos da proporcionalidade, cf. SILVA, V., 2002, p. 34-41.
} 
com ele colide ${ }^{39}$. Restou estabelecido que mesmo uma medida considerada adequada e necessária pode ser declarada inconstitucional caso infrinja um direito fundamental em uma proporção maior do que a tolerável. Ou seja, o princípio da proporcionalidade exige que se faça um sopesamento entre os valores perseguidos pelo governo com uma política pública considerada adequada e necessária e o valor inerente ao direito fundamental violado no afã de se perquirir qual deve prevalecer no caso concreto.

Um ponto importante a ser destacado é que, conforme enfatizam Cohen Eliya e Porat (2010), a doutrina alemã da proporcionalidade foi construída com a clara intenção de fornecer um mecanismo formal pelo qual questões constitucionais pudessem ser decididas da maneira mais objetiva possível. Com a introdução da proporcionalidade em sentido estrito, finalizouse a elaboração de um verdadeiro método interpretativo, fundado em três etapas bem definidas, desenvolvido para lidar com temas de moralidade política com imparcialidade. Atualmente, em um sistema completamente constitucionalizado, a Corte Constitucional alemã utiliza o teste da proporcionalidade para analisar todos os casos em que se invoca a violação de direito fundamental, transformando-se em um standard transcendental que vincula os agentes públicos e privados. Não por outro motivo, a proporcionalidade tem sido denominada como o derradeiro Estado de Direito ${ }^{40}$ : todo o direito deve ser analisado sob a ótica da proporcionalidade.

A título de conclusão parcial, pode-se dizer que o princípio da proporcionalidade foi originariamente desenvolvido no contexto do direito administrativo, para introduzir a ideia de direitos fundamentais na Alemanha, que não possuía um catálogo, motivo pelo qual ele é normalmente associado à proteção de tais direitos. Originariamente, baseava-se em uma análise da existência de nexo entre os meios utilizados e os fins buscados pelo Estado. Desde a metade do século XX, entretanto, com a adoção de um catálogo constitucional de direitos e a elaboração da proporcionalidade em sentido estrito, ela passou a servir como método formal de balanceamento de interesses opostos, passando a ser utilizado para a solução de conflitos em todos os ramos do direito, inclusive no direito privado.

Já nos Estados Unidos, a doutrina do balancing surgiu em um contexto completamente distinto. Enquanto na Alemanha a proporcionalidade foi elaborada em razão da inexistência de reconhecimento constitucional de direitos, no ambiente norte-americano, a ponderação foi desenvolvida para limitar o alcance das cláusulas constitucionais enunciadoras de direitos. Ou

\footnotetext{
39 SWEET;MATHEWS, 2008, p. 107-112.

${ }^{40} \mathrm{O}$ termo foi cunhado por David Beatty (2004) para designar a proporcionalidade como método que permite a aferição da constitucionalidade das leis de maneira objetiva e imparcial.
} 
seja, o balancing foi construído como um instrumento interpretativo utilizado para restringir o alcance de direitos consagrados em face de interesses governamentais legítimos.

O contexto histórico-acadêmico de seu desenvolvimento é o do realismo jurídico e da malfadada Era Lochner, já mencionada no capítulo 1 desta Tese. Nesse período, a Suprema Corte americana, baseada em uma concepção formal e naturalística de direitos, declarou a inconstitucionalidade de inúmeras leis de cunho social, como as que fixavam salários mínimos e jornadas máximas de trabalho ${ }^{41}$. Os juristas realistas, como já visto, eram céticos quanto a interpretações que deduziam de maneira lógica direitos e princípios das cláusulas constitucionais, defendendo que o Direito, na verdade, deveria ser utilizado como instrumento para produzir boas consequências sociais. Assim, já que inexistiriam de antemão respostas jurídicas corretas, os juízes deveriam realizar um balanceamento entre os diversos interesses sociais em jogo para decidir a solução que produziria os melhores resultados para a sociedade como um todo. Na linha do pragmatismo filosófico, os realistas acreditavam que a verdade seria uma construção social, dissociada de qualquer elemento moral, refutando a ideia de direitos herdada do direito natural. Essa atitude cética fez com que a doutrina do balancing fosse identificada na academia norte-americana como uma alternativa ao formalismo ${ }^{42}$. Cohen-Eliya e Porat resumem bem essas características:

O balanceamento progressista era, portanto, hostil quanto aos direitos constitucionais em duas importantes e correlatas formas. Primeiro, ele buscava igualar direitos com interesses. Direitos não eram nada mais do que interesses sociais particulares e, então, poderiam ser balanceados contra outros interesses. Em particular, para elevar direitos acima de interesses em categorias separadas e diferenciadas era considerado como uma atitude retórica e manipuladora, utilizada apenas para promover os objetivos ideológicos da Corte.

Segundo, os progressistas acreditavam que o balanceamento deveria ser realizado pelo Legislativo. O professor Horwitz esclarece essa visão: "Se o Direito é apenas um campo de batalha em que interesses sociais colidem, então o Legislativo é a instituição apropriada para medir e pesar os interesses concorrentes". E ele acrescenta que "no período em que o livro The Path of

\footnotetext{
${ }^{41}$ Paulo Gonet Branco (2009, p. 90) reconhece que "foi para derrotar a jurisprudência que levara à crise entre Executivo e Judiciário, durante o New Deal, que, pela primeira vez, a Suprema Corte, pela maioria de seus integrantes, empregou o juízo de ponderação. A calibragem de interesses confrontantes foi o método encontrado para ler a Constituição em sentido deferencial para com o legislador. Foi assim que se pôs fim ao primeiro periodo de ativismo judicial nos EUA, iniciado com o caso Lochner".

42 Alexander Aleinikoff (1987, p. 949) afirma, nesse sentido, que "balancing was a major break with the past, responding to the collapse of nineteenth century conceptualism and formalism as well as to half a century of intellectual and social change. Building on the work of Holmes, James Dewey, Pound, Cardozo, and the Legal Realists, and flying the flags of pragmatism, instrumentalism and science, balancing represented one attempt by the judiciary to demonstrate that it could reject mechanical jurisprudence without rejecting the idea of law".
} 
Law foi redigido, o foco do darwinismo de Holmes havia mudado das cortes para os parlamentos" $"$.

Apesar de sua ampla influência na revogação do precedente Lochner, tendo sido utilizada explicitamente por renomados Justices, como Oliver Wendell Holmes Jr., a doutrina do balancing teve vida curta na jurisprudência da Suprema Corte americana. Logo na década seguinte, ela serviu de base para uma das decisões consideradas trágicas pela doutrina especializada, o precedente Dennis v. United States $^{44}$. Os dados do caso são os seguintes: no auge da campanha anticomunista do Presidente Joseph McCarthy, membros do Partido Comunista Norte-Americano foram condenados pelo crime de conspiração, previsto no Smith Act, pelo simples fato de terem estabelecido o referido partido político e difundido as ideias marxistas. Em seu recurso submetido à Suprema Corte, os réus alegavam violação ao direito de liberdade de expressão contido na Primeira Emenda. A penalidade foi mantida, tendo o Justice Frankfurter afirmado, em seu voto, que os direitos fundamentais não deveriam ser encarados de maneira formal e absoluta, mas contrapostos aos demais interesses da sociedade, o que o levou a balancear o direito à liberdade de expressão com o interesse social na manutenção segurança nacional, privilegiando este último.

Em uma sociedade que tem o direito à liberdade de expressão em alta consideração, como a dos Estados Unidos, sua limitação sem que houvesse qualquer ameaça ou risco iminente fez com que esse caso fosse considerado um mau exemplo de interpretação constitucional $^{45}$. O perigo de restrição injustificada de direitos com base em argumentos estratégicos fez com que a doutrina do balancing fosse abandonada pelos juristas progressistas americanos, o que explica a ausência de um teste semelhante ao da proporcionalidade na jurisprudência estadunidense $\mathrm{e}^{46}$.

Apresentadas as duas tradições jurídicas em que surgiram métodos interpretativos baseados em ponderação, parece evidente que o Neoconstitucionalismo se assemelha mais à tradição norte-americana. A luta contra o formalismo associado ao positivismo jurídico e a busca por formas interpretativas mais flexíveis são temas recorrentes nos trabalhos dos

${ }^{43}$ Tradução livre de COHEN-ELIYA; PORAT, 2010, p. 282.

44 Dennis v. United States, 341 U.S. 494 (1951)

${ }^{45}$ Erwin Chemerinsky (2006, p. 997) concorda com essa interpretação, afirmando que "especially from the perspective of hindsight, Dennis seems terribly misguided; individuals were punished for doing no more than reading and talking about four books that are now a regular part of many college courses".

${ }^{46}$ Segundo Cohen-Elyia e Porat, "Dennis symbolizes the dangers stemming from the use of balancing: the danger of judicial capitulation to the legislature in times of national security crises. Nor is it surprising to note that the liberal Warren Court dissociated itself completely from the idea of balancing, in part, as a consequence of the stigma attached to Dennis. Most of the major constitutional decisions of the Warren Court avoided balancing rhetoric. Some Warren Court decisions even rejected balancing explicitly". No mesmo sentido, cf. TSAKYRAKIS, 2009, p. 469-470. 
neoconstitucionalistas. Imaginar que esses autores buscam com a ponderação o estabelecimento de um método rígido e formal para tratar de maneira camuflada de temas morais, como é a proporcionalidade para os alemães, é contraditório com o próprio projeto de criatividade judicial e de reabilitação da moral por eles defendidos. Além disso, ao permitir a ponderação entre direitos e valores, essa corrente doutrinária reduz tudo a interesses que devem ser sopesados na busca pelos resultados desejados ${ }^{47}$, da mesma forma como defendido pelos realistas. Aliás, esse uso instrumental da interpretação constitucional por parte dos autores nacionais é, como já visto no capítulo 1, uma herança do realismo jurídico. Por fim, a ponderação é empregada pelos autores nacionais em um sistema jurídico que já constitucionalizou os direitos, enquanto a proporcionalidade originariamente surge para “desvendar" direitos em um ordenamento que não os protege explicitamente.

Mesmo na Alemanha, após a constitucionalização do catálogo de direitos fundamentais, a proporcionalidade não pode mais ser concebida como sinônima de proteção a direitos. De fato, se em sua origem no direito administrativo toda aplicação desse princípio envolvia o reconhecimento de direitos contra o Estado, atualmente, muito do trabalho hermenêutico envolvido em sua aplicação resulta na limitação do alcance de norma constitucional protetiva de direitos em face de outros fins estatais igualmente considerados relevantes ${ }^{48}$.

Nessas circunstâncias, os direitos fundamentais passam a ser fluidos e contingenciais, gerando certa perplexidade para uma teoria constitucional que pretende ser contramajoritária. Essa faceta fica mais evidente com a inclusão da proporcionalidade em sentido estrito no teste acerca da constitucionalidade das normas: como quase nenhum ato estatal é baseado em premissas absolutamente irracionais, normalmente o preenchimento dos elementos da adequação e da necessidade é satisfeito. As questões constitucionais são, na maioria das vezes, reduzidas ao sopesamento da intensidade dos valores supostamente em contraposição para definir qual interesse - se o pessoal ou da coletividade - deve prevalecer no caso concreto. Em suma, a proporcionalidade ao estilo germânico enseja uma atitude hermenêutica de análise de custo/benefício com relação à aplicação dos direitos fundamentais que dificilmente pode ser reconciliada com uma concepção que justifica a prática jurídica a partir

\footnotetext{
${ }^{47}$ Waldron (1999, p. 242) explica, nesse sentido, que: "A right with an instrumental justification is always liable to managerial manipulation, limiting the right or modifying its exercise in order to fine-tune the generation of socially desirable consequences. And this seems to be at odds with the 'trumping' function of rights, which is precisely to set limits on the pursuit of social utility".

${ }^{48}$ COHEN-ELYA, PORAT, 2010, p. 284-286.
} 
desses mesmos direitos. Dito de outra forma, a possibilidade de negociação de direitos com interesses faz com que eles percam a sua essência ${ }^{49}$.

De qualquer forma, o que parece ser importante para o presente exame é que a ponderação valorizada pelos neoconstitucionalistas, seja ela na versão alemã ou na americana, ao reduzir direitos a valores e interesses, afrouxa o dever dos juízes de decidirem de acordo com as normas jurídicas vigentes, abrindo espaço para a discricionariedade e o arbítrio ${ }^{50}$. A ponderação, portanto, distorce o argumento jurídico, possibilitando a manipulação dos compromissos institucionais assumidos por meio da relativização dos direitos das partes. Isso se torna muito claro na obra de Eduardo Ribeiro Moreira, que afirma categoricamente que, no Neoconstitucionalismo, o balanceamento entre argumentos de princípio e de política passa a ser uma necessidade:

Na teoria de Dworkin, uma distinção não se aplica ao direito brasileiro (...). Dworkin denomina princípio um padrão a ser observado como exigência de justiça, que funciona não só em oposição às regras, mas também em oposição às políticas públicas (policies). (...) No direito brasileiro, contudo, pela busca da melhor decisão possível, em conformidade com a Constituição, deve-se realizar a ponderação entre o público (políticas públicas, sobretudo quando de interesse público primário) e o individual fundamental privado (por princípios de natureza fundamental) ${ }^{51}$.

E não se diga que a presente crítica é irrelevante com o argumento de que a ponderação seria algo natural, realizado mentalmente pelo intérprete, mesmo quando não o explicite em sua decisão. Obviamente, as respostas jurídicas corretas e os princípios morais não são revelados por um ente divino, mas oriundos de um raciocínio substantivo em que os diversos valores são colocados em ordem de preferência. Como bem assevera Jeremy Waldron (1994), quando Ronald Dworkin estabelece os seus trunfos ou John Rawls afirma que a liberdade prevalece sobre qualquer outro bem, ambos os autores estão realizando uma ponderação de valores, mas uma ponderação bem diferente daquela proposta por utilitaristas e aparentemente endossada pelos neoconstitucionalistas. Trata-se, na verdade, de um exercício reflexivo anterior, em que se constitui uma ordem de prioridades entre os diversos valores existentes em razão de seus méritos, estabelecendo-se um sistema moral coerente, com

\footnotetext{
49 TSAKYRAKIS, 2009, p. 474-475.

${ }^{50}$ Habermas (2003, p. 321) conclui de maneira semelhante. Para ele, "normas e princípios possuem uma força de justificação maior do que a de valores, uma vez que podem pretender, além de uma especial dignidade de preferência, uma obrigatoriedade geral, devido ao seu sentido deontológico de validade; valores têm que ser inseridos, caso a caso, numa ordem transitiva de valores. E, uma vez que não há medidas racionais para isso, a avaliação realiza-se de modo arbitrário ou irrefletido".

${ }^{51}$ MOREIRA, 2008, p. 97.
} 
pretensão de validade universal. Quando se diz, por exemplo, que a dignidade da pessoa humana deve sempre prevalecer, está subentendido que o valor inerente à vida humana tem prioridade, ou seja, é mais importante do que os demais interesses coletivos.

A partir da fixação dessa orientação normativa, os valores mais importantes passam a prevalecer sobre os de menor intensidade, não se falando mais em ponderação. Já os princípios informam como as pessoas devem agir com vistas a manter de forma hígida essa ordem de valores, independentemente das preferências e dos interesses de cada um. Ou seja, princípios não se confundem com valores: indicam o que deve ser feito para que os valores considerados prioritários não sucumbam diante de valores de menor importância, consubstanciando-se em uma diretriz normativa. Essa atitude interpretativa exige que, em uma circunstância concreta, se procure identificar qual o valor tem prioridade e, portanto, qual princípio válido tem aplicação. Caso a liberdade de expressão seja mais relevante do que a intimidade de pessoas públicas, então o princípio que informa esse direito constitucional tem aplicação. Não há que se falar em conflito de princípios: deve-se aplicar aquele que indica corretamente a ordem de prioridades dos valores existentes.

É claro que certas situações ensejarão novas sensibilidades políticas e morais, tornando a ordem de valores anteriormente elaborada pouco atrativa. Nessas circunstâncias, o intérprete deverá realizar um exercício hermenêutico complexo com vistas a estabelecer uma nova ordem apta a solucionar o caso que lhe foi apresentado. Contudo, os valores não devem ser aferidos em razão dos interesses dos envolvidos, mas em virtude de seus méritos. A prioridade deve ser dada àquele valor que melhor justifique a prática jurídica como um todo, tornando-a moralmente atrativa. Realizada essa reflexão, aplica-se o princípio válido que represente o modo como esses valores foram alinhados.

O utilitarismo ${ }^{52}$, por outro lado, parte do pressuposto de que não há nenhuma ordem prioridade entre valores, motivo pelo qual, diante de um caso concreto, busca-se a solução que promova a maximização dos interesses envolvidos. A doutrina da análise econômica do Direito, na vertente defendida por Richard Posner (1981) em seu livro The Economics of Justice, é um exemplo de interpretação judicial utilitarista que usa a eficiência econômica como critério para solução de conflitos. O que diferencia as teorias utilitaristas das deontológicas $^{53}$ é que, enquanto as primeiras buscam estabelecer uma medida (felicidade,

\footnotetext{
${ }^{52}$ Waldron (1999, p. 216) explica que: "Utilitarianism has, in or near its foundations, a sense that the basic aim of morality is the maximization of utility. Whenever there is a choice of actions, it is better, from the theory's point of view, that that action be chosen which secures the greatest balance of utility, all things considered".

53 Teorias deontológicas são teorias que reconhecem a prioridade de certos valores consubstanciados em direitos (right-based theories). Como bem assevera Waldron (1999, p. 225): "To believe in rights is to believe that
} 
riqueza, etc.) para comparar os valores concorrentes, as segundas partem do pressuposto de que há uma hierarquia a ser obedecida, por mais que ela não seja de fácil identificação no caso concreto. Enquanto para os utilitaristas o único princípio válido é aquele que ordena que o intérprete deva escolher a solução que traga o maior benefício (econômico, por exemplo) possível para a sociedade, para a segunda tradição filosófica há vários princípios que impõem o dever de agir em determinado sentido com vistas a preservar os valores considerados superiores. Os direitos, nesse sentido, são considerados trunfos por simbolizarem valores prioritários que não podem ser comparados aos demais interesses da sociedade.

Ao reduzir os direitos fundamentais e os princípios constitucionais a valores que devem ser sopesados com os interesses públicos, o Neoconstitucionalismo dá a entender que não há qualquer ordem de prioridade, retirando a proeminência dos direitos e igualando-os às considerações estratégicas.

A própria linguagem da proporcionalidade, ao tratar princípios como mandados de otimização ${ }^{54}$, indica que o intérprete está lidando com valores de mesma estatura hierárquica que podem ser confrontados. Essa ideia de comensurabilidade acaba erodindo a função bloqueadora dos direitos fundamentais, que deixam de possuir um significado moral superior. Em resumo, ao se utilizar de testes que envolvam sopesamento/balanceamento de princípios com interesses outros, o intérprete se condiciona a raciocinar como se não houvesse uma ordem prioritária de valores a ser obedecida. Como bem adverte Dworkin, "a metáfora é profundamente enganosa porque assume que devemos decidir sobre quais direitos humanos devem ser reconhecidos por meio de uma análise de custo/benefício" 55.

Há, portanto, uma relevante diferença interpretativa entre uma decisão que busca estabelecer a única resposta correta, aplicando o princípio que reflita o esquema prioritário de valores estabelecido pela sociedade por meio de seus compromissos institucionais assumidos, de uma que se utilize explicitamente da ponderação como método hermenêutico.

Como consequência da utilização de esquemas de balanceamento as decisões judiciais não se preocupam em decidir o que é certo ou errado, mas o que é adequado ou razoável. Os juízes veem-se autorizados a ponderar todos os tipos de argumentos na análise da constitucionalidade das leis, tornando irrelevante o adjetivo fundamental ao lado da expressão

certain key interests of individuals, in liberty and well-being, deserve special protection, and that they should not be sacrificed for the sake of greater efficiency or prosperity or for any aggregate of lesser interests under the heading of the public good".

${ }^{54}$ Esta expressão é de Robert Alexy (2008, p. 118), para quem a “máxima da proporcionalidade em sentido estrito decorre do fato de princípios serem mandamentos de otimização em face das possibilidades jurídicas".

55 DWORKIN, 2006a, p. 1. 
“direitos fundamentais", pois eles também passam a ser passíveis de comparação ${ }^{56}$. A utilização explícita de um esquema de ponderação dilui a divisão entre atividade judicial e legislativa, incitando uma participação cada vez maior dos tribunais na vida política da sociedade. Essa é, de fato, uma conclusão empírica a que chegou a pesquisa realizada por Alec Stone Sweet e Jud Matthews:

Em todos os sistemas examinados, descobrimos que uma guinada jurisprudencial da Corte para o uso da análise da proporcionalidade gerou mecanismos que serviram para aumentar radicalmente o papel do Judiciário, tanto na criação do direito como no desenvolvimento constitucional ${ }^{57}$.

Nota-se, portanto, que a ponderação é um instrumento que facilita a reforma dos compromissos assumidos pela sociedade por meio da intepretação constitucional, pois dá a entender que não há uma ordem prioritária de valores, permitindo que o intérprete os manuseie como bem entender. Na visão do neoconstitucionalista, a Constituição oferece uma gama de razões não decisivas. Tudo é reduzido a valores que, por possuírem a mesma unidade de peso, podem ser balanceados no caso concreto. Essa liberdade de reinterpretar o sentido das cláusulas constitucionais à luz dos valores em conflito permite o trânsito entre as dimensões da adequação e da justificação, reduzindo drasticamente a importância das decisões institucionais passadas na solução do caso presente. Tudo é passível de revisão a depender dos valores que sejam contrastados.

Em razão do princípio da máxima efetividade das normas constitucionais e do fenômeno da constitucionalização do Direito - ambas as teses defendidas pelos neoconstitucionalistas - além de toda questão jurídica se transformar em questão constitucional, torna-se possível em todo caso ponderar as diversas razões existentes no Texto Fundamental. Dilui-se, assim, a ideia de autoridade do Direito, pois todas as razões legais tornam-se razões não excludentes que devem ser ponderadas com outras razões relevantes para o intérprete. Isso faz com que todas as normas e precedentes estejam em constante questionamento, já que uma alteração no balanço dos interesses em jogo, inclusive o interesse

\footnotetext{
56 Stravos Tsakysaris (2009, p. 470), ao analisar a aplicação do princípio da proporcionalidade em várias jurisdições, chega a conclusão semelhante: "The view that constitutional rights are nothing but private interests whose protection depends, on each occasion, on being balanced with competing public interests, in fact, renders the Constitution futile. Indeed, if constitutional rights protect the same kind of interests as those of the government, and if the protection depends on considerations of some kind of relative 'weigh' given to conflicting interests, it follows that the protection accorded by the Constitution can never be stable but is always conditional on various circumstance and depends on the outcome of balancing. On this view, not only is it doubtful whether the Constitution is the kind of law that includes stable and knowable propositions, but it also renders the very idea of such constitution futile".

57 SWEET; MATHEWS, 2008, p. 161.
} 
do intérprete, pode ensejar a decretação da inconstitucionalidade do material jurídico anteriormente consolidado.

utra consequência da adoção da ponderação por parte do Neoconstitucionalismo é que, como há uma infinidade de normas constitucionais endossando valores distintos, a proporcionalidade passa a ser o próprio parâmetro de controle. Como todo caso jurídico é um caso constitucional e como sempre há valores em conflito, sempre haverá a necessidade de se realizar um juízo de ponderação que, como visto, é resolvido pela aplicação dos princípios da proporcionalidade e/ou da razoabilidade. Nesse diapasão, torna-se possível dizer que, no paradigma neoconstitucional, o Poder Judiciário se transforma em julgador das escolhas do legislador, pois realiza um crivo de proporcionalidade de todos os atos estatais. Não por outro motivo o Supremo Tribunal Federal, na já mencionada Medida Cautelar na Ação Direta de Inconstitucionalidade $n^{\circ} .4 .467$, seguindo o voto da Ministra-relatora Ellen Gracie, declarou a inconstitucionalidade de exigência de dupla titulação para votação com base única e exclusivamente no princípio da razoabilidade, que sequer está plasmado em nossa Carta Magna.

Até mesmo as regras passam a ser passíveis de ponderação nesse paradigma jurídico. Através da identificação das razões subjacentes a determinada regra, torna-se possível ponderá-las com os demais valores constitucionais para, se for o caso, afastar sua aplicação. Trata-se exatamente daquilo descrito por Eduardo Ribeiro Moreira (2008, p. 88-91) como fenômeno da derrotabilidade das regras que ocorre quando os efeitos de sua aplicação se revelam incompatíveis com outros preceitos constitucionais. Alguns ministros do Supremo Tribunal Federal parecem ter adotado esse posicionamento no julgamento do Recurso Extraordinário $n^{\circ} .630 .147^{58}$, em que se discutia a aplicação da chamada Lei da Ficha Limpa às eleições de 2010, já citado na introdução desta Tese, afastando a aplicação do art. 16 da Constituição Federal tendo por base o princípio da moralidade.

É claro que em algumas situações extraordinárias as regras podem deixar de ser aplicadas em virtude do que chamarei genericamente de equidade, ou seja, quando a sua aplicação se revela absolutamente incompatível com o próprio objetivo da norma. Mesmo nessas situações excepcionalíssimas, a regra deixa de ser aplicada não em razão de sua incompatibilidade com a Constituição da República - senão ela seria na verdade inconstitucional prima facie -, mas devido à falta de logicidade de sua utilização naquele caso

\footnotetext{
${ }^{58}$ Supremo Tribunal Federal, Recurso Extraordinário nº. 630.147, Min. Rel. Ayres Britto, julgado em 29/09/10, acórdão publicado no DJ-e de 05/12/11.
} 
específico $^{59}$. A banalização do discurso constitucional e da ponderação, inerentes ao pensamento neoconstitucional, faz com que a interpretação dada por alguns juízes no caso da Ficha Limpa, em que uma regra constitucional válida cuja aplicação se mostrava evidente foi afastada com a finalidade de reformar a sociedade, passe a ser considerada algo trivial.

De todo o exposto é possível extrair conclusões importantes com relação ao elemento ponderação do Neoconstitucionalismo. Em primeiro lugar, restou demonstrado que a utilização da proporcionalidade decorre da adoção voluntária de uma postura interpretativa que, a despeito de conferir uma maior flexibilidade hermenêutica, desencadeia uma série de efeitos colaterais, muitas vezes contraditórios com a própria ideia de proteção de direitos. Assim, a utilização explícita da proporcionalidade em um argumento jurídico pode ser considerada um sintoma de que o intérprete se alinha ao pensamento neoconstitucionalista. Em segundo lugar, o exercício da ponderação se revela incompatível com o pensamento de Ronald Dworkin, de maneira que sua menção como um dos precursores do Neoconstitucionalismo mostra-se equivocada ou no mínimo questionável. Para o referido autor, por mais que o ordenamento jurídico seja complexo e apresente comandos jurídicos muitas vezes contraditórios, cumpre ao intérprete identificar o princípio que corretamente relaciona os diversos valores albergados pelo texto constitucional, apresentando a única resposta correta para o caso concreto. Essa atitude faz total diferença, já que transfere aos órgãos políticos o juízo de ponderação das razões que dão azo aos princípios compartilhados pela comunidade. Em terceiro, a utilização dos princípios da proporcionalidade e da razoabilidade modifica de maneira inequívoca o raciocínio jurídico, colocando juízes como protagonistas da transformação da sociedade.

\footnotetext{
${ }^{59}$ Frederick Schauer (1991, p. 31-37) afirma haver três situações em que uma regra acaba por gerar controvérsias com relação a sua aplicação: a primeira ocorre quando uma regra abrange casos que não deveriam ser por ela abarcados em razão da utilização pelo legislador de uma expressão inespecífica (overinclusiviness); a segunda é quando os termos utilizados para prescrever uma norma exclui uma situação que deveria ter sido por ela abrangida (underinclusiviness); e, a última e mais importante situação decorre da textura aberta da linguagem humana. Segundo o referido autor, com relação a este último aspecto, por mais que uma regra especifique nos mínimos detalhes a situação na qual ela deva incidir, a compreensão da expressão utilizada com o tempo passa a assumir nova significação, em parte em virtude da falibilidade humana, em parte devido ao nosso conhecimento imperfeito e em parte porque o mundo é variável, o que faz com que uma regra estabelecida a partir de uma relação empírica entre a justificativa da norma e a generalização nela prescrita se torna, com o tempo, obsoleta ou imprecisa. Na verdade, a ideia de derrotabilidade da norma perde o sentido ao se compreender o Direito como um conceito interpretativo no sentido dworkiano, pois ao realizar uma interpretação construtiva do material jurídico o hermeneuta conclui que a utilização da norma em determinado caso não apresenta a prática jurídica em sua melhor forma em razão de algum dos motivos listados por Schauer, afastando a sua incidência.
} 


\section{6 - Neoconstitucionalismo: uma espécie de pragmatismo jurídico?}

O objetivo do presente capítulo era explorar as teses do Neoconstitucionalismo, a fim de identificar os valores cultuados por seus adeptos, bem como a forma como as dimensões da adequação e da justificação estão alinhavadas nessa concepção jurídica. O Direito como prática interpretativa comporta uma série de concepções distintas, a depender dos elementos e valores identificados como casos centrais da prática pelo intérprete. No caso do Neoconstitucionalismo, está claro que se trata de uma teoria cujo principal foco é a substância das decisões. Sua vocação é ser uma teoria transformadora, voltada para a reforma da sociedade, valorizando o ativismo judicial e a mudança social em detrimento dos valores da democracia e da segurança jurídica.

Todos os elementos da teoria neoconstitucional ressaltados neste capítulo fornecem um arsenal teórico apto a ensejar uma atuação judicial voltada para o futuro, desvinculada das amarras institucionais normalmente associadas ao formalismo jurídico. A dimensão da adequação é resumida a uma simples recondução ao ordenamento jurídico por meio de menção a princípios que ao final são ponderados mediante um exercício que envolve a análise de custo/benefício entre diversos interesses e fins albergados no texto constitucional.

Esse pacote de opções interpretativas confere aos adeptos ao Neoconstitucionalismo a possibilidade de reformar judicialmente os compromissos assumidos pela sociedade, sem maiores constrangimentos. Caso haja uma norma jurídica que leve a resultados considerados indesejados, basta afastar sua aplicação com base no princípio da proporcionalidade. O que realmente importa para essa concepção é verificar se o conteúdo do material jurídico está em consonância com aquilo que o intérprete entenda ser o correto, colocando em xeque a validade de todo o ordenamento jurídico, que está em constante questionamento.

Dimitri Dimoulis (2009) afirma que a característica marcante do Neoconstitucionalismo seria a defesa da tese da necessária conexão entre Direito e moral, o que tornaria essa doutrina uma espécie de moralismo jurídico. Reconhecendo o Direito como um conceito interpretativo, não há dúvidas de que a moral exerce um papel na identificação e na aplicação da Constituição, seja qual for a concepção jurídica adotada. Conforme se argumentou no capítulo anterior, elaborar uma teoria meramente descritiva e imparcial não se mostra viável, pois sempre há uma escolha subjetiva dos elementos que compõem o caso central da prática jurídica pelo intérprete. Resta saber, entretanto, o que significa essa relação entre Direito e moral para o Neoconstitucionalismo. O utilitarismo, por exemplo, é uma teoria 
moral $^{60}$ que afirma que as pessoas devem agir de maneira a maximizar o bem-estar global da sociedade. Para se identificar a vertente moral subjacente à teoria neoconstitucional torna-se necessário responder às seguintes perguntas: Como seus adeptos decidem os casos judiciais? O que torna uma proposição jurídica válida para essa concepção jurídica? As respostas a esses questionamentos possibilitam encontrar o parâmetro normativo por eles utilizado.

Como já visto, para o Neoconstitucionalismo a mera consistência com o material jurídico não possui valor algum caso o seu mérito da decisão esteja em desacordo com os requisitos substantivos que, na visão do intérprete, são impostos pela Constituição. Ocorre que o parâmetro utilizado pelos neoconstitucionalistas para realizar essa avaliação de correspondência é muitas vezes confuso e particularmente indefinido. Em alguns casos, após efetuar um juízo de ponderação, um direito fundamental deve prevalecer sobre interesses coletivos. Em outros, não. Normas programáticas, valores e objetivos políticos são misturados e comparados a direitos e, ao final, prevalece o que nas circunstâncias específicas do caso concreto parece produzir os melhores resultados sociais para a sociedade. As normas jurídicas, como o art. 16 da Constituição Federal de 1988, somente devem ser observadas se as consequências decorrentes de sua aplicação se mostrarem compatíveis com o juízo substantivo formulado pelo intérprete. Caso contrário, podem ser derrotadas ou declaradas inconstitucionais.

O problema do Neoconstitucionalismo é que não somente os argumentos de princípio - que estabelecem direitos individuais exigíveis de modo universalizável - são considerados juridicamente relevantes, mas também os argumentos de política - que fixam objetivos coletivos, relacionados sempre com o bem-estar de uma parcela da sociedade, mas nunca com sua totalidade, haja vista a existência de desacordos razoáveis em uma sociedade plural. Assim, para que um direito seja reconhecido, torna-se necessário que o intérprete se convença de que esse reconhecimento é, dentre as opções existentes, a melhor para a comunidade.

$\mathrm{O}$ viés redistributivo e emancipatório inerente ao pensamento neoconstitucional faz com que as decisões políticas passadas consagradoras de direitos possam ser ignoradas em uma disputa jurídica se contrárias às metas coletivas endossadas pelo juiz. Não é possível,

\footnotetext{
${ }^{60}$ O termo "teoria moral" aqui utilizado significa o fornecimento de um parâmetro normativo sobre como as pessoas devem agir e está sendo empregado em oposição aos projetos teóricos que se consideram neutros, como o positivismo jurídico. Nesse sentido, não só as teorias baseadas em direitos (right-based) são morais, mas todas que procuram influir no modo de agir das pessoas. A moralidade, portanto, está associada à ideia de responsabilidade em agir de determinada forma na convicção de que essa atitude é a mais correta, enquanto a argumentação moral é o exercício pelo qual se busca justificar determinada convicção. Em suma, toda atitude valorativa é moral. Mesmo o niilismo, ao endossar o argumento de que nada há que indique que uma resposta é moralmente correta ou equivocada, é uma teoria moral substantiva no sentido de que adota um ponto de vista valorativo. (DWORKIN, 2006, p. 78-81).
} 
contudo, afirmar que o Neoconstitucionalismo incorpore uma doutrina jurídica de nítido cunho socialista. As ferramentas para uma revolução da sociedade pela via judicial estão à disposição do intérprete, mas sua utilização é apenas uma das opções existentes.

Essa ausência de critério normativo definido, que na verdade é apenas um dos reflexos da atitude de não considerar a Constituição uma ordem prioritária de valores, faz com que o Neoconstitucionalismo se aproxime do pragmatismo jurídico ${ }^{61}$, corrente doutrinária bastante influente nos Estados Unidos, cuja principal tese é de que os juízes devem tomar as decisões que tragam o maior benefício possível para a sociedade, independentemente do que foi estabelecido no passado. Richard Posner, talvez o mais influente adepto dessa postura teórica, assim define o pragmatismo jurídico:

Juízes pragmáticos sempre tentam fazer o melhor para o presente e para o futuro, não controlados por nenhum sentimento de obrigação em assegurar uma consistência de princípios com o que outros agentes públicos fizeram no passado. (...) Nessas circunstâncias, a diferença entre um juiz pragmático e um juiz que é positivista no sentido forte de acreditar que o Direito é um sistema de regras postas pelo legislativo e meramente aplicadas pelos magistrados é que, enquanto para este último tipo de juiz a sua principal preocupação é assegurar a consistência entre as decisões e os atos normativos passados, o primeiro está preocupado em guardar consistência com o passado apenas quando o ato de decidir de acordo com o precedente é o método apropriado para produzir os melhores resultados para o futuro ${ }^{62}$.

A compreensão das normas constitucionais como valores que devem ser ponderados no momento de sua aplicação é a porta de entrada para os argumentos pragmáticos no Neoconstitucionalismo. Do mesmo modo como o pragmatismo jurídico, o Neoconstitucionalismo se interessa pelo conteúdo das decisões em razão de suas consequências. O discurso constitucional é utilizado como instrumento de promoção de avanços sociais e para, assim, promover a reforma da sociedade. A transformação almejada, no entanto, não é clara. Um dos principais objetivos de seus membros, como visto, é a redistribuição de renda, o que faz com que os juízes enveredem por argumentos de política. Não há, entretanto, uma pauta normativa definida. A cada caso o critério pode ser modificado para se ajustar às preferências estratégicas do intérprete, minando qualquer ideia de vinculação ao Direito. A resposta à pergunta como decidem os juízes neoconstitucionalistas é

\footnotetext{
${ }^{61}$ Écio Oto Duarte chega a conclusão semelhante para quem "o sentido do pragmatismo se evidenciaria quando a determinação do conceito de direito se toma como ponto útil e, portanto, orientado à prática. (...) Nesse sentido, a prioridade do caráter prático (...) impulsiona o paradigma neoconstitucional à inclusão, também, da dimensão política do direito". (DUARTE; POZZOLO, 2006, p. 64-65).

${ }^{62}$ Tradução livre de POSNER, 2002, p. 241.
} 
uma incógnita, pois não há como se saber de antemão qual valor constitucional vai ser priorizado em um litígio ${ }^{63}$.

O que se defende na presente Tese é que há uma moralidade intrínseca na ideia de vincular de antemão os resultados das causas levadas ao Poder Judiciário que se perde quando os juízes julgam com base nas próprias razões. A dignidade do Estado de Direito pode ser traduzida nos valores da liberdade, da igualdade de tratamento, da coordenação de condutas, da eficiência e da democracia. Em outras palavras, uma interpretação construtiva da prática jurídica parece indicar que a limitação que a dimensão da adequação impõe aos magistrados possui méritos que reclamam uma releitura da postura neoconstitucional de focar excessivamente na substância das decisões judiciais.

A limitação da atividade estatal (o que inclui a judicial) por meio do estabelecimento prévio de razões legais excludentes é um ideal político venerado nas sociedades contemporâneas. Ao incitar os intérpretes a rediscutirem judicialmente os méritos dos compromissos políticos assumidos pela sociedade, o Neoconstitucionalismo está em constante tensão com esse ideal político em dois sentidos: primeiro, ao colocar em xeque a validade de todas as normas jurídicas, deixando os cidadãos desorientados sobre como agir; segundo, ao pulverizar o critério normativo mediante os quais os litígios sobre a aplicação dessas mesmas normas serão decididos. Nos próximos capítulos será feita uma reconstrução interpretativa do conceito de Estado de Direito, apontando valores e elementos a ele inerentes, para detectar com mais clareza os pontos em que o Neoconstitucionalismo põe em risco esse ideal político.

\footnotetext{
${ }^{63}$ No mesmo tom crítico, Carlos Horbach (2007, p. 88) afirma que "na interpretação da lei ou da Constituição, os 'neoconstitucionalistas' separam o termo do conceito, o conceito do preceito, o preceito da norma, a norma do texto e o texto do contexto, para, ao final dessa operação, fazer com que o dispositivo afirme exatamente o que desejam e, não raro, o contrário do que nele está escrito".
} 


\section{Capítulo 5 - Reconstruindo o Estado de Direito}

\section{1 - Estado de Direito e autoritarismo}

O Estado de Direito é normalmente associado ao estabelecimento de um "governo de leis e não de homens", expressão consagrada no art. 30 da Declaração de Direitos de Massachussets, de $1780^{1}$. Sendo este um ideal político cultuado de maneira quase unânime ao redor do globo como meio de redução de arbitrariedades e promoção da paz ${ }^{2}$, um leigo poderia supor que a maior aderência possível dos agentes públicos aos termos dos textos legais seria uma meta a ser atingida. Não parece, entretanto, ser este o caso. Não pelo menos no Brasil. Como bem salienta Noel Struchner (2009, p. 463), o formalismo jurídico, compreendido como disposição interpretativa de levar a sério a aplicação do texto de uma formulação normativa, "tornou-se um termo 'guarda-chuva', utilizado pelo falante para classificar qualquer sistema jurídico, teoria jurídica, decisão jurídica, ou estilo de pensamento jurídico com o qual não concorda". De fato, tem sido uma tendência na academia pátria a elaboração de doutrinas jurídicas que procuram justificar a adoção de modelos decisórios mais flexíveis em praticamente todos os ramos do Direito ${ }^{3}$, valorizando normas de baixa densidade normativa e técnicas interpretativas mais abertas, como a ponderação.

Há vários motivos concorrentes que parecem justificar esse ceticismo com relação à ideia de aplicação imparcial das razões estatuídas em normas gerais e abstratas a casos concretos $^{4}$, mas especialmente duas explicações são relevantes para a compreensão do

\footnotetext{
${ }^{1}$ Eis a dicção do art. 30: "In the government of this commonwealth, the legislative department shall never exercise the executive and judicial powers, or either of them: the executive shall never exercise the legislative and judicial powers, or either of them: the judicial shall never exercise the legislative and executive powers, or either of them: to the end it may be a government of laws and not of men".

2 A Organização das Nações Unidas (ONU) possui um programa especial de promoção ao respeito ao Estado de Direito em níveis nacional e internacional, sendo esse objetivo uma de suas missões institucionais. Para mais sobre o tema, cf. http://www.un.org/en/ruleoflaw/index.shtml. Acesso em 04/09/2012.

${ }^{3}$ Pode-se citar como exemplos dessa tendência as obras de José Roberto dos Santos Bedaque (2010), na área do Direito Processual, de Luiz Edson Fachin (2006), no Direito Civil, e Adilson Abreu Dalari (2008), no Direito Administrativo. O Neoconstitucionalismo é com certeza uma das principais teorias que se enquadram nesse perfil.

${ }^{4}$ Autores como Manoel Gonçalves Ferreira Filho (2007, p. 41-50) salientam que, no Estado moderno, a irracionalidade na produção legislativa decorrente de uma ausência de identificação entre os cidadãos e os seus representantes em razão de uma midiatização da democracia e a edição de inúmeros decretos legislativos por parte do Executivo faz com que tenhamos não um Estado de Direito, mas um "Estado legal", em que as normas jurídicas não correspondem à vontade geral. Outros autores, como Mangabeira Unger (1983), acreditam que a interpretação judicial nada mais é do que um ato político, condicionado à ideologia de cada intérprete.
} 
desenvolvimento desse movimento acadêmico que acabou desembocando no Neoconstitucionalismo, uma teórica e outra histórica.

A teórica diz respeito às teses defendidas pelo positivismo jurídico que, a despeito de sua ênfase nas fontes do Direito, por almejar ser uma teoria geral e abstrata, nunca enfatizou o processo mediante o qual as normas são criadas em uma sociedade democrática como a brasileira. Muito pelo contrário, positivistas tradicionais, como John Austin ${ }^{5}$, descreviam as normas jurídicas como sendo comandos sancionados pelo soberano. Mesmo Herbert Hart e Hans Kelsen, que formularam uma concepção jurídica em que as normas são criadas por outras normas (e não por um determinado sujeito), jamais tiveram o cuidado de expor o que de especial teria um sistema jurídico construído a partir de um regime democrático. Nesse sentido, as normas foram apresentadas nas principais teorias jurídicas do século $\mathrm{XX}$ dissociadas do contexto político-social no qual elas são criadas e aplicadas, ou seja, o modo como as normas reclamam autoridade e obrigam os cidadãos é apresentado por esses teóricos de maneira similar em qualquer tipo de regime, autoritário ou não. A autonomia das normas jurídicas, fruto do pensamento positivista, faz com que não se percebam os valores a si inerentes, o que contribui para uma atitude de descaso com o texto legal. A imagem que fica é a de que as normas simplesmente estão aí, sendo arbitrário o seu conteúdo.

A histórica se refere ao fato de que durante mais de 20 anos, entre as décadas 1960 e 1980, vivemos sob uma ditadura militar. As leis editadas durante esse período obviamente não refletiam a consciência democrática do povo, sendo associadas como a expressão dos interesses dos agentes no poder. Os opositores da ditadura, portanto, viam as normas jurídicas como instrumento de opressão e de manutenção do status quo. Não por outro motivo, as vertentes de esquerda vinculadas a um pensamento jurídico crítico, como o projeto Direito Achado na Rua ${ }^{6}$, criado na Universidade de Brasília (UnB), defendiam uma atuação dos movimentos sociais contra legem com a finalidade de forçar o reconhecimento dos direitos de atores políticos marginalizados ${ }^{7}$. No contexto de um regime autoritário é compreensível que

\footnotetext{
${ }^{5}$ Cf. o primeiro capítulo da obra de John Austin (1998, p. 9-32), em que o autor caracteriza uma norma jurídica como um comando habitualmente seguido pelos membros da comunidade em razão da ameaça de serem punidos em caso de descumprimento.

${ }^{6}$ De acordo com Alexandre da Costa e José Geraldo da Sousa Júnior (2009, p. 18), o projeto Direito Achado na Rua visa a: "1) determinar o espaço político no qual se desenvolvem as práticas sociais que enunciam direitos ainda que contra legem; 2) definir a natureza jurídica do sujeito coletivo capaz de elaborar um projeto político de transformação social e elaborar a sua representação teórica como sujeito coletivo de direito; 3) enquadrar os dados derivados dessas práticas sociais criadoras de direitos e estabelecer novas categorias jurídicas".

7 No contexto norte-americano, a crítica da esquerda contra o Estado de Direito assumiu feição semelhante, denunciando que o sistema jurídico estaria a privilegiar uma classe poderosa, que, por meio da legalidade, imporia de maneira autoritária os valores do liberalismo e do capitalismo. Nesse sentido, Brian Tamanaha
} 
uma teoria preocupada com a emancipação social afirme que "as palavras da lei não podem funcionar como fontes exclusivas de produção de significação jurídica” ${ }^{\text {. }}$. Essa descrença na capacidade de produzir resultados sociais desejados por meio da legislação é uma herança persistente no imaginário dos juristas pátrios do período da ditadura.

\section{2 - Estado Democrático de Direito e constitucionalismo dirigente}

Como consequência desse ceticismo quanto ao Estado de Direito, adotou-se no Brasil um subterfúgio a esse princípio, o chamado Estado Democrático de Direito. O termo foi inicialmente formulado pelo jurista espanhol Elías Diaz na década de 1960 para designar um terceiro paradigma de Estado vinculado à ideia de democracia socialista.

No entendimento do autor, tanto o Estado liberal de Direito como o Estado Social de Direito falharam na tentativa de construir uma real democracia em virtude das desigualdades econômicas geradas pelo regime econômico capitalista. Enquanto a igualdade formal do Estado liberal teria sido a causa da miséria de grande parte da população, as benesses concedidas pelo Estado de Bem-estar Social não foram suficientes para dirimir as desigualdades materiais entre os cidadãos. A transferência de renda por meio de programas sociais não teria alterado a configuração de poder na sociedade, que continuava nas mãos dos detentores dos fatores de produção. Assim, uma verdadeira democracia dependeria de uma efetiva participação paritária no exercício do poder, o que somente seria possível por meio de uma igualdade de condições socioeconômicas somente alcançável no modelo socialista:

El Estado democrático de Derecho tiene que ser hoy un Estado de estrutura económica socialista: ésta es necessária para la constitución actual de uma verdadera democracia. El neocapitalismo com su famoso Estado del bienestar, apoyándolo todo em uma economia y uma sociedade de consumo no logra, puede decirse, ni superar la enajenación de las masas, ni frenar la desigualdade social, sobre todo a nível internacional. El Estado social de Derecho es, em mi opinión, um Estado insuficientemente democrático. (...) Esta meta, este objetivo que se perfecciona progresivamente la historia es aquí concretado en la fórmula institucional que hemos venido denominado Estado democrático de Derecho, Estado que exige ser construído sobre una

(2004, p. 73-74) explica que: "For the left, too often the law was on the wrong side, showing its authoritarian face, protecting power and privilege, answering peaceful marches and sit ins with angry and national guardsmen brandishing batons, bayonet-mounted rifles, and snapping dogs. For the right, rampant civil disobedience encouraged disrespect for the law and threatened social disorder, to which the law responded meekly and indecisively, reaping further lawlessness. (...) As the radical left saw it, liberalism promised liberty and equality, but instead surreptitiously led to new forms of domination and inequality and cloaked them in legitimacy".

${ }^{8}$ SANTOS; ASSIS, 2010, p. 5899. 
organización económica e ideológica de caráter socialista como forma más correta de llegar a la realización de um auténtica democracia. ${ }^{9}$

Tratava-se de uma ideia política semelhante à de Constituição dirigente, elaborada pelo constitucionalista português José Joaquim Gomes Canotilho, cuja concepção de Constituição vinculava as opções do legislador na direção de um projeto emancipatório de cunho socialista. A desconfiança com relação aos resultados do processo político-majoritário e o ceticismo quanto aos rumos que os detentores do poder poderiam tomar levou à elaboração de um projeto jurídico-doutrinário que se focava na força das normas constitucionais na transformação da sociedade. Buscava-se, com a Constituição dirigente, vincular substancialmente a produção legislativa e o destino do Estado. Em suma, a concepção dirigente de Constituição vislumbrava a Magna Carta como um documento compromissado com certos objetivos políticos que deveriam ser alcançados na arena democrática, subtraindo essas escolhas da seara política ${ }^{10}$.

Analisadas em conjunto, pode-se dizer que as expressões Estado Democrático de Direito e constitucionalismo dirigente são oriundas de um mesmo movimento teórico de desconforto com os resultados da arena democrática. É de se ressaltar, contudo, que ambos os autores formularam suas teorias durante ou logo após períodos de autoritarismo em seus países, o que explica essa suspeição quanto às intenções dos detentores do poder. Na obra de Canotilho, a metáfora da vinculação do legislador serviria como escudo da sociedade contra eventuais desvios de percursos dos agentes públicos no rumo do socialismo, que, à época, se mostrava como a principal via emancipatória.

A disseminação dessas ideias em nossa cultura jurídica reforçou o desprestígio das normas jurídicas, que somente deveriam ser consideradas válidas e exigíveis se condizentes com o projeto político em andamento ${ }^{11}$. Na visão de Canotilho e Elías Diaz, as diretrizes

\footnotetext{
9 DIAZ, 1975, p. 173-178.

${ }^{10}$ Manoel Gonçalves Ferreira Filho (2007, p. 66-67) corrobora esse entendimento, afirmando que: "Na linha de Canotilho, portanto, o Estado de Direito Democrático é aquele que prende o poder político à realização do socialismo. É, sem dúvida, uma concepção que repudia o formalismo do Estado legal; está ela, no entanto, muito distante da ideia de Direito que inspirou o Estado de Direito clássico e que ainda prevalece nas democracias de derivação liberal".

${ }^{11}$ Como bem assevera Gilberto Bercovici (2003, p. 117), “Canotilho vai ter como preocupações centrais em seu trabalho a defesa da não disponibilidade da Constituição pelo legislador e a questão da discricionariedade legislativa. Em suma, o debate sobre o eventual 'excesso de poder legislativo' em virtude da possibilidade dos fins constitucionais serem menosprezados e até substituídos. De acordo com sua proposta, a concretização das 'imposições constitucionais' (normas constitucionais que determinam a realização das tarefas $e$ persecução de fins) é função tanto da legislação, como da direção política. Ou seja, Canotilho procura estabelecer uma vinculação jurídica para os atos políticos na Constituição. A questão das 'imposições constitucionais' não é mera discussão sobre a oportunidade da execução dos dispositivos constitucionais, mas é um problema de cumprimento da Constituição".
} 
constitucionais ganhariam força jurídica vinculante, obrigando todos os poderes constituídos. Cabe ressaltar novamente que se tratava de projetos totalizantes que indicavam o único caminho político a ser adotado pelo Estado, que era o socialismo.

O efeito colateral dessa postura interpretativa de cunho paternalista - pois vinculada a resultados substantivos - foi a explosão de litigiosidade e a proeminência do Poder Judiciário, na medida em que cumpriria a esse órgão estatal, em seu função de dizer o direito válido, a concretização dessa metanarrativa constitucional, ainda que no seu afazer diário fosse necessário suprir a omissão estatal no cumprimento das promessas civilizatórias contidas na Carta Magna, para utilizar a expressão de Daniel Sarmento. Em razão dessa incredulidade com relação aos poderes Legislativo e Executivo, as esperanças restaram todas depositadas no Poder Judiciário, que se tornou responsável pela efetividade da Lei Fundamental. Essa crítica é compartilhada por Gilberto Bercovici:

Em relação ao cumprimento do texto constitucional, um dos problemas desta concepção de Constituição é o fato de que, ao recear deixar a Constituição nas mãos do legislador, a Teoria da Constituição Dirigente acaba relegando a decisão sobre as questões constitucionais ao Judiciário. Como os problemas da Constituição dirigente são, em grande medida, de concretização constitucional, o papel dos órgãos judiciais de controle de constitucionalidade torna-se fundamental, contribuindo, ainda mais, para a despolitização da Constituição. Apesar das críticas de Canotilho ao papel dos tribunais constitucionais na concretização da Constituição dirigente, a observação histórica dá razão à Bockenforde, que afirmou que a Constituição dirigente, ao conter todos os princípios e possibilidades de conformação do ordenamento, favoreceria o crescimento do papel político do tribunal constitucional, que se autoconverteria em "senhor da Constituição" 12 .

Em novo prefácio à sua obra, Canotilho reconheceu a impropriedade de um projeto constitucional compromissório nas democracias constitucionais contemporâneas. A seu ver, "as sociedades modernas pluralistas estruturam-se em termos de complexidade que, longe de assentar na intencionalidade construtiva da política, radica antes na autoorganização (...) sendo irrealista tentar através de um código unitarizante dos vários sistemas sociais dirigir constitucionalmente a sociedade ${ }^{13}$ ". Nesse contexto, o respeito à diversidade de perspectivas

\footnotetext{
${ }^{12}$ BERCOVICI, 2003, p. 118.

${ }^{13}$ CANOTILHO, 2001, p. xxvi. Em outra passagem, Canotilho (2001, p. x) deixa claro que: “As constituições dirigentes, entendidas como constituições programático-estatais, não padecem apenas de um pecado original - o da má utopia do sujeito prejectante. Como dissemos, elas ergueram o Estado a 〈homem de direção> exclusiva ou quase exclusiva da sociedade e converteram o direito em instrumento funcional nessa direção. Desse modo, o Estado e o direito são ambos arrastados para uma crise política regulativa. Por um lado, erguer o Estado a <homem de direção> implica o desconhecimento do alto grau de diferenciação da estatalidade pluralisticamente organizada".
} 
que marca nossa sociedade atual exige a neutralização de qualquer discurso totalizante, como o da Constituição dirigente, para possibilitar o reencontro da política com o direito constitucional. A revalorização da lei e da noção de Estado de Direito se apresenta como passo necessário nesse processo.

Não obstante essas novas considerações do jurista português, a assimilação de suas ideias originárias foi tão profunda em nosso contexto acadêmico que atualmente há muita confusão na utilização do termo Estado Democrático de Direito pelos autores nacionais, que continuam com a retórica emancipatória para justificar a existência do ordenamento jurídico. A definição de José Afonso da Silva (2007, p. 119, grifo nosso) é um ótimo exemplo dessa perspectiva. Ao comentar o art. $1^{\text {o }}$ da Constituição Federal de 1988, o autor afirma que " $a$ configuração do Estado Democrático de Direito não significa apenas unir formalmente os conceitos de Estado Democrático e Estado de Direito", mas consubstancia-se "na criação de um conceito novo, que leva em conta os conceitos dos elementos componentes, mas os supera na medida em que incorpora um componente revolucionário de transformação do status quo".

De maneira semelhante, José Carlos Francisco (2011, p. 419) conceitua o Estado Democrático de Direito como "o modelo de organização mais aparelhado para a concretização da justiça social, pois a Constituição fixa metas em normas programáticas a serem implementadas". Veja que ambos os autores formulam definições compromissadas com o avanço de certos resultados. A lei, nesse sentido, torna-se dependente de um modelo ideal de Estado, o que gera insegurança jurídica aos cidadãos que devem se questionar a todo instante se as normas que regulam uma situação da vida são compatíveis com o projeto de mudança social.

Ao que tudo indica, o Neoconstitucionalismo surge como uma proposta teórica descendente das ideias de constitucionalismo dirigente e de Estado Democrático de Direito, o que pode ser percebido através da similitude das propostas ${ }^{14}$. No âmago dessas teorias há uma forte tendência de utilizar o Direito, notadamente a interpretação constitucional, como instrumento de transformação social ${ }^{15}$. É possível inclusive traçar um paralelismo entre o

\footnotetext{
${ }^{14} \mathrm{O}$ vínculo entre o Neoconstitucionalismo e o constitucionalismo dirigente torna-se mais claro na obra de Lênio Luiz Streck (2009a, p. 207) que de maneira expressa entende o Neoconstitucionalismo como "o constitucionalismo compromissório, dirigente e principiológico”.

${ }^{15}$ Essa conclusão é compartilhada por Gilberto Bercovici (2004, p. 12-13), para quem: "a Teoria da Constituição Dirigente, a Constituição não é só garantia do existente, mas também um programa para o futuro. Ao fornecer linhas de atuação para a política, sem substituí-la, destaca a interdependência entre Estado e sociedade: a Constituição Dirigente é uma Constituição estatal e social. No fundo, a concepção de Constituição Dirigente para Canotilho está ligada à defesa da mudança da realidade pelo direito. $O$ sentido, o objetivo da Constituição Dirigente é o de dar força e substrato jurídico para mudança social".
} 
fenômeno da constitucionalização do direito e o programa econômico-social expansivo do constitucionalismo compromissório. O resultado de ambas as atitudes é uma desvalorização das normas jurídicas, que passam a ter sua validade condicionada à concretização das metas políticas almejadas pelo intérprete, incitando o desrespeito às prescrições legais.

A construção de uma concepção jurídica que implique respeito às leis exige uma reelaboração valorativa do conceito do Estado de Direito a partir do contexto concreto das sociedades democráticas contemporâneas, abandonando-se os preconceitos inerentes ao positivismo jurídico e ao regime jurídico autoritário do passado. O Estado de Direito, portanto, somente se mostrará um ideal atrativo caso se recupere a ideia de dignidade da legislação. Esse é o tema dos próximos dois tópicos.

\section{3 - Estado de Direito e democracia}

As leis não resultam do acaso. O anteprojeto de novo Código Penal brasileiro, por exemplo, mesmo tendo sido elaborado após várias audiências públicas no Senado Federal, vem sofrendo severas críticas de renomados juristas ${ }^{16}$. O Congresso Nacional, ao deliberar acerca do novel códex, levará em consideração os mais diversos pontos de vista antes de decidir em nome da sociedade quais condutas serão punidas e qual a intensidade das penas. Ademais, o Código de Defesa do Consumidor ${ }^{17}$, o Estatuto da Criança e do Adolescente ${ }^{18}$, o Estatuto do Idoso $^{19}$, o Estatuto da Igualdade Racial ${ }^{20}$, a lei da Ficha Limpa ${ }^{21}$ e a lei que reserva $50 \%$ das vagas em universidades federais para alunos de escolas públicas ${ }^{22}$, atos normativos editados com claro intuito progressista, também não podem ser taxados de arbitrários. A criminalização e o endurecimento das sanções administrativas para aqueles que dirigem veículos automotores sob a influência de bebidas alcoólicas com a chamada Lei

\footnotetext{
${ }^{16}$ Cf., nesse sentido, o debate travado pela revista eletrônica Consultor Jurídico entre o Professor Titular de Direito Penal da Universidade de São Paulo Miguel Reale Júnior (2012) - classificando a proposta como uma "obscenidade", pois conteria "erros da maior gravidade técnica e da maior gravidade com relação à criação dos tipos penais, de proporcionalidade" - e o Professor Luiz Carlos dos Santos Gonçalves (2012), membro da comissão de juristas encarregada de elaborar o anteprojeto, que afirma que o documento encaminhado ao Senado Federal é resultado de um debate amplo e público realizado no âmbito de uma comissão plural que tomou suas decisões por meio do voto majoritário de seus membros em audiências públicas transmitidas ao vivo pela TV Senado. Independentemente do mérito das críticas do Professor Miguel Reale Júnior, o que se percebe é que a academia e os políticos estão bastante atentos às escolhas que estão sendo tomadas, sendo absolutamente equivocado afirmar que tais opções são arbitrárias ou destituídas de racionalidade.

17 Brasil. Lei no ${ }^{\circ}$ 8.078, de 11 de setembro de 1990.

18 Brasil. Lei no ${ }^{\circ}$. 8.069, de 13 de julho de 1990.

19 Brasil. Lei $\mathrm{n}^{\mathrm{o}} 10.741$, de $1^{\circ}$ de outubro de 2003.

${ }^{20}$ Brasil. Lei no ${ }^{\circ}$ 12.288, de 20 de julho de 2010.

21 Brasil. Lei complementar $n^{\circ} .135$, de 4 de junho de 2010.

22 Brasil. Lei no . 12.711, de 28 de agosto de 2012.
} 
$S e c a^{23}$ é outro bom exemplo de legislação aprovada com o intuito deliberado de modificar a cultura da população com vistas a produzir resultados sociais positivos ${ }^{24}$.

É digno de nota, também, o intenso debate político gerado em torno da aprovação do chamado Código Florestal. Após sofrerem diversas derrotas políticas na última década em razão dos programas de reforma agrária e de proteção das comunidades indígenas e quilombolas, os produtores rurais elegeram uma grande bancada parlamentar para defender seus interesses, o que levou a uma derrota política do Poder Executivo em aprovar dispositivos legais mais protetivos ao meio ambiente ${ }^{25}$. Esses exemplos demonstram que o resultado da atividade legislativa no Brasil não pode ser considerado viciado. Não há, a priori, oprimidos e opressores, mas argumentos vencidos e vencedores, a depender da conjuntura política.

Não se está argumentando que o processo político brasileiro seja perfeito. As denúncias apuradas no bojo do chamado processo do Mensalão ${ }^{26}$ - de que o Poder Executivo teria subornado parlamentares com pagamentos mensais para que votassem a favor do governo durante o primeiro mandato do Presidente Lula - são provas concretas de que ainda há muito a ser feito em prol de nossa democracia. Há de se ter em mente que o Poder Judiciário também não está imune a desvios de condutas por parte de seus membros. Basta observar que, desde a criação do Conselho Nacional de Justiça, em dezembro de 2004, 49 magistrados foram punidos por esse órgão de controle externo do Poder Judiciário ${ }^{27}$. Tais fatos, contudo, não apontam para uma crise ou esgotamento de nossas instituições republicanas. Por mais graves que se apresentem, seria equivocado comparar o atual regime político pátrio com o que ocorre em países autoritários, seja na criação ou na aplicação das leis. Em termos gerias, pode-se dizer que temos um regime democrático em bom funcionamento ${ }^{28}$.

${ }^{23}$ Brasil. Lei $\mathrm{n}^{\circ} .11 .705$, de 19 de junho de 2008.

${ }^{24}$ É importante ressaltar a esse respeito que o alcance da lei foi drasticamente reduzido em razão de decisão do Superior Tribunal de Justiça considerando somente o bafômetro e o exame de sangue como provas válidas para comprovar a embriaguez do motorista. Cf. Superior Tribunal de Justiça, Recurso Especial $\mathrm{n}^{\mathrm{o}}$. 1.111.566DF, Min. Rel. Marco Aurélio Bellizze, julgado em 28/03/2012, acórdão publicado no DJ-e de 04/09/2012.

${ }^{25}$ Sobre o crescimento da bancada ruralista, cf. a radiografia das eleições de 2010 realizada pelo Departamento Intersindical de Assessoria Parlamentar (DIAP), disponível em http://www.diap.org.br/index.php?option=com content\&view=article\&id=15500:bancada-ruralista-aumentacom-o-reforco-de-novos-parlamentares\&catid=45:agencia-diap\&Itemid=300. Acesso em 08/09/2012.

26 Supremo Tribunal Federal, Ação Penal no . 470, Min. Rel. Joaquim Barbosa, julgamento iniciado em 03/08/12, ainda pendente de resultado.

${ }^{27}$ Sobre o assunto, cf. matéria publicada na Revista Consultor Jurídico em 29 de dezembro de 2011 disponível em http://www.conjur.com.br/2011-dez-29/sete-anos-atuacao-cnj-contabiliza-49-magistrados-punidos. Acesso em 08/09/2012.

${ }^{28}$ Essas conclusões são compartilhadas por Luís Roberto Barroso (2008a, p. 17), para quem: “A Constituição de 1988 é o símbolo maior de uma história de sucesso: a transição de um Estado autoritário, intolerante e 
Em circunstâncias tais, é no mínimo curioso que ainda hoje haja uma descrença generalizada pela observância da lei no Brasil. Isso porque o desrespeito pelas normas jurídicas simboliza, em última análise, desprezo pela própria democracia. Há uma moralidade intrínseca na forma como se administra a vida de uma sociedade plural por meio de um ordenamento jurídico que precisa ser resgatada pela dogmática constitucional. Como bem assevera Jeremy Waldron, revela-se necessário desenvolver uma "teoria jurídica que exponha o modo como o Direito se apresenta em democracias, em contraste com o Direito das monarquias, ditaduras e assim por diante", explorando "as conexões e consiliências entre o valor da democracia e o conceito de Direito" ${ }^{29}$.

O desafio posto por Waldron é refletir sobre o que representa o Estado de Direito em uma sociedade que considera a política majoritária como forma legítima de tomada de decisões coletivas. A legislação, resultado de um processo deliberativo em que os diversos pontos de vista são representados, apresenta-se, nas democracias contemporâneas, como o único medium em que as inúmeras identidades dos sujeitos podem ser unificadas de maneira não arbitrária. É através das normas jurídicas que a comunidade de princípios se personifica, e não por meio de um metadiscurso ideológico que tente minimizar o fato de que há inúmeros desacordos na sociedade. Esse ponto merece um maior aprofundamento.

\section{4 - Desacordos, regra da maioria e Estado de Direito: a dignidade da legislação}

As sociedades modernas são marcadas pela pluralidade de perspectivas sobre o que deve ser considerado justo ${ }^{30}$. Não há consenso sobre os mais diversos temas relevantes para a

muitas vezes violento para um Estado democrático de direito. Sob sua vigência, realizaram-se cinco eleições presidenciais, por voto direto, secreto e universal, com debate público amplo, participação popular e alternância de partidos políticos no poder. Mais que tudo, a Constituição assegurou ao país duas décadas de estabilidade institucional. E não foram tempos banais. Ao longo desse período, diversos episódios deflagraram crises que, em outros tempos, dificilmente teriam deixado de levar à ruptura institucional. $O$ mais grave deles terá sido a destituição, por impeachment, do primeiro presidente eleito após a ditadura militar, sob acusações de corrupção. Mas houve outros, que trouxeram dramáticos abalos ao Poder Legislativo, como o escândalo envolvendo a elaboração do Orçamento, a violação de sigilo do painel eletrônico de votação e o episódio que ficou conhecido como 'mensalão'. Mesmo nessas conjunturas, jamais se cogitou de qualquer solução que não fosse o respeito à legalidade constitucional. Não há como deixar de celebrar o amadurecimento institucional brasileiro".

29 Tradução livre de WALDRON, 2008-2009, p. 679-681.

30 As ideias desse tópico são basicamente extraídas dos livros Law and Disagreement e Dignidade da Legislação, ambos de Jeremy Waldron. Waldron (1999, p. 1) exemplifica esses desacordos da seguinte forma: "We disagree about what we owe each other in the way of tolerance, forbearance, respect, co-operation, and mutual aid. Liberals disagree with conservatives; socialists disagree with market economists; the party of freedom disagrees with the party of community and both disagree with the party of equality; feminists disagree with those who want the government to stand up for 'family values'; last-ditch defenders of the welfare state disagree with triumphant opponents of taxation; and pragmatists and utilitarians disagree with those who think the task of law is to vindicate the claims or order, retribution, and desert". 
população - seja sobre questões menores, como a possibilidade de se identificar salas de aula em universidades públicas com o nome de grandes doadores, ou sobre questões mais amplas, como a reserva de cotas sociais no ensino público universitário - de maneira tal que sempre haverá situações em que um determinado cidadão considerará o arranjo institucional estabelecido injusto ou inadequado.

De fato, a inexistência de uma doutrina abrangente ${ }^{31}$ compartilhada faz com que toda ação estatal desagrade parcela da população que discorda de seu conteúdo. Mesmo em questões de princípio - que possuem pretensão de universalidade, portanto - há desacordos morais infindáveis. Filósofos como Ronald Dworkin, John Rawls e Robert Nozick, que adotam posições não utilitaristas, discordam sobre quais direitos realmente devem ser considerados fundamentais em uma sociedade justa ${ }^{32}$. O aborto deve ser legalizado? O suicídio assistido é um direito de um paciente em estado terminal? Não há consenso sobre essas questões e não há nada na natureza humana que indique que essas disputas serão definitivamente equalizadas. A ideia de desacordo é ubíqua e não há como escapar dessa realidade dividida ${ }^{33}$. Em suma, inexiste uma fonte confiável que possa ser consultada para responder aos dilemas morais que exsurgem no dia a dia.

Não obstante essa diversidade de perspectivas, a vida em sociedade exige que vários atos sejam praticados de maneira coletiva. A criação de uma rede pública de ensino ou a implantação de uma malha ferroviária, por exemplo, são projetos que não são possíveis sem o

31 O termo "doutrina abrangente" é utilizado por John Rawls (2003, p. 19) para designar doutrinas religiosas, filosóficas ou morais que se aplicam a todos os temas e abarque todos os valores e que, portanto, imporia uma determinada concepção de justiça como sendo a única verdadeira ou aceitável. Para Rawls, em uma sociedade plural, uma teoria de justiça não pode ser entendida como uma aplicação de uma doutrina desse tipo à estrutura básica da sociedade.

32 Esses são autores mencionados por Waldron (1999, p. 211). Esse ponto talvez seja fundamental para a exata compreensão da concepção waldroniana acerca da função do Legislativo se comparado com a teoria de Ronald Dworkin. Como já visto, Dworkin faz uma distinção entre argumentos de princípio e de política a fim de demarcar a linha divisória entre uma decisão judicial legítima e uma ilegítima. Argumentos de política são inerentes ao debate sobre como os bens devem ser distribuídos em uma sociedade bem-ordenada. John Rawls, por exemplo, desenvolve sua teoria de justiça buscando responder a esse questionamento. Dworkin, ciente dos desacordos existentes na sociedade sobre esse tópico, entende que essa questão deva ser respondida pelo legislador, não pelo Judiciário. Já argumentos de princípio dizem respeito à forma como tratamos os semelhantes, respondendo sobre como devemos agir para tratar o outro com igual respeito e consideração. É algo relacionado diretamente com a dignidade da pessoa, com o seu reconhecimento enquanto pessoa, não com a distribuição de bens materiais. Para Dworkin, essa é uma questão moral e que, por isso, possui uma resposta correta relacionada ao reconhecimento universal de direitos. Os juízes teriam legitimidade para decidir questões morais - e não de justiça - em razão de já haver o reconhecimento desses princípios na Constituição, daí a expressão leitura moral da Constituição. O que Jeremy Waldron tenta enfatizar em sua teoria do direito é que, mesmo nas questões de princípio, há desacordos morais persistentes na sociedade sobre sua extensão e significado. Assim, Waldron vai mais além, afirmando que nem mesmo as questões de princípio, ou seja, de direitos, deveriam ser decididas pelos tribunais, mas pelo Legislativo, o que não significa, por outro lado, que o autor abandona a ideia de direitos, conforme se verá a seguir.

33 O filósofo moral Alastair MacIntrye (1999, p. 76) assevera, nesse sentido, que "no fact seems to be plainer in the modern world than the extent and depth of moral disagreement, often enough disagreement on basic issues". 
envolvimento de inúmeras pessoas que não necessariamente estão de acordo com as políticas públicas adotadas. De forma semelhante, leis que proíbam a poligamia ou o jogo do bicho são medidas editadas em nome de todos, mesmo que não haja unanimidade sobre esses temas. A necessidade de se decidir uma série de questões em nome da coletividade em uma situação de dissenso generalizado é o que Jeremy Waldron (1999, p. 102) denomina circunstâncias da política $^{34}$. Na ausência de acordos substantivos perenes, o desafio que se coloca é encontrar um procedimento decisório no qual as pessoas não se sintam desrespeitadas caso suas visões não prevaleçam ao final. A questão a ser respondida é como, na perspectiva do cidadão, entender legítimas opções estatais consideradas por ele equivocadas?

Para Waldron, somente quando os cidadãos são tratados com dignidade é que se torna possível estabelecer uma agenda comum considerada legítima, a despeito da existência dos inúmeros desacordos ${ }^{35}$. Nesse sentido, dignidade significa reconhecer que cada sujeito é capaz de refletir sobre as implicações morais de suas opções a partir da perspectiva do outro, discernindo o que é certo do que é errado, o justo do injusto, transcendendo os interesses meramente pessoais. Um sujeito autônomo e independente tem condições intelectuais para deliberar de maneira responsável sobre o seu futuro e sobre o futuro de sua comunidade, sentindo-se moralmente constrangido por seus atos e compromissos assumidos. Ou seja, a dignidade envolve senso de responsabilidade pelas decisões alcançadas. Tratar alguém com distinção é reconhecer a pessoa como portadora de direitos ${ }^{36}$, e não como mero objeto passível de manipulação. Quando todas se reconhecem dignas de consideração, surge a obrigação de respeito mútuo, o que implica a impossibilidade de se impor uma determinada perspectiva sobre o outro. O consentimento é o meio pelo qual pessoas obtêm a permissão para agir em nome do outro. Os mais variados pontos de vista - entendidos como resultados de uma reflexão moral por parte do cidadão - devem ser igualmente considerados relevantes, não havendo nada a priori que indique a superioridade de uma ou de outra visão de mundo.

\footnotetext{
${ }^{34}$ Como bem explica Waldron (2003, p. 187), “a discordância não teria importância se as pessoas não preferissem uma decisão comum, e a necessidade de uma decisão comum não daria origem à política como a conhecemos se não houvesse pelo menos o potencial para a discordância quanto à qual deve ser a decisão comum. Nessa exposição, imaginar eliminada a persistência da discordância é como desejar eliminada a escassez em qualquer exposição da justiça distributiva".

35 Segundo Waldron (2003, p. 186), "a perspectiva de persistir a discordância deve ser considerada, penso, como uma das condições elementares da política moderna. Nada do que fazemos na política faz muito sentido se procedemos sem levar essa condição em conta".

36 Sobre a relação entre ser titular de direitos e ter capacidade para deliberar moralmente, explica Waldron (1999, p. 282): “The identification of someone as a right-bearer expresses a measure of confidence in that person's moral capacities - in particular his capacity to think responsibly in about the moral relation between his interests and the interests of others. The possession of this capacity - a sense of justice, if you like - is the primary basis of democracy competence. Our conviction that ordinary men and women have what it takes to participate responsibly in the government of their society is, in fact, the same conviction as that on which the attribution of rights is based".
} 
Nas sociedades contemporâneas, inúmeras questões necessitam ser decididas tratando de temas de fundamental importância sobre os quais não há consenso. Em regimes não autoritários, o pluralismo gera um grave problema de coordenação que não pode ser simplesmente minimizado por meio de doutrinas que pretendam oferecer uma metanarrativa abrangente. Se as pessoas não concordam sobre o que é justo, não há uma teoria da justiça que possa ser consultada. É necessário elaborar uma teoria da autoridade adaptada a uma sociedade permeada por desacordos. Para Waldron, tendo-se em vista a impossibilidade de se estabelecer um acordo de resultados, torna-se necessário obter o consentimento ex ante dos cidadãos para que atos potencialmente contrários às suas convicções sejam editados em nome da coletividade, o que somente é possível por meio de um processo político majoritário ${ }^{37}$ :

É porque discordamos quanto ao que deve ser considerado como resultado substantivamente respeitoso que precisamos de um processo decisório; neste contexto, recolocar a substância no processo irá necessariamente privilegiar uma opinião controvertida sobre o que o respeito acarreta e, portanto, deixar de respeitar as outras. Assim, nas circunstâncias da política, tudo com que podemos trabalhar é a "compreensão implausivelmente estreita" do igual respeito; [...] a decisão majoritária é o único processo decisório compatível com o igual respeito nesse sentido necessariamente empobrecido ${ }^{38}$.

A lógica do raciocínio é a de que os cidadãos somente podem ser tratados com igual respeito e consideração caso tenham condições de produzir igual impacto nas decisões coletivas. Caso contrário, estar-se-ia admitindo haver pontos de vista mais importantes, distinguindo os sujeitos em diferentes classes a depender de seu status. A regra da maioria é a única forma de decisão na qual se torna possível levar em consideração todas as diversas perspectivas sem discriminação. A política democrática definida como processo mediante o qual o agir coletivo é definido por meio de votação majoritária dos envolvidos consegue dar conta dos desacordos existentes nas sociedades contemporâneas sem que haja a imposição autoritária de uma solução. Somente por meio da participação política é que o problema da legitimidade pode ser resolvido, razão pela qual o direito à participação é considerado por

\footnotetext{
${ }^{37}$ O processo majoritário é assim qualificado por Waldron (2003, p. 192): “A decisão majoritária não é apenas um processo decisório eficaz, é um processo respeitoso. Respeita os indivíduos de duas maneiras. Primeiro, respeita e considera seriamente a realidade de suas diferenças de opinião quanto à justificação e ao bem comum. A decisão majoritária não requer que a opinião de ninguém seja menosprezada ou silenciada por causa da importância imaginada do consenso. Ao impor o nosso apoio e o nosso respeito ela não exige que nenhum de nós finja haver um consenso quando não há, meramente porque pensamos que deveria haverquer porque qualquer consenso é melhor do que nenhum, quer porque a visão que impressiona alguns de nós como correta parece tão evidentemente correta por si que não conseguimos imaginar como alguém poderia sustentar o contrário".

${ }^{38}$ WALDRON, 2003, p. 197.
} 
Waldron (1999, p. 232-254) como o direito dos direitos. Três pontos merecem uma qualificação antes de se analisar a legitimidade das assembleias como casas deliberativas.

O primeiro se refere à ideia de tirania da maioria, que normalmente surge em contextos de discussão acerca do direito legislado. Inicialmente é preciso esclarecer que a mera opinião pessoal de que algo deveria ser considerado direito não faz com que sua negação seja algo tirânico. Caso isso fosse verdade, não haveria como coordenar a vida em coletividade, pois cada um demandaria direitos que outros não reconhecem ${ }^{39}$. A mera derrota em uma batalha política não pode significar opressão da minoria sob pena de minar o próprio projeto coletivo. Tirania haveria se as pessoas fossem obrigadas a aceitar um ponto de vista do qual não tenham tido a oportunidade de participar de sua formação ou se sistematicamente saíssem vencidas nas votações, o que nos leva ao segundo ponto.

Um dos temores associados com a elaboração de leis por maiorias políticas se refere à possibilidade de que se forme uma facção dominante que explore os demais membros da sociedade. Esse raciocínio parte do pressuposto de que as pessoas se reunirão não para discutir o bem comum, mas para defender seus interesses primários, utilizando-se de um agir estratégico. Tal modelo argumentativo encontra-se em contradição com a ideia de conferir direitos aos cidadãos, que, conforme visto acima, parte do pressuposto que as pessoas possuem capacidade para refletir moralmente e discernir o que é certo e errado, o que pressupõe que elas, ao se reunirem para deliberar sobre o futuro da sociedade, agirão de boa$\mathrm{fé}^{40}$. Do ponto de vista normativo, não há motivos para se desconfiar das intenções dos políticos, da mesma forma como não há porque desacreditar nos desígnios do juiz Hércules, ainda que na prática haja contraexemplos nas duas esferas ${ }^{41}$.

\footnotetext{
${ }^{39}$ Nesse sentido, Waldron (1999, p. 13) afirma: "The point to remember here is that nothing tyrannical happens to me merely by virtue of the fact that my opinion is not acted upon by a community of which I am a member. Provided that the opinion which is acted upon takes my interests, along with everyone's properly into account, the fact that it is not my opinion is not itself a threat to my freedom or well-being".

40 O ponto é assim esclarecido por Waldron (1999, p. 304): "My argument has proceeded on the premise that democratic politics need not to be like that [self-interested], and that it is in fact much less like that than the denigrators of popular majoritarianism tend to claim. I have insisted too that we should resist the temptation to say that it is like that simply because we find ourselves contradicted or outvoted on some matter of principle. We do not need to invoke self-interest to explain disagreements about rights, for it is sufficiently explained by the difficult of the subject-matter and by what John Rawls called 'the burdens of judgment'. If we ascribe someone's political difference with us to the influence of self-interest, that must be justified as a special explanation, over and above the normal explanation of human disagreement about complex questions".

41 Os exemplos de leis com intuito progressista citados no início deste tópico parece ser uma clara indicação que os legisladores brasileiros não agem de maneira a manter os privilégios de uma maioria em detrimento de uma minoria. Ao contrário, parecem comprovar que há muito trabalho sério sendo realizado. Some-se a isso o fato de que dificilmente o Congresso Nacional aprova leis que sejam absolutamente contrárias aos direitos fundamentais. Normalmente o que se discute nos questionamentos da inconstitucionalidade é qual concepção de direitos é a mais correta. Nesse diapasão, Waldron (1999, p. 287-291) questiona se o controle de constitucionalidade nas democracias contemporâneas estáveis produziriam melhores resultados do que o
} 
O terceiro e último ponto também se relaciona à ideia de direitos. A defesa da regra da maioria não implica a adoção do utilitarismo ou do ceticismo moral. Pelo contrário, a confiança no processo democrático como meio de se decidir questões socialmente relevantes parte do pressuposto de que os cidadãos são plenamente capazes de refletir moralmente e que, por isso, merecem que seus pontos de vista sejam igualmente levados em consideração. $\mathrm{O}$ desconforto com essa forma de deliberação pública, por outro lado, é que parece estar em contradição com a ideia de reconhecimento de direitos, pois torna a realização da justiça dependente da imposição paternalística de alguém de fora, sejam juízes ou filósofos, que supostamente estariam em melhores condições para ditar os rumos da sociedade. Ou seja, as alternativas à regra da maioria é que refletem, ainda que de maneira oculta, o ceticismo quanto à capacidade deliberativa dos cidadãos, além de apresentarem uma inegável faceta autoritária $^{42}$.

Esclarecidos esses pontos, cumpre finalmente apontar alguns aspectos inerentes à produção normativa em legislaturas que fazem com que o direito legislado seja considerado legítimo do ponto de vista democrático. Tal esforço se justifica em razão do preconceito que existe quanto ao Poder Legislativo. Com efeito, as assembleias são por vezes caracterizadas como uma forma irracional de se produzir normas quando contrastadas com a forma cautelosa na qual os juízes fundamentam seus casos. A grande quantidade de parlamentares e a apuração do resultado por meio do voto da maioria são consideradas características desprezíveis. Ocorre que para os fins de um direito democrático, as assembleias apresentamse muito mais propensas a gerar resultados legítimos. De fato, a existência de centenas de membros nas legislaturas representa que os interesses dos cidadãos são variados, e não homogêneos. Essa multiplicidade de perspectivas é a forma como os argumentos antagônicos

processo político majoritário no que concerne à proteção de direitos fundamentais, concluindo que a resposta a tal questionamento não é tão óbvia nem de fácil verificação, já que nem mesmo é possível se chegar a um acordo sobre quais resultados são desejáveis (caso contrário haveria uma teoria de justiça amplamente compartilhada).

${ }^{42}$ Waldron (2003, p. 76), baseado na filosofia política de Kant, explica a relação entre a posição moral das pessoas que discordam sobre um tema e a forma como a imposição de uma visão unilateral seria equivocada: "Mas, na transição da filosofia moral para a filosofia política, Kant insiste em que agora nos demos conta do fato de que há outros no mundo além de nós. E insiste em que devemos ver os outros não apenas como objetos de interesse ou respeito moral, mas como outras mentes, outros intelectos, outros agentes de pensamento moral, coordenados e em competição com os nossos. Quando penso em justiça, devo reconhecer que os outros estão pensando em justiça e que a minha confiança na qualidade objetiva das minhas conclusões corresponde à confiança deles na qualidade objetiva das suas. (...) Se há, porém, razões para pensar que a sociedade precisa de apenas uma visão de certa questão específica à qual todos devem dar preferência, pelo menos no que diz respeito a suas interações externas, então, deve haver uma maneira de identificar uma visão como a visão da comunidade e um fundamento para a nossa fidelidade a ela não baseado em nenhum juízo que tivéssemos que fazer quanto a sua retidão”. 
dispersos na sociedade são oficialmente representados. Assim, o número elevado de membros deve ser considerado um ponto positivo das legislaturas.

Além disso, afirmar que o processo político se reduz à contagem dos votos de seus membros não é um retrato fidedigno da atividade parlamentar. Há uma série de debates em comissões nas quais os projetos são analisados e discutidos. Emendas são feitas, votações são refeitas, sugestões são acatadas e propostas indeferidas. Nesse trâmite há uma interação intensa entre os parlamentares que procuram chegar a um acordo, mesmo não havendo um consenso sobre o tema. Isso sem contar que em um sistema bicameral, como o do Congresso Nacional brasileiro, a proposta necessariamente tem que ser acatada no mínimo duas vezes.

Antes de se colocar um assunto definitivamente em pauta para votação, presume-se que já houve suficiente debate em que os diferentes posicionamentos que simbolizam a pluralidade de perspectivas foram confrontados em público. Como bem salienta Waldron (2003, p. 109), "é na legislatura que nossos representantes discutem sobre a justiça; é na legislatura que discordamos sobre a justiça, onde temos segundos pensamentos sobre a justiça, onde revemos o nosso senso de justiça e nos atualizamos".

O complicado trâmite interno nas casas legislativas chama a atenção para outro ponto muitas vezes relegado pelos teóricos adeptos de uma interpretação judicial mais criativa: o texto da norma tem que ser levado a sério por dois motivos especiais. Primeiro, por ter sido com relação àquela proposta canônica de lei que os representantes conseguiram chegar a um acordo. A forma de determinada cláusula legal é cuidadosamente cunhada com vistas a obter o apoio necessário para sua aprovação. Qualquer alteração em sua estrutura poderia ter levado à sua rejeição. Em uma sociedade marcada pelo pluralismo, o fato de ter-se chegado a um acordo para a aprovação de determinada norma torna o seu texto relevante na aplicação jurídica ${ }^{43}$. Segundo, é através do texto legal que os parlamentares procuram tornar acessíveis ao público em geral os termos nos quais restou estabelecido o acordo político ${ }^{44}$. Assim, as expressões linguísticas utilizadas na confecção da norma jurídica não podem ser entendidas como aleatórias, mas propositadamente talhadas com o fim de possibilitar a coordenação de condutas com fidelidade ao acordo firmado.

\footnotetext{
${ }^{43}$ De acordo com Waldron (1999, p. 25): "I suspect the answer has to do with the sort of institution that a legislature is: a large gathering of disparate individuals who purport to act collectively in the name of the whole community, but who can never be sure exactly what is they have settle on, as collective body, except by reference to a given form of words in front of them".

44 Eis a explicação de Waldron (1999, p. 82-82) sobre esse ponto: "To the extent that law makes use of specific verbal formulations, it seeks to connect and associate itself as a social institution with another institutionthe institution of natural language. In particular, it seeks to associate itself with whatever interpersonal determinacy there may be in natural-language communication".
} 
Percebe-se, pois, que a legislação, fruto do processo democrático, revela-se como o medium pelo qual se torna possível a coordenação das condutas em uma sociedade marcada por um pervasivo dissenso. Os cidadãos resignam-se ao deparar com normas jurídicas contrárias à sua convicção por compreender (i) que inexiste consenso sobre o tema e (ii) que a política majoritária é o único meio legítimo para se decidir essas questões. Uma vez editada uma lei, sua observância e implementação se transfere para a esfera da prática social ${ }^{45}$.

O ideal do Estado de Direito se refere exatamente ao tratamento dispensado aos cidadãos na utilização dessas normas jurídicas como parâmetros de conduta. De nada adiantaria haver um acordo legítimo sobre como tratar determinado tema se na efetivação desse compromisso seu teor fosse modificado ${ }^{46}$. Em suma, o modo como as normas são utilizadas no gerenciamento da vida em coletividade revela-se relevante para fins de aferição da legitimidade de determinado regime jurídico. O que significar estar sob o auspício de normas? Como tratar dignamente os cidadãos na aplicação das leis? O próximo capítulo será dedicado à análise dos elementos e valores inerentes ao Estado de Direito.

\footnotetext{
${ }^{45}$ Waldron defende que os direitos estarão mais bem protegidos pelos parlamentos em razão de duas características específicas desses órgãos: i) o número elevado de parlamentares que devem representar os variados posicionamentos na sociedade; ii) o voto majoritário que permite, após um robusto debate entre os vários membros, chegar-se a uma decisão que respeite cada participante com igual respeito, inclusive os perdedores que continuam a discordar da posição adotada, considerando todos como contribuintes valorosos para o debate, ao invés de ignorantes ou excluídos em razão de preconceito. Isso não significa que caso essas instituições não funcionem dessa maneira, deva-se insistir na defesa do processo político como locus adequado para a defesa de direitos. Em livro recente, Waldron, ao criticar o modelo neozelandês, deixa claro que a regra da maioria não é suficiente para que não haja uma Corte Constitucional, argumentando em favor da adoção do bicameralismo e da criação de procedimentos deliberativos que forcem os membros do Legislativo a produzir um genuíno debate sobre os temas das legislações, e não apenas chancelem uma decisão previamente tomada pelo Poder Executivo, como medidas para sanear o sistema político de seu país natal. Cf. WALDRON, 2008a.

46 Oscar Vilhena Vieira (2008, p. 204), apoiado em Rousseau, explica essa necessidade de tratamento respeitoso na aplicação das normas como condição do Estado de Direito de maneira similar: "Neste sentido, é importante enfatizar que a justiça procedimental não está limitada a processos para edição de leis gerais, o que seria aceito por todos os participantes no processo político, mas também trata da maneira pela qual essas leis são implementadas pelo Estado. (...) Dessa maneira, a justiça da aplicação das leis é tão importante quanto a justiça referente a sua produção. Se a aplicação do direito não for levada a cabo com imparcialidade, de acordo com parâmetros de devido processo apresentados pela própria lei, o Estado de Direito perderá sua autoridade e, consequentemente, o povo não o verá como uma diretriz aceitável para a sua ação".
} 


\section{Capítulo 6 - A dignidade do Estado de Direito}

\section{1 - Três temas associados ao Estado de Direito}

No último capítulo, tentou-se desfazer a impressão negativa associada ao Estado de Direito, apresentando-se um ângulo mais atraente para se enxergar esse conceito. Demonstrou-se que, diferentemente da imagem apresentada por alguns juristas, as normas jurídicas não são um bando de regras editadas de maneira irracional por um soberano. Ao contrário, o processo político democrático mediante o qual as leis são editadas merece respeito por simbolizar o esforço coletivo dos cidadãos em estabelecer uma estrutura comum de ação em face aos persistentes desacordos morais e políticos. A atitude de desprezo pelo texto da lei, gerada em razão do positivismo jurídico e do período ditatorial vivenciado no Brasil no século passado, já não faz mais sentido para um jurista partidário da democracia. Em uma sociedade que trata seus membros com igual respeito e consideração, a ausência de uma doutrina abrangente amplamente compartilhada exige que a reforma dos compromissos assumidos e a alteração dos rumos coletivos sejam efetuadas mediante um procedimento genuinamente democrático. O sistema jurídico apresenta-se como repositório desses compromissos políticos e sua observância é o modo encontrado para se impedir que alguém imponha de maneira unilateral sua visão de mundo.

A partir dessa conceituação elaborada por Jeremy Waldron, é possível analisar as teses associadas ao Estado de Direito a partir de uma nova perspectiva. Após uma extensa pesquisa sobre a história, a política e a teoria do Estado de Direito, Brian Z. Tamanaha (2004, p. 114126) conclui que há três temas associados à cultura desse ideal político. O primeiro diz respeito à limitação do governo pela lei como meio de restringir a tirania. Sob o enfoque waldroniano, o Estado de Direito apresenta-se não como uma mera limitação do poder dos agentes estatais, mas um ideal político que reclama a observação em razão de sua dimensão moral: o respeito às normas jurídicas é um tributo prestado ao esforço coletivo para estabelecer uma pauta comum em meio aos persistentes desacordos existentes. A limitação ao poder dos agentes estatais deve ser enxergada como uma segurança para que não haja imposição de um ponto de vista não compartilhado sobre a sociedade.

O segundo tema refere-se à ideia de legalidade formal. De acordo com Tamanaha, " $o$ Estado de Direito requer leis públicas e prospectivas, com as qualidades de generalidade, 
igualdade de aplicação e certeza. (...) A legalidade formal enfatiza uma ordem de regras estabelecida e mantida pelo governo"1. A ideia subjacente à legalidade formal é a de previsibilidade, que também ganha nova conotação a partir da ideia de dignidade da legislação. Como já visto, a moralidade intrínseca na votação majoritária exige que o texto da lei, produto de um acordo em meio ao dissenso, seja devidamente observado. Dessa forma, a previsibilidade significa que somente após a celebração desses compromissos políticos é que se torna possível a exigência de se adotar essa ou aquela postura. Isso porque a ausência de uma doutrina moral abrangente inviabiliza que se infira ex ante qual o entendimento que a maioria dos cidadãos irá adotar sobre determinado assunto. Enquanto não se edita um ato normativo explicitando qual o posicionamento assumido, a pessoa pode agir de acordo com suas convicções, sem ser incomodada juridicamente em razão de sua atitude. É disso que tratam a previsibilidade e a legalidade formal.

A terceira e última ideia associada à cultura do Estado de Direito é o estabelecimento de um governo de leis, não de homens, sumarizada por Brian Z. Tamanaha da seguinte forma:

A inspiração subjacente a essa ideia é a de que para se viver sob a regra do direito significa não se sujeitar aos imprevisíveis caprichos de outros indivíduos - sejam monarcas, juízes, agentes do governo ou colegas cidadãos. É para estar protegido contra as fraquezas humanas familiares de preconceito, erro, ignorância, avareza ou capricho. Esse sentido do Estado de Direito é baseado no medo e na desconfiança com relação aos outros. Reflete uma opção, que remonta a Aristóteles, de preferir ser governado por regras ao invés de por uma pessoa sem limites, mesmo sendo uma pessoa inteligente, em razão do medo de potenciais abusos inerentes ao poder de governar ${ }^{2}$.

Dentro da perspectiva até aqui analisada, o governo de leis conduz à necessidade do estabelecimento de normas jurídicas que indiquem a posição tomada pela coletividade para evitar que uma pessoa ou um grupo resolva o desacordo moral existente em favor de seu ponto de vista particular. Isso porque a criação e a aplicação do direito são realizações humanas, articuladas por cidadãos em seu dia a dia, de maneira que é impossível se dizer que o governo não seja de homens. No fundo, o que está em jogo é a possibilidade de que um ponto de vista minoritário seja arbitrariamente imposto por aqueles que estão investidos em cargos públicos. O que se defende na concepção de Estado de Direito aqui elaborada é que a política majoritária deve ser o meio para dirimir os desacordos existentes. Antes e depois da edição das normas jurídicas não cabe a ninguém impor o seu ponto de vista sobre os outros.

\footnotetext{
${ }^{1}$ Tradução livre de TAMANAHA, 2004, p. 119.

${ }^{2}$ Tradução livre de TAMANAHA, 2004, p. 122.
} 
Como se percebe, ao se revelar a dignidade inerente à legislação das sociedades democráticas contemporâneas, insere-se um valor moral à dimensão da adequação que impõe ao intérprete um ônus argumentativo ainda maior ao transitar para a dimensão da justificação da interpretação jurídica. Agora, passa a ser necessário demonstrar que o fundamento de sua decisão em um caso difícil é consistente com as opções realizadas pela sociedade personificada. Em meio aos persistentes desacordos, o agir em nome coletivo exige a adoção de um posicionamento que tenha sido endossado pela maioria de seus membros. Por isso a insistência de Dworkin em distinguir argumentos de princípios de argumentos de política, pois enquanto aqueles simbolizam uma ordem de valores já adotada pela comunidade em seu histórico institucional, estes representam as opções valorativas do intérprete, o que significa que sua utilização implica uma imposição indevida da de seu ponto de vista sobre a comunidade.

\section{2 - Concepções formais e substantivas de Estado de Direito}

A adoção perspectiva de Jeremy Waldron também permite compreender o que há por trás do debate travado entre os autores que defendem concepções formais e substantivas do Estado de Direito e concluir pela inadequação da captura desse conceito por uma ideologia política específica.

Atualmente há uma grande confusão acerca do significado do Estado de Direito em razão dessas apropriações indevidas por parte de concepções substantivas ${ }^{3}$. Em pesquisa recentemente realizada por Adriaan Bedner (2010), revelou-se que as diversas abordagens ao tema sugerem uma infindável lista de elementos caso todas as concepções sejam levadas em consideração. Há desde autores que se limitam a definir a legalidade formal como elemento essencial do conceito, passando por concepções mais arrojadas que associam o Estado de Direito a um governo legítimo, chegando até a definições que consideram a promoção de direitos sociais, econômicos e difusos como essenciais para a sua caracterização ${ }^{4}$.

\footnotetext{
${ }^{3}$ Para uma análise sistemática do debate acerca das concepções substantivas e formais de Estado de Direito, cf. CRAIG, 1997, p. 467-487.

${ }^{4}$ Adriaan Bedner (2010, p. 56-70) catalogou os diversos elementos presentes nas inúmeras concepções em três categorias distintas, a saber: i) elementos procedimentais, ligados ao modo de gerência da vida mediante a legalidade formal, o que traria previsibilidade, liberdade e diminuição do arbítrio; ii) elementos substantivos, concernentes a determinados valores que devem ser alcançados pelo Direito, havendo diversas abordagens que sugerem a proteção aos direitos e liberdades individuais, outras adicionando direitos sociais e econômicos e, por fim, autores que defendem a proteção de direitos coletivos e difusos sob o manto do Estado de Direito; e iii) elementos de controle, relacionados com a existência de um Judiciário independente e outras instituições, como as ONG's, encarregadas de fiscalizar se os demais elementos estão sendo observados.
} 
Dentre as concepções substantivas, talvez a de Friedrich Hayek seja a mais difundida 5 . Para o referido autor, "o Estado de Direito, obviamente, pressupõe a legalidade completa, mas isso não é o bastante: (...) ele requer que todas as leis respeitem determinados princípios" . Assim, se, por um lado, para Hayek (1978, 205-219) o Estado de Direito exige uma concepção de legalidade em que as regras devam ser gerais, abstratas, prospectivas, conhecidas, certas e aplicadas de maneira equânime, além de exigir a separação de poderes e a existência de tribunais independentes aptos a rever as decisões administrativas; por outro, apenas essas características formais não são suficientes para um regime jurídico receber a alcunha de Estado de Direito. No entender do autor, o Estado de Direito deve necessariamente assegurar a vida, a segurança e, principalmente, os direitos de propriedade dos cidadãos:

Propriedade, no amplo sentido em que é usada para incluir não apenas as coisas materiais, mas (como definiu John Locke) "a vida, a liberdade e os bens" da cada indivíduo é a única solução que o homem descobriu até agora para o problema de reconciliar a liberdade individual com a ausência de conflito. Direito, liberdade e propriedade formam uma trindade inseparável ${ }^{7}$.

Assim, para Hayek, o Estado de Direito seria uma proteção contra intervenções ilegítimas do governo na esfera patrimonial dos cidadãos ${ }^{8}$. Essa definição de Estado de Direito, vinculada a uma concepção econômico-liberal, serviu para fomentar o descrédito desse conceito, que passou a ser encarado pelos adeptos do socialismo como um instrumento a favor da manutenção do status quo, impedindo a redistribuição de renda na sociedade. Como consequência de formulações desse tipo, foram elaborados outros conceitos de Estado

\footnotetext{
${ }^{5}$ Dworkin (1985, p. 9-32), ao tratar do tema Estado de Direito, também dá a entender que adotaria uma concepção substantiva, em que a proteção de direitos morais faria parte desse conceito. Paul Craig (1997) e Brian Tamanaha (2004) concordam com essa caracterização. O tema, entretanto, não é tão óbvio como parece. Ao que tudo indica, Dworkin está fazendo uma interpretação construtiva da prática jurídica nos Estados Unidos, o que levaria a tal conclusão. David Dyzenhaus (2007, p. 80), ao analisar a concepção dworkiana, critica a vinculação da ideia de Estado de Direito a determinados ideais políticos específicos, mas entende ser possível fazer uma interpretação construtiva de uma prática jurídica qualquer, sem que haja uma vinculação $a$ priori a determinado resultado. Waldron (2004, p. 321-22), por outro lado, acredita que uma interpretação justa da obra de Dworkin aponta que sua concepção de Estado de Direito é uma concepção mais procedimental do que substantiva no sentido de permitir que as partes tenham condições de argumentar em favor de suas interpretações acerca da resposta correta para as questões jurídicas. Em resposta à Waldron, Dworkin (2004, p. 388) confirma que qualquer caracterização de sua teoria de Estado de Direito como sendo vinculada a direitos predefinidos seria uma interpretação equivocada. Em razão da complexidade do tema, parece ser preferível não classificá-lo como um exemplo inequívoco de concepção substantiva.

6 Tradução livre de HAYEK, 1978, p. 205.

7 Tradução livre de HAYEK, 1978a, p. 107.

${ }^{8}$ Oscar Vilhena Vieira (2008, p. 194) chega à mesma conclusão, afirmando que "a concepção de Estado de Direito defendida por Hayek engloba uma visão substantiva do Direito, uma noção estrita da separação de poderes e a existência de direitos liberais que protejam a esfera privada, moldada assim para servir como instrumento de proteção da propriedade privada e da economia de mercado".
} 
de Direito associados a outros ideais políticos, como é o caso do já mencionado conceito de Estado Democrático de Direito de Elías Diaz. Outra reação à ideia de que o Estado de Direito seria um conceito eminentemente liberal ocorreu em janeiro de 1959, na Conferência da Comissão Internacional de Juristas (ICJ), ocorrida em Nova Délhi. Nessa ocasião, juristas de todo o mundo firmaram a Declaração de Délhi no intuito de estabelecer um novo conceito de Estado de Direito bem mais generoso, que restou assim definido:

O Estado de Direito é um conceito dinâmico (...) que deve ser usado não apenas para salvaguardar e avançar os direitos civis e políticos dos indivíduos em uma sociedade livre, mas também para estabelecer condições sociais, econômicas, educacionais e culturais, mediante as quais as suas aspirações e dignidade podem ser realizadas ${ }^{9}$.

Como se vê, a adoção de uma concepção substantiva do Estado de Direito acaba misturando o seu conceito com outros objetivos sociais, o que gera questionamentos quanto à própria utilidade de se formular esse conceito. Em outras palavras, se o Estado de Direito se resume aos direitos que devem ser protegidos pelo ordenamento jurídico, para que necessitamos desse conceito? Nesse sentido, parecem pertinentes as observações de Robert Summers (1993, p. 135-138), para quem uma teoria formal, em virtude de seu foco concentrado nas características que compõem uma estrutura jurídica legítima, serviria melhor para avançar os valores inerentes ao Estado de Direito e a impulsionar sua institucionalização. Uma concepção formal, afirma Summers, ao estabelecer um parâmetro de legalidade, representa a melhor alternativa para diminuir a discricionariedade dos agentes públicos e evitar abusos ${ }^{10}$. Isso porque uma concepção substantiva pode dar a entender que a promoção de determinado bem justifica a violação aos princípios do Estado de Direito, o que seria um equívoco. A administração da vida por meio do Direito exige a observação de certas condições e procedimentos que, se desrespeitados, acabarão por ferir a dignidade das pessoas, ainda que os resultados alcançados sejam justos. O Estado de Direito exige que os resultados sejam atingidos por meio do Direito, obedecendo às regras do jogo, e não por qualquer outro modo.

\footnotetext{
9 Tradução livre da Declaração de Délhi, de 10 de janeiro de 1959, da International Comission of Jurists, disponível em http://www.globalwebpost.com/genocide1971/h rights/rol/10_guide.htm\#delhi. Acesso em $15 / 09 / 2012$.

${ }^{10}$ Nesse sentido, explica Summers (1993, p. 135): "But a formal theory of the rule of law affords unified focus for the foregoing institutional forms in ways that a substance theory cannot. (...) Thus, in a formal theory there is emphasis on having rules that display formal attributes to a high degree, on consistent and congruent methodology of interpretation, on reliable fact finding, on judicially detached decision free of the substance interests of litigants and of contemporary political influences, and on more consistence by the judiciary to antecedent law at point of application despite pressures for modification emergent there".
} 
Summers também salienta que uma das características mais importantes de uma teoria formal do Estado de Direito é sua compatibilidade com relação aos diversos espectros políticos $^{11}$. Em uma sociedade plural, em virtude da ausência de valores substantivos amplamente compartilhados - senão aqueles que possibilitam a participação dos cidadãos na formação do agir coletivo -, uma concepção que abrace uma ideologia específica pode, futuramente, revelar-se inapropriada e contraditória com os valores positivados nas normas legais. Como justificar a um cidadão que o Direito exige determinada conduta, mas que a legalidade (entendida de maneira substantiva) exige outra atitude? Seria não apenas contraditório, mas impreciso do ponto de vista semântico. O Estado de Direito, assim, deve enfatizar o que há de digno na administração da vida em coletividade por meio de um ordenamento jurídico, identificando os seus valores e elementos, independentemente do conteúdo das normas em determinado momento histórico.

A associação do Estado de Direito a uma concepção substantiva capitalista fomentou a ideia de que não seria possível promover transformação social por meio de normas jurídicas, o que é um equívoco. A alteração de padrões sociais através da edição de leis é o principal escopo para o estabelecimento de legislaturas ${ }^{12}$. Leis gerais e abstratas interferem na realidade social. A forma como se dá essa interferência é uma opção política. Como bem assevera Brian Tamanaha:

Apesar de ser correto que a legalidade formal pode estar em tensão com esses outros valores sociais e objetivos, é uma declaração equivocada dizer que eles são mutuamente excludentes. Uma maior distribuição igualitária pode ser atingida (embora não perfeitamente atingível) mediante regras gerais aplicadas igualmente a todos, como por exemplo, criando um limite de valores que podem ser transmitidos por meio da herança; e os recursos do governo podem ser alocados de tal maneira que ajudem a atingir uma maior igualdade através de um excelente sistema público de ensino, que poderia melhorar a mais importante desvantagem sofrida pelos pobres ${ }^{13}$.

${ }^{11}$ Cf. SUMMERS, 1993, p. 136-137 (afirmando que a neutralidade seria um dos principais atrativos para a adoção de uma teoria formal de Estado de Direito).

12 Neil MacCormick (2008, p. 12), ao relatar sua experiência como membro do Parlamento Europeu, descreve a perspectiva do Direito a partir do legislador da seguinte forma: "Não poderia haver sinal mais claro da crença das pessoas na real diferença que a mudança legislativa faz. Elas pensam que essa mudança afeta aquilo que as pessoas fazem, bem como demandas que elas podem fazer umas às outras. Elas pensam que essa mudança tem impacto real na economia e nos interesses econômicos ou de outro tipo, bem como em seu comportamento e no comportamento das empresas e governos. Elas acham que são capazes de prever os tipos de mudança que podem originar-se da mudança legislativa e é por isso que se importam com a introdução ou não de um novo dispositivo legislativo".

13 Tradução livre de TAMANAHA, 2004, p. 120. 
As políticas públicas de inclusão social do governo federal brasileiro, como o Programa Bolsa Família, são exemplos de medidas que promovem a transferência de renda para os mais necessitados através de uma legislação geral e abstrata ${ }^{14}$. É por meio da concretização dos comandos normativos que se implementa esse esquema voltado para a diminuição das desigualdades sociais.

Por essa razão, Joseph Raz (2009a, p. 224-225) afirma que a conformidade com o Estado de Direito é essencial para assegurar quaisquer que sejam os propósitos imediatos das normas jurídicas, independentemente de seu conteúdo. Partindo dessa constatação, Raz diferencia os propósitos do Direito em diretos e indiretos: o propósito direto é assegurado com a mera conformidade do Direito propriamente dito, já o indireto refere-se às consequências advindas dessa conformidade, que varia de acordo com a finalidade específica da lei. A lei que cria o Programa Bolsa Família, por exemplo, possui um propósito direto de distribuir renda para as famílias mais pobres, desde que seus dependentes frequentem o sistema público de ensino, enquanto o propósito indireto da legislação é permitir que as famílias beneficiadas consigam sair da situação de vulnerabilidade.

O princípio do Estado de Direito não tem condições de garantir a realização dos propósitos indiretos da legislação, mas é essencial para a concretização dos propósitos diretos da lei. O que se pode garantir, portanto, com relação a uma legislação específica, como a do programa Bolsa Família, é que haverá transferência de renda para as famílias mais pobres, desde que sejam cumpridos os requisitos legais. O que o Estado de Direito não pode assegurar é que as famílias contempladas sairão da condição de vulnerabilidade.

Essa distinção entre propósitos diretos e indiretos está no âmago da classificação entre concepções formais e materiais: autores que defendem um entendimento formal do Estado de Direito afirmam que a importância desse conceito é revelar os elementos e princípios que permitem que os propósitos diretos das leis sejam concretizados, enquanto os autores substancialistas advogam que o Estado de Direito deve tornar efetivo um determinado projeto subjacente às normas legais, que pode ser a diminuição das desigualdades sociais ou a proteção da propriedade privada, por exemplo.

Ao adotar uma concepção formal, Joseph Raz conclui que o Estado de Direito não se confunde com as normas jurídicas ou com os propósitos de um determinado Estado, sendo, na

\footnotetext{
${ }^{14}$ Brasil. Lei $\mathrm{n}^{\mathrm{o}}$. 10.836, de 9 de janeiro de 2004. De acordo com o sítio eletrônico referente a esse programa governamental, o Programa Bolsa Família "é um programa de transferência direta de renda que beneficia famílias em situação de pobreza e de extrema pobreza em todo o Brasil (...) e está baseado na garantia de renda, inclusão produtiva e acessa a serviços públicos. ". Disponível em http://www.mds.gov.br/bolsafamilia. Acesso em 16/09/2012.
} 
verdade, uma virtude associada à capacidade das normas jurídicas de guiarem as condutas dos indivíduos. Ou seja, para o referido autor, o Estado de Direito seria uma característica presente em alguns ordenamentos jurídicos que impedem o uso arbitrário do Direito por parte dos agentes públicos ${ }^{15}$. Ordenamentos virtuosos possuem normas prospectivas, gerais, claras, públicas e relativamente estáveis, além de colocarem à disposição dos cidadãos tribunais imparciais e acessíveis no afã de supervisionar a observância das normas jurídicas e sancionar eventuais desvios ${ }^{16}$.

Raz então explica que o Estado de Direito é uma virtude desejável por i) minimizar os perigos de os agentes públicos agirem arbitrariamente, ii) estabilizar as relações sociais e iii) possibilitar que os cidadãos estabeleçam planos em longo prazo (autodeterminação). Contudo, por ser apenas uma virtude negativa - que evita que arbitrariedades sejam perpetradas - a legalidade pode eventualmente entrar em choque com outros valores substantivos ${ }^{17}$. Às vezes, a propriedade privada, por exemplo, pode ser afetada em razão da observância de uma lei que disponha sobre confisco. Para Raz, o Estado de Direito, por ser um conceito essencialmente formal, mostra-se indiferente com relação aos valores adotados pela legislação, referindo-se apenas à forma como o Direito torna-se efetivo em uma sociedade.

De maneira semelhante, Lon Fuller (1969) elaborou uma das mais influentes concepções formais de Estado de Direito, afirmando que as normas de um ordenamento considerado jurídico deveriam ser necessariamente gerais, claras, públicas, estáveis, prospectivas, sem contradições, além de demandar conformidade com relação ao que dispõem as regras e não exigir que se faça o impossível ${ }^{18}$. Essas características comporiam a moralidade intrínseca do Direito. A adoção dessas características formais imediatamente impediria a prática de atos arbitrários, possibilitando que os cidadãos gerenciem suas próprias vidas de maneira autônoma ${ }^{19}$. Na visão de Fuller, portanto, a observância desses princípios

\footnotetext{
${ }^{15}$ Nesse sentido Raz (2009a, p. 214) afirma: "This is the basic intuition from which the doctrine of the rule of law derives: the law must be capable of guiding the behavior of its subjects".

${ }^{16}$ Cf. RAZ, 2009a, p. 214-221.

17 Joseph Raz (2009a, p. 228) assevera sobre esse ponto que: "Since the rule of law is just one of the virtues the law should possess, it is to be expected that it possess no more than prima facie force. It has always to be balanced against competing claims of other values".

18 Raz afirma que sua concepção não é semelhante à de Lon Fuller, pois não crê que o Estado de Direito seja essencialmente bom. O Estado de Direito seria, na verdade, um instrumento que, assim como uma faca, poderia ser utilizado para finalidades boas e ruins. Além disso, Raz afirma que o Estado de Direito é apenas um ideal a ser atingido e que, na prática, vários de seus princípios são violados, sem que isso deixe de caracterizar um ordenamento como jurídico. Assim, se para Fuller uma violação radical com o Estado de Direito significaria um rompimento com a legalidade, Raz entende que sempre se trata de uma questão de gradação. Cf. RAZ, 2009a, 223-225.

19 David Dyzenhaus (2007, p. 72) resume o argumento de Fuller assim: "A system that fails completely to meet one principle, or fails substantialy to meet several, would not, in Fuller's view, be a legal system. It would not qualify as government under law - as government subject to the rule of law. Further, a tyrant who wanted to
} 
impede que o Estado manipule a conduta das pessoas, reconhecendo-as como sujeitos capazes e autônomos ${ }^{20}$.

É essa qualidade formal associada ao trato das relações humanas através do Direito reconhecida como valor moral por Fuller ou como virtude por Raz - que faz com que o Estado de Direito seja reconhecido como algo desejável. Trata-se de um sentimento expresso em várias situações do dia a dia. Quando um órgão da imprensa afirma que "os operadores do Direito precisam refletir (...) até que ponto o julgamento do mensalão está sendo pautado por circunstâncias alheias aos sagrados princípios do Direito ${ }^{21 ",}$, subentende-se que, caso a decisão não esteja se baseando estritamente nas normas jurídicas, haverá a perda de algo de valioso para a sociedade. Do mesmo modo ocorre quando o Justice Paul Stevens, da Suprema Corte norte-americana, afirma, em seu voto em Bush v. Gore, precedente no qual se definiu o resultado das eleições presidenciais de 2000, que “ainda que nunca saibamos com certeza a identidade do vencedor das eleições presidenciais, a identidade do perdedor é bastante clara: a confiança da nação nos juízes como guardiões imparciais do Estado de Direito ${ }^{22 \%}$. Infere-se daí que Paul Stevens critica a atitude de juízes de lidar de maneira política com questões jurídicas, dando a entender que há algo de especial no modo de resolver os conflitos por meio do Direito, que se diferencia da política ordinária.

Quando se fala em violação ao Estado de Direito, as críticas não se endereçam apenas ao Poder Judiciário. Quando Alexandre Aguiar (2009, p. 1) afirma que os atos secretos do Senado Federal que beneficiavam parlamentares "é uma afronta ao Estado de Direito", o que ele quer dizer é que a concessão de benefícios estatais, para ser legítima, deve se dar por meio de normas jurídicas que cumpram os requisitos do Estado de Direito. De maneira semelhante, quando, no fim do ano de 2011, a Associação dos Juízes Federais (AJUFE) publicou uma nota pública considerando o ato da Presidente Dilma Rousseff de não encaminhar a proposta orçamentária elaborada pelo Presidente do Supremo Tribunal Federal ao Congresso Nacional "um atentado ao Estado de Direito" ${ }^{23}$, criticava-se o fato de alguém, em razão de seu cargo,

\footnotetext{
govern thorough the medium of law would have to comply with the eight principles, and this would preclude rule by arbitrary decree and secret terror, which, Fuller said, is the must effective medium for tyranny".

${ }^{20}$ Fuller (1969, p. 162) explica: "To embark on the enterprise of subjecting human conduct to rules involves of necessity a commitment to the view that man is, or can become, a responsible agent, capable of understanding and following rules, and answerable for his defaults. Every departure from the principles of law's inner morality is an affront to man's dignity as a responsible agent".

${ }^{21}$ Informativo eletrônico Migalhas, $\mathrm{n}^{\circ}$. 2.961, de 18 de setembro de 2012.

${ }^{22}$ Tradução livre de Bush v. Gore, 531 U.S. 98, p. 128-129.

${ }^{23}$ Nota Pública de 16/12/2011 do Presidente da Associação dos Juízes Federais (AJUFE). Disponível em: http://www.ajufe.org.br/portal/index.php?option=com_content\&view=article\&id=4286..$\quad$ Acesso em 20/09/2012.
} 
entender-se imune à necessidade de obedecer às determinações legais e agir conforme seus caprichos.

Em todos esses casos, o que se está afirmando é que um ato estatal, independentemente de seu conteúdo, para não ser arbitrário, deve se submeter ao regime legal estabelecido. Os magistrados, assim como os demais agentes públicos, subordinam-se ao Direito. Em última análise, nas democracias contemporâneas, o único modo de se exercitar legitimamente o poder estatal é pela observância de normas jurídicas. Qualquer outro meio de governança, seja através de decretos, manipulação ou coerção, qualifica o Estado como autoritário.

O Estado de Direito, portanto, refere-se a um modo especial de gerência dos atos estatais, independentemente de seu conteúdo. Não por outro motivo o historiador britânico marxista Edward Thompson (1987, p. 357) afirmou que o Estado de Direito é "um bem humano incondicional", contrariando o pensamento intelectual de esquerda de sua época que visualizava nesse ideal político um instituto capitalista. Se a reflexão de Thompson é verdadeira - como parece ser -, o vínculo entre o conceito de Estado de Direito e a dignidade humana é algo que precisa ser elucidado. O que torna a submissão da vida em coletividade um ordenamento normativo algo moralmente atraente? Como a intermediação das relações intersubjetivas por meio do Direito respeita a dignidade dos membros de uma dada sociedade? Esse é o tema dos próximos tópicos.

\section{3 - Estado de Direito e dignidade humana}

No capítulo anterior, demonstrou-se que a produção legislativa por um parlamento numeroso que busque representar os diversos pontos de vista da sociedade e que decida as questões a partir do voto da maioria é um procedimento digno, por simbolizar o esforço coletivo para se estabelecer democraticamente um projeto comum em face aos desacordos morais e políticos persistentes, sem impor unilateralmente uma posição. O reconhecimento de que todos merecem igual consideração e respeito na tomada de posição em nome da sociedade confere legitimidade à legislação. A dignidade da utilização dessas normas jurídicas no trato das relações humanas, entretanto, é uma questão distinta que também merece ser elucidada conceitualmente. Para facilitar a compreensão das interfaces entre dignidade humana e a legalidade, torna-se importante distinguir, desde já, dois aspectos do fenômeno jurídico que são relevantes para o conceito de Estado de Direito. 
O estabelecimento de um governo de normas, não de pessoas, tem como escopo impedir que haja manipulação de condutas por parte dos governantes. Em uma sociedade decente, os cidadãos são tratados como sujeitos autônomos, capazes de refletir moralmente sobre as suas opções de vida, sendo a edição de normas jurídicas prévias um tributo a essa capacidade humana de autodeterminação. O Estado de Direito permite que os cidadãos façam escolhas, planejem o seu agir, independentemente da intermediação de qualquer agente estatal. A capacidade de autoaplicação das normas jurídicas pelos cidadãos, que as utilizam como guias de conduta, é essencial para a compreensão do Estado de Direito, mas não resume toda a história.

Por mais que as pessoas aceitem e compreendam o conteúdo das leis, a transposição das razões gerais das normas jurídicas para uma situação concreta por vezes se mostrará problemática. Nessas situações, será necessário o estabelecimento de procedimentos imparciais que permitam aos interessados produzirem provas e exporem seus argumentos com relação à incidência, ou não, dos dispositivos legais ao seu caso. A questão jurídica deve, então, ser resolvida de maneira imparcial, mantendo hígidos os compromissos institucionais assumidos, pois se fosse possível manipular o conteúdo das normas no momento da aplicação, não haveria sentido em utilizá-las como guias de conduta. Essa faceta judicial da prática jurídica também é importante para a compreensão do Estado de Direito.

A partir da identificação desses dois momentos distintos em que as normas jurídicas são utilizadas pode-se afirmar, na linha de Neil MacCormick (2008, p. 19-23), que a legalidade possui dois aspectos distintos, muitas vezes contraditórios, que merecem ser igualmente levados em consideração: a) o aspecto estático, em que o foco do Estado de Direito volta-se para os valores da previsibilidade e da certeza necessários para que as normas sirvam de guias de condutas; b) o aspecto procedimental, que insiste no caráter argumentativo da prática jurídica na resolução de conflitos interpretativos. Qualquer concepção jurídica que ignore qualquer um desses dois aspectos se mostrará inadequada. Essas duas dimensões do fenômeno jurídico são levadas em consideração por Jeremy Waldron em sua definição de Estado de Direito:

A ideia de Estado de Direito é que o direito deve estar acima de todas as pessoas e órgãos da nação. A autoridade estatal deve ser exercida dentro de uma moldura restringida por normas públicas. O poder político deve ser controlado pelo direito - como bem colocado por Albert Venn Dicey - em contraste "com um sistema de governo baseado no exercício de pessoas com poderes amplos arbitrários e discricionários". Além disso, o Estado de Direito requer que os cidadãos tenham acesso ao direito em dois 
sentidos. O primeiro requer que o direito seja acessível, o que significa que seja promulgado de maneira prospectiva como um conhecimento público de maneira que as pessoas podem previamente consultá-lo e calcular os impactos de suas ações e transações. A segunda parte do requisito de acesso ao Estado de Direito é que haja procedimentos legais disponíveis para que as pessoas se protejam contra abusos de poder de agentes públicos e privados. Tudo isso requer a independência do Judiciário, a prestação de contas dos funcionários públicos, a transparência dos negócios públicos e a integridade dos procedimentos judiciais ${ }^{24}$.

Waldron (2011, p. 6-14) afirma que todos os elementos mencionados em sua formulação remetem-se à ideia de dignidade humana, compreendida como o reconhecimento da capacidade do sujeito de controlar e regular as suas ações de acordo com as normas e razões disponíveis ${ }^{25}$. Dignidade humana, portanto, para Waldron, significa ter autodeterminação, não estando sujeito à dominação e/ou à manipulação de outras pessoas. Toda a ideia de garantir direitos fundamentais envolve o reconhecimento da capacidade moral dessa pessoa de discernir por si o que é correto e incorreto, justo e injusto. Somente os que possuem essa capacidade merecem ser considerados autônomos e, portanto, ter direitos que garantam essa autonomia.

A partir da identificação dos aspectos estático e procedimental do Estado de Direito, pode-se dizer que esse ideal político respeita e leva em consideração a dignidade das pessoas em três níveis distintos: ao oferecer normas jurídicas como guias de conduta, ao disponibilizar procedimentos judiciais para dirimir as dúvidas quanto à aplicação das normas e ao possibilitar que o indivíduo formule argumentos jurídicos que apresentem a sua versão dos fatos e das normas.

Na primeira hipótese, a dignidade relaciona-se à capacidade dos indivíduos de levarem as normas jurídicas em consideração na definição de seu agir. Como bem adverte Manoel Gonçalves Ferreira Filho (2009, p, 180), “o princípio da legalidade é, por um lado - o primeiro a enunciar a liberdade, ainda que pela negativa -, o princípio geral da liberdade. $O$ homem é livre para fazer tudo exceto o que a lei proíbe". A ideia principal inserida nessa faceta do Estado de Direito é a possibilidade de autoaplicação das normas pelos sujeitos que, a partir da compreensão do conteúdo das leis, pode modular sua conduta de acordo com o

\footnotetext{
${ }^{24}$ Tradução livre do WALDRON, 2012, p. 6-7.

${ }^{25} \mathrm{O}$ conceito de dignidade é assim elaborado por Waldron $(2011$, p. 2-3): "Dignity is the status of a person predicted on the fact that she is recognized as having the ability to control and regulate her actions in accordance with her own apprehension of norms and reasons that apply to her; it assumes she is capable of giving and entitled to give an account of herself (and of the way in which she is regulating her actions and organizing her life), an account that others are to pay demand that her agency and her presence among us as human being be taken seriously and accommodated in the lives of others, in others' attitudes and actions towards her, and in social life generally"
} 
Direito. A ênfase nessa possibilidade de autoaplicação voluntária pelos cidadãos é o que para Waldron (2011, p.8) distingue de maneira definitiva um sistema jurídico de outro que funciona primariamente por meio de trapaças e manipulação.

O segundo modo pelo qual o Estado de Direito respeita a dignidade humana é criando procedimentos decisórios que levem os argumentos dos cidadãos a sério. Assim, caso a autoaplicação das normas não se mostre possível ou haja uma disputa sobre a correta aplicação das normas, o Estado deve disponibilizar uma via oficial para dirimir os conflitos interpretativos que trate os indivíduos com dignidade. Não se trata de produzir qualquer decisão, mas estruturar procedimento em que as partes tenham condições materiais de participar da construção da decisão. Na resolução dos conflitos, deve-se oportunizar aos interessados a chance de apresentar argumentos e contra-argumentos, produzir provas, recorrer a instâncias superiores, etc. Waldron insiste no ponto de que as características procedimentais da via judicial é que possuem dimensão moral. Trata-se daquilo que Manoel Gonçalves Ferreira Filho (2009, p. 23-242) denomina princípio da justicialidade e seus corolários do acesso à justiça, do devido processo legal e da ampla defesa e do contraditório. Jeremy Waldron esclarece esse ponto:

Essas são características abstratas [dos sistemas judiciários]. Mas elas não são abstrações arbitrárias. Elas capturam um sentido profundo e importante associado fundamentalmente com a ideia de um sistema jurídico, que o direito é um modo de governar pessoas que reconhece que possuem uma perspectiva própria para apresentar no momento da aplicação da norma à sua conduta ou situação. Aplicar uma norma a um indivíduo humano não é a mesma coisa que decidir o que fazer com um coelho ou com uma casa dilapidada. Envolve prestar atenção a um ponto de vista e respeitar a personalidade do indivíduo com quem se está lidando. Sendo assim, essa atitude encarna uma ideia crucialmente dignitária - respeitar a dignidade daqueles a quem a norma será aplicada como capazes de explicarem a sua situação ${ }^{26}$.

A terceira forma pela qual o Estado de Direito presta tributo à dignidade humana diz respeito à argumentação jurídica propriamente dita. Com efeito, a prática jurídica não se resume a ouvir a versão das partes. Exige-se a apresentação de argumentos por parte dos envolvidos. O ordenamento jurídico apresenta-se como algo complexo que pode ser compreendido pelos cidadãos. Normalmente, não há apenas uma norma aplicável de maneira mecânica a uma situação da vida, mas um emaranhado de regras, princípios e precedentes.

\footnotetext{
${ }^{26}$ Tradução livre de WALDRON, 2011, p. 12.
} 
Não obstante, o Direito aspira ser algo coerente e sistemático, o que exige que essas informações sejam articuladas de maneira racional e persuasiva.

O Estado de Direito, ao demandar que os cidadãos formulem proposições jurídicas complexas a seu favor, trata-os como agentes capazes de relacionar as normas com os fatos e situações da vida. Os argumentos jurídicos são então apresentados na linguagem de obrigações jurídicas, requerendo algo que lhe é devido, e não como meros pedidos de favores aos magistrados. Essa confiança na capacidade dos cidadãos articularem seus interesses por meio de argumentos jurídicos, transformando suas reivindicações em demandas que são levadas a sério pelos tribunais, também representa um tributo à dignidade humana para Waldron (2011, p. 12-14).

\section{4 - Elementos do Estado de Direito}

Argumentou-se, ao longo deste capítulo, que o Estado de Direito é uma virtude inerente à utilização de normas jurídicas na intermediação das relações intersubjetivas por respeitar a dignidade dos membros da sociedade que são considerados sujeitos racionais, e não meros objetos a serviço dos detentores do poder. O Estado de Direito, portanto, é uma forma de tratamento que possui um valor moral intrínseco, não se confundindo com os méritos das normas jurídicas em si. O propósito do presente tópico é analisar os elementos específicos que precisam ser observados para dar concretude a esse ideal político.

Seguindo a linha de raciocínio desenvolvida até aqui, Jeremy Waldron adota uma concepção formal de Estado de Direito, afirmando que o modo de administração da vida em coletividade por meio do Direito já possui um significado moral intrínseco. Para o autor, o cidadão, ao ser submetido a um ordenamento que possa ser considerado jurídico, é respeitado como agente moral, autônomo e capaz, ou seja, é tratado com dignidade, independentemente dos valores substantivos efetivamente protegidos pelo sistema ${ }^{27}$. Waldron sustenta, então, que o conceito de Estado de Direito deve ser entendido separadamente de outros conceitos políticos existentes em nossa tradição constitucional, como os direitos humanos, a democracia e a separação de poderes. Não obstante haver várias conexões e tensões entre os referidos

\footnotetext{
${ }^{27}$ Waldron (2008, p. 41) explica: "The features that I have suggested are definitive of law are formal, structural, institutional, and procedural in character. They are not substantive features, though they are not without moral significance. I think they define something worth treasuring as well as something worth studying. We have noted various ways in which these characteristics define a mode of governance that takes people seriously as dignified and active presences in the world-persons with lives of their own to lead, with points of view about how their lives relate to the interests of others, and with reason and intelligence to exercise in grasping their society's system of order".
} 
ideais que precisam ser investigadas, uma compreensão independente da legalidade facilita a identificação de atos e correntes filosóficas tendentes a enfraquecê-lo ou a debilitá-1o ${ }^{28}$.

Nesse sentido, Waldron adota posição semelhante à de John Finnis, que define Estado de Direito como a "qualificação dada a um ordenamento jurídico que se encontra funcionando de maneira saudável" ${ }^{29}$. Tal atitude implica a identificação de uma posição focal $^{30}$ do conceito de Estado de Direito, na qual são especificadas as características constitutivas de um ordenamento jurídico em perfeito funcionamento. Essa atitude permite avaliar as estruturas jurídicas existentes, medindo em graus os distanciamentos do caso central. Isto significa que a concepção waldroniana de Estado de Direito possibilita a aferição de quanto uma comunidade respeita o referido ideal político, sem que se tenha que afirmar que um mero desvio do caso central constitua um rompimento total com a legalidade ${ }^{31}$.

Assim como o conceito de democracia, a qualificação de um regime como de Estado de Direito relaciona-se mais com o modo de tratamento dos cidadãos do que com o preenchimento de requisitos específicos. Alguns exemplos são didáticos a esse respeito. A pluralidade de partidos políticos é desejável e talvez faça parte de um conceito ideal de democracia, mas a sua ausência - como ocorre claramente nos Estados Unidos, em que somente dois disputam de fato as eleições - não significa um rompimento com o regime democrático nesse país. Noutro giro, a mera existência de eleições regulares e sufrágio universal, conquanto sejam requisitos essenciais, não são suficientes para qualificar um país sem oposição política e alternância de poder como democrático.

Com relação ao Estado de Direito, a abordagem é semelhante. O importante para definir o respeito à legalidade relaciona-se ao tratamento dos cidadãos como sujeitos capazes de utilizar as normas como guias de conduta. $\mathrm{O}$ fato de haver leis positivadas não garante a denominação de um regime de dominação como Estado de Direito. Há uma carga normativa no uso desse conceito político que não pode ser ignorada. Caso os tribunais não oportunizem defesa aos interessados e julguem sistematicamente aplicando normas de maneira retroativa,

${ }^{28}$ Cf. WALDRON, 2007, p. 97-99.

29 Tradução livre de FINNIS, 1980, p. 270.

30 A ideia de uma posição focal foi elaborada primeiramente por Aristóteles, para designar o caso central da análise de um determinado objeto. John Finnis (1980, p. 8-16) utiliza-se deste artifício para elaborar sua concepção de Direito, defendendo que a teoria do direito deve focar seu estudo no ponto de vista que melhor justifique o fenômeno jurídico, e não a partir da perspectiva de quem queira burlar as normas.

31 Waldron (2008, p. 44) explica esse ponto da seguinte forma: "Much like the criteria I used for specifying what we mean by law, the requirements associated with the Rule of Law are all matters of degree. They are all matters of degree because first, a system of governance may satisfy the Rule of Law in some areas of governance and not others; second, the Rule of Law comprises multiple demands, some of which may be satisfied while others are not; and third a particular norm or directive may be more or less clear, more or less stable, more or less well-publicized, and enforced through more or less scrupulous procedures". 
não há que se falar em legalidade. O Estado de Direito, nesse sentido, é o modo de tratamento ideal que exige um constante monitoramento e aprimoramento das instituições públicas para que não haja manipulação das condutas $^{32}$. Os desvios devem ser criticados e as práticas aperfeiçoadas. Sempre é possível se aproximar um pouco mais da posição focal.

Partindo do diagnóstico do tópico anterior sobre os modos pelos quais o Estado de Direito interage com a dignidade humana, Waldron enumera 5 (cinco) características dos ordenamentos jurídicos que preservam e amplificam essas conexões. Cortes, normas públicas e gerais, positividade, orientação para o bem comum e sistematicidade são os elementos que Waldron considera relevantes para a compreensão do Estado de Direito ${ }^{33}$.

\subsection{1-Cortes}

O primeiro requisito do Estado de Direito refere-se à existência de instituições oficiais criadas para aplicar as normas fixadas em nome da sociedade aos casos individuais. Essas instituições devem funcionar mediante um procedimento estruturado para decidir de maneira imparcial sobre os direitos e responsabilidades dos indivíduos, oportunizando às partes produzirem provas e aduzirem seus argumentos, que deverão ser levados a sério pelos encarregados de solucionar a disputa judicial. O importante para Waldron é o modus operandi dessas instituições, que deve respeitar a dignidade dos indivíduos envolvidos no litígio:

O mais importante é que se trata de algo procedimental: a operação de uma corte envolve um modo de proceder que oferece àqueles que são imediatamente interessados a oportunidade de peticionar e produzir provas, sendo a produção dessas provas realizada em estrita observância às normas de regência e orientada para as normas acerca das quais há questionamentos sobre a sua aplicação ${ }^{34}$.

Para Waldron (2008, p. 21-24), audiências de instrução, procedimentos imparciais e todas as garantias associadas à ideia de devido processo legal processual são características

\footnotetext{
${ }^{32}$ Nesse sentido, Waldron (2008, p. 45): "The fact that we work with a roughly defined threshold for a system of governance to count as law does not mean that we rest satisfied with these minimum credible achievements. There is always room for improvement, and there is also danger of deterioration. The criteria that I have outlined make themselves available as sources of continuing normative pressure to reach higher up scale and to resist the downward pressure that other exigencies of polity inevitably generate".

${ }^{33}$ As descrições dos elementos que serão trabalhadas nos próximos itens foram basicamente retiradas do texto The Concept and the Rule of Law, de Jeremy Waldron (2008).

34 Tradução livre de WALDRON, 2008, p. 23.
} 
essenciais, ao invés de contingenciais, de ordenamentos jurídicos saudáveis ${ }^{35}$. Os procedimentos judiciais capturam uma dimensão fundamental associada à ideia de tratamento respeitoso dos indivíduos: reconhece-se que os litigantes possuem algo a dizer sobre os fatos e as normas que serão aplicadas à sua conduta.

Julgamentos por comissões militares, sem direito à defesa, com provas obtidas mediante tortura, como os que ocorrem em Guantánamo, não preenchem os requisitos do Estado de Direito, por mais que os agentes denominem a instituição como um tribunal ${ }^{36}$. Quanto menos participativos e mais impositivos forem os métodos de resolução de conflitos, mais distante se estará do ideal de Estado de Direito.

\subsection{2 - Normas gerais e públicas}

Esse elemento do Estado de Direito requer que as normas sejam gerais, públicas, prospectivas e identificáveis, servindo efetivamente como guias de conduta para os cidadãos. A mera existência de comandos normativos não significa que os cidadãos consigam utilizá-las em suas práticas cotidianas. Em regimes em que as normas são secretas ou que se aplicam aos casos ocorridos no passado, os indivíduos são, na verdade, objetos de manipulação dos agentes estatais.

A generalidade é a característica que possibilita que as normas jurídicas sejam a base para a edição de todos os atos jurídicos particulares, incluindo as decisões judiciais. A partir da norma abstrata é que são construídos os juízos individuais e concretos. Segundo Waldron (2008, p. 24-28), a ideia de generalidade é parte integrante da nossa compreensão sobre o Estado de Direito. Dizer que uma norma tem aplicação geral significa que ela será aplicada de acordo com os princípios da impessoalidade e da igualdade. Não por outro motivo fala-se em "leis da física" ou "lei moral de Kant", identificando a palavra lei com a noção de generalidade.

Já a publicidade diz respeito à necessidade de dar conhecimento das normas jurídicas àqueles cujas condutas serão avaliadas de acordo com os seus padrões. Somente com

\footnotetext{
${ }^{35}$ Em sentido semelhante, Gilmar Mendes (2007, p. 478) afirma que "a boa aplicação das garantias [constitucionais do processo] configura elemento essencial de realização do princípio da dignidade humana na ordem jurídica. Como amplamente reconhecido, o princípio da dignidade na ordem jurídica. Como amplamente reconhecido, o princípio da dignidade da pessoa humana impede que o homem seja convertido em objeto dos processos estatais".

${ }^{36}$ Cf., nesse sentido, o editorial do The New York Times de 11/10/2008, afirmando que o Estado de Direito está sendo restaurado na administração Bush depois de um juiz federal ordenar a imediata soltura de 17 prisioneiros de guerra custodiados em Guantánamo. Disponível em: http://www.nytimes.com/2008/10/12/opinion/12sun2.html? r=0. Acesso em 20/09/2012.
} 
conhecimento ex ante do contéudo das normas é que os cidadãos podem criar expectativas e organizar suas vidas. Também é inerente à noção de publicidade que as normas devam ser relativamente estáveis, pois os cidadãos necessitam ter o mínimo de conhecimento sobre quais são as condutas vedadas e permitidas pelo ordenamento, o que é impossível quando os parâmetros legais são modificados com frequência. Assim, ainda que a criação e a modificação das normas sejam frutos da vontade humana (requisito positividade que será analisado a seguir), a regulação da vida em sociedade por meio do Direito também é uma escolha dos cidadãos.

Essas duas características têm como escopo permitir que os cidadãos consigam utilizar as normas jurídicas como guias de conduta. Em outras palavras, a publicidade e a generalidade das normas são características essenciais para que os indivíduos, considerados como autônomos e responsáveis, possam utilizar os comandos jurídicos independentemente da intermediação de qualquer agente público. A principal ideia associada ao caráter público e geral das normas é a possibilidade de sua autoaplicação por parte dos indivíduos sujeitos a um ordenamento jurídico $^{37}$, tema já abordado no tópico anterior. Ao permitir que os indivíduos organizem suas vidas de acordo com as normas postas, o Direito os trata como sujeitos capazes de realizar ações voluntárias e de autocontrole racional. Nesse contexto, quanto maior for a aptidão de um ordenamento jurídico de propiciar guias seguros de conduta, mais próximo se estará da concretização do Estado de Direito.

\subsection{3 - Positividade}

O terceiro elemento da concepção de Waldron (2008, 28-31), a positividade, diz respeito à consciência dos membros da comunidade de que o Direito é uma construção humana que pode ser modificada e ajustada como eles bem entenderem. O elemento da positividade refere-se ao reconhecimento de que o Direito não é algo misterioso que deva ser manuseado apenas por técnicos com capacidades sobre-humanas para revelar o seu conteúdo, mas consubstancia-se no resultado de acordos políticos celebrados mediante um processo democrático em que os cidadãos participaram, ainda que indiretamente, de sua elaboração.

Aqui há uma ligação explícita no pensamento de Waldron entre o Estado de Direito e a dignidade da legislação. Em uma sociedade democrática, a necessidade de se estabelecer um

\footnotetext{
${ }^{37}$ Waldron (2008, p. 27) enfatiza: "I believe this pervasive emphasis on self-application is definitive of law and that law is therefore sharply distinct from a system of rule that works primarily by manipulating, terrorizing, or galvanizing behavior".
} 
projeto coletivo em meio à realidade divida e plural exige a organização de processos políticos decisórios em que a posição prevalecente emerge por meio de uma votação majoritária após a confrontação pública dos diversos pontos de vista sobre o tema. A necessidade de tratar todos com igual respeito e consideração exige que nenhuma decisão seja tomada unilateralmente, mas politicamente construída pelos membros da sociedade, sem desrespeitar a opinião de ninguém. Nesse contexto, o Direito é aquilo que a sociedade, após deliberar por meio de seus órgãos representativos decidiu que deveria ser, e não algo divino ou que deva ser encontrado no subconsciente coletivo. Essa origem democrática é essencial para a concepção de Estado de Direito de Waldron.

O princípio da positividade, portanto, explica a essência daquilo que chamamos de Direito: é algo humano, contingente e produto de processos históricos. Aqueles submetidos a um Estado de Direito sabem que estão subordinados a uma ordem normativa que, caso se mostre inconveniente ou inadequada, é suscetível de ser modificada. Os próprios cidadãos compreendem (ou deveriam compreender) as razões pelas quais determinados bens foram protegidos. Os membros da sociedade é que decidem em última análise o que é o Direito. A ideia subjacente ao princípio da positividade é o da liberdade: as pessoas são livres para organizarem o ordenamento jurídico da maneira que desejarem, sem qualquer limitação externa $^{38}$. Quanto maior essa consciência de autodeterminação dos cidadãos em uma dada sociedade, mais próximo se estará do ideal de Estado de Direito.

\subsection{4 - Orientação para o bem comum}

A orientação para o bem comum, penúltimo elemento da concepção waldroniana, visa a qualificar os regimes jurídicos a partir do propósito dos membros encarregados de administrar a criação e a aplicação das normas jurídicas. Como já se viu, o ideal do Estado de Direito tem como escopo evitar que em uma sociedade democrática as condutas dos cidadãos sejam manipuladas pelos detentores do poder. Não por outro motivo fala-se em estabelecer um governo de leis, não de homens. A legalidade visa a despersonificar o ordenamento jurídico, que passa a ser compreendido como o resultado do esforço coletivo para estabelecer uma estrutura comum que possibilite a cooperação dos indivíduos. É da essência do Estado do Direito a promoção do interesse público em contraposição ao interesse meramente privado.

\footnotetext{
${ }^{38}$ Waldron (2008, p. 29-31): "The norms by which they are ruled could be otherwise. It is only our decision to have them and keep them as a basis of governance that explains why these norms are law and not some others. (Once again, the idea of legislation conveys this most explicitly.) The idea of law, therefore, conveys an elementary sense of freedom, a sense that we are free to have whatever laws we like".
} 
O princípio da orientação para o bem público, assim, refere-se ao funcionamento das instituições públicas, que por suposição devem ser voltadas para a realização do interesse coletivo. Ou seja, subentende-se que em um Estado de Direito os agentes públicos orientamse por um senso de correção que transcende os interesses e as preferências dos detentores do poder. Seria no mínimo contraditório imaginar que as instituições que representam a comunidade preocupam-se apenas com o benefício dos poucos que estão no comando desses órgãos. Em suma, no Estado de Direito, o sistema legal está a serviço da comunidade, e não do interesse de uma classe ou grupo ${ }^{39}$. Qualquer manifestação oficial que nitidamente contrarie essa orientação está em confronto com esse ideal político.

\subsection{5 - Sistematicidade}

A sistematicidade, último elemento citado por Waldron (2008, p. 32-36), refere-se aos argumentos jurídicos propriamente ditos elaborados como justificativas das decisões judiciais. Como já referido no tópico anterior, o Estado de Direito reconhece os cidadãos como sujeitos capazes de articular proposições jurídicas a seu favor, o que exige que a forma como o ordenamento jurídico é utilizado pelos agentes públicos para a resolução dos casos judiciais seja compreendido pelos participantes da prática jurídica. Como nem sempre há uma regra que se aplique de maneira automática ao caso em exame, mas uma infinidade de normas, doutrinas e precedentes que de certa forma tangem o tema, torna-se necessário o esclarecimento das convenções interpretativas utilizadas pelos magistrados para que os cidadãos possam efetivamente construir argumentos que influenciem a decisão final.

É por meio da ideia de sistematicidade que Waldron procura dar conta desse caráter acumulativo do Direito, sugerindo que, na medida em que o ordenamento vai se tornando cada vez mais complexo - com a edição de novos diplomas e o avanço da jurisprudência deve ser mantida a coerência de todo o empreendimento por meio de interpretações construtivas por parte dos membros que justifiquem o emaranhado de normas como um projeto único e global.

\footnotetext{
${ }^{39}$ Confira, nesse sentido, a explicação de Waldron (2008, p. 32): "That law presents itself in a certain way - as standing in the name of the public and as oriented to the public good - seems to me to be one of its defining characteristics. I do not mean that nothing counts as law unless it actually promotes the public good. (..)This is an aspirational or orientational idea, not a substantive one. But it is nevertheless very significant”.
} 
Nesse sentido, a sistematicidade assemelha-se à noção de integridade ${ }^{40}$ elaborada por Dworkin $^{41}$. Para Waldron, um argumento jurídico consistente baseia-se na projeção da lógica e dos valores subjacentes às normas jurídicas nas áreas de incerteza e controvérsia, usando mecanismos como analogia e referência aos princípios implícitos como parâmetros para suprir as lacunas do ordenamento. Assim, ainda que as decisões sejam inteiramente novas, as conclusões dos tribunais devem ser apresentadas como produtos da aplicação do Direito existente, e não como a criação de um Direito novo. A sistematicidade, portanto, confere legitimidade a decisões judiciais ao exigir que o intérprete se esforce em demonstrar que suas conclusões são as que melhor refletem os compromissos políticos institucionalmente assumidos pela sociedade, e não uma mera opinião pessoal sobre o assunto.

Nesse aspecto, Waldron mira criticar os autores adeptos do pragmatismo jurídico, como Richard Posner, para quem os juízes devem decidir com vistas a produzir o melhor resultado para a sociedade, independentemente do material jurídico existente. Waldron afirma que o pragmatismo debilita o Estado de Direito, já que desconsidera a necessidade de os argumentos jurídicos serem avaliados a partir de um parâmetro racional que seja acessível aos jurisdicionados, impossibilitando-os de elaborar uma proposição jurídica a seu favor que produza impacto na decisão judicial. Em outras palavras, para a concepção waldroniana, caso as normas jurídicas não consigam inibir o raciocínio do intérprete, iguala-se a argumentação jurídica à argumentação puramente política, o que faz com que o Estado de Direito não tenha qualquer serventia.

O elemento da sistematicidade, portanto, informa que as decisões judiciais devem levar em consideração as normas jurídicas de tal maneira que os cidadãos compreendam a estrutura de um argumento jurídico válido e consigam formular proposições jurídicas em seu benefício. Isso requer que os agentes públicos sintam-se constrangidos pelas normas jurídicas ao tomarem suas decisões.

Conclui-se este capítulo com a compreensão de que o Estado de Direito, na concepção de Jeremy Waldron, é um conceito político moralmente atraente por respeitar a dignidade

\footnotetext{
${ }^{40}$ Waldron (2004, p. 36) clarifica que: "With systematicity, there are arguments for codification and for the promotion of a greater element of what Ronald Dworkin has called 'integrity' in both legislation and common law".

${ }^{41}$ Confira também: "That's what it means to treat like cases alike. (Citizens) can reasonably expect each judge to make the best effort he can to resolve their case on the basis of coherent principles that also make sense of the way other cases have been resolved un the community they belong to. Dworkin argues that the importance of this aspiration - an aspiration to coherence, to integrity in legal reasoning - is undiminished by the certainty that different judges will approach this exercise with different values and come up with different conclusions. I am convinced that Justice in Robes does more to open up new options in our thinking about the Rule of Law than a whole library full of book by opinionated pragmatists”. In: WALDRON, 2006, p. 10.
} 
humana tanto no aspecto estático quanto no procedimental da experiência jurídica, o que se dá por meio da observância dos cinco elementos que amplificam as interfaces entre legalidade e dignidade, a saber: cortes, normas públicas e gerais, positividade, orientação para o bem comum e sistematicidade. No próximo capítulo serão explanadas as formas pelas quais o Neoconstitucionalismo, como concepção jurídica, debilita essa ideia de Estado de Direito, apontando os elementos da definição waldroniana que são fragilizados pelas teses defendidas pelos autores ditos neoconstitucionais. 


\section{Capítulo 7 - Estado de Direito e Neoconstitucionalismo: tensões e contradições}

\section{1 - Diagnosticando as contradições}

Repassados os elementos que compõem a concepção de Estado de Direito para Jeremy Waldron, surgem algumas constatações relevantes. Em primeiro lugar, é possível notar que a noção de Estado de Direito está intimamente ligada à concepção de Direito adotada pelo intérprete. A depender da ênfase dada a cada um dos aspectos chega-se a resultados distintos que limitam a compreensão do jurista. Um positivista, por exemplo, fixa-se basicamente no estudo do uso das normas jurídicas como guias de conduta, destacando os elementos da positividade e do caráter público e geral dos comandos jurídicos, relegando toda a parte procedimental do Estado de Direito a segundo plano. Já as teorias que focam na argumentação para a compreensão do Direito, como o pragmatismo jurídico e o Neoconstitucionalismo, visualizam a criação do Direito pelos tribunais como caso central da teoria jurídica e menosprezam a necessidade da autoaplicação das normas jurídicas pelos cidadãos em seu dia a dia.

Uma concepção abrangente do Estado de Direito deve levar em consideração todas as perspectivas nas quais a dignidade humana é respeitada na utilização do Direito como medium no trato das relações intersubjetivas, o que conduz à segunda constatação. Há, atualmente, forte tendência - muito clara no Neoconstitucionalismo - de focar-se no conteúdo das decisões judiciais como principal meio de proteção dos direitos fundamentais. Parte-se do pressuposto de que nada mais há a ser valorado além da própria substância da decisão judicial. Atitudes mais formais e menos criativas têm sido consideradas interpretações jurídicas empobrecidas. O que se tentou demonstrar nos dois últimos capítulos é que a relação entre a dignidade humana e o ordenamento jurídico não é tão simples como esses autores fazem supor. Há uma moralidade intrínseca na forma como as leis são editadas, na utilização das normas jurídicas como guias de conduta, nos procedimentos judiciários e na construção dos argumentos jurídicos consistentes que não pode ser simplesmente descartada.

No momento da interpretação judicial, todos esses fatores devem ser levados em consideração. Não por outro motivo, Dworkin (2006, p. 171) conclui que o respeito pelos compromissos políticos adotados pela sociedade personificada - consubstanciado no que o autor denominou dimensão da adequação - será maior na medida em que o intérprete 
considerar mais legítimos os procedimentos que levaram ao seu estabelecimento. O ideal do Estado de Direito apresenta-se como a necessidade de respeito pelos compromissos institucionais assumidos pela sociedade, representando a própria dimensão da adequação da interpretação jurídica.

Haverá casos, entretanto, em que as razões substantivas serão tão estridentes que a desobediência às razões legais se mostrará justificável. Dworkin (2006, p. 206) cita como exemplo o ato do Presidente Abraham Lincoln de suspender o habeas corpus durante a Guerra Civil norte-americana, mesmo havendo a disposição constitucional que somente autoriza que tal medida seja adotada pelo Congresso, como o ato que possibilitou acabar com a escravidão nos Estados Unidos. Nesse caso, os fins justificaram os meios (ilegais). Tais casos, em que as razões de justiça substantiva superam a moralidade intrínseca ao Estado de Direito, devem ser absolutamente excepcionais. A legitimidade de sua adoção então deve ser aferível prima facie, o que não é algo simples nas sociedades contemporâneas plurais.

Em uma democracia saudável, em razão da persistência dos desacordos morais e políticos, a legislação merece o respeito por parte dos magistrados, que devem ser muito cautelosos ao declarar a inconstitucionalidade de um ato, pois se estará confrontando, de um lado, a dignidade do conteúdo da decisão e, do outro, a dignidade do ato legislativo e das pessoas que o utilizaram como um compromisso válido na condução de suas vidas, confiando na sua execução por parte do Estado. Em suma, o Estado de Direito, entendido como o respeito aos compromissos institucionais estabelecidos, também é uma questão de dignidade que não pode ser olvidada.

O Neoconstitucionalismo, com seu foco na transformação da sociedade por meio da interpretação constitucional, enfraquece o ideal do Estado de Direito elaborado por Waldron em vários aspectos. A ênfase no controle de constitucionalidade das leis, por exemplo, enfraquece os elementos da positividade e da orientação ao bem comum ao desconfiar da política ordinária como instrumento apropriado para o estabelecimento dos compromissos em nome da sociedade ${ }^{1}$. O Neoconstitucionalismo parece partir do pressuposto de que os parlamentares agem imbuídos apenas de interesses privados e de que há uma moralidade externa à política que pode ser consultada pelos juízes. Tais premissas contrariam a ideia de que as normas jurídicas são editadas por procedimentos democráticos criados com o fito de coordenar as condutas em meio à pluralidade de perspectivas.

\footnotetext{
${ }^{1}$ Uma demonstração dessa desconfiança pode ser extraída da passagem em que Luís Roberto Barroso (2009, p. 324-325) afirma que uma das crenças inerentes ao constitucionalismo contemporâneo é a "de que uma corte de justiça progressista pode promover a revolução humanista que o processo político majoritário não é capaz de fazer".
} 
De modo semelhante, os procedimentos judiciais festejados por Waldron nas Cortes relacionados à participação dos interessados na construção das decisões judiciais individuais, seja na produção de provas ou no oferecimento de argumentos jurídicos - ficam comprometidos a partir do momento em que o Poder Judiciário passa a decidir regularmente questões de ampla repercussão, modificando estruturalmente os compromissos sociais. Isso porque poucos têm acesso e condições de efetivamente influir nesses julgamentos ${ }^{2}$. É importante realçar, também, que os procedimentos judiciários criam incentivos para que os casos individuais sejam decididos de maneira desinteressada quanto aos resultados. No momento em que questões que interessam a toda a população são decididas pelas Cortes, a imparcialidade dos magistrados, que também são interessados, fica comprometida. Isso se torna mais problemático quando se autoriza a utilização de argumentos de política nessas decisões.

É com relação aos elementos da publicidade/generalidade das normas e da sistematicidade, entretanto, que o Neoconstitucionalismo parece estar mais em tensão com os ideais do Estado de Direito. Ao questionar insistentemente a constitucionalidade das normas jurídicas e ao defender uma intepretação constitucional totalizante e transformadora, essa corrente doutrinária acaba minando alguns dos modos pelos quais a legalidade respeita e amplifica a dignidade humana. Em razão de sua relevância, esses tópicos serão abordados separadamente.

\section{2 - O Neoconstitucionalismo e a função das normas jurídicas}

Como já visto, uma forma mediante a qual a dignidade é respeitada em um Estado de Direito parte da edição de normas jurídicas claras, públicas, prospectivas e gerais basicamente os requisitos enumerados por Fuller e Raz - para que sirvam como guias de conduta, o que é assimilado por Waldron no segundo elemento de sua concepção. Pessoas capazes de refletir moralmente possuem condições de conduzir suas vidas de forma autônoma, utilizando as diretrizes normativas como razões a serem ponderadas em seu agir

\footnotetext{
${ }^{2}$ A doutrina constitucional brasileira tem lidado com esse déficit democrático do controle de constitucionalidade a partir da ideia de uma "sociedade aberta de intérpretes da Constituição", elaborada inicialmente pelo autor alemão Peter Häberle, que impõe a abertura do processo constitucional às partes interessadas por meio da figura do amicus curiae e das audiências públicas. Ocorre, entretanto, que não há, até o momento, nenhum estudo empírico específico sobre o impacto das audiências públicas nas decisões dos ministros do Supremo Tribunal Federal. Além disso, ainda que essas intervenções sejam possíveis, poucos têm condições de patrocinar a defesa de seus interesses em causas perante o mais alto tribunal do país, o que diferencia esses procedimentos dos judiciais ordinários, nos quais as partes devem participar, sob pena de ferimento do contraditório e ampla defesa. Sobre a doutrina de Peter Häberle e sua recepção no Brasil, cf. COELHO, 1998.
} 
prático. Quando as leis são incompreensíveis, secretas e/ou retroativas, o agente é sempre surpreendido com a sua aplicação, o que não se coaduna com o ideal de Estado de Direito. O respeito à dignidade humana demanda que as normas sejam antecipadamente conhecidas e que prescrevam condutas exequíveis com a finalidade de permitir que as pessoas programem suas vidas sem caírem em ciladas. Previsibilidade e certeza jurídica, nesse sentido, são predicados do respeito à autonomia dos sujeitos.

Quando há intensos questionamentos sobre quais normas devem ser obedecidas - algo que o Neoconstitucionalismo incita a todo instante - há uma inevitável perda de confiança na aptidão do Direito de orientar condutas, o que fere o Estado de Direito. Para se compreender melhor esse ponto, é oportuno um aprofundamento sobre o modo pelo qual as pessoas utilizam as normas em seu dia a dia, o que se torna possível a partir da análise conceitual da ideia de autoridade elaborada por Joseph Raz, talvez um dos filósofos que melhor compreenderam essa função de guia das normas jurídicas.

De acordo com Raz (2009, p. 183-189), todos os seres humanos considerados pessoas racionais estão sujeitos à moral. Em outras palavras, todos os que possuem capacidade de refletir sobre o certo e o errado, o justo e o injusto, são considerados pessoas dignas de respeito (portadores de direitos, portanto) que conseguem raciocinar moralmente. Em suas vidas cotidianas, esses sujeitos possuem diversas razões para agir em regime de concorrência: razões morais, razões meramente de interesse pessoais, razões religiosas, razões baseadas em superstições etc. Todas essas razões são razões de primeira ordem $^{3}$. Ao agir, a pessoa pondera as diversas razões de primeira ordem existentes e adota uma delas que servirá de motivação de seu ato. Ou seja, a justificativa de um ato será sempre a razão que o agente entendeu ser a mais adequada naquele momento.

Como visto no capítulo anterior, nas sociedades contemporâneas, mesmo nas questões de princípios, há desacordos infindáveis entre os membros da sociedade sobre quais direitos temos, sobre qual a atitude mais justa a ser tomada em determinada circunstância etc. Ainda que todos agissem de boa-fé, ou seja, de acordo com o que entendem ser o mais correto para a sociedade como um todo (agir moral), ainda assim não haveria uma unidade de entendimento. Os desacordos morais que temos são profundos e duradouros. As razões de primeira ordem, portanto, mostram-se insuficientes para promover a coordenação de condutas entre os indivíduos, pois não conduzem ao consenso, mas ao conflito. O Direito surge como o mecanismo que possibilita o estabelecimento de uma estrutura social comum voltada para a

\footnotetext{
${ }^{3}$ A linguagem de razões de primeira e segunda ordem é utilizada por Raz em seu livro Pratical Reasons and Norms (1999, p. 39-45).
} 
realização de atividades em conjunto. Como decorrência lógica da existência desses desacordos, as normas jurídicas, ao endossar uma razão de agir não acatada unanimemente por todos, são sempre de certa forma autoritárias. Não por outro motivo, Raz afirma que a ideia de autoridade é chave para se compreender o fenômeno jurídico.

A concepção de autoridade de $\operatorname{Raz}$ (1985, p. 299) funda-se em três teses básicas: i) tese da subordinação: toda diretiva autoritária deve basear-se em razões que se aplicam aos sujeitos dessas diretivas; ii) tese da preferência: o fato de uma autoridade requerer a realização de uma ação é uma razão para sua execução, que não pode ser ponderada junto com as demais razões de primeira ordem, mas substituí-las; e iii) tese da justificativa normal: alguém possui autoridade sobre a outra caso demonstre ao subordinado que ele estará em melhor condição do que se seguisse suas próprias razões.

Assim, uma diretiva de um médico a um atleta para que repouse durante alguns dias com a finalidade de curar uma lesão muscular, por exemplo, possui autoridade, subordinando seu paciente que adotará essa razão de agir, pois o médico, em função de seu conhecimento técnico, deixará o paciente em condições melhores do que se ele voltasse imediatamente a praticar exercícios, conforme mandam suas próprias razões. Da mesma forma, um pai terá autoridade para substituir as razões de uma criança que somente gostaria de comer chocolate em suas refeições por estar em melhores condições para tomar essa decisão pelo filho em razão de sua experiência.

As diretivas de uma autoridade consubstanciam-se em razões de segunda ordem, que excluem ou possuem preferência com relação às razões de primeira ordem. Por mais que o atleta e a criança estejam convictos sobre qual medida tomar - retomar os exercícios e alimentar-se com chocolates, respectivamente - prevalecem, ao final, as razões formuladas pela autoridade, que excluirão/substituirão as razões pessoais dos agentes subordinados. A autoridade jurídica funciona de maneira semelhante: as normas jurídicas - sejam regras, precedentes ou princípios - são razões de segunda ordem que excluem as razões pessoais dos indivíduos em seu agir. Ainda que alguém entenda que seria melhor dirigir pela via da contramão para chegar mais rapidamente ao seu destino, o motorista subordina-se às razões estatuídas no código de trânsito, que, por possuir autoridade, bloqueia suas razões pessoais (razões de primeira ordem).

Como visto acima, para se exercer autoridade sobre alguém, Raz afirma ser necessário comprovar que no final das contas o subordinado estará em melhor situação se seguir as diretivas autoritárias do que se utilizar suas próprias razões. Com relação ao Direito, há três motivações básicas que conduzem à conclusão de que a obediência às normas jurídicas 
produz um saldo final favorável ao indivíduo. As duas primeiras dizem respeito aos valores da autonomia e da cooperação já tratados. A terceira refere-se à ideia de eficiência: a partir do momento em que uma matéria é regulamentada pelo Direito, define-se como as várias razões incidentes sobre determinada questão devem ser equalizadas, o que desincumbe o sujeito do ônus de refletir sobre o assunto no momento em que a situação prevista na norma ocorra no mundo dos fatos. Voltando ao exemplo do trânsito: caso não houvesse uma norma fixando qual via deve ser utilizada, os motoristas sempre teriam que ponderar as razões favoráveis e contrárias referentes à adoção das diversas alternativas. Como o Direito já predefiniu o resultado dessa ponderação, evita-se que os cidadãos tenham que novamente resolvê-la. Do mesmo modo, a existência de regras eleitorais evita que a cada eleição se discuta uma série de questões políticas complicadas como o período de mandato, o dia da votação, se haverá segundo turno, se a votação será majoritária ou representativa etc.

Raz (2009, p. 188) conclui que a adoção de um ordenamento jurídico é em si uma opção moral da sociedade que, a partir de então, modifica a relação dos seus membros com a moral de três diferentes maneiras. Em primeiro lugar, retira-se dos indivíduos o direito de decidir em várias circunstâncias qual seria a conduta mais correta a ser adotada, excluindo essas razões morais da formação do juízo. Uma norma jurídica que obrigue os médicos a fornecerem indiscriminadamente todos os dados requisitados pelos pacientes, e.g., retira desses profissionais a liberdade de deliberar, de acordo com a sua ética, sobre quais informações seriam adequadas de transmitir em determinadas circunstâncias. Em segundo lugar, ao positivar certas considerações morais por meio de normas jurídicas públicas, possibilita-se avaliar de maneira uniforme a conduta de seus membros, tornando mais justo o tratamento estatal diferenciado entre os que obedecem e os que não obedecem à lei. Por fim e em terceiro lugar, o Direito torna mais fácil a concretização de objetivos morais desejáveis a partir da coordenação das condutas dos vários agentes. Nesse sentido, Raz conclui de maneira positiva que:

[As instituições jurídicas] tornaram possível a civilização urbana que conhecemos nos últimos um ou dois séculos - grande número de pessoas vivendo com relativa animosidade lado a lado, apreciando as liberdades e as ricas amenidades cívicas em conjunto e ao mesmo tempo em separado, cada um por si, uma civilização urbana do tipo que o mundo não havia conhecido antes e que provavelmente ainda será apreciada por muito tempo.

Ocorre que as normas jurídicas somente podem ser consideradas autoritárias caso sejam utilizadas como razões de segunda ordem e efetivamente excluam as razões de primeira 
ordem na formação do agir individual, o que ocorre se duas condições lógicas forem observadas. Primeiro, as razões autoritárias devem ser aceitas independentemente de seu conteúdo, pois caso se exigisse a concordância das pessoas com os méritos das diretrizes, as normas jurídicas não teriam força excludente. Segundo, os comandos normativos devem ser conhecidos e compreendidos pelos subordinados, caso contrário eles continuarão a utilizar as razões de primeira ordem ${ }^{4}$.

O Neoconstitucionalismo, entretanto, contribui para a não realização dessas duas condições. Em um primeiro plano, essa corrente doutrinária, ao questionar insistentemente a validade das normas, faz com que elas percam a capacidade de orientar os agentes. $\mathrm{O}$ raciocínio neoconstitucional é: a Constituição de 1988 estatui primordialmente uma gama de princípios que se espalham por todo o ordenamento jurídico, tornando toda a aplicação jurídica em uma questão constitucional. Seguindo o modelo Brown, esses princípios são considerados valores abstratos - e não compromissos político-constitucionais específicos - o que significa que o seu conteúdo é sempre indeterminado, devendo ser procedida uma ponderação entre as diversas razões envolvidas para se definir qual a norma concreta aplicável ao caso. Isso faz com que sempre seja possível transformar os compromissos institucionais assumidos por outros que o intérprete entenda mais adequados. Ao visualizar o Direito como instrumento de mudança social, o Neoconstitucionalismo inverte a presunção de constitucionalidade das normas, que passam a ter sua constitucionalidade dependente de um projeto emancipatório. Mesmo nas relações particulares, a Constituição pode operar efeitos e alterar o conteúdo das avenças. Todo esse quadro faz com que seja impossível o conhecimento de antemão das diretrizes autoritárias que devem ser observadas, o que impede a autoaplicação das normas jurídicas pelos cidadãos.

Em segundo plano, o que se percebe é que todas as teses do Neoconstitucionalismo buscam permitir que as razões de primeira ordem possam ser novamente rediscutidas no momento da aplicação da norma. A constitucionalização do direito festejada pelos autores neoconstitucionalistas leva inexoravelmente a um juízo de ponderação em que argumentos de princípio e de política são balanceados, o que significa dizer que a norma jurídica não tem o condão de excluir qualquer razão de primeira ordem. Dito de outra forma, a identificação das normas jurídicas válidas depende da ponderação de inúmeras considerações por parte do

\footnotetext{
${ }^{4}$ Essas duas condições são assim apresentadas por Raz (1985, p. 303): “The two features are as follows. First, a directive can be authoritatively binding only if it is, or is at least presented as, someone's view of how its subjects ought to behave. Second, it must be possible to identify the directive as being issued by the alleged authority without relying on reasons or considerations on which the directives purports to adjudicate".
} 
intérprete, que são exatamente as mesmas considerações que o Direito deveria de antemão avaliar e substituir por aquela endossada pela norma.

Isso significa dizer que o Direito, ao não conseguir excluir as razões de primeira ordem do destinatário da norma, perde totalmente sua função de intermediação, tornando-se sem autoridade e, consequentemente, sem utilidade. Perde-se, com isso, em coordenação, autonomia e eficácia, abrindo uma brecha para que os agentes públicos manipulem as condutas dos cidadãos. Não obstante essas conclusões mostrarem-se óbvias, aparentemente não foram internalizadas pelos neoconstitucionalistas brasileiros analisados ${ }^{5}$. Eduardo Ribeiro Moreira, por exemplo, dá a entender que seria possível a coordenação das condutas dos cidadãos a partir do simples compartilhamento dos valores constitucionais:

A sociedade aberta, que interpreta o texto constitucional, após adquirir uma consciência constitucional, é a primeira a cumprir a Constituição. A efetividade constitucional, então, aparece em tempos de uso regular das normas constitucionais. $\mathrm{O}$ intérprete, na fase de aplicação do direito constitucional, só se manifesta quando provocado - como representante das partes ou no exercício da jurisdição constitucional - e isso só ocorre quando houver conflito - seja ele concreto ou abstrato. Quando a Constituição é eficaz, aplicada naturalmente, são difusos os seus intérpretes. Deve-se realçar a execução voluntária do direito, sem interferência estatal, pois a aplicação do direito é a medida oficial, quando encontrada na fase judicial, mas longe de ser a única ${ }^{6}$.

$\mathrm{O}$ autor parece sugerir que, a partir do momento em que os valores constitucionais passam a ter efetividade, inicia-se um ciclo virtuoso em que os cidadãos passam a aplicá-los voluntariamente, guiando suas condutas de acordo com os requisitos substantivos de moralidade. Tal argumento é ao mesmo tempo ingênuo e simplista. É ingênuo porque acredita que até o desenvolvimento do Neoconstitucionalismo as pessoas não teriam utilizado diretamente a moralidade para intermediar as relações intersubjetivas por desconhecerem essa possibilidade. Como se viu, as normas jurídicas servem exatamente para padronizar as condutas a fim de tornar possível a realização de objetivos sociais desejáveis em uma sociedade marcada pelo dissenso, o que dificilmente ocorreria caso cada um agisse conforme suas próprias razões.

\footnotetext{
${ }^{5}$ Apesar de Daniel Sarmento (2007 e 2009) se mostrar preocupado com o "oba-oba" e a "carnavalização" constitucional, o autor não consegue conceitualizar essa sensação de perda na invocação excessiva de princípios por parte dos intérpretes. O diagnóstico não veio com a cura, que é uma teorização acerca da ideia de legalidade e de Estado de Direito que identifique os valores inerentes a esse conceito que devem ser preservados.

${ }^{6}$ MOREIRA, 2008, p. 90-91.
} 
Ademais, o argumento é simplista ao desconsiderar que, ainda que as pessoas se guiassem apenas por razões morais (e não por interesses pessoais ou religiosos), mesmo assim haveria entre si desacordos morais irreconciliáveis. Ao defender o Neoconstitucionalismo como uma fórmula mágica que permite a convivência civilizada dos cidadãos por intermédio de valores morais, o autor parece desconsiderar a realidade extremamente dividida de nossa sociedade. Eduardo Ribeiro Moreira parece não compreender a essência do Direito, que é exatamente coordenar de modo digno as condutas entre indivíduos que discordam profundamente sobre quais razões de primeira ordem são relevantes para solucionar os complexos problemas que se apresentam no dia a dia.

Ao fim, o Neoconstitucionalismo faz com que as normas jurídicas percam a sua capacidade de excluir as razões do intérprete, que pode rediscutir o seu mérito sempre que for aplicá-las. O caráter totalizante do Neoconstitucionalismo (oriundo da ideia de constitucionalismo dirigente) e seu foco na transformação da sociedade incitam que se questione constantemente a constitucionalidade das leis, que, por isso, estão em constante revisão. Como consequência, os cidadãos quedam-se desorientados, o que infringe a dignidade da pessoa submetida a um ordenamento jurídico ${ }^{7}$.

\section{3 - Neoconstitucionalismo e interpretação constitucional}

A segunda contradição latente entre Neoconstitucionalismo e Estado de Direito diz respeito ao aspecto procedimental do fenômeno jurídico. O elemento da sistematicidade, mencionado por Waldron, aduz que os juízes devem decidir os casos com base em argumentos que possam ser racionalmente compreendidos pelos participantes da prática jurídica, com vistas a possibilitar a formulação de alegações em seu favor. Em um Estado de Direito, todos os agentes públicos ou privados estão submetidos à lei e à Constituição, o que significa dizer que o material legal deve de alguma forma limitar a atuação dos agentes públicos, notadamente dos magistrados. Se fosse permitido aos juízes decidirem unicamente de acordo com suas convicções morais, não haveria sentido em estruturar um complexo ordenamento jurídico.

No caso da interpretação constitucional, a questão de como manter a fidelidade ao material jurídico existente torna-se ainda mais problemática em razão das inúmeras cláusulas

\footnotetext{
${ }^{7}$ Raz (2009, p. 350-351) destaca, nesse sentido, que "the uncertainty affects people's ability to function. It is made worse if it generates a fear of continuous change, leading to a sense of dislocation and loss of orientation".
} 
constitucionais abertas, que muitas vezes mostram-se conflitantes. Essa complexidade normativa, contudo, não pode levar à conclusão de ser impossível identificar as respostas jurídicas corretas em um Estado de Direito. O princípio da sistematicidade impõe que haja critérios racionais que tornem possível diferenciar e avaliar a interpretação jurídica em contraste com a argumentação meramente política. Como encaixar a ideia de mudança constitucional por meio da interpretação judicial em uma concepção jurídica tida como legítima sob o ponto de vista do Estado de Direito? Como se torna possível dar uma guinada jurisprudencial sem configurar um rompimento com os compromissos institucionais assumidos pela sociedade personificada?

As complicações inerentes a este tema não têm passado despercebidas pelos autores trabalhados. Como salientado nos capítulos 3 e 4, Dworkin destrincha a interpretação jurídica em duas dimensões distintas e complementares: a dimensão da adequação e a dimensão da justificação. Enquanto a primeira impõe a manutenção dos compromissos institucionais assumidos, a segunda exerce força para que esses compromissos sejam modificados para melhor se adequarem aos requisitos substanciais de justiça. Ao longo desta Tese, demonstrouse que a dimensão da adequação possui uma moralidade implícita, que é a moralidade do próprio Estado de Direito. Assim, quando o intérprete se vir perante uma questão em que há bons argumentos para a adoção de um novo entendimento jurídico, terá de avaliar se os valores promovidos pela decisão superam as violações à dignidade humana que serão perpetradas com o abandono dos compromissos antigos. Trata-se, portanto, sempre de uma decisão eminentemente moral. Não só o mérito da decisão em si deve ser levado em consideração, mas uma série de outros valores que serão violados caso seja efetuada uma mudança jurisprudencial. Há sempre duas forças morais em atuação: de um lado requer-se conformidade; do outro, reforma.

O tema também foi tratado por Raz (2009, p. 350-370). Segundo o autor, uma Constituição possui autoridade não em razão da figura de seus fundadores, mas por servir à necessidade social de estabilidade das práticas governamentais ao longo de várias gerações. A estabilidade, portanto, é um valor inerente ao constitucionalismo ${ }^{8}$. Para que não seja

\footnotetext{
${ }^{8}$ Raz (2009, p. 351) define assim as razões inerentes à estabilidade: "These are some of the many, mostly familiar reasons for preferring stability to instability. They do not amount to a rejection of change, but they create reason to prefer continuity to change, unless there are good reasons for the change. They add to main and powerful conservative argument: While it is possible to predict the direct consequences of small changes in legal and social practices, changes that take place within existing frameworks and do not upset them, it is impossible to predict the effect of radical, large-scale changes. They are liable to affect the legal and social framework, which constitutes the background conditions that make predictions of social events possible. Hence, while radical reform may be inspired by cogent reasons to bring about different social conditions, there is no adequate advance reason to believe that it will bring about the hoped-for consequences. In itself
} 
necessário um novo texto constitucional a cada mudança de configuração social, há também a necessidade de ajustamento dessa prática social por meio de mudanças que não impliquem ruptura completa com o paradigma. Por mais que haja boas razões para os juízes manterem a prática da forma como se encontra, de vez em quando também há bons motivos para que eles alterem o significado da Constituição a fim de adequá-la às necessidades emergentes. Essa possibilidade de alteração é o que torna a interpretação constitucional ferramenta jurídica importante:

Porque a interpretação é tão central para o direito constitucional? A resposta, como sempre ocorre quando há uma razão para se utilizar a interpretação, liga-se a uma combinação das razões para respeitar a Constituição como ela existe e razões para deixar em aberto a possibilidade de utilizá-la caso seja necessário uma reforma, um ajuste ou um desenvolvimento com vistas a remover as deficiências que sempre há ou deficiências que emergem quando o governo ou a sociedade que é governada se modifica ao longo do tempo'.

Raz (2009, p. 354-360) argumenta que adotar uma interpretação conservadora (backward-looking) ou inovadora (forward-looking) é uma questão moral que deve decidida pelos juízes. Nesse balanço, vários elementos devem ser considerados, dentre eles os referentes aos arranjos institucionais. Logo, se a legislação deve ser o método de intermediação por excelência para modificação e adequação do ordenamento jurídico, a interpretação constitucional inovadora às vezes se justifica como instrumento para romper com a atuação de grupos de interesses que impedem as mudanças necessárias. Do mesmo modo, quanto mais legítima for considerada uma prática constitucional, menores serão os incentivos para a adoção de uma interpretação inovadora; ao passo que quanto mais intensos forem os defeitos do arranjo institucional, maior a pressão para uma atuação judicial reformista. $\mathrm{O}$ processo de emenda constitucional também deve ser considerado: quanto mais fácil for a alteração da Constituição, menos razões morais haverá para reformas via Poder Judiciário.

Vale ressaltar que para Raz a prática constitucional não se refere apenas ao texto constitucional, mas aos entendimentos compartilhados sobre o significado dos compromissos institucionais firmados, de maneira que as normas, os princípios e os precedentes têm aptidão

this is no argument against radical reform and change. It does not show that radical change is likely to be for the worse. But it does undercut many reasons that people often advocate in pressing for radical change. Taken together with the advantages of stability, it adds to a certain conservative attitude sometimes expressed by saying that in relatively stable and decent societies there is a presumption in favour of continuity against which all proposals for change should be judged".

${ }^{9}$ Tradução livre de RAZ, 2009, p. 353. 
semelhante de servir como razões de segunda ordem. Uma interpretação é inovadora quando rearticula esse entendimento fixando novas posturas a serem observados pelos cidadãos em seu agir prático. Joseph Raz (2009, p. 367-370) conclui que a manutenção da prática constitucional na forma como se encontra sempre possui várias virtudes, mas que o formalismo não impede a adoção de interpretações inovadoras. Ou seja, ainda que haja uma alternativa conservadora disponível, pode ser desejável uma atitude reformista que dê uma melhor formatação à prática jurídica em face das mudanças sociais, políticas ou econômicas. O autor então reconhece que mesmo quando não há indeterminação jurídica sobre um tema, é sempre possível se adotar uma interpretação inovadora que modifique o estado das coisas. A conveniência de se fazer isso ou não é uma questão moral.

Assim, percebe-se que o exercício jurisdicional de declarar inconstitucionais leis ou práticas governamentais, por representar uma mudança ou revisão do material jurídico existente, consubstancia-se em uma questão moral. Qual argumento moral justifica a adoção de uma interpretação inovadora é assunto para ser tratado por uma teoria constitucional que distinga os argumentos justificados dos ilegítimos. De fato, segundo David Richards, as tarefas de uma teoria constitucional são, simultaneamente, de elucidar o estado atual da prática constitucional e de indicar o modo como ela deve desenvolver-se:

As tarefas de uma teoria constitucional parecem ser, como também normalmente é o caso da teoria jurídica, tanto explicativa quanto normativa, preocupada tanto com a compreensão quanto com recomendações de mudança. As tarefas são, no mínimo: primeiro, dar explicações para as formas históricas da doutrina constitucional; segundo, articular um ponto de vista normativo crítico que permita avaliar as formas constitucionais históricas e contemporâneas; e terceiro, dar uma justificativa tanto para a estabilidade quanto para a modificação no direito constitucional ${ }^{10}$.

Conforme visto no capítulo 1 , a justificativa que anima a prática do controle de constitucionalidade na atualidade - e em certa medida o próprio constitucionalismo - é a ideia de proteção de direitos fundamentais contra os eventuais abusos por parte do poder político ${ }^{11}$. A dignidade humana é o conceito-chave para a compreensão da atual prática constitucional e a diretriz que justifica o desenvolvimento e as mudanças no direito constitucional. O Estado de Direito, como visto, enquadra-se na perspectiva do constitucionalismo em razão do modo

\footnotetext{
10 Tradução livre de RICHARDS, 1979, p. 296.

${ }^{11}$ Essa ideia é sintetizada por Manoel Gonçalves Ferreira Filho (2009, p. 3) da seguinte forma: " $[O$ constitucionalismo moderno] é o movimento jurídico-político desenvolvido a partir do último quartel do século XVIII, que reclama não só a adoção em todos os Estados do orbe de Constituições escritas, documentais, mas que elas tenham como conotação o desiderato de impedir o arbitrio”.
} 
digno como os cidadãos submetidos são tratados. Assim, a reforma do material jurídico por meio da interpretação constitucional somente se mostrará viável quando ficar demonstrado que a aplicação de determinada norma jurídica implicará em intolerável violação à autonomia dos cidadãos. O modo de diagnosticar essa agressão necessita ser mais bem elucidado para fins do elemento da sistematicidade, embora sejam necessárias duas considerações preliminares.

Em primeiro lugar, revela-se relevante a advertência de Jeffrey Goldsworthy (2003) no sentido de que não se deve superestimar a ideia de transformação por meio de uma interpretação constitucional inovadora, seja porque raramente ocorrem mudanças paradigmáticas em razão de decisões judiciais ou porque essa perspectiva não descreve com fidelidade o trabalho interpretativo dos juízes. De acordo com o autor, os advogados dificilmente utilizam a linguagem de mudança em suas alegações, sendo também muito improvável que um magistrado aja conscientemente com a intenção de alterar os compromissos democraticamente assumidos. Nessa perspectiva, qualquer caracterização da prática jurídica como algo focado primariamente com a transformação social apresenta uma compreensão inadequada do sentido dessa prática.

Goldsworthy (2003, p. 177-178) aponta então quatro situações ordinárias em que o conteúdo da Constituição é ajustado por meio da interpretação constitucional, sem que isso signifique uma genuína atitude inovadora: i) correção de erro judicial anteriormente cometido, acarretando uma mudança jurisprudencial com vistas a restaurar o verdadeiro sentido constitucional; ii) densificação normativa das cláusulas constitucionais vagas por parte das Cortes; iii) adequação do sentido de cláusulas constitucionais em razão da mudança das circunstâncias políticas, sociais ou econômicas da sociedade, o que é mais justificável com relação à interpretação de textos antigos, como a Constituição norte-americana; e iv) interpretações que, apesar de se afastarem do texto literal da cláusula, buscam ser fiéis ao propósito original da norma. $\mathrm{O}$ autor defende que nesses casos, apesar de haver uma mudança na prática constitucional, os juízes procuram apenas interpretar algo já existente com vistas a sua manutenção, ao invés de bradar que estão realizando uma transformação radical da sociedade.

A intensidade das modificações introduzidas nessas hipóteses pode ser mais profunda do que Goldsworthy sugere. O importante nessa abordagem é a percepção de que, mesmo quando os atores jurídicos promovem alterações no Direito, normalmente não o fazem de maneira deliberada por se sentirem constrangidos pelos requisitos do Estado de Direito. Como pontuado no capítulo 3, toda interpretação construtiva de uma prática social deve explicar os 
elementos da prática na forma como ela existe, e não inventar uma prática nova. Ao reputar como caso central da prática jurídica uma função que os juízes normalmente não desempenham, o Neoconstitucionalismo se afasta realidade fática, o que faz com que sua teoria seja menos factível.

Em segundo lugar, vale relembrar as lições de Waldron (1999 e 2003), que afirma que nas sociedades democráticas contemporâneas há desacordos morais profundos sobre os contornos dos direitos fundamentais, mesmo entre pessoas que acreditam em direitos. Esse argumento, junto com a constatação de que do ponto de vista normativo não há nada que conduza a conclusão de que a argumentação levada a cabo no Judiciário conduz a melhores decisões morais do que se realizada no Legislativo faz com que o autor neozelandês advogue pela extinção do controle jurisdicional de constitucionalidade por se revelar um artifício antidemocrático. Não obstante a jurisdição constitucional ser uma prática constitucionalmente estabelecida no Brasil, as observações de Waldron não podem ser simplesmente ignoradas por juristas que cultuam os valores da democracia.

No caso brasileiro, em que há menção expressa aos poderes dos juízes de declarar a inconstitucionalidade das leis, o seu exercício deve ser acomodado dentro da perspectiva do constitucionalismo e da democracia. Os direitos imunizados no texto constitucional devem ser compreendidos como vedações à subjugação material dos cidadãos por parte dos agentes públicos. Sendo assim, não é qualquer lei que tanja aspectos constitucionais que pode vir a ter sua inconstitucionalidade declarada, mas apenas aquelas que efetivamente interfiram na capacidade soberana de julgamento dos indivíduos. O controle de constitucionalidade substantivo deve ser realizado com o fito de impedir que direitos fundamentais sejam abolidos ou restringidos de maneira arbitrária, o que significa reconhecer que o Parlamento tem amplo espaço de conformação para adotar uma dentre as várias concepções de direitos legítimas.

Em uma sociedade plural, em que seus membros discordam profundamente sobre temas morais, os contornos dos direitos devem ser delineados por meio de um processo político de deliberação democrática. Somente nos casos em que a concepção legislativa adotada não preenche os requisitos mínimos de nenhuma concepção de direitos consistente, ou seja, quando se tratar de uma legislação de cunho autoritário ou preconceituoso, é que se mostra possível a intervenção judicial para sanar o deslize dos representantes políticos. Tais situações devem ser excepcionalíssimas. A declaração de inconstitucionalidade de um ato normativo deve ser encarada pelos agentes públicos como uma reprovação grave que merece maiores reflexões e cautelas tanto por parte dos cidadãos quanto pelos políticos, e não como algo ordinário e banal. 
Se mesmo depois de adotadas todas essas cautelas, ainda se entender estar diante de uma hipótese singular em que é necessário adotar uma interpretação substancial inovadora, qual o tipo e a forma do argumento moral compatível com o Estado de Direito? Em quais circunstâncias a autoridade legal conferida pela Constituição aos juízes de aferir a constitucionalidade das leis mostra-se legítima? Em uma sociedade democrática, qualquer imposição unilateral de preferências é considerada algo inadequado. Ao afastar a aplicação de uma lei, o magistrado não pode se basear em sentimentos pessoais sem a pretensão de validade geral, mas deve guiar-se por um juízo imparcial de correção ${ }^{12}$ que demonstre que a legislação adotada não é coerente com os princípios morais subjacentes à prática jurídica como um todo, bem ao estilo dworkiano. Waldron explica essa atitude interpretativa exigida por Dworkin da seguinte forma:

De vez em quando falamos sobre julgamentos valorativos como se fossem simples preferências. Mas não há nada de simples nos julgamentos valorativos requeridos pelos juízes de Dworkin. Nos casos fáceis, eles podem até não ser controvertidos; eles podem se parecer mais com o senso comum do que com filosofia moral. Mas nos casos difíceis - casos em que o direito existente é muito escasso (ou muito abundante) ou nos quais os precedentes ou textos são controvertidos ou ambíguos - a mistura de Dworkin entre filosofia moral e jurídica torna-se importante. É nesse momento que o juiz deve entrar em contato com seu Kant interior ou seu Rawls interior. "Você não pode pensar acerca da resposta correta para questões jurídicas", escreve Dworkin, "a menos que você já tenha refletido através de um vasto sistema teórico de princípios complexos"13.

O que restringe o juízo dos magistrados, por conseguinte, são os princípios de moralidade política que informam o modo apropriado como o Estado deve se relacionar com os cidadãos ${ }^{14}$. Os princípios indicam uma ordem prioritária de valores já adotada pela

${ }^{12}$ David Richards (1979a, p. 181-184) diferencia o agir moral imparcial daquele inadequado para a realização de análises morais da seguinte forma: "People express moral beliefs all the time, often reflecting existing conventions or, in general, expressing highly personal sentiments not seriously intend to have more general validity. However, a certain class of moral beliefs which are expressed as considered judgments has a special authority when, in making such judgments, we subject ourselves to the ideals conditions previously discussed so as to exclude internal distorting conditions of illness or private pique and contextual factors of personal interest, and the like. We think of moral judgments of such kind of being morally impartial or objective in a way in which others judgments are not. We give less weight to assumedly moral judgments which reveal unreflective bias, or class or self-interests, and correspondingly greater weight to judgments which are more free of personal idiosyncrasy and engaged with critical constraints of moral discourse. (...) Thus, the form of impartiality required for our considered ethical judgments is a kind of abstraction from one's personal tastes and background idiosyncrasies which enables one to see people not in terms of such morally irrelevant stereotypes or factors, but in terms of their fundamental moral equality as persons".

13 Tradução livre de WALDRON, 2006, p. 4-5.

${ }^{14}$ Dworkin (2003, p. 7) explica que as questões constitucionais se resumem basicamente em decidir qual o modo apropriado que o Estado deve tratar os seus cidadãos: "[T]he moral issues at the heart of both administrative and constitutional adjudication are largelly matters of political morality rather than individual ethics. The 
comunidade personificada em outros compromissos institucionais. Sua identificação decorre de uma reconstrução do material jurídico em que os valores inerentes a cada ato normativo e decisão judicial são resgatados pelo intérprete ${ }^{15}$. É na projeção dessa ordem de valores ao caso concreto que se torna possível a promoção de modificações no material jurídico existente, sem que o intérprete imponha sua preferência valorativa. Esses princípios, por determinarem direitos, funcionam como trunfos contra a vontade da maioria, que tem a obrigação moral de se manter coerente com princípios anteriormente adotados ${ }^{16}$. As noções de integridade e de equilíbrio reflexivo exigem exatamente que o Estado adote os mesmos princípios legitimadores de sua prática em todos os seus atos. Pode-se dizer, nesse sentido, que o respeito ao Estado de Direito corresponde à adoção desses princípios aos órgãos públicos que aplicam as normas jurídicas aos casos concretos.

O dilema entre estabilidade e mudança deve ser resolvido a partir de uma reflexão em que se analisa de maneira global se a declaração de inconstitucionalidade de uma lei servirá mais ao propósito de tratar os cidadãos com dignidade do que o respeito à legalidade e à democracia. Tem que ser demonstrado que a aplicação de determinada norma comprometerá de tal forma a autonomia dos cidadãos que: a) de nada lhe adiantarão as proteções do Estado de Direito; e b) a reversão dessa situação no plano democrático, em razão da manipulação das condutas decorrentes do próprio ato normativo, se tornará algo muito difícil ou improvável. Satisfeitas essas condições, o juiz deve articular um argumento de princípio para declarar a

issues of fairness that occupy ordinary adjudication are matters of how individuals should treat one another in business, or in creating risk and compensating for damages, for example. But the issues for judges in constitutional cases are about how government should or may treat its citizens".

15 David Richards (1977, p. 1098-1099) descreve a dificuldade encontrada na formulação de argumentos de princípios da seguinte forma: "[T] he capacity to formulate and apply principles is one of notorious difficulty both in the law and in ordinary life. Judges, like ordinary men, often have practical wisdom, i.e., mastery in the sophisticated and correct application of principles to problems of ordinary life, but nonetheless have great theoretical problems in giving principles any kind of exact formulation. (...) Legal principles may emerge only after a long process of judicial trial and error involving a number of disparate fact patterns and repeated attempts by a number of judges to articulate and refine the strand of acceptable principles that unites those patterns. (...) Legal principles are, after all, legal; in order to be binding, they must be implicit in past judicial tradition and practice, inferable by the usual methods of legal reasoning by analogy".

${ }^{16}$ A forma como se desenvolve a interpretação construtiva no pensamento de Dworkin é assim resumida por David Richards (1983, p. 736): "Dworkin suggests that judges, whether involved in statutory, common law, or constitutional interpretation, use a method of principle (as opposed to policy) whereby they excavate from previous case law the applicable principle of law and apply it to the novel, hard case. This method has two tests: the first is one of 'fit'. The principle used in the hard case must fit the data of the other cases, explaining their holdings arrived at in the hard case. Second, in many hard cases the available precedents will be inconsistent, ambiguous; therefore the fit criterion will not always work. The judge must then appeal to background rights, more general rights which both explain and organize many more particular rights throughout the legal system, and which have normative appeal as good arguments for rights. In the light of such rights, the previous case law may be reinterpreted, realigned, trimmed, and sometimes overruled in the interest of a deeper theory of law which the judge has managed to construct"'. 
inconstitucionalidade material de uma lei, reconduzindo sua decisão aos direitos fundamentais positivados.

Em resumo, o elemento da sistematicidade do Estado de Direito exige que os juízes, no exercício da jurisdição constitucional substantiva, utilizem argumentos de princípios, demonstrando como a ordem de valores adotada pode ser encontrada nos demais compromissos institucionais assumidos pela sociedade personificada, além de justificar o porquê e em que medida os valores da legislação afastada não são ou não podem preservados pela legalidade e pela democracia, devendo fundamentar sua decisão de acordo com as cláusulas constitucionais pertinentes.

O modo como o Neoconstitucionalismo utiliza a interpretação constitucional viola o elemento da sistematicidade do Estado de Direito em quase todos os aspectos delineados, a começar pela visão instrumental dada à jurisdição constitucional: enquanto no Estado de Direito a mudança não é vista como algo trivial pelos atores jurídicos, o Neoconstitucionalismo baseia-se primariamente na ideia de emancipação social pelo Direito. Como consequência dessa atitude, passa-se a enxergar as normas constitucionais não como limites à atuação jurisdicional, mas como um convite à interpretação inovadora que possa redefinir os próprios contornos dos compromissos constitucionais. Os autores neoconstitucionais, portanto, não se preocupam com a dignidade do Estado de Direito ou da legislação, partindo do pressuposto de que a autorização legal para exercer o controle de constitucionalidade permite que, mencionado o texto constitucional, afaste-se qualquer lei ou ato administrativo, sem maiores constrangimentos.

A situação se torna mais crítica com a introdução da ponderação e dos princípios da razoabilidade e da proporcionalidade na argumentação jurídica, pois esses instrumentos permitem que o intérprete manipule os valores constitucionais de acordo com a sua preferência. A partir de então, não só os argumentos de princípios são considerados válidos, mas também os argumentos de política, o que faz com que a atividade jurisdicional se torne algo muito mais discricionário do que se espera em um Estado de Direito. Ademais, o efeito irradiador do chamado fenômeno da constitucionalização do direito transforma toda questão jurídica em questão constitucional, possibilitando que em qualquer caso o magistrado exclua a aplicação de normas jurídicas que discordem do conteúdo. Esses últimos elementos aproximam a doutrina neoconstitucional do pragmatismo jurídico, já que os inúmeros valores constitucionais existentes possibilitam adotar praticamente qualquer decisão. Em sentido semelhante pondera Elival da Silva Ramos: 
Como já foi dito, a maior parte dos escritos nacionais associados ao ideário do neoconstitucionalismo contemplam manifestações de um difuso moralismo jurídico e, nesse sentido, constituem fator de impulsão ao ativismo judicial. (...) A principiologização do direito (...) desponta como a face mais visível desse pretenso "pós-positivismo" tupiniquim, abrindo as portas do sistema jurídico ao subjetivismo de decisões judiciais que, valendo-se dos contornos menos nítidos das normas-princípios e potencializando-lhes os efeitos para além do que seria lícito fazer, deixam de concretizar a Constituição para, a bem de ver, construí-la, ao sabor das preferências axiológicas de seus prolatores ${ }^{17}$.

O efeito pernicioso da difusão das teses neoconstitucionais é que, em virtude dessa perda de parâmetro, os juízes passam a acreditar que qualquer interpretação judicial é possível. Substituem-se as razões jurídicas pelas razões dos magistrados por meio de uma ostensiva revisão judicial do mérito dos atos estatais em que qualquer argumentação valorativa é válida para se ingressar na dimensão da justificação e adotar uma interpretação inovadora. Isso, no entanto, representa uma absoluta descaracterização do uso de normas jurídicas como parâmetros decisórios, retirando qualquer possibilidade de compreensão racional do formato dos argumentos judiciais por parte dos cidadãos, vulnerando-se, assim, a ideia de Estado de Direito.

\section{4 - Estado de Direito e jurisdição constitucional: uma Constituição modesta}

O objetivo desta pesquisa era testar as teses do Neoconstitucionalismo a partir da reconstrução conceitual do Estado de Direito, e não desenvolver uma exaustiva teoria da interpretação constitucional. Os temas abordados ao longo do texto, contudo, deixaram latentes impressões sobre o modo como a jurisdição constitucional deve ser exercida por quem leva o Estado de Direito a sério. O escopo deste último tópico é dar formatação global aos argumentos até aqui desenvolvidos, esclarecendo pontos e semeando ideias que poderão ser trabalhadas em maior extensão em textos futuros.

Ao se elaborar um ponto de vista normativo acerca do controle jurisdicional de constitucionalidade, a primeira questão a se elucidar diz respeito à concepção de Constituição adotada pelo intérprete. A concepção aqui adotada pode ser inferida de algumas das teses defendidas. Um argumento recorrente no presente texto foi o de que o Estado de Direito consiste na intermediação das relações entre os sujeitos e o poder público por meio de normas jurídicas, elaboradas por um processo político- democrático, cujo conteúdo seja acessível

\footnotetext{
${ }^{17}$ RAMOS, 2010, p. 285.
} 
pelos destinatários e que sirvam elas de guias de conduta para os cidadãos e de parâmetros decisórios para os magistrados. As normas constitucionais, nesse sentido, tornam-se relevantes na medida em que consigam servir como razões de segunda ordem que efetivamente excluam razões de primeira ordem dos destinatários.

A concepção neoconstitucional, por outro lado, ainda ressonando as teses do constitucionalismo dirigente, defende que as relações intersubjetivas devem ser mediadas primordialmente pelos valores e princípios constitucionais, que demandam considerações morais para sua compreensão. O que se ponderou, dentre outras coisas, é que, em uma sociedade plural, não havendo uma doutrina moral abrangente, a perspectiva neoconstitucional se mostra inadequada, não só por diminuir a certeza jurídica e aumentar a margem de discricionariedade dos agentes públicos, mas também por transferir às Cortes, em detrimento da política majoritária, a função de decidir sobre as principais questões coletivas. O ambicioso projeto neoconstitucional desconsidera a existência de desacordos morais na sociedade e a dignidade intrínseca da legislação. Para que haja uma revalorização da política como locus privilegiado na definição das políticas públicas endossadas pela sociedade tornase necessário abandonar as concepções constitucionais totalizantes. É preciso, pois, desmistificar a ideia de que a Constituição possui as respostas para todos os problemas da sociedade, adotando-se o que Frederick Schauer denominou de Constituição modesta:

Há ainda outra visão da Constituição, uma que é bem mais modesta. A Constituição, embora estabeleça a estrutura básica do governo e delineie as regras procedimentais que devem ser observadas pelo governo, preceitua notadamente muito pouco sobre como o governo deve agir, e assim é que deve ser. Em geral, essas decisões substantivas centrais sobre políticas públicas devem ser feitas em fóruns mais públicos, mais representativos e mais deliberativos, sejam esses fóruns as casas parlamentares ou as mais importantes e mais difusas redes de contato pelas quais a opinião pública é formada, reformada e implementada. Para todas essas tarefas, a função apropriada da Constituição modesta é a de um mero espectador. Acreditar em uma Constituição modesta não significa discordar com o constitucionalismo popular sobre o locus primário para a determinação das grandes questões de política pública. Significa, em vez disso, discordar da noção de que quando essas questões são determinadas pelo povo o debate deve ou deveria ser canalizado através da Constituição. Há casos em que certamente ele é, mas da mesma forma que o dono de um martelo precisa ter cautela ao enxergar todo problema como um prego, da mesma forma, um constitucionalista (...) ter cautela ao enxergar todo problema como constitucional $^{18}$.

${ }^{18}$ Tradução livre de SCHAUER, 2004, p. 1065. 
Partindo da perspectiva de um constitucionalismo modesto, a prática constitucional passa a ser justificada primordialmente por fornecer uma plataforma institucional estável que assegura a coordenação das condutas e que permite a formação da vontade política da sociedade. O principal propósito da jurisdição constitucional é delimitar as competências de cada órgão estatal, inclusive do Poder Legislativo, e fiscalizar para que esses limites não sejam usurpados por parte dos agentes públicos. Isso significa reconhecer que o legislador tem ampla margem de conformação para adotar uma dentre as várias concepções razoáveis de direitos. Somente nos casos excepcionais, em que o Parlamento extrapole os seus limites e adote leis que claramente subjuguem os cidadãos, ou seja, leis absolutamente injustas, é que o Poder Judiciário estaria autorizado a intervir.

Não se está defendendo uma interpretação pura do Direito, desvinculada da moral. Não é disso que se trata. Adota-se, aqui, uma interpretação construtiva em que se reconhece que o tratamento digno por parte do Estado é o principal propósito da prática jurídica, o que deve ser observado não apenas no conteúdo das decisões, mas também no modo como as pessoas são tratadas na utilização das normas jurídicas em seu cotidiano. O Estado de Direito é um dos meios pelos quais se protege a dignidade humana, o que deve ser levado em consideração pelo intérprete. Nesse sentido, a interpretação aqui adotada é eminentemente moral. Busca-se apresentar a melhor versão da prática jurídica considerada como um todo, o que deve incluir considerações sobre o Estado de Direito e a dignidade da legislação. A constatação é a de que o tributo à moralidade intrínseca desses conceitos exige que os juízes não ingressem na argumentação constitucional quando não for absolutamente necessário, o que demanda uma análise cautelosa das justificativas substantivas que embasam cada situação específica em que a inconstitucionalidade de um dispositivo legal é arguida.

Há, no modelo aqui desenvolvido, basicamente duas situações que podem desencadear o exercício da jurisdição constitucional ${ }^{19}$ e que demandam justificativas distintas, não sendo possível resumir a questão da legitimidade em apenas um dos quatros argumentos de legitimidade mencionados no capítulo 1 . Na verdade, o balizamento adequado do tema envolve a harmonização de todos aqueles argumentos, pois as hipóteses que autorizam a revisão judicial são complexas, normalmente acoplando mais de uma justificativa. Tampouco

\footnotetext{
${ }^{19}$ Frederick Schauer (2004, p. 1066) aduz três hipóteses em que o exercício da jurisdição constitucional seria justificada para i) proteger interesses que são sistematicamente sub-representados; ii) restringir os interesses (razões de primeira ordem) que devem ser levados em consideração na tomada de decisões políticas; e iii) resolver os problemas de coordenação do dilema dos prisioneiros. Na presente abordagem, os itens I e III serão destacados como hipóteses especiais de controle de constitucionalidade, enquanto o item II será tratado como uma característica genérica das normas jurídicas de funcionarem como razões de segunda ordem e que também se aplica às normas constitucionais, conforme ressalva a ser feita no próximo parágrafo.
} 
é possível dizer que o argumento da proteção de direitos seja o preponderante. Como visto, o respeito à dignidade humana é uma ideia intrínseca às noções de Estado de Direito e de democracia majoritária. Defender que os juízes estariam autorizados a declarar a inconstitucionalidade de leis sempre que houvesse restrição tolerável a um direito seria o mesmo que ignorar essa faceta moral desses conceitos.

Antes de prosseguir na construção do modelo decisório, é necessário um esclarecimento. A Constituição, por consubstanciar-se em norma jurídica advinda de um processo político legítimo, também merece ter a sua dignidade reconhecida. Assim, as normas constitucionais devem ser compreendidas como razões de segunda ordem que excluem as demais considerações pessoais do intérprete, obrigando à sua observância ${ }^{20}$. Havendo uma situação de clara incidência de uma regra constitucional, não há alternativa senão aplicá-la, o que significa dizer que as normas de alta densidade semântica apresentam razões jurídicas que não podem ser ignoradas ou ponderadas pelos magistrados. $\mathrm{O}$ art. $109, \S 2^{\circ}$, por exemplo, que dispõe que as ações intentadas contra a União podem ser ajuizadas no Distrito Federal, não pode ser afastado por norma infralegal que disponha o contrário ${ }^{21}$. Do mesmo modo, o art. 16, que preceitua que o processo eleitoral somente pode ser modificado até um ano antes do pleito impede que legislações editadas em prazo inferior ao determinado tenham sua validade reconhecida com base em princípios constitucionais. A Constituição Federal não deve ser lida em tiras, mas também não permite leitura contra legem.

Ocorre que há cláusulas constitucionais que, em razão de sua abstração, não fornecem nenhuma ou quase nenhuma diretriz interpretativa, como é o exemplo do direito à liberdade, à igualdade e à dignidade humana ${ }^{22}$. Há outros casos em que a Constituição alberga princípios

${ }^{20}$ É importante ressaltar que não só as leis oferecem razões de segunda ordem, mas práticas consolidadas, súmulas e precedentes também exercem essa função. Uma reorientação no entendimento da Corte nessas questões com base em argumentos constitucionais implica mudança no material jurídico sujeita a restrições semelhantes à declaração de inconstitucionalidade de uma lei.

${ }^{21}$ Esse entendimento tem sido adotado pelo Tribunal Regional Federal da $1^{\text {a }}$ Região ao extinguir as ações coletivas ajuizadas na Seção Judiciária Federal do Distrito Federal com base no art. 2-A, da lei 9.494/97, que restringe a eficácia jurídica das sentenças à base territorial em que foi proposta a ação, ignorando que a Constituição conferiu, no $\S 2^{\circ}$ do art. 109, jurisdição nacional ao foro do Distrito Federal. Por todos, cf. Tribunal Regional Federal da $1^{\text {a }}$ Região, Apelação Cível nº. 2001.34.00.010797-2 / DF, Rel. Des. Neuza da Silva, julgado em 16/10/2009, publicado no DJe de 16/11/2009.

22 A ausência de fornecimento de parâmetro normativo no uso desses direitos, principalmente o da dignidade humana, tem sido reportada até mesmo pelos neoconstitucionalistas. Paulo Schier (2005, p. 18), um dos precurssores do Neoconstitucionalismo no Brasil, afirma, em tom crítico, que "a doutrina brasileira tem assistido a um processo, nem sempre saudável, emq eu todas as questões jurídicas vêm sendo reportadas à dignidade da pessoa humana. Isso tem gerado, reitere-se, uma compreensão inadequada da chamada dogmática constitucional principialista, eis que, por certo, nem tudo pode ser reconduzido aos princípios e, até mesmo, ao princípio da dignidade da pessoa humana. (...) O discurso da dignidade da pessoa humana tem sido responsável, pela sua inadequada compreensão e utilização, por colocar certas categorias constitucionais onde, muitas vezes, elas não são cabíveis. O princípio da dignidade humana tem sido apontado, por isso, não raro, como panacéia para a resolução de problemas jurídicos nem sempre 
conflitantes que a priori se anulariam, como é o caso do princípio da livre concorrência e o da proteção ao consumidor. Nessas situações, é impossível afirmar que a Constituição tenha assumido uma posição clara que possa servir de critério para o controle de constitucionalidade. Caso se permita apelar diretamente a essas noções para afastar a aplicação de leis, nada estará imune ao crivo do Poder Judiciário ${ }^{23}$. Não se trata negar a força normativa do texto constitucional, mas reconhecer que essas cláusulas em si não fornecem qualquer argumento de princípio que sirva de parâmetro. É nessas hipóteses que se exige uma atuação judicial mais cautelosa, a fim de se evitar que todas as decisões políticas da sociedade sejam transformadas em questões constitucionais. Abaixo serão traçadas algumas diretrizes sobre o tema.

Retornando às duas hipóteses de exercício do controle de constitucionalidade, a primeira relaciona-se com a necessidade de estabilização das expectativas quanto ao preenchimento dos requisitos legais para que uma lei seja considerada válida. Nessa categoria enquadram-se os juízos de inconstitucionalidade estrutural, seja na apreciação do conflito de competência entre órgãos públicos ou entre entes federativos, seja na verificação quanto à correta observância do processo legislativo na elaboração de uma lei. A justificativa que confere autoridade às determinações judiciais nesses casos é a mesma que confere autoridade ao Estado de Direito em geral, qual seja, a necessidade de coordenação. De fato, não só os cidadãos necessitam de organização para que os resultados sociais almejados sejam atingidos. Os agentes políticos, os órgãos estatais e os entes federativos também podem eventualmente extrapolar os limites de suas competências constitucionais e minar o projeto social coletivo, exigindo-se, assim, o estabelecimento de mecanismos de controle e repressão.

Para o constitucionalismo modesto, o argumento da competência funcional parece conferir uma justificativa adequada para que essa tarefa seja exercida pelo Poder Judiciário. Como visto, a "escola do Legal Process" advogava que as funções estatais deveriam ser atribuídas àqueles órgãos que possuíssem as melhores capacidades para decidir determinadas questões. Por ser um ente desinteressado e politicamente neutro, o Supremo Tribunal Federal

complexos, onde a simples incidência ou aplicação das regras infraconstitucionais, mediante aplicação da velha lógica da subsunção, seria suficiente para uma adequada resposta jurídica".

${ }^{23}$ Essa a posição de Manoel Gonçalves Ferreira Filho (2009a, p. 395) para quem: "Num Estado de Direito, num sistema democrático - num Estado Democrático de Direito, no sentido que dá à expressão o art. $1^{\circ}$, caput, da Lei Magna em vigor -, organizado segundo a separação de poderes, é indiscutível que essa densificação (o desdobramento em regras do princípio) compete ao legislador. Realmente, o primeiro princípio do Estado de Direito é o de legalidade”. 
aparenta ser a instituição mais bem aparelhada para desempenhar essa tarefa ${ }^{24}$. No exercício dessa função, seria interessante que a Corte adotasse uma nova postura, aprofundando-se no estudo sobre as consequências advindas da adoção das diversas interpretações possíveis ${ }^{25}$. Sugere-se, assim, que essas ocasiões sejam mais bem aproveitadas pelo tribunal para que se produzam os melhores resultados sociais. A requisição de estudos técnicos sobre os impactos da adoção das diferentes abordagens possíveis e a oitiva daqueles potencialmente afetados pela declaração de inconstitucionalidade seriam medidas que poderiam ser adotadas ${ }^{26}$.

A segunda hipótese relaciona-se ao controle de constitucionalidade do conteúdo substantivo das leis. Nesses casos, a autoridade da decisão reside no caráter simbólico da injustiça do ato aprovado pelo Parlamento. Ou seja, é a própria argumentação moral utilizada na decisão que a legitima. A justificativa dessa espécie de controle exige um sincretismo dos argumentos da vontade popular, procedimental e da proteção de direitos (cap. 1).

Como já dito na Tese, em uma sociedade democrática e plural parece que somente em situações graves, em que uma lei esteja efetivamente comprometendo a autonomia de parcela dos cidadãos de tal forma que o bom funcionamento do ordenamento jurídico reforçará ainda mais a situação de impotência, é que o exercício da jurisdição constitucional com base no argumento de proteção de direitos se torna legítimo. Mesmo nessas situações, sugere-se que o intérprete tenha o cuidado de demonstrar que os afetados pelo ato normativo não foram devidamente representados na esfera política, seja em razão de preconceito ou de vício do processo democrático. Em suma, deve-se demonstrar que o grupo prejudicado pela medida está sistematicamente saindo perdedor na arena política e que, por isso, merece uma proteção

\footnotetext{
${ }^{24}$ Em sentido contrário, confira as críticas de Adriene Stonne em seu artigo Judicial review without rights: some problems for democratic legitimacy of structural judicial review (2008), afirmando que o Senado Federal, por representar a Federação e ter seus membros eleitos, teria mais legitimidade para desempenhar essa função.

${ }^{25}$ Um exemplo simples pode demonstrar esse ponto. A Constituição Federal de 1988 confere à União Federal a competência para legislar sobre trânsito e transporte (art. 22, XI), ao passo que delega aos municípios a competência para legislar sobre assuntos locais, além de organizar e prestar o transporte coletivo local (art. 30, I e IV). Pois bem, em certos locais, como no Distrito Federal, o transporte "pirata" tornou-se um problema de política pública. Ocorre que o Código de Trânsito Brasileiro prescreve penas muito brandas para aqueles que promovem essa prática, o que tem incentivado cada vez mais o transporte "pirata" na capital do país. Preocupados com essa situação, os deputados distritais aprovaram a lei $n^{\circ}$. 239/92, que impõe sanções mais severas aos infratores que burlam o serviço de transporte público. Não obstante a particularidade do serviço público local, o Supremo Tribunal Federal vem declarando sistematicamente a inconstitucionalidade de leis similares à do Distrito Federal. Caso houvesse uma análise mais refletida sobre esse problema, poderia haver uma guinada jurisprudencial justificada sobre o assunto, passando a considerar essa espécie de legislação como regulação de transporte público. Para uma decisão do Pretório Excelso declarando a inconstitucionalidade dessa lei distrital em controle difuso, cf. Supremo Tribunal Federal, Agravo de Instrumento ${ }^{\circ}$. 798.594, Rel. Min. Luiz Fux, julgado em 13/04/2011, publicado no DJe de 25/05/2011.

${ }^{26}$ A necessidade e relevância de estudos técnicos para auxiliar na formação do juízo acerca da constitucionalidade das leis foram desenvolvidas em certa extensão por Gilmar Mendes ao tratar da análise fatos e prognoses no exercício da jurisdição constitucional, cf. MENDES, G., 1999.
} 
constitucional especial ${ }^{27}$. Nesse ponto, é recomendável que o intérprete desenvolva uma fundamentação típica do argumento procedimental que afaste a presunção de dignidade da legislação.

O que parece ser importante nessa análise substantiva é que a argumentação do intérprete não se baseie exclusivamente em um juízo de reprovação moral. Como defendido, a mera menção a uma série de valores e princípios abstratos não se mostra suficiente para legitimar uma decisão constitucional. A saída para o enfrentamento dessas questões parece estar na contextualização da decisão dentro do enredo histórico-político, demonstrando que não obstante haver bons motivos para inferir nos compromissos políticos já assumidos pela sociedade os princípios que subsidiam o pedido, o processo político majoritário por alguma razão inidônea está impedindo o reconhecimento do direito ${ }^{28}$.

É nesse ponto que o argumento da vontade popular ganha relevância. Não se trata de defender a adoção de pesquisas de opinião como parâmetros decisórios. A atitude interpretativa bem-vinda é aquela que leva a sério os diversos sinais institucionais de mudança de entendimento dos compromissos constitucionais. Em uma democracia, a legislação não deve ser encarada como algo arbitrário e fruto do acaso, mas como uma decisão política que merece respeito por simbolizar o esforço coletivo para se adotar um posicionamento comum em meio aos persistentes desacordos. A compreensão do contexto político que levou à edição de determinadas leis e emendas constitucionais revela elementos estruturais da sociedade que vinculam a interpretação constitucional. Na elaboração de uma interpretação constitucional inovadora parece ser importante que o intérprete consiga identificar quais são os gargalos políticos que estão impedindo que as leis estejam em consonância com os anseios da população. O exercício de compreensão da evolução do contexto histórico-político-cultural com o intuito de traduzir esses fenômenos na linguagem de direito constitucional parece

\footnotetext{
${ }^{27}$ Frederick Schauer (2004, p. 1057-1058) argumenta, de modo semelhante, que a proteção aos direitos fundamentais faz mais sentido com relação à proteção de pontos de vista impopulares, que dificilmente ganharão espaço na arena democrática: "The importance of external constraint is especially apparent in the contexto of the protection of persistently unpopular and systematically under-represented interests - not only the discrete and insular minorities of the Carolene Products footnote, but also those whose unpopularity spans traditional ideological divisions (atheists, flag burners, child pornographers, and those charged with crimes, for example). With respect to such individuals, their rights will probably never be seriously represented by popular or legislative majorities, and it should be no surprise that the rights these minorities claim are those for which judicial supremacy has made the greatest difference".

28 Em artigo publicado na década de 1950, Robert Dahl (1957, p. 293-295) já afirmava que o papel da Suprema Corte na criação de políticas públicas só ocorre quando há mais ou menos um consenso formado entre os agentes públicos sobre determinado tema, mas não há uma coalizão política estável para formar uma maioria que endosse essas reivindicações. Ou seja, não basta que se formule uma crítica eminentemente moral para que a Corte atue; é necessário que haja condições político-culturais para a implementação da política pública almejada.
} 
fornecer um terreno fértil para a densificação do conteúdo das cláusulas constitucionais vagas e evitar a banalização de seu uso ${ }^{29}$.

Ao contrário do defendido pelos neoconstitucionalistas, que veem nos direitos fundamentais - e nos princípios - instrumentos que possibilitam uma interpretação mais maleável, para um adepto de um constitucionalismo modesto essas cláusulas parecem exigir, na verdade, um esforço hermenêutico muito maior de densificação que é limitado tanto pelo contexto histórico em que a decisão está inserida quanto pelo uso de argumentos de princípios. Uma interpretação inovadora tem de partir de uma reconstrução interpretativa do próprio ordenamento jurídico para extraírem-se os princípios que indicam a ordem prioritária de valores adotada pela comunidade personificada em outros compromissos políticos já assumidos.

Considera-se, assim, que a utilização de argumentos de política e da ponderação de valores deve ser evitada ao máximo para que o intérprete não imponha suas preferências valorativas na sociedade. Isso significa que uma interpretação constitucional que tenha como principal objetivo a redistribuição de renda pela via judicial dificilmente pode ser reconciliada com uma teoria que leve a ideia de Estado de Direito a sério. O modo como deve ser distribuída a renda e quais devem ser os beneficiados e os prejudicados pela medida são decisões valorativas que variam de acordo com os matizes políticos de cada um. Na ausência de uma diretriz jurídica que dê vida a um sistema de justiça social, dificilmente haverá um princípio de moralidade política universalizável que possa ser invocado pelo magistrado para basear uma decisão judicial desse tipo. Na maioria das vezes, a decisão será baseada em valores pessoais, o que parece estar em desacordo com a ideia de Estado de Direito. Quando o Judiciário atua nesses casos, sua decisão é mais simbólica do que efetiva, tornando-a problemática $^{30}$.

Nesse sentido, a concretização dos direitos sociais e econômicos pela via da interpretação constitucional também é uma questão complicada. Não por outro motivo, o status jurídico desses direitos é descartado por Dworkin, que os considera apenas como direitos políticos. A possibilidade de conferir efetividade a um direito de segunda geração, como o direito à saúde, por meio de uma argumentação judicial de princípio, no entanto, não

\footnotetext{
${ }^{29}$ Como exemplo de obras de direito constitucional que procuram analisar a evolução do contexto históricocultural para compreender o atual sentido dos compromissos constitucionais, cf. ACKERMAN, 2007; BALKIN, 2011; POST, 1995.

${ }^{30}$ Certamente o Poder Judiciário pode desempenhar um papel político significativo na sociedade. O que se tem argumentado é que essa atuação normalmente fragiliza o conceito de Estado de Direito, o que em longo prazo irá trazer mais malefícios do que benefícios para a sociedade, como vem ocorrendo com o Neoconstitucioanlismo.
} 
está descartada, mas exigiria um desenvolvimento teórico cauteloso, o que não é o escopo da presente $\mathrm{Tese}^{31}$. O que parece ser mais adequado a priori é que a efetivação desses direitos seja feita por meio de legislações que criem políticas públicas eficientes. O Poder Judiciário, ao dar concretude aos comandos jurídicos, pode ser partícipe dos projetos sociais - como ocorre na implementação dos diversos programas do Governo Federal, como o Bolsa Família - mas dificilmente pode exercer a função de protagonista.

Enfim, em um Estado de Direito, o controle de constitucionalidade deve se constituir uma exceção, sendo primordialmente utilizado para fins de coordenação e controle do funcionamento das instituições democráticas. Somente em situações extraordinárias é que os juízes estariam autorizados a reformar o material jurídico com base em argumentos substantivos, o que significa reconhecer que nem todas as questões jurídicas devem ser tratadas como questões de estatura constitucional. O fetiche do Neoconstitucionalismo pelo Poder Judiciário revela no fundo um desconforto com a democracia, na feliz expressão de Mangabeira Unger ${ }^{32}$. Adotar uma concepção constitucional modesta é medida imperiosa para que haja o devido respeito ao Estado de Direito e à reabilitação da política como locus decisório privilegiado em uma democracia.

\footnotetext{
${ }^{31}$ Para uma análise sobre os limites e potenciais da atuação judicial na implementação de políticas públicas por meio da concretização dos direitos sociais, cf. LOPES, 1994.

32 "O desconforto com a democracia se evidencia em todas as áreas da cultura jurídica contemporânea: na identificação incessante de limitação à regra da maioria, em vez de restrições ao poder de minorias dominantes, como a responsabilidade de juristas e magistrados; na consequente hipertrofia da prática e estruturas contrárias à regra da maioria; na oposição a toda reforma institucional, principalmente aquelas concebidas para elevar o nível de engajamento político popular, como ameaças ao sistema de direitos; na identificação dos direitos de propriedade com direitos de divergir; no esforço para obter de juízes, sob o pretexto de aperfeiçoar a interpretação, os avanços que a política popular não consegue produzir; no abandono da reconstrução institucional a momentos raros e mágicos de recriação nacional; na atenção concentrada em juízes superiores e no seu processo de seleção como a parte mais importante da política democrática; num ideal de democracia deliberativa que se torna mais aceitável quanto mais próximo fica, em estilo, de uma conversa cortês entre cavalheiros numa sala de visitas no século XVIII; e, às vezes, no tratamento explícito da política partidária como fonte subsidiária e derradeira da evolução jurídica, a ser tolerada quando nenhum dos métodos mais sofisticados de resolução jurídica de controvérsias se aplica". (UNGER, 2004, p. 95-96).
} 


\section{Conclusão}

O Neoconstitucionalismo já está nas ruas. Acadêmicos, magistrados e alunos debatem suas teses com a mesma naturalidade com que discutem a interpretação de um artigo do Código Civil. Brada-se a independência dos formalismos de outrora. Argumenta-se que os princípios jurídicos e a ponderação libertaram os juristas das amarras legais que os subjugavam, possibilitando agora uma atuação mais proativa, com vistas a promover justiça social. Os estudos sobre arranjos institucionais, funcionamento da democracia e formas de aquisição e exercício do poder, antes relevantes para os teóricos de direito constitucional, cederam espaço a teorias da argumentação que utilizam o ponto de vista dos juízes constitucionais, como o caso central da prática jurídica.

É curioso que esse protagonismo dos tribunais não tenha proporcionado um maior interesse no estudo sobre o Estado de Direito. A rigor, uma ênfase maior no Poder Judiciário deveria desencadear um incremento nas pesquisas sobre o modo como as normas jurídicas restringem a discricionariedade dos agentes públicos e trazem previsibilidade e certeza para a vida dos cidadãos, focando-se no papel dos magistrados na promoção desses valores. Não foi bem isso que aconteceu. Quando se fala em legalidade, associa-se logo a um positivismo ultrapassado, uma compreensão limitada do fenômeno jurídico. Alega-se que os juízes, com seu senso moral aguçado, necessitam de maior flexibilidade para desenvolver suas capacidades emancipatórias. Leis e códigos? Isso tudo é coisa do passado. Interpretar a letra da lei? Nem pensar! O importante mesmo são os valores e os princípios constitucionais.

Como consequência dessa lógica, o trabalho dos neoconstitucionalistas tem sido basicamente o de desenvolver instrumentos que possibilitem uma atuação judicial mais expansiva e criativa. Hércules virou Zeus. Razoabilidade, proporcionalidade, constitucionalização do Direito, eficácia horizontal dos direitos fundamentais, derrotabilidade das normas jurídicas, força normativa da Constituição, sobreinterpretação constitucional, filtragem constitucional etc., são todas expressões que possuem em comum o fato de conferirem aos juízes um maior poder de interferência na realidade social. Normas e regras jurídicas fazem parte de um vocabulário antiquado. Fala-se agora em princípios, valores, fins, standards, conceitos jurídicos indeterminados, cláusulas gerais, enfim, toda matéria-prima que confere maior margem à manipulação dos resultados por parte dos intérpretes. A 
indeterminação dos textos legais é paradoxalmente festejada e admirada. Quanto mais abstrato, mais sentido tem. O que tem significado é que é insignificante.

Argumentou-se ao longo desta Tese que essa postura neoconstitucional produz um custo social muito alto, que não está sendo devidamente contabilizado por seus adeptos. A prática jurídica não se resume ao julgamento de casos de grande repercussão pelo Supremo Tribunal Federal. Os cidadãos utilizam as normas jurídicas em seu dia a dia, na intermediação de suas relações com outros cidadãos e com o Estado. O Direito está presente tanto no preenchimento do formulário de imposto de renda e na assinatura de um contrato de seguro de saúde, quanto no reconhecimento da constitucionalidade da união civil homoafetiva e da possibilidade do uso de células-tronco em pesquisas científicas. A imagem do magistrado analisando meticulosamente qual das interpretações possíveis produz o melhor resultado social não reproduz de maneira adequada todas as dimensões do fenômeno jurídico.

Na condução de suas vidas, os cidadãos dependem do Direito. E eles não desejam simplesmente aguardar de maneira passiva as decisões ex post factum dos agentes estatais sobre o modo apropriado de preencher o formulário fiscal ou quais são as doenças preexistentes que estão excluídas da cobertura de determinado seguro. Ao contrário, querem efetivamente participar da prática jurídica, compreendendo o significado das normas jurídicas, utilizando-as como guias de conduta e avaliando criticamente a conduta dos demais participantes a partir dos parâmetros normativos devidamente estabelecidos. Em suma, os cidadãos almejam ter uma atitude reflexiva crítica acerca dessa prática, compartilhando aquilo que Hart (1997, p. 56) denominou de aspecto interno do Direito. Para tal desiderato, entretanto, os cidadãos precisam ter o mínimo de conhecimento sobre como os agentes públicos irão interpretar as normas jurídicas. Somente antevendo as possíveis consequências da adoção de determinados atos é que o agente tem condições de decidir com autonomia a conduta a adotar.

O conceito jurídico que apreende com exatidão essa necessidade dos cidadãos de se situarem na prática jurídica como sujeitos autônomos que ditam os rumos de suas vidas é o de Estado de Direito. Conforme se demonstrou, a legalidade é o meio pelo qual o Estado trata os cidadãos com dignidade na utilização das normas jurídicas na intermediação da vida em coletividade, diferenciando-se de outros modelos de Estado que manipulam as condutas dos indivíduos por meio de ameaças e coerção. Pode-se dizer, assim, que o Estado de Direito é uma virtude ou qualidade moral presente em alguns regimes jurídicos que estabelecem um meio legítimo de proceder no uso e na aplicação das normas jurídicas. O Estado de Direito, portanto, refere-se à dignidade de tratamento, não de resultado. 
Alegou-se que, para servir a esse seu fim, o Estado de Direito exige, fundamentalmente, que as normas jurídicas sejam utilizadas de maneira efetiva como guias de conduta, que se disponibilizem procedimentos decisórios participativos e que os juízes, ao interpretar tais normas, decidam com base em argumentos jurídicos que possam ser aferidos racionalmente pelos demais membros da sociedade. No contexto, uma interpretação judicial inovadora que modifique o entendimento firmado nas normas e nas decisões anteriores, para ser considerada legítima, deve articular de maneira consistente os elementos presentes nos demais compromissos políticos já adotados pela comunidade no afã de demonstrar a existência de um princípio subjacente aos demais atos institucionais indicando uma ordem prioritária de valores que, por coerência, deve ser projetado ao caso em análise. Esse exercício hermenêutico faz-se necessário para que o juiz demonstre não estar impondo sua visão política sobre o assunto, mas sim julgando de acordo com as normas jurídicas válidas, permitindo que sua decisão seja avaliada de maneira crítica pelos demais participantes da prática jurídica. É o argumento de princípio, portanto, que justifica o trânsito entre as dimensões da adequação e da justificação da interpretação jurídica.

O Neoconstitucionalismo, contudo, em sua ânsia de reconstruir a teoria jurídica com fundamento em novos valores, relega a legalidade a segundo plano, passando a se importar primariamente com a substância das decisões. Tomando por base casos nos quais a sociedade viu-se transformada pelo Direito, como o Brown v. Board of Education, essa doutrina elabora um arsenal teórico que possibilita reproduzir as mesmas condições que desencadearam a emancipação social nesses casos simbólicos em todos os casos judiciais. Foca-se em mecanismos que possibilitam aos juízes realizarem revoluções sociais independentemente da política majoritária, o que obviamente só é possível se o Poder Judiciário não estiver subordinado às opções legislativas. Desenvolveu-se, então, uma teoria constitucional totalizante, que influencia o modo de ver de todas as demais normas do ordenamento jurídico, transformando toda questão jurídica em questão constitucional. Os instrumentos para tanto já são conhecidos: princípios, valores, fins, ponderação, direitos fundamentais etc. Esse passo faz com o Neoconstitucionalismo se distancie dos ideais do Estado de Direito, já que, por um lado, torna as normas jurídicas mais fluidas e indeterminadas, e, por outro, deixa a atividade jurisdicional menos previsível.

Não obstante a vasta formulação de mecanismos que conferem maior liberdade aos juízes, o Neoconstitucionalismo olvidou-se de desenvolver uma teoria normativa que indique como os juízes devem decidir os casos que agora lhes são apresentados livres das amarras 
formais ${ }^{1}$. Fala-se em reencontro com a moral, mas isso não é o bastante. Argumentou-se, na Tese, que toda interpretação é moral. Quando um formalista decide um caso sem se afastar do texto legal, está agindo assim porque entende que essa é a interpretação que melhor apresenta a prática jurídica como um todo. Da mesma forma, um originalista, ao tentar buscar o sentido original dado às cláusulas constitucionais por aqueles que promulgaram a Constituição, assim o faz por considerar que esse é o modo mais legítimo de lidar com o conteúdo indeterminado do texto constitucional. Essas são opções eminenentemente morais. Cada intérprete impõe valores à prática jurídica que norteiam todas as suas interpretações subsequentes, ditando, assim, o conteúdo de sua concepção jurídica. Ao se perguntar quais valores alimentam a concepção neoconstitucional, contudo, encontra-se um vazio. Não há uma agenda definida. Às vezes o viés é liberal, outras vezes é social. De vez em quando se valoriza a eficiência, em outras a redistribuição de renda.

O Neoconstitucionalismo encontra-se, então, em uma encruzilhada. Enquanto pretensão apresenta-se como um discurso totalizante, sendo um descendente direto do constitucionalismo dirigente, cujo objetivo era preparar a transição para o socialismo. A ausência de um substrato normativo semelhante transforma essa doutrina em um discurso vazio, desaguando numa das mais virulentas versões do pragmatismo jurídico, em que nem as normas devem ser respeitadas, nem há um rumo a ser tomado, abrindo-se espaço para o arbítrio. Isso se torna muito evidente quando seus autores permitem a utilização de argumentos de política e sua ponderação com princípios: não há uma ordem de valores prioritários para esses teóricos, mas apenas preferências que cambiam a depender do contexto fático e, principalmente, de quem interpreta o texto constitucional. Ao dissipar a densidade normativa das normas jurídicas e autorizar os juízes a decidirem com base em preferências pessoais, o Neoconstitucionalismo golpeia com intensidade o conceito de Estado de Direito, aproximando-o do fim.

Felizmente os próprios autores neoconstitucionais já estão começando a dar conta dos efeitos perniciosos que sua teoria tem causado para a nossa prática jurídica. Paulo Ricardo Schier (2005, p. 11 e 18), um dos precursores dessa corrente doutrinária, já reconhece que “o discurso (sedutor) da dogmática principialista (...) tem se prestado a relativizar todo e qualquer bem ou valor constitucionalmente protegido através dos princípios”, concluindo de maneira crítica que "todas as questões jurídicas vêm sido reportadas à dignidade da pessoa

\footnotetext{
${ }^{1}$ Luís Roberto Barroso é uma exceção a essa regra. Em recente artigo publicado em inglês, o autor procura dar contornos normativos ao princípio da dignidade humana para que sirva de parâmetro ao exercício da jurisdição constitucional. Cf. BARROSO, 2012.
} 
humana”. Daniel Sarmento (2007, p. 144) é ainda mais enfático ao afirmar que as teses do Neoconstitucionalismo abriram espaço para um “decisionismo travestido sob as vestes do politicamente correto, orgulhoso com seus jargões grandiloquentes e com sua retórica inflamada, mas sempre um decisionismo". E arremata: "Os princípios constitucionais, neste quadro, converteram-se em verdadeiras 'varinhas de condão': com eles o julgador de plantão consegue fazer tudo o que quiser”.

Não obstante as críticas, esses autores ainda não conseguiram conceitualizar o sentimento de perda que emerge quando os juízes utilizam uma das variadas teses de flexibilização das normas para decidir conforme suas preferências pessoais. Tanto Schier quanto Sarmento, sem abrir mão de seu instrumental teórico, procuram apelar para a prudência dos julgadores como forma de evitar que abusos sejam cometidos. Não se conseguiu identificar a raiz do problema. O que se argumentou no trabalho foi que esse sentimento de perda está intimamente ligado à violação dos valores subjacentes ao conceito de Estado de Direito. A partir do reconhecimento da dignidade da legislação e do Estado de Direito, muitas das angústias compartilhadas por esse autores podem ser mais bem compreendidas, possibilitando, a partir de uma interpretação construtiva, a adaptação de suas concepções jurídicas para albergar esses valores em seu âmago. Dado esse passo, contudo, haverá uma reviravolta no estudo do Neoconstitucionalismo. A centralidade da perspectiva do juiz como o agente da transformação social cederá espaço à revalorização da política democrática como principal fórum decisório e para o estudo do modo pelo qual as normas jurídicas advindas desse processo político passam a ser respeitadas e utilizadas como guias de conduta. Nesse dia será possível dizer que o Estado de Direito terá dado um fim ao Neoconstitucionalismo. 


\section{Referências}

ACKERMAN, Bruce. Nós, o Povo soberano: Fundamentos do Direito Constitucional. Tradução: Mauro Raposo de Mello. Belo Horizonte: Del Rey, 2006.

ACKERMAN, Bruce. The Living Constitution. 2006 Oliver Wendell Holmes Lecture. Harvard Law Review, v. 120, nº. 07, p. 1737-1812, maio de 2007.

AGRA, Walber de Moura. A Legitimação da Jurisdição Constitucional pelos Direitos Fundamentais. In: AGRA, Walber de Moura; CASTRO, Celso Luiz; TAVARES, André Ramos. Constitucionalismo: Os Desafios no Terceiro Milênio. Belo Horizonte: Fórum, 2008.

AGUIAR, Alexandre Magno Fernandes Moreira. O Estado de Direito e seus inimigos. Jus Navigandi, Teresina, ano $14, \mathrm{n}^{\circ}$. 2222, de $1^{\mathrm{o}}$ de agosto de 2009 . Disponível em: http://jus.com.br/revista/texto/13254. Acesso em: 20 set. 2012.

ALEINIKOFF, Alexander. Constitutional Law in the Age of Balancing. Yale Law Journal, vol. 96, nº. 5, p. 943-1005, abril de 1987.

ALEXY, Robert. Constitucionalismo Discursivo. Tradução: Luís Afonso Heck. $2^{\mathrm{a}}$ ed. rev. Porto Alegre: Livraria do Advogado Editora, 2008.

ALEXY, Robert. Teoria dos Direitos Fundamentais. Tradução: Virgílio Afonso da Silva. São Paulo: Malheiros, 2008.

ALEXY, Robert. Teoria da Argumentação Jurídica: A Teoria do Discurso Racional como Teoria da Fundamentação Jurídica. Tradução: Zilda Silva. São Paulo: Landy, 2008a.

ARGUELHES, Diego; LEAL, Fernando. Pragmatismo como [Meta] Teoria Normativa da Decisão Judicial: Caracterização, Estratégias e Implicações. In: SARMENTO, Daniel. Filosofia e Teoria Constitucional Contemporânea. Rio de Janeiro: Ed. Lumen Iures, 2009. ARGUELHES, Diego Werneck. Argumentação Consequencialista e Estado de Direito: Subsídios para uma Compatibilização. In: In: XIV Congresso Nacional do CONPEDI, realizado em Fortaleza nos dias 3, 4 e 5 de julho de 2005, publicado nos Anais do Congresso. Disponível http://www.conpedi.org.br/manaus/arquivos/Anais/Diego\%20Werneck\%20Arguelhes.pdf. Acesso em 13/07/2012.

AUSTIN, John. The Province of Jurisprudence Determined and the Uses of the Study of Jurisprudence. Indianapolis: Hackett Publishing Company, 1998.

ÁVILA, Humberto. Teoria dos Princípios: da Definição à Aplicação dos Princípios Jurídicos. São Paulo: Malheiros, 2008. 
ÁVILA, Humberto. "Neoconstitucionalismo": entre a "Ciência do Direito" e o "Direito da Ciência". In: SOUZA NETO, Cláudio; SARMENTO, Daniel; BINENBOJM, Gustavo. Vinte Anos da Constituição Federal de 1988. Rio de Janeiro: Ed. Lumen Juris, 2009.

BARROSO, Luís Roberto. Neoconstitucionalismo e Constitucionalização do Direito (O Triunfo tardio do direito constitucional no Brasil). In: PEREIRA NETO, Cláudio; SARMENTO, Daniel. A Constitucionalização do Direito: Fundamentos Teóricos e Aplicações Específicas. Rio de Janeiro: Lumen Iures, 2007.

BARROSO, Luís Roberto. A Reconstrução Democrática do Direito Público no Brasil. In: BARROSO, Luís Roberto. A Reconstrução Democrática do Direito Público no Brasil. Rio de Janeiro: Renovar, 2007a.

BARROSO, Luís Roberto. Fundamentos teóricos e filosóficos do novo direito constitucional brasileiro (pós-modernidade, teoria crítica e pós-positivismo). In: BARROSO, Luís Roberto. A Nova Interpretação Constitucional: Ponderação, Direitos Fundamentais e Relações Privadas. Rio de Janeiro, Renovar, 2008.

BARROSO, Luís Roberto. Vinte Anos da Constituição Brasileira de 1988: O Estado a que chegamos. Revista de Direito do Estado, v. 10, p. 25-66, 2008.

BARROSO, Luís Roberto. A Americanização do Direito Constitucional e seus Paradoxos: Teoria e Jurisprudência Constitucional no mundo contemporâneo. In: Filosofia e Teoria Constitucional Contemporânea. Rio de Janeiro: Ed. Lumen Iures, 2009.

BARROSO, Luís Roberto. Mutação Constitucional. In: MOREIRA, Eduardo; PUGLIESI, Marcio. 20 Anos da Constituição Brasileira. São Paulo: Saraiva, 2009a.

BARROSO, Luís Roberto. 'Here, There, and Everywhere': Human Dignity in Contemporary Law and in the Transnational Discourse. Boston College International and Comparative Law Review, vol. 35, nº. 2, p. 331-193, 2012.

BARROSO, Luís; BARCELLOS, Ana Paula. O começo da história. A nova interpretação constitucional e o papel dos princípios no direito brasileiro. In: BARROSO, Luís Roberto. A Nova Interpretação Constitucional: Ponderação, Direitos Fundamentais e Relações Privadas. Rio de Janeiro, Renovar, 2008.

BALKIN, Jack M. What "Brown" Teach us about Constitutional Theory. Virginia Law Review, vol. 90, $\mathrm{n}^{\mathrm{o}}$. 6 (50 Years of Brown v. Board of Education), p. 1537-1577, out. de 2004.

BALKIN, Jack. Constitutional Redemption: Political Faith on Unjust World. Cambridge: Harvard University Press, 2011.

BARCELOS, Ana Paula. Neoconstitucionalismo, Direitos Fundamentais e Políticas Públicas. In: QUARESMA, Regina; OLIVEIRA, Maria Lúcia; OLIVEIRA, Farlei Martins. Neoconstitucionalismo. Rio de Janeiro: Ed. Forense, 2009.

BASTOS, Celso. MARTINS, Ives. Comentários à Constituição do Brasil (Promulgada em 5 de outubro de 1988). Vol. 2. São Paulo: Saraiva, 1989. 
BEATTY, David. The Ultimate Rule of Law. Oxford: Oxford University Press, 2004.

BEDAQUE, José Roberto. Efetividade do Processo e Técnica Processual. $3^{\mathrm{a}}$ ed. São Paulo: Malheiros, 2010.

BEDNER, Adriaan. An Elementary Approach to the Rule of Law. Hague Journal on the Rule of Law, vol. 2, $\mathrm{n}^{\circ}$. 1, p. 48-79, março de 2010.

BERCOVICI, Gilberto. A Constituição Dirigente e a Crise da Teoria Constitucional. In: SOUZA NETO et. al. Teoria da Constituição: Estudos sobre o Lugar da Política no Direito Constitucional. Rio de Janeiro: Ed. Lumen Iures, 2003.

BERCOVICI, Gilberto. Constituição e Política: Uma relação difícil. Lua Nova, nº ${ }^{6}$, p. 524, 2004.

BERCOVICI, Gilberto. As Possibilidades de uma Teoria do Estado. Revista da Faculdade de Direito da UFMG, nº 49, p. 81-99, dezembro de 2006.

BICKEL, Alexander. The Least Dangerous Branch: The Supreme Court at the Bar of Politics. $2^{\mathrm{a}}$ ed. New Haven: Yale University Press, 1986.

BOROWSKI, Martin. The Beginnings of Germany's Federal Constitutional Court. Ratio Juris, Vol. 16, nº. 2, p. 155-186, Junho de 2003.

BRANCO, Paulo Gonet. Juízo de Ponderação na Jurisdição Constitucional. São Paulo: Saraiva, 2009.

BURRUS, Bernier. American Legal Realism. Howard Law Review, nº 8, p. 36-52, 1968.

CADEMARTORI, Luiz Henrique; DUARTE, Franciso Carlos. Hermenêutica e Argumentação Neoconstitucional. São Paulo: Atlas, 2010.

CAMBI, Eduardo. Neoconstitucionalismo e Neoprocessualismo: Direitos Fundamentais, políticas Públicas e Protagonismo Judiciário. São Paulo: Ed. Revista dos Tribunais, 2010.

CAMPOS, Carlos Alexandre. Moreira Alves v. Gilmar Mendes: a Evolução das Dimensões Metodológica e Processual do Ativismo Judicial do Supremo Tribunal Federal. In: FELLET, André; DE PAULA, Daniel; NOVELINO, Marcelo. As Novas Faces do Ativismo Judicial. Salvador: Ed. Juspodivm, 2011.

CANOTILHO, José Joaquim Gomes. Constituição Dirigente e Vinculação do Legislador: Contributo para a compreensão das Normas Constitucionais Programáticas. $2^{\mathrm{a}}$. ed. Coimbra: Coimbra Editora, 2001.

CAPELlETTI, Mauro; GARTH, Bryant. O Acesso à Justiça. Tradução de Ellen Gracie Northfleet. Sergio Antônio Fabris Editor. Porto Alegre, 1988.

CARBONELL, Miguel. Neoconstitucionalismo(s). Madrid: Ed. Trotta, 2003.

CARBONELL, Miguel. Nuevos tiempos para el Neoconstitucionalismo. In: CARBONELL, Miguel. Neoconstitucionalismo(s). Madrid: Trotta, 2003a. 
CARBONELL, Miguel. Teoría del Neconstitucionalismo: Ensayos Escoridos. Madrid: Ed. Trotta, 2007.

CARBONELL, Miguel. Neoconstitucionalismo: Elementos para uma Definición. In: MOREIRA, Eduardo; PUGLIESI, Marcio. 20 Anos da Constituição Brasileira. São Paulo: Saraiva, 2009.

CARBONELl, Miguel; JARAMILlO, Leonardo García. El Canon Neoconstitucional. Madrid, Trotta, 2010.

CINTRA, Antonio Carlos; GRINOVER, Ada Pellegrine; DINAMARCO, Cândido Rangel. Teoria Geral do Processo. $28^{\mathrm{a}}$ ed. São Paulo: Malheiros, 2012.

CHEMERINSKY, Erwin. Constitutional Law: principles and policies. $3^{\mathrm{a}}$ ed. New York: Aspen Publishers, 2006.

COELHO, Inocêncio. As idéias de Peter Häberle e a abertura da interpretação constitucional no direito brasileiro. Revista de Informação Legislativa, vol. 35, nº 137, p. 157-164, 1998.

COELHO, Inocêncio Mártires. Interpretação Constitucional. $3^{\text {a }}$ ed. rev. São Paulo: Saraiva, 2007.

COHEN-ELYIA, Moshe; PORAT, Iddo. American balancing and German proportionality: The historical origins. International Journal of Constitutional Law, vol. 8, $\mathrm{n}^{\circ} .2$, p. 263 286, abril de 2010.

COMANDUCCI, Paolo. Formas de (Neo)constitucionalismo: Um Análisis Metateórico. In: CARBONELL, Miguel. Neoconstitucionalismo(s). Madrid: Ed. Trotta, 2003.

COSTA, Alexandre; SOUSA JÚNIOR, José Geraldo. O Direito Achado na Rua: Uma Ideia em Movimento. In: COSTA, Alexandre et. al. O Direito Achado na Rua: Introdução Crítica ao Direito à Saúde. Brasília: CEAD/UnB, 2009.

COSTA, Alexandre; ASSIS, Vivian. O Direito Achado na Rua: Reflexões para uma Hermenêutica Crítica. In: XIX Congresso Nacional do CONPEDI, realizado em BrasíliaDF, nos dias 13, 14, 15 e 16 de outubro de 2010, publicado nos Anais do Congresso, p. 58965906. Disponível em http://gajop.org.br/justicacidada/wp-content/uploads/direito-achado-narua-hermeneutica-critica.pdf. Acesso em 6 de setembro de 2012.

CRAIG, Paul. Formal and Substantive Conceptions of the Rule of Law: An Analytical Framework. Public Law, nº. 21, p. 467-487, 1997.

CRUZ, Álvaro Ricardo. Uma nova alternativa para o Direito Brasileiro: O Procedimentalismo. In: SARMENTO, Daniel. Filosofia e Teoria Constitucional Contemporânea. Rio de Janeiro: Ed. Lumen Iures, 2009.

DAHL, Robert. Decision-Making in a Democracy: The Supreme Court as a National Policy Maker. Journal of Public Law, nº. 6, p. 279-295, 1957. 
DIAZ, Elías. Estado de Derecho y Sociedad Democratica. 6 ed. Madrid: Editorial Cuadernos para el Diálogo, 1975.

DIDIER JR., Fredie. Curso de Direito Processual Civil. Vol. 1. Salvador: Ed. Jus Podivm, 2009.

DIMOULIS, Dimitri; DUARTE, Écio. Teoria do Direito Neoconstitucional: Superação ou Reconstrução do Positivismo Jurídico? São Paulo: Método, 2008.

DIMOULIS, Dimitri. Neoconstitucionalismo e Moralismo Jurídico. In: SARMENTO, Daniel. Filosofia e Teoria Constitucional Contemporânea. Rio de Janeiro: Ed. Lumen Iures, 2009.

DUARTE, Écio Oto; POZZOLO, Susanna. Neoconstitucionalismo e Positivismo Jurídico. São Paulo: Landi, 2006.

DYZENHAUS, David. The Rule of Law as the Rule of Liberal Principle. In: RIPSTEIN, Arthur. Ronald Dworkin: Contemporary Philosophy in Focus. Cambridge: Cambridge University Press, 2007.

DWORKIN, Ronald. A Matter of Principle. Harvard University Press, 1985.

DWORKIN, Ronald. Law's Empire. Cambridge: Harvard University Press, 1986.

DWORKIN, Ronald. Freedom's Law: the Moral Reading of the American Constitution. Cambridge: Harvard University Press, 1996.

DWORKIN, Ronald. Do Values Conflict? A Hedhog's Approach. Arizona Law Review, vol. $43, n^{\circ} .2$, p. 251-259, 2001.

DWORKIN, Ronald. Levando os Direitos à Sério. Tradução de Nelson Boeira. São Paulo: Martins Fontes, 2002.

DWORKIN, Ronald. The Judge's New Role: Should Personal Convictions Count? Journal of International Criminal Justice, $n^{\circ}$. 1, p. 4-12, 2003.

DWORKIN, Ronald. The Practice of Integrity: Keynote Address. Acta Juridica, p. 1-17, 2004.

DWORKIN, Ronald. Justice in Robes. Cambridge: Harvard University Press, 2006.

DWORKIN, Ronald. Is is absurd to calculate human rights according to a cost-benefit analysis. The Guardian, 24 de maio de 2006a. Disponível em http://www.guardian.co.uk/commentisfree/2006/may/24/comment.politics. Acesso em 19/08/2012.

ELY, John Hart. Democracy and Distrust: A Theory of Judicial Review. Cambridge: Harvard University Press, 1980.

ESKRIDGE JR., William; FRICKEY, Philip. The Making of the Legal Process. Harvard Law Review, vol. 107, nº. 8, p. 2031-2055, junho de 1994. 
FACHIN, Luiz Edson. Direito civil e dignidade da pessoa humana: um diálogo constitucional contemporâneo. Revista Forense, v. 102, p. 113-126, 2006.

FERREIRA FILHO, Manoel Gonçalves. Estado de Direito e Constituição. $4^{\mathrm{a}}$ ed. rev. at. São Paulo: Saraiva, 2007.

FERREIRA FILHO, Manoel Gonçalves. Princípios Fundamentais do Direito Constitucional. São Paulo: Saraiva, 2009.

FERREIRA FILHO, Manoel Gonçalves. Curso de Direito Constitucional. $35^{\text {a }}$ ed. São Paulo: Saraiva, 2009a.

FININIS, John. Natural Law and Natural Rights. Oxford: Oxford University Press, 1980.

FRANCISCO, José Carlos. Estado Democrático de Direito, Políticas Públicas e Novos Modelos de Governanças Internacionais. In: HORBACH, Carlo et. al. Direito Constitucional, Estado de Direito e Democracia: Homenagem ao Prof. Manoel Gonçalves Ferreira Filho. São Paulo: Quartier Latin, 2011.

FULLER, Lon. The Morality of Law. ed. rev. New Haven: Yale University Press, 1969.

FUX, Luiz (coord.). Jurisdição Constitucional: Democracia e Direitos Fundamentais. Belo Horizonte: Fórum, 2012.

GREEN, Leslie. The Concept of Law Revisited. Michigan Law Review, nº 94, p. 16871717, maio de 1996.

GOLDSWORTHY, Jeffrey. Raz on Constitutional Interpretation. Law and Philosophy, vol. $22, \mathrm{n}^{\circ} .2$, p. 167-193, março de 2003.

GOLDSWORTHY, Jeffrey. Structural Judicial Review and the Objection from Democracy. University of Toronto Law Journal, vol. 60, $\mathrm{n}^{\mathrm{o}}$. 1, p. 137-154, 2010.

GUEST, Stephen. Ronald Dworkin. Stanford: Stanford University Press, 1991.

HABERMAS, Jurgen. Direito e Democracia: entre Faticidade e Validade. Vol. 1. Tradução de Flávio Beno Siebeneichler. Rio de Janeiro: Tempo Brasileiro, 2003.

HART, Henry; SACKS, Albert. The Legal Process: Basic Problems in the Making and Application of Law. Westbury: Foundation Press, Inc., 1994.

HART, Herbert L. A. The Concept of Law. 2a ed. Oxford: Oxford University Press, 1997.

HAYEK, Friedrich. The Constitution of Liberty. Chicago: University of Chicago Press, 1978.

HAYEK, Friedrich. Law, Legislation and Liberty: Volume 1, Rules and Order. Chicago: University of Chicago Press, 1978a.

HOLMES JR. Oliver Wendell. The Common Law. New Jersey: The Lawbook Exchange, 2005. 
HOLMES JR, Oliver Wendell. The Path of the Law. In: KAVANAGH, Aileen; OBERDIEK, John. Arguing About Law. New York: Routledge, 2009.

HORBACH, Carlos. A Nova Roupagem do Direito Constitucional: Neo-constitucionalismo, pós-positivismo e outros modismos. Revista dos Tribunais, v. 96, n. 859, p. 81-91, mai./2007.

JUSTEN FILHO, Marçal. O Direito das Agências Reguladoras Independentes. São Paulo: Dialética, 2002.

LOPES, José Reinaldo. Judiciário, democracia, política pública. Revista de Informação Legislativa, $n^{\circ} .31$, p. 255-265, mai./jul. 1994.

KEATING, Gregory C. Justifying Hercules: Ronald Dworkin and the Rule of Law. American Bar Foundation Research Journal, vol. 12, nº. 2/3, p. 525-535, 1987.

KELSEN, Hans. Jurisdição Constitucional. São Paulo: Martins Fontes 2003.

KELSEN, Hans. Pure Theory of Law. $2^{\text {a }}$ ed. rev. e ampl. Traduzido por Max Knight. Clark: The Lawbook Exchange, 2005.

KLARMAN, Michael J. Brown, Racial Change, and the Civil Rights Movement. Virginia Law Review, v. 80, $n^{\circ} .1$, p. 7-150.

MACCORMICK, Neil. Retórica e o Estado de Direito. Tradução de Conrado Hubner e Marcos Paulo Veríssimo. Rio de Janeiro: Elsevier, 2008.

MACINTYRE, Alastair. Theories of Natural Law in the Culture of Advanced Modernity. In: MCLEAN, Edward. Common Truth: New Perspectives on Natural Law. Wilmington: ISI Books, 1999.

MACKENNA, Marian. Franklin Roosevelt and the Great Constitutional War: The Court-packing Crisis of 1937. New York: Fordham University Press, 2002.

MADISON, James. Federalist $\mathbf{n}^{\mathbf{0}} \mathbf{1 0}$ - The Same Subject Continued: The Union as a Safeguard Against Domestic Faction and Insurrection. New York: New York Packet, 1787. Disponível em: http://thomas.loc.gov/home/histdox/fed_10.html Acesso em: 10 de junho de 2012.

MAIA, Antônio Cavalcanti. Nos Vinte Anos da Carta Cidadã: do Pós-positivismo ao Neoconstitucionalismo. In: SOUZA NETO, Cláudio; SARMENTO, Daniel; BINEMBOJM, Gustavo. Vinte Anos da Constituição Federal de 1988. Rio de Janeiro: Ed. Lumen Juris, 2009.

MAIA, Antônio Cavalcanti. As Transformações dos Sistemas Jurídicos Contemporâneos: Apontamentos Acerca do Neoconstitucionalismo. In: MOREIRA, Eduardo. Neoconstitucionalismo: A Invasão da Constituição. São Paulo: Método, 2008. 
MATIAS, João Luis. Neoconstitucionalismo e Direitos Fundamentais. São Paulo: Atlas, 2009.

MCWHINNEY, Edward. Judge Jerome Frank and Legal Realism: An Appraisal. New York Law Forum, vol. 3, nº. 2, p. 175-205, abril de 1957.

MENDES, João Ozório. EUA podem fazer escuta sem autorização judicial. Revista Consultor Jurídico, 8 de agosto de 2012. Disponível em: http://www.conjur.com.br/2012ago-08/governo-eua-escutas-autorizacao-judicial-tribunal. Acesso em: 09 de agosto de 2012.

MENDES, Gilmar Ferreira. Controle de Constitucionalidade: Hermenêutica Constitucional e Revisão de Fatos e Prognoses Legislativos pelo Órgão Judicial. Revista dos Tribunais, ${ }^{\circ}$. 766, p. 11-28, ago. 1999.

MENDES, Gilmar; COELHO, Inocêncio; BRANCO, Paulo. Curso de Direito Constitucional. São Paulo: Saraiva, 2007.

MENDES, Conrado Hubner. Controle de Constitucionalidade e Democracia. Rio de Janeiro: Elsevier, 2008.

MENDELSON, Wallace. The influence of James B. Thayer upon the Work of Holmes, Brandeis, and Frankfurter. Vanderbilt Law Review, nº. 31, p. 71-88, 1978.

MENDONÇA, Eduardo. A Constitucionalização da Política: Entre o Inevitável e o Excessivo. In: Revista da Faculdade de Direito da UERJ, vol. 1, $\mathrm{n}^{\circ}$. 18, 2010. Disponível em http://www.e-publicacoes.uerj.br/index.php/rfduerj/article/viewFile/1362/1150. Acesso em $\underline{20 / 06 / 12}$.

MOLLER, Max. Teoria Geral do Neoconstitucionalismo. São Paulo: Livraria do Advogado, 2011.

MOREIRA, Eduardo Ribeiro. Neoconstitucionalismo: A Invasão da Constituição. São Paulo: Ed. Método, 2009.

MOREIRA NETO, Diogo de Figueiredo. Estado, Economia e Neoconstitucionalismo - Notas sobre o Caso Brasileiro. In: QUARESMA, Regina; OLIVEIRA, Maria Lúcia; OLIVEIRA, Farlei Martins. Neoconstitucionalismo. Rio de Janeiro: Ed. Forense, 2009.

MORRISON, Wayne. Filosofia do Direito: Dos Gregos ao Pós-Modernismo. Tradução de Jefferson Luiz Camargo. São Paulo: Martins Fontes, 2006.

NEUBORNE, Burt. Judicial Review and Separation of Powers in France and in the United States. New York University Law Review, nº. 57, p. 363-442, junho de 1982.

NEUBORNE, Burt. Formalism, Functionalism, and the Separation of Powers. Harvard Journal of Law \& Public Policy, vol. 22, nº. 1, p. 45-52, Outono de 1998.

OLIVEIRA, Cláudio Ladeira. "Direito como Integridade" e "Ativismo Judicial": Algumas Considerações a partir de uma Decisão do Supremo Tribunal Federal. In: XVII Congresso Nacional do CONPEDI, realizado em Brasília-DF, nos dias 20, 21 e 22 de novembro de 
2008, publicado nos Anais do Congresso, p. 5444-5479. Disponível em http://www.conpedi.org.br/manaus/arquivos/anais/brasilia/04_835.pdf. Acesso em 20 de maio de 2012.

PEDRON, Flávio Quinuad. Comentáios sobre as Interpretações de Alexy e Dworkin. Revista do Centro de Estudos da Justiça Federal, nº. 30, p. 70-80, jul./set. de 2005.

PEDRA, Anderson. O Controle da Proporcionalidade dos Atos Legislativos. A Hermenêutica Constitucional como Instrumento. Belo Horizonte: Del Rey, 2006.

PENTEADO, Luciana. O “Quê" de Específico nas Cláusulas Gerais. Revista Direito GV, no. 1, vol. 1, p. 149-152, maio de 2005.

PEREIRA, Jane Reis. Os Imperativos de Razoabilidade e de Proporcionalidade. A Reconstrução Democrática do Direito Público no Brasil. Rio de Janeiro: Renovar, 2007.

PEREZ, Glória. Daniella Perez: Arquivos de um processo. Disponível em: www.gloriafperez.net. Acesso em: 22 de maio de 2012.

PERRY, Stephen. Hart's Methodological Positivism. In: COLEMAN, Jules. (ed) Hart's Postscript: Essays on the Postscript to the Concept of Law. Oxford: Oxford University Press, 2005.

POSNER, Richard. The Economics of Justice. Cambridge: Harvard University Press, 1981.

POSNER, Richard. The Problematics of Moral and Legal Theory. Cambridge: Harvard University Press, 2002.

POST, Robert. Constitutional Domains: Democracy, Community, Management. Cambridge: Harvard University Press, 1995.

POST, Robert; SIEGEL, Reva. Roe Rage: Democratic Constitutionalism and Backlash. Harvard Civil Rights-Civil Liberties Law Review, Cambridge, 2007. Disponível em http://papers.ssrn.com/sol3/papers.cfm?abstract_id=990968. Acesso em: 03 de junho de 2012.

POZZOLO, Susanna. Neoconstitucionalismo y Especifidad de la Interpretación Constitucional. Doxa, nº. 21, vol. II, p. 339-353, 1998.

PURCELL JR., Edward A. American Jurisprudence between the Warts: Legal Realism and the Crisis of Democratic Theory. The American Historical Review, vol. 75, $\mathrm{n}^{\circ}$. 2, p. 424446, dez. de 1969.

QUARESMA, Regina; OLIVEIRA, Maria Lúcia; OLIVEIRA, Farlei Martins. Neoconstitucionalismo. Rio de Janeiro: Ed. Forense, 2009.

RADBRUCH, Gustav. Statutory Lawlessness and Supra-Statutory Law. Tradução de Stanley Paulson. Oxford Journal of Legal Studies, vol. 26, nº 1, p. 1-11, 2006.

RAMOS, Elival da Silva. Ativismo Judicial: Parâmetros Dogmáticos. São Paulo: Saraiva, 2010. 
RAZ, Joseph. Authority, Law and Morality. The Monist, vol. 68, n. 3, p. 295-324, 1985.

RAZ, Joseph. Practical Reason and Norms. Oxford: Oxford University Press, 1999.

RAZ, Joseph. Between Authority and Interpretation. Oxford: Oxford University Press, 2009.

RAZ, Joseph. The Authority of Law: Essays on Law and Morality. $2^{\text {a }}$ ed. Oxford: Oxford University Press, 2009a.

RAWLS, John. Justiça como equidade: uma reformulação. São Paulo: Martins Fontes, 2003.

REALE JÚNIOR, Miguel. "Novo Código Penal é uma obscenidade. Não tem conserto". São Paulo: 2012. Revista Consultor Jurídico, 2 de setembro de 2012. Entrevista concedida a Pedro Canário e Marcos de Vasconcellos. Disponível em http://www.conjur.com.br/2012-set02/entrevista-miguel-reale-junior-decano-faculdade-direito-usp. Acesso em 02/09/2012.

RICHARDS, David. Rules, Policies and Neutral Principles: The Search for Legitimacy on Common Law and Constitutional Adjudication. Georgia Law Review, n ${ }^{\circ}$. 11, p. 1069-1114, 1977.

RICHARDS, David. Human Rights as the Unwritten Constitution: The Problem of Change and Stability in Constitutional Interpretation. University of Dayton Law Review, $\mathrm{n}^{\mathbf{0}}$ 4, p. 295-304, 1979.

RICHARDS, David. The Theory of Adjudication and the Task of the Great Justice. Cardozo Law Review, nº. 1, p. 171-218, 1979a.

RICHARDS, David. The Aims of Constitutional Theory. University of Dayton Law Review, no. 8, p. 723-744, 1983.

ROSENBERG, Gerald N. The Hollow Hope: Can Courts bring about Social Change? $2^{\mathrm{a}}$ ed. Chicago: Chicago University Press, 2008.

ROSENFELD, Michel. Hate Speech in Constitutional Jurisprudence: a Comparative Analysis. Cardozo Law Review, nº. 24, pg. 1523, 2002-2003.

RUBENFELD, Jed. Revolution by Judiciary: The Structure of American Constitutional Law. Cambridge: Harvard University Press, 2005.

SANCHÍS, Luis Prieto. Sobre o Neoconstitucionalismo y sus Implicaciones. In: Justicia Constitucional y Derechos Fundamentales. Madrid: Trotta, 2003.

SANTOS, Gustavo Ferreira. Neoconstitucionalismo, Poder Judiciário e Direitos Fundamentais. Curitiba: Juruá, 2011. 
SARMENTO, Daniel. Ubiquidade Constitucional: Os Dois Lados da Moeda. In: SOUZA NETO, Cláudio; SARMENTO, Daniel. A Constitucionalização do Direito: Fundamentos Teóricos e Aplicações Específicas. Rio de Janeiro: Lumen Iures, 2007.

SARMENTO, Daniel. O Neoconstitucionalismo no Brasil: Riscos e Possibilidade. In: SARMENTO, Daniel. Filosofia e Teoria Constitucional Contemporânea. Rio de Janeiro: Ed. Lumen Iures, 2009.

SARLET, Ingo Wolfgang. Neoconstitucionalismo e Influência dos Direitos Fundamentais no Direito Privado: uma Visão Panorâmica do Caso Brasileiro. In: QUARESMA, Regina; OLIVEIRA, Maria Lúcia; OLIVEIRA, Farlei Martins. Neoconstitucionalismo. Rio de Janeiro: Ed. Forense, 2009.

SARLET, Ingo; MARINONI, Luiz; MITIDIERO, Daniel. Curso de Direito Constitucional. São Paulo: Ed. Revista dos Tribunais, 2012.

SCALIA, Antonin. Common-Law Courts in a Civil-Law System: The Role of the United States Federal Courts in Interpreting the Constitution and Laws. In: A Matter of Intepretation: Federal Courts and the Law. New Jersey: Princeton University Press, 1997.

SCHAUER, Frederick. Playing by the Rules. A Philosophical Examination of Rule-Based Decision-Making in Law and in Life. Oxford: Oxford University Press, 1991.

SCHAUER, Frederick. Judicial Supremacy and the Modest Constitution. California Law Review, vol. 92, p. 1045-167, 2004.

SCHIER, Paulo Ricardo. Novos Desafios da Filtragem Constitucional no Momento do Neoconstitucionalismo. REDE - Revista Eletrônica de Direito do Estado, nº 4, 2005.

SCHMITT, Carl. Legalidad y legitimidad. Madrid: Aguilar, 1971.

SILVA, José Afonso. Curso de Direito Constitucional Positivo. 27 a ed. São Paulo: Malheiros, 2007.

SILVA, Virgílio Afonso. O Proporcional e o Razoável. Revista dos Tribunais, $\mathrm{n}^{\circ}$. 798, p. 23-50, 2002.

STEYN, Johan. Guantanamo Bay: The Legal Black Hole. 2003 Twenty-Seventh F.A. Mann Lecture. Disponível em http://www.statewatch.org/news/2003/nov/guantanamo.pdf. Acesso em: 03 de junho de 2012.

STONE, Adrienne. Judicial Review Without Rights: Some Problems for Democratic Legitimacy of Structural Judicial Review. Oxford Journal of Legal Studies, $n^{\circ}$. 28, vol. 1, p. $1-32,2008$.

STRECK, Lênio Luiz. Verdade e Consenso: Constituição, Hermenêutica e Teorias Discursivas. Da Possibilidade à necessidade de respostas corretas em Direito. Rio de Janeiro: Ed. Lumen Iures, 2007. 
STRECK, Lênio Luiz. A Incompatibilidade Paradigmática entre Positivismo e Neoconstitucionalismo. In: QUARESMA, Regina; OLIVEIRA, Maria Lúcia; OLIVEIRA, Farlei Martins. Neoconstitucionalismo. Rio de Janeiro: Ed. Forense, 2009.

STRECK, Lênio Luiz. A Crise Paradigmática do Direito no Contexto da Resistência Positivista ao (Neo)Constitucionalismo. In: SOUZA NETO, Cláudio; SARMENTO, Daniel; BINENBOJM, Gustavo. Vinte Anos da Constituição Federal de 1988. Rio de Janeiro: Ed. Lumen Juris, 2009a.

STRUCHINER, Noel. Porturas Interpretativas e Modelagem Institucional: A dignidade (contingente) do Formalismo Jurídico. In: SARMENTO, Daniel. Filosofia e Teoria Constitucional Contemporânea. Rio de Janeiro: Ed. Lumen Iures, 2009.

SULlIVAN, Kathleen; GUNTHER, Gerald. Constitutional Law. $6^{\text {a }}$ ed. New York: Foundation Press, 2007.

SUMMERS, Robert. A Formal Theory of the Rule of Law. Ratio Juris, vol. 6, no . 2, p. 127142, julho de 1993.

SUNSTEIN, Cass. Problems with Rules. California Law Review, vol. 83, nº. 4, p. 956-1026, 1995.

SUNSTEIN, Cass R. A Constitution of Many Minds: Why the Founding Document Doesn't Mean What It Meant Before. Princeton: Princeton University Press, 2009.

SWEET, Alec Stone; MATHEWS, Jud. Proportionality Balancing and Global Constitutionalism. Columbia Journal of Transnational Law, vol. 47, p. 73-165, 2008.

TAMANAHA, Brian Z. On The Rule of Law: History, Politics, Theory. Cambridge: Cambridge University Press, 2004.

TAMANAHA, Brian Z. Beyond the Formalist-Realist Divide: the Role of Politics in Judging. New Jersey: Princeton University Press, 2010.

THAYER, James B. The Origin and Scope of the American Doctrine of Constitutional Law. Harvard Law Review, vol. VII, nº. 3, p. 129-156, out. de 1893.

THOMPSON, Edward. Senhores e Caçadores. Rio de Janeiro: Paz e Terra, 1987.

TRIBE, Laurence H. The Puzzling Persistence of Process-Based Constitutional Theories. Yale Law Journal, vol. 89, nº. 6, p. 1063-1080, maio de 1980.

TSAKYRAKIS, Stavros. Proportionality: An Assault on Human Rights? International Journal of Constitutional Law, vol. 7, n'. 3, p. 468-493, julho de 2009.

ULHÔA; Raquel; BASILE, Juliano. "Prefiro falar a me omitir", diz Mendes. Valor Econômico, São Paulo, 15 abril 2010.

UNGER, Roberto Mangabeira. The Critical Legal Studies Movement. Harvard Law Review, vol. 96, no. 3, p. 561-675, 1983. 
UNGER, Roberto Mangabeira. O Direito e o Futuro da Democracia. Tradução de Caio Farah e Marcio Grandchamp. São Paulo: Boitempo: 2004.

VIEIRA, Oscar Vilhena. Supremocracia. In: SARMENTO, Daniel. Filosofia e Teoria Constitucional Contemporânea. Rio de Janeiro: Ed. Lumen Iures, 2009.

VIEIRA, Oscar Vilhena. A Desigualdade e a Subversão do Estado de Direito. In: SARMENTO, Daniel; IKAWA, Daniela; PIOVESAN, Flávia. Igualdade, Diferença e Direitos Humanos. Rio de Janeiro: Ed. Lumen Iures, 2008.

VALE, André Rufino. Aspectos do Neoconstitucionalismo. Revista Brasileira de Direito Constitucional, nº 09, p. 67-77, jan./jun. 2007.

ZAGREBELSKY, Gustavo. Ronald Dworkin's principle based constitutionalism: an Italian point of view. International Journal of Constitutional Law, Vol. 1, No. 4, p. 621-650, 2003.

ZAGREBELSKY, Gustavo. El Derecho Dúctil. $8^{\text {a }}$ ed. Madrid: Ed. Trotta, 2008.

ZAGREBELSKY, Gustavo. Estado Constitucional. In: HORBACH, Carlo et. al. Direito Constitucional, Estado de Direito e Democracia: Homenagem ao Prof. Manoel Gonçalves Ferreira Filho. São Paulo: Quartier Latin, 2011.

WALDRON, Jeremy. The Rule of Law in Contemporary Liberal Theory. Ratio Juris, vol. 2, $\mathrm{n}^{\circ}$. 1, p. 79-96, março de 1989.

WALDRON, Jeremy. A Right-Based Critique of Constitutional Rights. Oxford Journal of Legal Studies, vol. 13, no. 1, p. 18-51, 1993.

WALDRON, Jeremy. Fake Incommensurability: A Response to Professor Schauer. Hastings Law Journal, vol. 45, p. 813-824, 1993-1994.

WALDRON, Jeremy. Why Law - Efficacy, Freedom, or Fidelity? Law and Philosophy, vol. 13, no. 3, p. 259-284, 1994a.

WALDRON, Jeremy. Dirty Little Secret. Book Review of What Should Legal Analysis Become? Columbia Law Review, vol. 98, nº. 2, p. 510-330, 1998.

WALDRON, Jeremy. Law and Disagreement. Oxford: Oxford University Press, 1999.

WALDRON, Jeremy. Is the Rule of Law an Essentially Contested Concept (in Florida)? Law and Philosophy, vol. 21, $\mathrm{n}^{\mathrm{o}}$. 2, p. 137-164, março de 2002.

WALDRON, Jeremy. A Dignidade da Legislação. São Paulo: Martins Fontes, 2003.

WALDRON, Jeremy. The Rule of Law as a Theater of Debate. In: BURLEY, Justine. (ed.) Dworkin and his Critics. Malden: Blackwell Publishing, 2004. 
WALDRON, Jeremy. Normative (or Ethical) Positivism. In: COLEMAN, Jules. (ed.) Hart's Postscript: Essays on the Postscript of the Concept of Law. Oxford: Oxford University Press, 2005.

WALDRON, Jeremy. How Judges Should Judge. Book Review of Justice in Robes. The New York Review of Books, 10 de agosto de 2006.

WALDRON, Jeremy. Legislation and the Rule of Law. Legisprudence, vol. 1, $\mathrm{n}^{\mathrm{o}}$. 1, p. 91124, 2007.

WALDRON, Jeremy. The Concept and the Rule of Law. Georgia Law Review, vol. 43, $\mathrm{n}^{\circ}$. 1, p. 1-61, 2008.

WALDRON, Jeremy. Parliamentary Recklessness: Why we need to legislate more carefully. Auckland: Maxim Institute: 2008.

WALDRON, Jeremy. Do Judges Reason Morally? In: HUSCROFT, Grant. Expounding the Constitution: Essays in Constitutional Theory. Cambridge: Cambridge University Press, 2008b.

WALDRON, Jeremy. Can there be a Democratic Jurisprudence? Emory Law Journal, vol. 58, p. 675-712, 2008-2009.

WALDRON, Jeremy. A Essência da Oposição ao Judicial Review. In: BIGONHA, Antonio Carlos; MOREIRA, Luiz. Legitimidade da Jurisdição Constitucional. Rio de Janeiro: Ed. Lumen Jures, 2010.

WALDRON, Jeremy. The Rule of Law and the Importance of Procedure. New York University School of Law - Public Law \& Legal Theory Research Paper Series, out. de 2010a. Disponível em http://ssrn.com/abstract=1688491. Acesso em: 10 de janeiro de 2011.

WALDRON, Jeremy. Vagueness and the Guidance of Action. New York University School of Law - Public Law \& Legal Theory Research Paper Series, nov. de 2010b. Disponível em http://ssrn.com/abstract=1699963. Acesso em: 2 de setembro de 2012.

WALDRON, Jeremy. How Law Protects Dignity. New York University School of Law Public Law \& Legal Theory Research Paper Series, dec. de 2011. Disponível em http://ssrn.com/abstract=1973341. Acesso em: 10 de maio de 2012.

WALDRON, Jeremy. The Rule of Law and the Measure of Property. Cambridge: Cambridge University Press, 2012.

WECHSLER, Hebert. Towards Neutral Principles of Constitutional Law. Harvard Law Review, vol. 73, nº 1, p. 1-35, 1959-1960. 